Nevada

Environmental

Restoration

Project

Corrective Action Decision Document/ Closure Report for Corrective Action Unit 371: Johnnie Boy Crater and Pin Stripe Nevada Test Site, Nevada

Controlled Copy No::

Revision No.: 0

July 2010

Approved for public release; further dissemination unlimited.

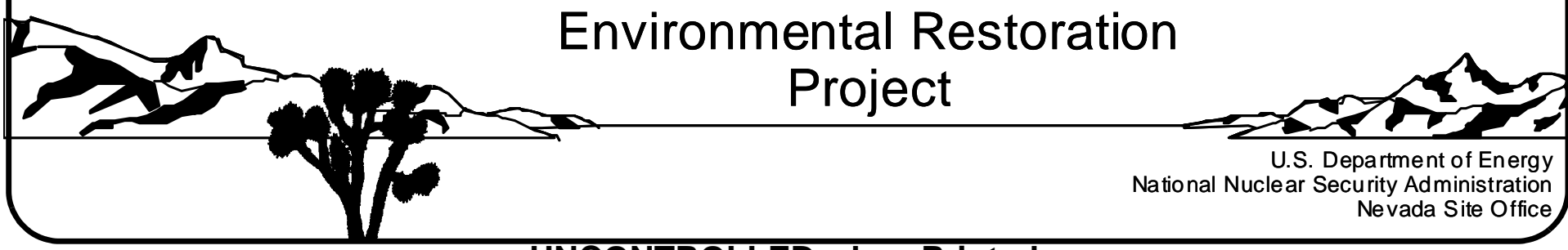


Available for sale to the public from:

U.S. Department of Commerce

National Technical Information Service

5301 Shawnee Road

Alexandria, VA 22312

Telephone: 800.553.6847

Fax: 703.605.6900

E-mail: orders@ntis.gov

Online Ordering: $\underline{h t t p: / / w w w . n t i s . g o v / h e l p / o r d e r m e t h o d s . a s p x ~}$

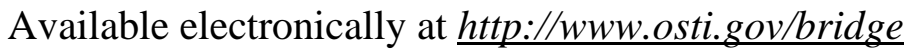

Available for a processing fee to U.S. Department of Energy and its contractors, in paper, from:

U.S. Department of Energy

Office of Scientific and Technical Information

P.O. Box 62

Oak Ridge, TN 37831-0062

Phone: 865.576.8401

Fax: 865.576.5728

Email: reports@adonis.osti.gov

Reference herein to any specific commercial product, process, or service by trade name, trademark, manufacturer, or otherwise, does not necessarily constitute or imply its endorsement, recommendation, or favoring by the United States Government or any agency thereof or its contractors or subcontractors. 


\title{
CORRECTIVE ACTION DECISION DOCUMENTI CLOSURE REPORT FOR CORRECTIVE ACTION UNIT 371: JOHNNIE BOY CRATER AND PIN STRIPE NEVADA TEST SITE, NEVADA
}

\author{
U.S. Department of Energy \\ National Nuclear Security Administration \\ Nevada Site Office \\ Las Vegas, Nevada
}

Controlled Copy No.:

Revision No.: 0

July 2010

Approved for public release; further dissemination unlimited.

Reviewed and determined to be UNCLASSIFIED.
Derivative Classifier: $\frac{\text { Joseph } P \text {. Johnston/NNES CO }}{\text { (Name/personal identifier and position title) }}$
Signature: $\frac{\text { /s/Joseph P. Johnston }}{\text { Date: } \quad 7 / 13 / 2010}$




\section{CORRECTIVE ACTION DECISION DOCUMENT/CLOSURE REPORT FOR CORRECTIVE ACTION UNIT 371: JOHNNIE BOY CRATER AND PIN STRIPE NEVADA TEST SITE, NEVADA}

Approved by: /s/Keven J. Cabble

Date: $7 / 13 / 2010$

Kevin J. Cabble

Federal Sub-Project Director

Soils Sub-Project

Approved by: /s/Robert F. Boehlecke

Date: $7 / 13 / 2010$

Robert F. Boehlecke

Federal Project Director

Environmental Restoration Project 


\section{Table of Contents}

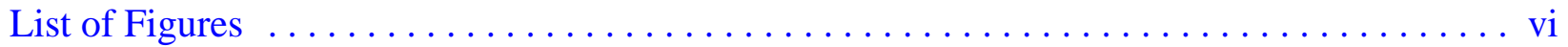

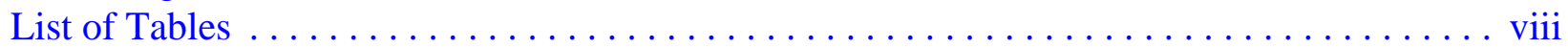

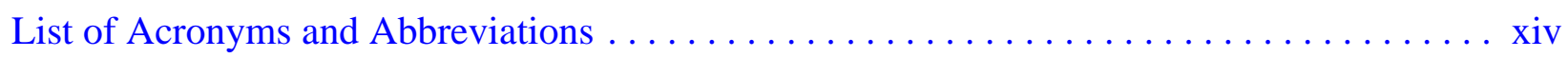

Executive Summary . . . . . . . . . . . . . . . . . . . . . . . . . . ES-1

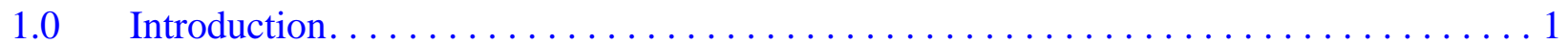

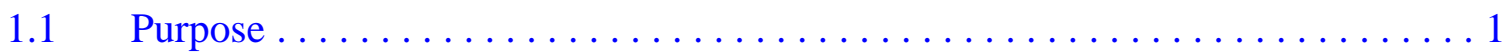

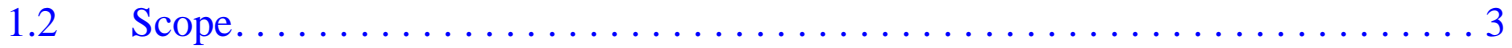

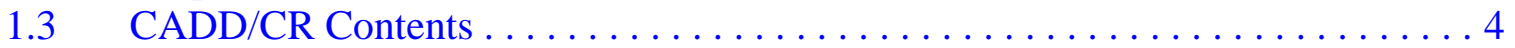

1.3.1 Applicable Programmatic Plans and Documents . . . . . . . . . . . 5

1.3.2 Data Quality Assessment Summary .................. 5

$2.0 \quad$ Corrective Action Investigation Summary $\ldots \ldots \ldots \ldots \ldots \ldots \ldots \ldots \ldots \ldots \ldots$

2.1 Investigation Activities . . . . . . . . . . . . . . . . . . . . 6

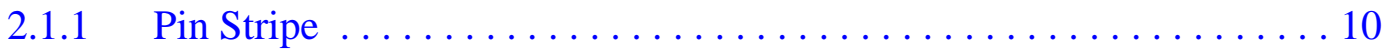

2.1.1.1 Description ...................... 10

2.1.1.2 Conceptual Site Model Validation . . . . . . . . . . 10

2.1 .2 Johnnie Boy . . . . . . . . . . . . . . . . . . 11

2.1.2.1 Description ............................. 11

2.1.2.2 Conceptual Site Model Validation . . . . . . . . . . 11

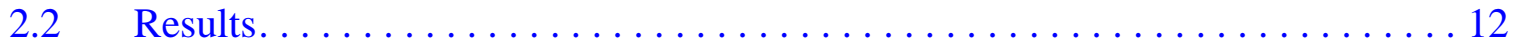

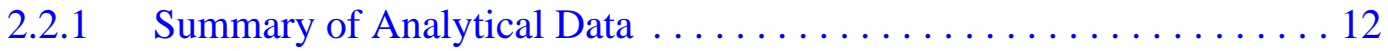

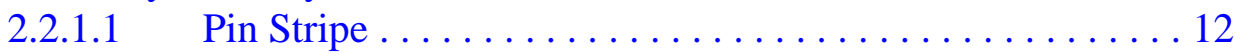

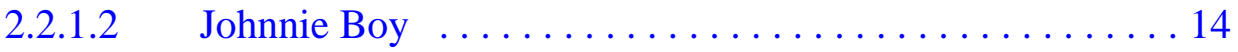

2.2.2 Data Assessment Summary . . . . . . . . . . . . . . . . . . . 19

2.3 Justification for No Further Action. . . . . . . . . . . . . . . . . . . 19

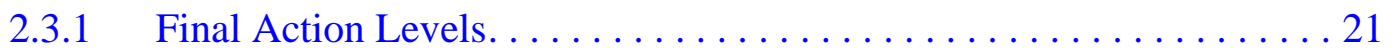

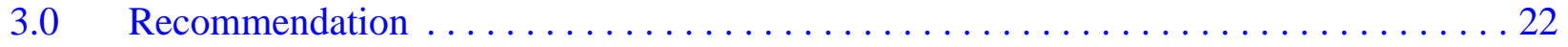

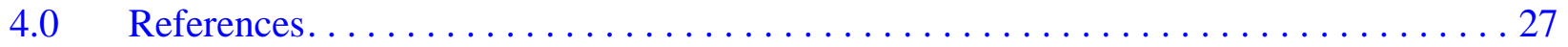

\section{Appendix A - Corrective Action Investigation Results}

A.1.0 Introduction. . . . . . . . . . . . . . . .

A.1.1 Project Objectives. . . . . . . . . . . . . . .

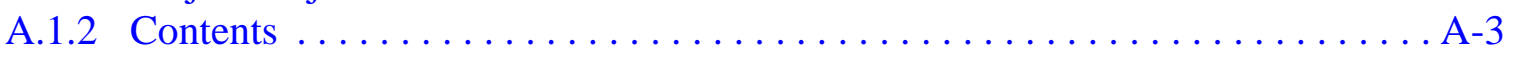

A.2.0 Investigation Overview $\ldots \ldots \ldots \ldots \ldots \ldots \ldots \ldots \ldots \ldots \ldots \ldots \ldots \ldots \ldots \ldots \ldots \ldots$

A.2.1 Sample Locations . ......................... A-5

A.2.2 Investigation Activities . . . . . . . . . . . . . . . . . . .

A.2.2.1 Radiological Surveys . ..................... A-6 


\section{Table of Contents (Continued)}

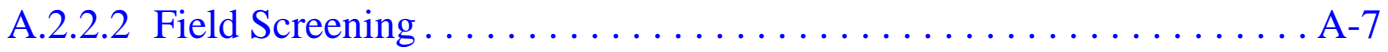

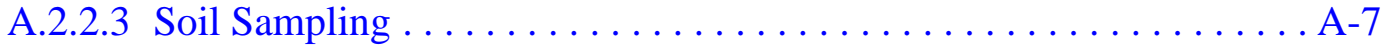

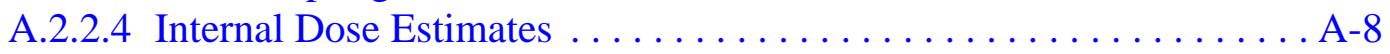

A.2.2.5 External Dose Measurements . . . . . . . . . . . . . . . . . A-8

A.2.3 Total Effective Dose . . . . . . . . . . . . . . . . . . . A -9

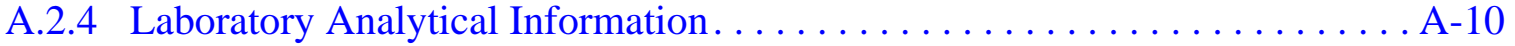

A.2.5 Comparison to Action Levels . . . . . . . . . . . . . . . . . A-11

A.3.0 CAS 11-23-05, Pin Stripe Contamination Area . . . . . . . . . . . . . . . . A-13

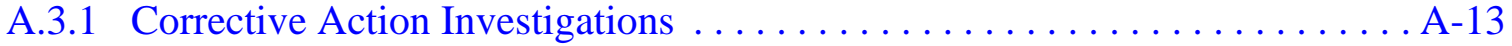

A.3.1.1 Visual Inspections. . . . . . . . . . . . . . . . . A-14

A.3.1.2 Radiological Surveys . . . . . . . . . . . . . . . . . . A-14

A.3.1.3 TLD Measurements . . . . . . . . . . . . . . . . A-16

A.3.1.4 Sample Collection. ........................ A-16

A.3.1.5 Deviations............................ A-18

A.3.2 Investigation Results. . . . . . . . . . . . . . . . . . A-18

A.3.2.1 External Radiological Dose Measurements . . . . . . . . . . . . . A-18

A.3.2.2 Internal Radiological Dose Estimations . . . . . . . . . . . . . . . . A-19

A.3.2.3 Total Effective Dose. . . . . . . . . . . . . . . . . . . A-20

A.3.2.4 Results for Other Release at Pin Stripe. . . . . . . . . . . . . . A-21

A.3.2.4.1 Gamma-Emitting Radionuclides .............. A-21

A.3.2.4.2 Isotopic Radionuclides . . . . . . . . . . . . A-23

A.3.3 Nature and Extent of Contamination . . . . . . . . . . . . . A-23

A.3.4 Revised Conceptual Site Model . . . . . . . . . . . . . . . . . A-27

A.4.0 CAS 18-45-01, U-18j-2 Crater (Johnnie Boy) . . . . . . . . . . . . . . . . . . . A-28

A.4.1 Corrective Action Investigation . . . . . . . . . . . . . . A-28

A.4.1.1 Visual Inspections. . . . . . . . . . . . . . . . . . . A-31

A.4.1.2 Radiological Surveys $\ldots \ldots \ldots \ldots \ldots \ldots \ldots \ldots \ldots \ldots \ldots \ldots \ldots$ A-31

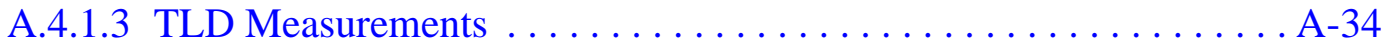

A.4.1.4 Sample Collection. ......................... A-36

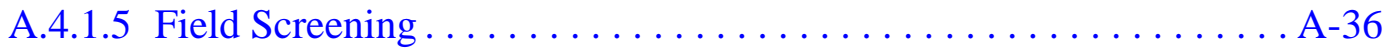

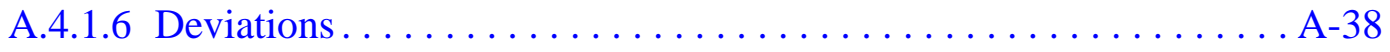

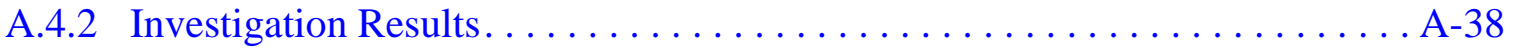

A.4.2.1 External Radiological Dose Measurements . . . . . . . . . . . . . . A-39

A.4.2.2 Internal Radiological Dose Estimations . . . . . . . . . . . . . . A-40

A.4.2.3 Total Effective Dose . . . . . . . . . . . . . . . . . . . . A-42

A.4.2.4 Results for Other Release at Johnnie Boy . . . . . . . . . . . . . . . A-44

A.4.2.4.1 Gamma-Emitting Radionuclides ............... A-46

A.4.2.4.2 Isotopic Radionuclides . . . . . . . . . . . . . A-46 


\section{Table of Contents (Continued)}

A.4.3 Nature and Extent of Contamination $\ldots \ldots \ldots \ldots \ldots \ldots \ldots \ldots \ldots \ldots$ A-46

A.4.4 Revised Conceptual Site Model ............................... A-54

A.5.0 Waste Management. . . . . . . . . . . . . . . . . . . . . . A-55

A.5.1 Investigation-Derived Waste $\ldots \ldots \ldots \ldots \ldots \ldots \ldots \ldots \ldots \ldots \ldots \ldots$ A-55

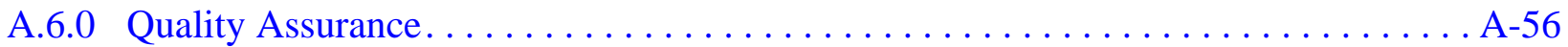

A.6.1 Data Validation. ................................. A-56

A.6.1.1 Tier I Evaluation . . . . . . . . . . . . . . . . . . . . A-56

A.6.1.2 Tier II Evaluation .............................. A-57

A.6.1.3 Tier III Evaluation $\ldots \ldots \ldots \ldots \ldots \ldots \ldots \ldots \ldots \ldots \ldots \ldots$. A-58

A.6.2 Field QC Samples . . . . . . . . . . . . . . . . . . . . . . . A-59

A.6.2.1 Laboratory QC Samples ..................... A-59

A.6.3 Field Nonconformances ............................. A-60

A.6.4 Laboratory Nonconformances $\ldots \ldots \ldots \ldots \ldots \ldots \ldots \ldots \ldots \ldots \ldots$. A-60

A.6.5 TLD Data Validation $\ldots \ldots \ldots \ldots \ldots \ldots \ldots \ldots \ldots \ldots \ldots \ldots \ldots \ldots \ldots \ldots$

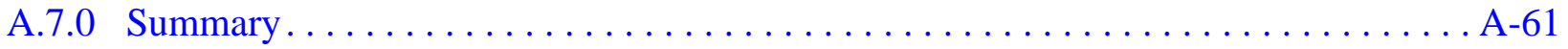

A.8.0 References................................... A-62

\section{Appendix B - Data Assessment}

B.1.0 Data Assessment..................................... B-1

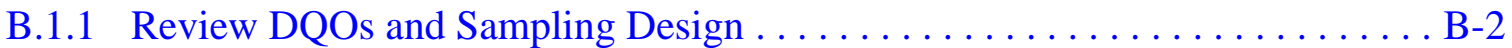

B.1.1.1 Decision I . . . . . . . . . . . . .

B.1.1.1.1 DQO Provisions To Limit False

Negative Decision Error ................. B-2

B.1.1.1.2 DQO Provisions To Limit False

Positive Decision Error .................. B-8

B.1.1.2 Decision II .............................. B-8

B.1.1.3 Sampling Design........................... B

B.1.2 Conduct a Preliminary Data Review $\ldots \ldots \ldots \ldots \ldots \ldots \ldots \ldots \ldots . . .6$

B.1.3 Select the Test and Identify Key Assumptions................. B-9

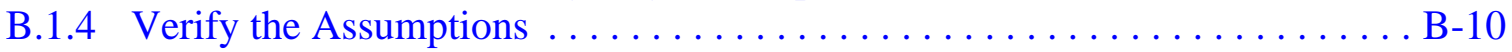

B.1.4.1 Other DQO Commitments ....................... B-11

B.1.5 Draw Conclusions from the Data $\ldots \ldots \ldots \ldots \ldots \ldots \ldots \ldots \ldots \ldots . . .11$

B.1.5.1 Decision Rules for Decision I. . . . . . . . . . . . . . B-11

B.1.5.2 Decision Rules for Decision II . . . . . . . . . . . . . . B-12

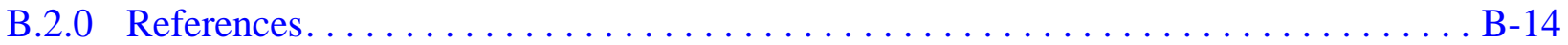




\section{Table of Contents (Continued)}

\section{Appendix C - Risk Assessment}

C.1.0 Risk Assessment. . . . . . . . . . . . . . . . . . . . . . .

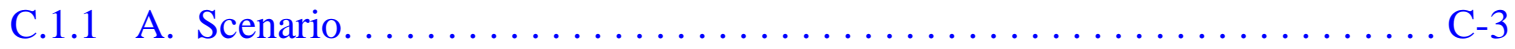

C.1.2 B. Site Assessment. . . . . . . . . . . . . . . . . . . . . . . C-3

C.1.3 C. Site Classification and Initial Response Action . . . . . . . . . . . . C-4

C.1.4 D. Development of Tier 1 Lookup Table of RBSLs . . . . . . . . . . . . . C-5

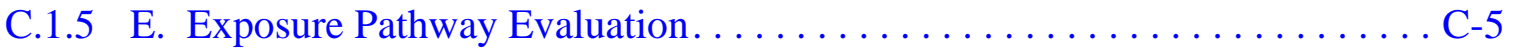

C.1.6 F. Comparison of Site Conditions with Tier 1 RBSLs . . . . . . . . . . . . . C-5

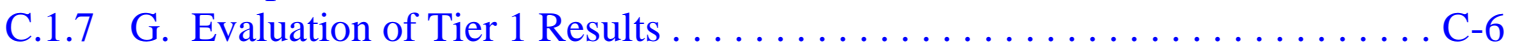

C.1.8 H. Tier 1 Remedial Action Evaluation $\ldots \ldots \ldots \ldots \ldots \ldots \ldots \ldots \ldots$. . . $\ldots \ldots$

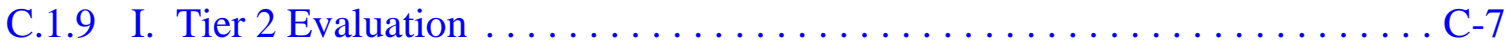

C.1.10 J. Development of Tier 2 Table of SSTLs . . . . . . . . . . . . . . C-7

C.1.11 K. Comparison of Site Conditions with Tier 2 Table SSTLs . . . . . . . . . . C-8

C.1.12 L. Tier 2 Remedial Action Evaluation ................... C-10

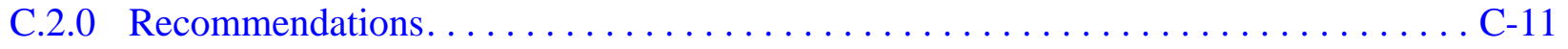

C.3.0 References................................. C-12

Attachment C-1 -Derivation of Residual Radioactive Material Guidelines

for Radionuclides in Soil at Corrective Action Unit (CAU) 371

Johnnie Boy Crater and Pin Stripe Nevada Test Site, Nevada

\section{Appendix D - Closure Activity Summary (Use Restriction)}

D.1.0 Closure Activity Summary $\ldots \ldots \ldots \ldots \ldots \ldots \ldots \ldots \ldots \ldots \ldots \ldots \ldots \ldots \ldots \ldots \ldots$

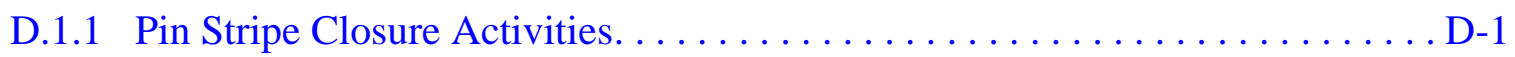

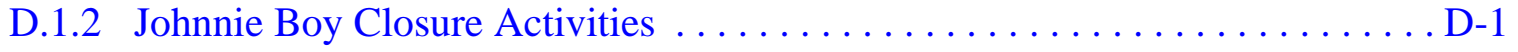

\section{Attachment D-1 - Use Restrictions}

\section{Appendix E - Evaluation of Corrective Action Alternatives}

E.1.0 Introduction. . . . . . . . . . .

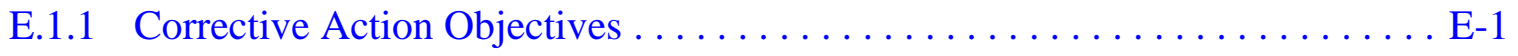

E.1.2 Screening Criteria . . . . . . . . . . . . . . . . . . . E

E.1.3 Corrective Action Standards. . . . . . . . . . . . . . . . . E-3

E.1.3.1 Remedy Selection Decision Factors . . . . . . . . . . . . E-3 


\section{Table of Contents (Continued)}

E.1.4 Development of Corrective Action Alternatives . . . . . . . . . . . . . E-5

E.1.4.1 Alternative 1 - No Further Action . . . . . . . . . . . . . . . E-5

E.1.4.2 Alternative 2 - Clean Closure. . . . . . . . . . . . . . . . . . E-6

E.1.4.3 Alternative 3 - Closure in Place.................. E-6

E.1.5 Evaluation and Comparison of Alternatives................. E-6

E.2.0 Recommended Alternative . . . . . . . . . . . . . . . . . . . . E-11

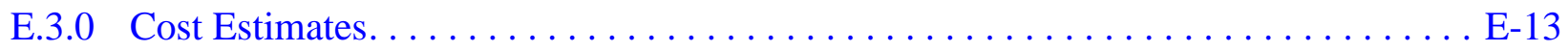

E.4.0 References.................................. E-14

\section{Appendix F - Composite Sample Plot Analytical Data}

F.1.0 Composite Sample Analytical Data for Pin Stripe . . . . . . . . . . . . . F-1

F.2.0 Composite Sample Analytical Data for Johnnie Boy . . . . . . . . . . . . . . . F-10

\section{Appendix G - Borehole and Sample Location Coordinates}

G.1.0 Sample Location Coordinates. . . . . . . . . . . . . . . . . . G-1

G.2.0 References................................... G-9

\section{Appendix H - Nevada Division of Environmental Protection Comments}




\section{List of Figures}

Number

Title

Page

1-1 CAU 371, CAS Location Map $\ldots \ldots \ldots \ldots \ldots \ldots \ldots \ldots \ldots \ldots \ldots \ldots \ldots \ldots \ldots \ldots$

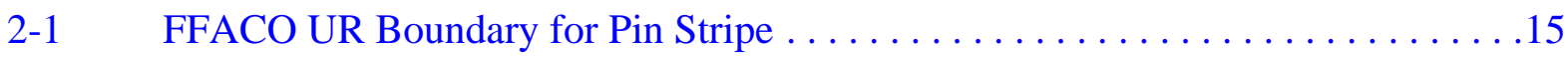

2-2 FFACO UR Boundary for Johnnie Boy $\ldots \ldots \ldots \ldots \ldots \ldots \ldots \ldots \ldots \ldots \ldots \ldots \ldots$

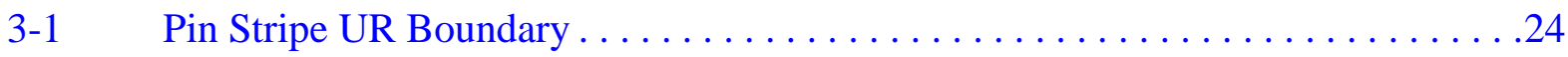

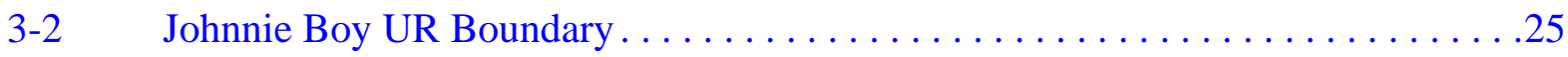

3-3 Johnnie Boy Administrative UR Boundary $\ldots \ldots \ldots \ldots \ldots \ldots \ldots \ldots \ldots . \ldots \ldots$

A.1-1 CAU 371, CAS Location Map $\ldots \ldots \ldots \ldots \ldots \ldots \ldots \ldots \ldots \ldots \ldots$ A-2

A.3-1 Gamma Walkover Surveys of Selected Locations at Pin Stripe. . . . . . . . . A-15

A.3-2 Pin Stripe Sample and TLD Locations ................... A-17

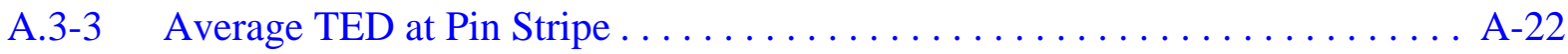

A.3-4 95\% UCL of the TED at Pin Stripe $\ldots \ldots \ldots \ldots \ldots \ldots \ldots \ldots \ldots \ldots . \ldots \ldots . . \ldots \ldots$

A.3-5 Pin Stripe UR Area $\ldots \ldots \ldots \ldots \ldots \ldots \ldots \ldots \ldots \ldots \ldots \ldots \ldots \ldots \ldots \ldots \ldots \ldots \ldots$

A.4-1 Features Identified during Visual Inspection of Johnnie Boy $\ldots \ldots \ldots \ldots$ A-32

A.4-2 Gamma Walkover Surveys of Selected Locations at Johnnie Boy . . . . . . . A-33

A.4-3 Johnnie Boy Sample and TLD Locations . . . . . . . . . . . . . A-37

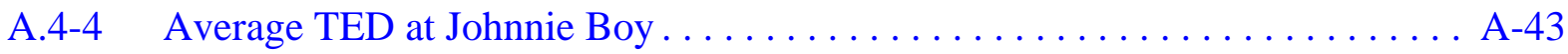

A.4-5 Values for the 95\% UCL of the TED at Johnnie Boy $\ldots \ldots \ldots \ldots \ldots \ldots$ A-45

A.4-6 Johnnie Boy UR Area ........................ A-49

A.4-7 Method 1: Correlation of the 95\% UCL of the TED to Gross Count Flyover Value at Johnnie Boy ............... A-50

A.4-8 Johnnie Boy Correlation of Gross Count Flyover Isopleth Values to 95\% UCL of TED and Distance along Vectors ............. A-51 


\section{List of Figures (Continued)}

Number

Title

Page

A.4-9 Method 2: Correlation of the 95\% UCL of the TED to Distance along Vectors at Johnnie Boy . . . . . . . . . . . . . . A-52

A.4-10 Johnnie Boy Administrative UR Area $\ldots \ldots \ldots \ldots \ldots \ldots \ldots \ldots \ldots \ldots$. . . . A-53

C.1-1 Risk-Based Corrective Action Decision Process . . . . . . . . . . . . . . . . . . . C-2 


\section{List of Tables}

Number

Title

Page

2-1 Pin Stripe TED at Sample Locations $(\mathrm{mrem} / \mathrm{yr}) \ldots \ldots \ldots \ldots \ldots \ldots \ldots \ldots$

2-2 Johnnie Boy TED at Sample Locations (mrem/yr) $\ldots \ldots \ldots \ldots \ldots \ldots$

2-3 Maximum Detected Sample Results for Other Releases at Johnnie Boy .... . . . 18

A.2-1 Laboratory Analyses and Methods, CAU 371 Investigation Samples . . . . . . . A-10

A.3-1 Samples Collected at Pin Stripe $\ldots \ldots \ldots \ldots \ldots \ldots \ldots \ldots \ldots \ldots \ldots \ldots \ldots \ldots \ldots \ldots \ldots$

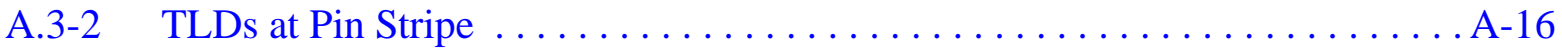

A.3-3 External Dose Measurements at Pin Stripe Sample Locations........... . A-19

A.3-4 Pin Stripe 95\% UCL External Dose for Each Exposure Scenario . . . . . . . . . A-19

A.3-5 Internal Dose Estimations at Pin Stripe Sample Plots (mrem/IA-yr) . . . . . . A-20

A.3-6 Pin Stripe Ratio of Average Internal Dose to External Dose

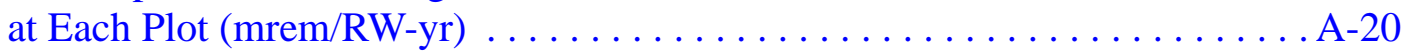

A.3-7 Pin Stripe Average Internal Dose for Each Exposure Scenario . . . . . . . . . A A-20

A.3-8 Pin Stripe 95\% UCL Internal Dose for Each Exposure Scenario. ......... . A-21

A.3-9 Pin Stripe TED at Sample Locations $(\mathrm{mrem} / \mathrm{yr}) \ldots \ldots \ldots \ldots \ldots \ldots \ldots$. . $\ldots \ldots \ldots$

A.3-10 Sample Results above MDCs at Pin Stripe Other Release . . . . . . . . . . . . A-25

A.4-1 Samples Collected at Johnnie Boy . . . . . . . . . . . . . . . . A-28

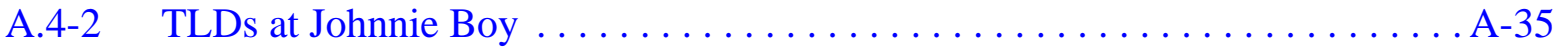

A.4-3 External Dose Measurements at Johnnie Boy (mrem/IA-yr) . . . . . . . . . . A-39

A.4-4 Johnnie Boy 95\% UCL External Dose for Each Exposure Scenario . . . . . . . . A-40

A.4-5 Internal Dose Estimations at Johnnie Boy Sample Plots (mrem/IA-yr) . . . . . A-41 


\section{List of Tables (Continued)}

Number

Title

Page

A.4-6 Johnnie Boy Ratio of Average Internal Dose to External Dose

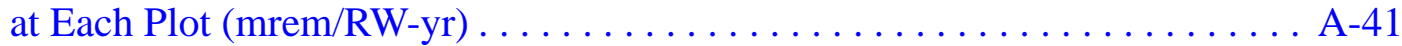

A.4-7 Johnnie Boy 95\% UCL Internal Dose for Each Exposure Scenario . . . . . . . A A-42

A.4-8 Johnnie Boy TED at Sample Locations $(\mathrm{mrem} / \mathrm{yr}) \ldots \ldots \ldots \ldots \ldots \ldots \ldots$. . A-44

A.4-9 Sample Results above MDCs at Johnnie Boy Other Releases . . . . . . . . . . A-47

B.1-1 Input Values and Determined Minimum Number of Samples

for CAU 371, Pin Stripe. . . . . . . . . . . . . . . . . . . B-4

B.1-2 Input Values and Determined Minimum Number of Samples

for CAU 371, Johnnie Boy $\ldots \ldots \ldots \ldots \ldots \ldots \ldots \ldots \ldots \ldots \ldots \ldots \ldots \ldots \ldots$

B.1-3 Precision Measurementsa $\ldots \ldots \ldots \ldots \ldots \ldots \ldots \ldots \ldots \ldots \ldots \ldots$

B.1-4 Key Assumptions................................ B-10

C.1-1 Locations Where TED Exceeds the PAL at CAU 371 (mrem/IA-yr) . . . . . . C C-6

C.1-2 Remote Work Area Scenario TED (mrem/RW-yr) . . . . . . . . . . . . . C-9

E.1-1 Evaluation of General Corrective Action Standards . . . . . . . . . . . . . . . . . .E-7

E.1-2 Evaluation of Remedy Selection Decision Factors . . . . . . . . . . . . E-8

F.1-1 Sample Results for Gamma-Emitting Radionuclides Detected above MDCs at Sample Plot AA . . . . . . . . . . . . . . . . F-1

F.1-2 Sample Results for Am-241 Detected above MDCs at Sample Plot AA . . . . . .F-2

F.1-3 Sample Results for Isotopes Detected above MDCs at Sample Plot AA . . . . . . F-2

F.1-4 Sample Results for Gamma-Emitting Radionuclides Detected above MDCs at Sample Plot AB . . . . . . . . . . . . . . . . F-3

F.1-5 Sample Results for Am-241 Detected above MDCs at Sample Plot AB .......F-3 


\section{List of Tables (Continued)}

Number

F.1-6 Sample Results for Isotopes Detected above MDCs at Sample Plot AB

F.1-7 Sample Results for Gamma-Emitting Radionuclides Detected above MDCs at Sample Plot AC . . . . . . . . . . . . . . . . . . . . F-4

F.1-8 Sample Results for Am-241 Detected above MDCs at Sample Plot AC . . . . . .F-5

F.1-9 Sample Results for Isotopes Detected above MDCs at Sample Plot AC . . . . . . F-5

F.1-10 Sample Results for Gamma-Emitting Radionuclides Detected above MDCs at Sample Plot AE . . . . . . . . . . . . . . . . . . . F-6

F.1-11 Sample Results for Am-241 Detected above MDCs at Sample Plot AE. ....... F-6

F.1-12 Sample Results for Isotopes Detected above MDCs at Sample Plot AE. . . . . . .F-7

F.1-13 Sample Results for Gamma-Emitting Radionuclides Detected above MDCs at Sample Plot AF . . . . . . . . . . . . . . . . . . F-7

F.1-14 Sample Results for Am-241 Detected above MDCs at Sample Plot AF........F-8

F.1-15 Sample Results for Isotopes Detected above MDCs at Sample Plot AF........F-8

F.2-1 Sample Results for Gamma-Emitting Radionuclides Detected above MDCs at Sample Plot BA .........................

F.2-2 Sample Results for Am-241 Detected above MDCs at Sample Plot BA . . . . . F-10

F.2-3 Sample Results for Isotopes Detected above MDCs at Sample Plot BA . . . . . F-11

F.2-4 Sample Results for Gamma-Emitting Radionuclides Detected above MDCs at Sample Plot BB . . . . . . . . . . . . . . . . ......F-11

F.2-5 Sample Results for Am-241 Detected above MDCs at Sample Plot BB....... F-11

F.2-6 Sample Results for Isotopes Detected above MDCs at Sample Plot BB. . . . . . F-12 


\section{List of Tables (Continued)}

Number

Title

Page

F.2-7 Sample Results for Gamma-Emitting Radionuclides Detected

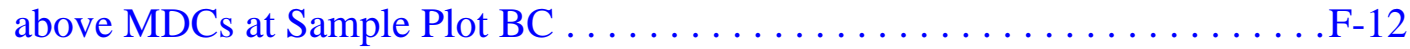

F.2-8 Sample Results for Am-241 Detected above MDCs at Sample Plot BC. . . . . .F-13

F.2-9 Sample Results for Isotopes Detected above MDCs at Sample Plot BC. . . . . . F-13

F.2-10 Sample Results for Gamma-Emitting Radionuclides Detected above MDCs at Sample Plot BD . . . . . . . . . . . . . . . . . . . . F-14

F.2-11 Sample Results for Am-241 Detected above MDCs at Sample Plot BD . . . . . F-14

F.2-12 Sample Results for Isotopes Detected above MDCs at Sample Plot BD . . . . . F-15

F.2-13 Sample Results for Gamma-Emitting Radionuclides Detected above MDCs at Sample Plot BE . . . . . . . . . . . . . . . . . . . F-15

F.2-14 Sample Results for Am-241 Detected above MDCs at Sample Plot BE. . . . . . F-16

F.2-15 Sample Results for Isotopes Detected above MDCs at Sample Plot BE.......F-16

F.2-16 Sample Results for Gamma-Emitting Radionuclides Detected above MDCs at Sample Plot BF .........................

F.2-17 Sample Results for Am-241 Detected above MDCs at Sample Plot BF . . . . . F-17

F.2-18 Sample Results for Isotopes Detected above MDCs at Sample Plot BF . . . . . F-18

F.2-19 Sample Results for Gamma-Emitting Radionuclides Detected above MDCs at Sample Plot BG . ........................ -18

F.2-20 Sample Results for Am-241 Detected above MDCs at Sample Plot BG . . . . . F-18

F.2-21 Sample Results for Isotopes Detected above MDCs at Sample Plot BG . . . . . F-19

F.2-22 Sample Results for Gamma-Emitting Radionuclides Detected above MDCs at Sample Plot BH . . . . . . . . . . . . . . . . . . . . . . F-19 


\section{List of Tables (Continued)}

Number

Title

Page

F.2-23 Sample Results for Am-241 Detected above MDCs at Sample Plot BH . . . . . . . . . . . . . . . . . . . . F-20

F.2-24 Sample Results for Isotopes Detected above MDCs

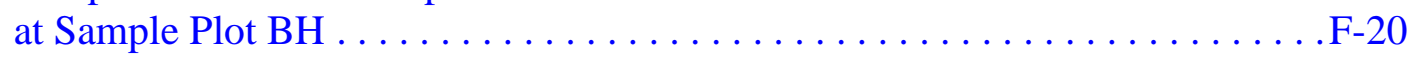

F.2-25 Sample Results for Gamma-Emitting Radionuclides Detected above MDCs at Sample Plot BJ. . . . . . . . . . . . . . . . . . . F-21

F.2-26 Sample Results for Am-241 Detected above MDCs at Sample Plot BJ . . . . . . . . . . . . . . . . . . . . . . F-21

F.2-27 Sample Results for Isotopes Detected above MDCs

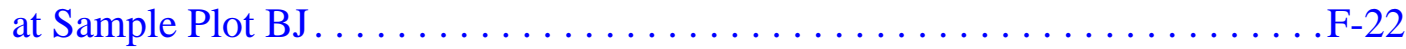

F.2-28 Sample Results for Gamma-Emitting Radionuclides Detected above MDCs at Sample Plot BK . . . . . . . . . . . . . . . . . . . F-22

F.2-29 Sample Results for Am-241 Detected above MDCs at Sample Plot BK . . . . . F-23

F.2-30 Sample Results for Isotopes Detected above MDCs at Sample Plot BK . . . . . F-23

F.2-31 Sample Results for Gamma-Emitting Radionuclides Detected above MDCs at Sample Plot BL . . . . . . . . . . . . . . . . . F-24

F.2-32 Sample Results for Am-241 Detected above MDCs at Sample Plot BL. . . . . . F-24

F.2-33 Sample Results for Isotopes Detected above MDCs at Sample Plot BL . . . . . . F-25

F.2-34 Sample Results for Gamma-Emitting Radionuclides Detected above MDCs at Sample Plot BM. . . . . . . . . . . . . . . . . . F-25

F.2-35 Sample Results for Am-241 Detected above MDCs at Sample Plot BM . . . . . F-26

F.2-36 Sample Results for Isotopes Detected above MDCs at Sample Plot BM . . . . . F-26

F.2-37 Sample Results for Gamma-Emitting Radionuclides Detected above MDCs at Sample Plot BN . . . . . . . . . . . . . . . F-27 


\section{List of Tables (Continued)}

Number

Title

Page

F.2-38 Sample Results for Isotopes Detected above MDCs at Sample Plot BN . . . . . F-27

F.2-39 Sample Results for Gamma-Emitting Radionuclides Detected above MDCs at Sample Plot BP . . . . . . . . . . . . . . . . . . . . F-28

F.2-40 Sample Results for Am-241 Detected above MDCs

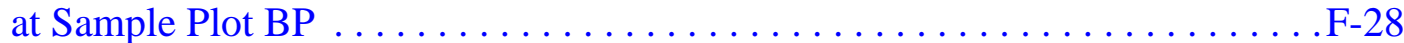

F.2-41 Sample Results for Isotopes Detected above MDCs at Sample Plot BP ................................... 29

G.1-1 Sample Plot/Location Coordinates for Pin Stripe $\ldots \ldots \ldots \ldots \ldots \ldots$ G-1

G.1-2 Sample Plot/Location Coordinates for Johnnie Boy . . . . . . . . . . . . G-1

G.1-3 Sample Plot Location Distance (Pin Stripe) in Meters $\ldots \ldots \ldots \ldots \ldots \ldots$ G-3

G.1-4 Sample Plot Location Distance (Johnnie Boy) in Meters . . . . . . . . . . . . G-5 


\section{List of Acronyms and Abbreviations}

Ac

ALARA

Am

ANPR

ASTM

bgs

BMP

CAA

CADD

CAI

CAIP

CAS

CAU

CED

CFR

CLP

$\mathrm{cm}$

Co

COC

COPC

cps

CR

Cs

CSM

$\mathrm{CZ}$

day/yr
Actinium

As low as reasonably achievable

Americium

Advance Notice of Proposed Rulemaking

American Society for Testing and Materials

Below ground surface

Best management practice

Corrective action alternative

Corrective action decision document

Corrective action investigation

Corrective action investigation plan

Corrective action site

Corrective action unit

Committed effective dose

Code of Federal Regulations

Contract Laboratory Program

Centimeter

Cobalt

Contaminant of concern

Contaminant of potential concern

Counts per second

Closure report

Cesium

Conceptual site model

Contamination zone

Days per year 


\section{List of Acronyms and Abbreviations (Continued)}

\begin{tabular}{|c|c|}
\hline DOE & U.S. Department of Energy \\
\hline DQA & Data quality assessment \\
\hline DQI & Data quality indicator \\
\hline DQO & Data quality objective \\
\hline ED & Effective dose \\
\hline EML & Environmental Measurements Laboratory \\
\hline EPA & U.S. Environmental Protection Agency \\
\hline $\mathrm{Eu}$ & Europium \\
\hline FAL & Final action level \\
\hline FD & Field duplicate \\
\hline FFACO & Federal Facility Agreement and Consent Order \\
\hline FSR & Field-screening result \\
\hline $\mathrm{ft}$ & Foot \\
\hline $\mathrm{g} / \mathrm{yr}$ & Grams per year \\
\hline GPS & Global Positioning System \\
\hline GWS & Gamma walkover survey \\
\hline GZ & Ground zero \\
\hline HASL & Health and Safety Laboratory \\
\hline $\mathrm{hr} /$ day & Hours per day \\
\hline $\mathrm{hr} / \mathrm{yr}$ & Hours per year \\
\hline ID & Identification \\
\hline IDW & Investigation-derived waste \\
\hline in. & Inch \\
\hline LCS & Laboratory control sample \\
\hline $\mathrm{m}$ & Meter \\
\hline $\mathrm{m}^{2}$ & Square meter \\
\hline
\end{tabular}




\section{List of Acronyms and Abbreviations (Continued)}

\begin{tabular}{|c|c|}
\hline $\mathrm{m} / \mathrm{yr}$ & Meters per year \\
\hline MDC & Minimum detectable concentration \\
\hline mg/day & Milligrams per day \\
\hline $\mathrm{mg} / \mathrm{kg}$ & Milligrams per kilogram \\
\hline $\mathrm{mi}$ & Mile \\
\hline $\mathrm{M} \& \mathrm{O}$ & Management and operating \\
\hline mrem & Millirem \\
\hline mrem/IA-yr & Millirem per Industrial Area year \\
\hline mrem/OU-yr & Millirem per Occasional Use Area year \\
\hline mrem/RW-yr & Millirem per Remote Work Area year \\
\hline mrem/yr & Millirem per year \\
\hline N/A & Not applicable \\
\hline NAC & Nevada Administrative Code \\
\hline NAD & North American Datum \\
\hline NDEP & Nevada Division of Environmental Protection \\
\hline NIOSH & National Institute for Occupational Safety and Health \\
\hline NIST & National Institute of Standards and Technology \\
\hline NNSA/NSO & $\begin{array}{l}\text { U.S. Department of Energy, National Nuclear Security Administration } \\
\text { Nevada Site Office }\end{array}$ \\
\hline NTS & Nevada Test Site \\
\hline PAL & Preliminary action level \\
\hline $\mathrm{Pb}$ & Lead \\
\hline $\mathrm{pCi} / \mathrm{g}$ & Picocuries per gram \\
\hline PPE & Personal protective equipment \\
\hline $\mathrm{Pu}$ & Plutonium \\
\hline QA & Quality assurance \\
\hline QAPP & Quality Assurance Project Plan \\
\hline
\end{tabular}




\section{List of Acronyms and Abbreviations (Continued)}

\begin{tabular}{|c|c|}
\hline QC & Quality control \\
\hline RBCA & Risk-based corrective action \\
\hline RBSL & Risk-based screening level \\
\hline RCRA & Resource Conservation and Recovery Act \\
\hline RESRAD & Residual Radioactive \\
\hline RIDP & Radionuclide Inventory and Distribution Program \\
\hline RPD & Relative percent difference \\
\hline RRMG & Residual radioactive material guideline \\
\hline RWMS & Radioactive Waste Management Site \\
\hline SCL & Sample collection log \\
\hline SDG & Sample delivery group \\
\hline SoF & Sum of the fractions \\
\hline $\mathrm{Sr}$ & Strontium \\
\hline SSTL & Site-specific target level \\
\hline TED & Total effective dose \\
\hline Th & Thorium \\
\hline $\mathrm{Tl}$ & Thallium \\
\hline TLD & Thermoluminescent dosimeter \\
\hline $\mathrm{U}$ & Uranium \\
\hline UCL & Upper confidence limit \\
\hline UR & Use restriction \\
\hline UTM & Universal Transverse Mercator \\
\hline VSP & Visual Sample Plan \\
\hline $\mathrm{yd}^{3}$ & Cubic yard \\
\hline$\mu \mathrm{R} / \mathrm{hr}$ & Microroentgens per hour \\
\hline
\end{tabular}




\section{Executive Summary}

This Corrective Action Decision Document/Closure Report has been prepared for Corrective Action Unit 371, Johnnie Boy Crater and Pin Stripe, located within Areas 11 and 18 at the Nevada Test Site, Nevada, in accordance with the Federal Facility Agreement and Consent Order (FFACO). Corrective Action Unit (CAU) 371 comprises two corrective action sites (CASs):

- 11-23-05, Pin Stripe Contamination Area

- 18-45-01, U-18j-2 Crater (Johnnie Boy)

The purpose of this Corrective Action Decision Document/Closure Report is to provide justification and documentation supporting the recommendation that no further corrective action is needed for CAU 371 based on the implementation of corrective actions. The corrective action of closure in place with administrative controls was implemented at both CASs. Corrective action investigation (CAI) activities were performed from January 8, 2009, through February 16, 2010, as set forth in the Corrective Action Investigation Plan for Corrective Action Unit 371: Johnnie Boy Crater and Pin Stripe.

The approach for the CAI was divided into two facets: investigation of the primary release of radionuclides and investigation of other releases (migration in washes and chemical releases). The purpose of the CAI was to fulfill data needs as defined during the data quality objective (DQO) process. The CAU 371 dataset of investigation results was evaluated based on the data quality indicator parameters. This evaluation demonstrated the dataset is acceptable for use in fulfilling the DQO data needs.

Analytes detected during the CAI were evaluated against final action levels (FALs) established in this document. Radiological doses exceeding the FAL of 25 millirem per year were not found to be present in the surface soil. However, it was assumed that radionuclides are present in subsurface media within the Johnnie Boy crater and the fissure at Pin Stripe. Due to the assumption of radiological dose exceeding the FAL, corrective actions were undertaken that consist of implementing a use restriction and posting warning signs at each site. These use restrictions were recorded in the FFACO database; the U.S. Department of Energy, National Nuclear Security Administration Nevada Site Office (NNSA/NSO) Facility Information Management System; and the NNSA/NSO CAU/CAS files. 
Therefore, NNSA/NSO provides the following recommendations:

- $\quad$ No further corrective actions are necessary for CAU 371.

- A Notice of Completion to NNSA/NSO is requested from the Nevada Division of Environmental Protection for closure of CAU 371.

- Corrective Action Unit 371 should be moved from Appendix III to Appendix IV of the FFACO. 


\subsection{Introduction}

This Corrective Action Decision Document (CADD)/Closure Report (CR) presents information supporting closure of Corrective Action Unit (CAU) 371, Johnnie Boy Crater and Pin Stripe, located at the Nevada Test Site (NTS), Nevada. The corrective actions described in this document were implemented in accordance with the Federal Facility Agreement and Consent Order (FFACO) that was agreed to by the State of Nevada; U.S. Department of Energy (DOE), Environmental Management; U.S. Department of Defense; and DOE, Legacy Management (FFACO, 1996; as amended March 2010). The NTS is located approximately 65 miles (mi) northwest of Las Vegas, Nevada.

Corrective Action Unit 371 comprises the two corrective action sites (CASs) shown on Figure 1-1 and listed below:

- 11-23-05, Pin Stripe Contamination Area

- $\quad$ 18-45-01, U-18j-2 Crater (Johnnie Boy)

A detailed discussion of the history of this CAU is presented in the Corrective Action Investigation Plan (CAIP) for Corrective Action Unit 371: Johnnie Boy Crater and Pin Stripe (NNSA/NSO, 2009).

\subsection{Purpose}

This document provides documentation and justification for the closure of CAU 371 without further corrective action. This justification is based on process knowledge, the results of the investigative activities conducted in accordance with the CAIP, and implementation of the corrective action of closure in place. The CAIP provides information relating to site history as well as the scope and planning of the investigation. Therefore, this information will not be repeated in this document.

Corrective Action Unit 371 consists of two inactive sites on the NTS. Corrective Action Site 11-23-05 (referred to as Pin Stripe in this document) is located in Area 11 and consists of a release of radioactive material from the underground Pin Stripe (U11b) weapons-effects test that vented to the surface through a fissure. This release resulted in surface soil contamination and 


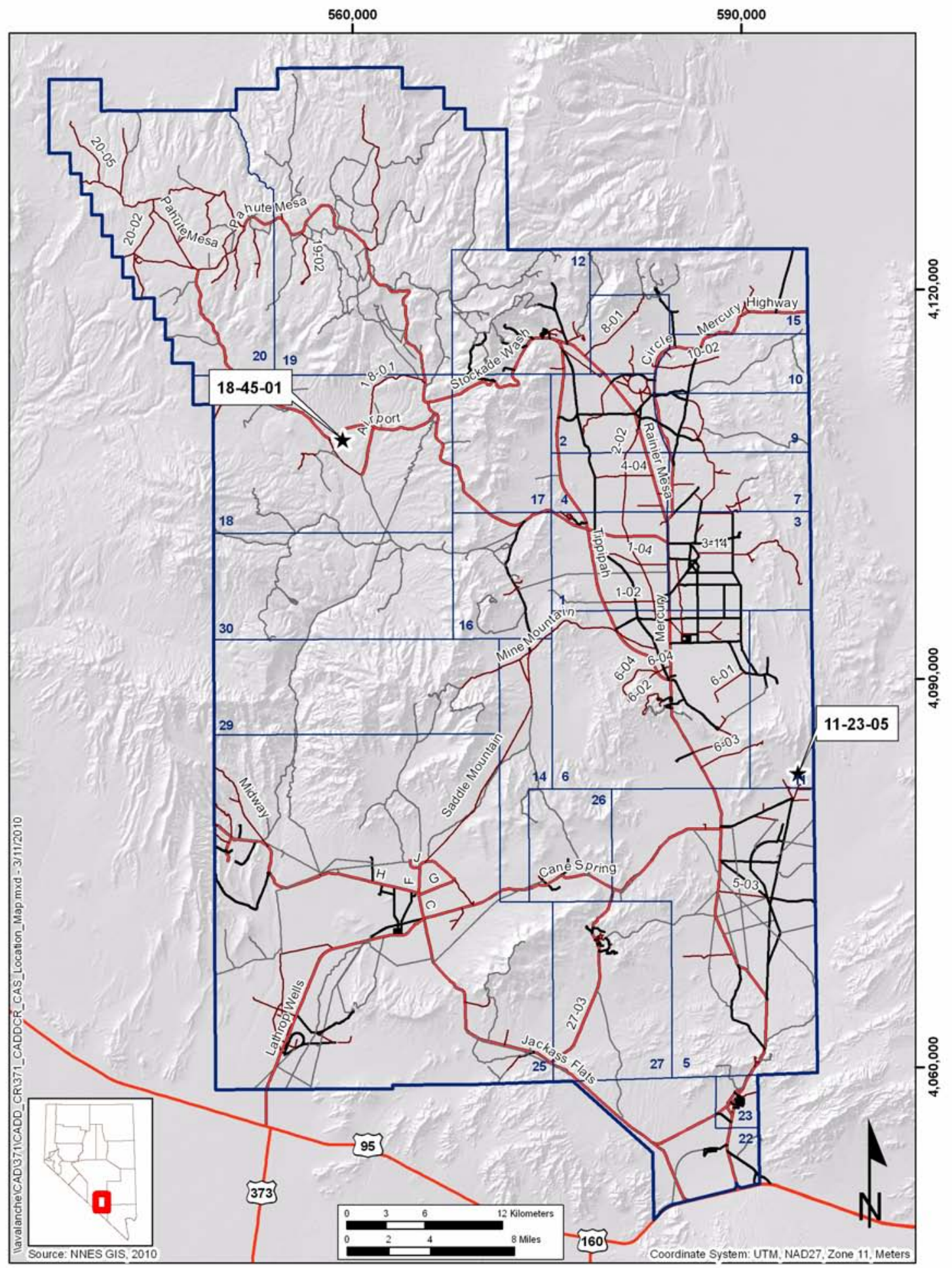

Figure 1-1

CAU 371, CAS Location Map 
contamination in the subsurface fissure. A subsidence crater formed following the test, and testing-related debris is present throughout the site.

Corrective Action Site 18-45-01 (referred to as Johnnie Boy in this document) is located in Area 18 and consists of a release of radioactive material from the near-surface Johnnie Boy (U-18j-2) weapons-effects test. This release resulted in the contamination of material in the resulting crater, in the ejecta piles surrounding the crater, and on the soil surface from atmospheric deposition of radioactive material. Test-related debris and equipment are present throughout the site.

\subsection{Scope}

The corrective actions for CAU 371 were completed by:

- Demonstrating through environmental soil and thermoluminescent dosimeter (TLD) sample analytical results that contaminants of concern (COCs) do not exist in surface media at either CAS.

- Assuming that subsurface COCs exist in the crater at Johnnie Boy and the fissure at Pin Stripe.

- Implementing use restrictions (URs) to protect future workers from inadvertent contact with the COCs.

The scope of activities to complete the closure of CAU 371 included the following:

- Performing radiological surveys

- Collecting environmental samples for laboratory analysis

- Collecting quality control (QC) samples

- Placing, collecting, and analyzing TLDs

- Evaluating corrective action alternatives (CAAs)

- Implementing the selected corrective actions

- Documenting and justifying closure activities

- Performing best management practices (BMPs) 


\section{$1.3 \quad C A D D / C R$ Contents}

This document is divided into the following sections and appendices:

Section 1.0 - Introduction: Summarizes the document purpose, scope, and contents.

Section 2.0 - Corrective Action Investigation (CAI) Summary: Summarizes the investigation field activities and the results of the investigation, and justifies that no further corrective action is needed.

Section 3.0 - Recommendation: Provides the basis for requesting that the CAU be moved from Appendix III to Appendix IV of the FFACO.

Section 4.0 - References: Provides a list of all referenced documents used in the preparation of this CADD/CR.

Appendix A -Corrective Action Investigation Results: Provides a description of the project objectives, field investigation and sampling activities, investigation results, waste management, and quality assurance (QA). Sections A.3.0 and A.4.0 provide specific information regarding field activities, sampling methods, and laboratory analytical results from the investigation.

Appendix B -Data Assessment: Provides a data quality assessment (DQA) that reconciles data quality objective (DQO) assumptions and requirements to the investigation results.

Appendix C -Risk Assessment: Presents an evaluation of risk associated with the establishment of final action levels (FALs).

Appendix D -Closure Activity Summary: Provides details on the completed closure activities, and includes the required verification activities and supporting documentation.

Appendix E-Evaluation of Corrective Action Alternatives: Provides a discussion of the results of the CAI, the alternatives considered, and the rationale for the recommended alternative. 
Appendix F - Composite Sample Plot Analytical Data: Provides tabular compilations of validated analytical results that provide a basis for the internal radiological dose estimates.

Appendix G -Sample Location Coordinates: Presents the northing and easting coordinates for each sample plot, the biased sample locations, and other points of interest.

Appendix H -Nevada Division of Environmental Protection (NDEP) Comments: Contains NDEP comments on the draft version of this document.

\subsubsection{Applicable Programmatic Plans and Documents}

All investigation activities were performed in accordance with the following documents:

- CAIP for CAU 371, Johnnie Boy Crater and Pin Stripe (NNSA/NSO, 2009)

- Industrial Sites Quality Assurance Project Plan (QAPP) (NNSA/NV, 2002a)

- FFACO (1996, as amended March 2010)

\subsubsection{Data Quality Assessment Summary}

The DQA is presented in Appendix B and includes an evaluation of the data quality indicators (DQIs) to determine the degree of acceptability and usability of the reported data in the decision-making process. The DQO process ensures that the right type, quality, and quantity of data will be available to support the resolution of those decisions with an appropriate level of confidence. Using both the DQO and DQA processes help to ensure that DQO decisions are sound and defensible.

The DQA process as presented in Appendix B is composed of the following steps:

- Step 1: Review DQOs and Sampling Design

- Step 2: Conduct a Preliminary Data Review

- Step 3: Select the Test

- Step 4: Verify the Assumptions

- Step 5: Draw Conclusions from the Data

Based on the results of the DQA presented in Appendix B, the nature and extent of COCs at CAU 371 have been adequately identified to implement corrective actions. The DQA also determined that information generated during the investigation support the CSM assumptions and the data collected met the DQOs and support their intended use in the decision-making process. 


\subsection{Corrective Action Investigation Summary}

The following sections summarize the investigation activities and investigation results, and justify why no further corrective action is required at CAU 371. Detailed investigation activities and results for individual CAU 371 CASs are presented in Appendix A of this document.

\section{$2.1 \quad$ Investigation Activities}

Corrective action investigation activities were performed as set forth in the CAU 371 CAIP (NNSA/NSO, 2009) from January 8, 2009, through February 16, 2010. The purpose of the CAU 371 CAI was to resolve the decision statements in the project-specific DQOs by:

- Determining whether COCs are present in the soils associated with CAU 371.

- Determining the extent of identified COCs.

- Ensuring adequate data have been collected to evaluate closure alternatives under the FFACO.

The scope of the CAI included the following activities:

- Performing visual surveys.

- Performing radiological surveys.

- Staging TLDs.

- Collecting environmental samples for laboratory analyses.

- Collecting QC samples for laboratory analyses.

To facilitate site investigation and the evaluation of DQO decisions for different conceptual site model (CSM) components, the releases at each CAS were classified into one of the following two categories:

- Primary releases are investigated via a combination of external dose assessment using TLDs and internal dose assessment through the collection and laboratory analysis of surface soil samples. For the purposes of this investigation, surface soils are defined as the top 5 centimeters (cm) of undisturbed soil. Sampling surface soils to a depth of $5 \mathrm{~cm}$ is appropriate for areas that have not been disturbed since the release because:

1. Numerous studies of soils contaminated by atmospheric deposition following nuclear testing at the NTS have shown that some 90 percent of the radioactivity in undisturbed soil is contained within the top $5 \mathrm{~cm}$ of soil (DRI, 1983 and 1985; Gilbert et al., 1977;

Tamura, 1977). 
2. The studies show that as radiological contaminants migrate downward in soils with water infiltration, the contaminant concentration profile exhibits a lognormal distribution with the maximum value remaining near the surface.

3. Sampling at a greater depth would collect non-contaminated soil along with the contaminated soil. This would serve to dilute the sample, reduce the analytical result (in units of picocuries per gram of sample), and lower the estimate of potential internal dose at the site.

- Other releases include any radionuclide contamination from test activities that is not limited to the surface $5 \mathrm{~cm}$ of soil. This includes radionuclide contaminants that were initially deposited onto the soil surface (as in the primary release category) but have subsequently been displaced through excavation or migration. This category also includes radionuclides that were deposited under mechanisms other than atmospheric deposition. This includes the injection of radionuclides into native material from the nuclear detonation (such as in the Johnnie Boy crater and in the fissure resulting from the Pin Stripe test), the deposition of ejecta piles around the Johnnie Boy crater, and any other chemical or radiological contamination discovered during the investigation through the identification of biasing factors that are not a part of a previously identified release. The depth of radiological contamination from other releases is dependent upon the nature of the release or subsequent movement through excavation or migration. Investigation of other releases was accomplished through measurements of soil radioactivity using a judgmental sampling scheme at depths dependent upon the nature of the release, or by conservative assumptions that radioactivity is present at depth based on process knowledge.

For the primary release at Pin Stripe, five sample plots (AA, AB, AC, AE, and AF) were established judgmentally based on the results of the gamma walkover surveys (GWSs) conducted at the site in order to demonstrate that COCs do not exist in surface soils. For other releases at Pin Stripe, a judgmental sample (Location A01, sample 371AX01) was collected from within the boundary of Plot AA at a depth of 25 to $30 \mathrm{~cm}$, at a location believed to coincide with a fissure that extends through the CAS. This biased sample was collected to verify the location of the fissure and determine whether contamination increases with depth within the fissure area. Sample locations are shown in Figure A.3-2.

For the primary release at Johnnie Boy, sample plots along each of three sampling vectors were established judgmentally based on the isopleths from the 1994 aerial survey (BN, 1999), with at least one plot located in each isopleth and, as possible, adjusted to coincide with sampling locations from Radionuclide Inventory and Distribution Program (RIDP) points (DRI, 1985; Gray et al., 2007). Four sample plots (BB, BC, BD, BP) were established along the north-oriented vector; four sample plots 
(BJ, BK, BL, BM) were established along the southwest-oriented vector; and five sample plots (BA, BE, BF, BG, BH) were established along the southeast-oriented vector. One additional sample plot $(\mathrm{BN})$ was established northeast of the crater within an area of elevated radiological readings. For other releases at Johnnie Boy, judgmental samples were collected from two areas of elevated radiological readings, adjacent to the northeast side of the crater, within the ejecta (Locations B03 and B04). Judgmental samples were also collected from two areas of sedimentation (Locations B01 and B02) within the major wash at Johnnie Boy, downgradient of the crater area. Sample locations are shown in Figure A.4-3.

Confidence in judgmental sampling scheme decisions was established qualitatively through validation of the CSM and verification that the selected plot locations meet the DQO criteria. Confidence in probabilistic sampling scheme decisions was established by validating the CSM, justifying that sampling locations are representative of the plot area, demonstrating that a sufficient number of samples were collected that acceptably characterize the plot, and demonstrating that contaminant distribution assumptions are valid and appropriate to the statistical test being performed.

The potential internal dose (determined from the laboratory analytical results of soil samples taken at each plot using the Residual Radioactive [RESRAD] computer code [Yu et al., 2001]) at each TLD location was conservatively assumed to be equal to the maximum internal dose calculated from any of the CAU 371 sampling plots. The potential external dose at each TLD location was determined from the results of a TLD placed at a height of 1 meter (m) above the soil surface. The net external dose (the gross TLD dose reading minus the background dose) was then divided by the number of hours the TLD was exposed to site contamination resulting in an hourly dose rate. That hourly dose rate was then multiplied by the number of hours per year $(\mathrm{hr} / \mathrm{yr})$ that a site worker would be present at the site (i.e., the annual exposure duration) to establish the maximum potential annual external dose a site worker could receive. The appropriate annual exposure duration in hours is based on the exposure scenario used (as defined in this section).

The calculated total effective dose (TED) (the sum of internal and external dose) for each sample plot is an estimation of the true radiological dose (true TED). The TED is defined in 10 Code of Federal Regulations (CFR) Part 835 (CFR, 2009) as the sum of the effective dose (for external exposures) and the committed effective dose (for internal exposures). 
Because a measured TED is an estimate of the true (unknown) TED, it is uncertain how well the calculated TED represents the true TED. If the measured TED were significantly different than the true TED, a decision based on the measured TED could result in a decision error. To reduce the probability of making a false negative decision error, a conservative estimate of the true TED is used to compare to the FAL instead of the measured TED. This conservative estimate (overestimation) of the true TED was calculated as the 95 percent upper confidence limit (UCL) of the average TED measurements. By definition, there will be a 95 percent probability that the true TED is less than the 95 percent UCL of the measured TED.

As described in Appendix C, the TED to a receptor from site contamination is a function of the time the receptor is present at the site and exposed to the radioactively contaminated soil. Therefore, TED is reported in this document based under the following three exposure scenarios:

- Industrial Area - Assumes continuous industrial use of a site. This scenario addresses exposure to industrial workers exposed daily to contaminants in soil during an average workday. This scenario assumes that this is the regular assigned work area for the worker who will be on the site for an entire career (225 days per year [day/yr], 10 hours per day [hr/day] for 25 years). The TED values calculated using this exposure scenario are the TED an industrial worker receives during 2,250 hours of annual exposure to site radioactivity and are expressed in terms of millirem per Industrial Area year (mrem/IA-yr).

- Remote Work Area - Assumes non-continuous work activities at a site. This scenario addresses exposure to industrial workers exposed to contaminants in soil during a portion of an average workday. This scenario assumes that this is an area where the worker regularly visits but is not an assigned work area where the worker spends an entire workday. A site worker under this scenario is assumed to be on the site for an equivalent of $336 \mathrm{hr} / \mathrm{yr}$ (or 42 day/yr) for an entire career (25 years). The TED values calculated using this exposure scenario are the TED a remote area worker receives during 336 hours of annual exposure to site radioactivity and are expressed in terms of millirem per Remote Work Area year (mrem/RW-yr).

- Occasional Use Area - Assumes occasional work activities at a site. This scenario addresses exposure to industrial workers who are not assigned to the area as a regular worksite but may occasionally use the site. This scenario assumes that this is an area where the worker does not regularly visit but may occasionally use for short-term activities. A site worker under this scenario is assumed to be on the site for an equivalent of 80 hours (or 10 days) per year, for 5 years. The TED values calculated using this exposure scenario are the TED an occasional use worker receives during 80 hours of annual exposure to site radioactivity and are expressed in terms of millirem per Occasional Use Area year (mrem/OU-yr). 
The following sections describe specific investigation activities conducted at each CAS. Additional information regarding the investigation is presented in Appendix A.

\subsubsection{Pin Stripe}

The following subsections summarize the investigation activities conducted at Pin Stripe.

\subsubsection{Description}

Investigation activities at Pin Stripe included performing visual inspections, conducting Global Positioning System (GPS)-assisted GWSs, staging TLDs, and collecting surface soil samples. During the visual inspections, no biasing factors were identified. The GWSs were conducted over the area surrounding the crater and the area north of the crater to identify locations of elevated radiological readings that would indicate the locations of the fissure and fallout plume. The results of the GWS showed that the highest gamma radiation readings corresponded to locations where the fissure was expected to be and confirmed that the fallout plume was positioned as expected. Three 100 -square-meter $\left(\mathrm{m}^{2}\right)$ sample plots were then established at the areas containing the highest anomalous readings as detected during the GWSs (see Figure A.3-1). A sample from the contaminated fissure media was collected from the location of the highest GWS values from a depth of 25 to $30 \mathrm{~cm}$.

Thermoluminescent dosimeters were installed at locations within Pin Stripe to measure external radiological doses. Sampling activities to determine internal dose at sample plots consisted of the collection of composite surface soil samples from five sample plots. Refer to Section A.3.1 for additional information on investigation activities at Pin Stripe. Results of the sampling effort are reported in Section 2.2.

\subsubsection{Conceptual Site Model Validation}

The CSM and associated discussion for this CAS are provided in the CAU 371 CAIP (NNSA/NSO, 2009). The contamination pattern of the radionuclides at Pin Stripe is consistent with the CSM in that the radiological contamination is greatest at the release point (fissure), generally decreases with distance from the release point, and is biased in the northerly (downwind) direction. 
Information gathered during the CAI supports and validates the CSM as presented in the CAU 371 CAIP (NNSA/NSO, 2009). No modification to the CSM was needed.

\subsubsection{Johnnie Boy}

The following subsections summarize the investigation activities conducted at Johnnie Boy.

\subsubsection{Description}

Investigation activities at Johnnie Boy included performing visual inspections, conducting GPS-assisted GWSs, staging TLDs, and collecting surface soil samples. During visual inspections, no biasing factors (aside from the ejecta and sedimentation sample locations) were identified. Radiological surveys (i.e., GWS and Bicron micro-REM Grid) were performed primarily around the crater and to the north to identify the spatial distribution of elevated radiological readings and verify the location of the fallout plume. A GWS was also conducted along the primary wash downgradient from the crater to investigate the potential for migration of radiological contamination. The TLDs were installed at selected locations within Johnnie Boy to measure external doses. Sampling activities to determine internal dose at sample plots included the collection of composite surface soil samples. Biased samples were also collected from two locations within the ejecta and two sedimentation areas within the primary wash at Johnnie Boy. Refer to Section A.4.1 for additional information on investigation activities conducted at Johnnie Boy. Results of the sampling effort are reported in Section 2.2.

\subsubsection{Conceptual Site Model Validation}

The CSM and associated discussion for this CAS are provided in the CAU 371 CAIP (NNSA/NSO, 2009). The contamination pattern of the radionuclides at Johnnie Boy is consistent with the CSM in that the radiological contamination generally decreases with distance from ground zero (GZ) and is biased in the northerly (downwind) direction. Information gathered during the CAI supports and validates the CSM as presented in the CAIP (NNSA/NSO, 2009). No modification to the CSM was needed. 


\subsection{Results}

Page 12 of 28

The data summary provided in Section 2.2.1 defines the COCs identified at CAU 371. Section 2.2.2 summarizes the assessment made in Appendix B, which demonstrates that the investigation results satisfy the DQO data requirements.

\subsubsection{Summary of Analytical Data}

Results for the both the primary releases and other releases are presented in Sections 2.2.1.1 and 2.2.1.2. The primary release results are reported as doses that are comparable to the dose-based FAL as established in Appendix C. For the other releases, the results are reported as individual radionuclide concentrations that are comparable to the individual radionuclide FALs as established in Appendix C.

The preliminary action levels (PALs) and FALs are based on an annual dose limit of 25 millirem per year (mrem/yr). This dose limit is specific to the annual dose a receptor could potentially receive from a CAU 371 release. As such, it is dependent upon the cumulative annual hours of exposure to site contamination. The PALs were established in the CAIP (NNSA/NSO, 2009) based on a dose limit of $25 \mathrm{mrem} / \mathrm{yr}$ over an annual exposure time of 2,250 hours (i.e., the Industrial Area exposure scenario that a site worker would be exposed to site contamination for 225 day/yr and $10 \mathrm{hr} /$ day). The FALs were established in Appendix $\mathrm{C}$ based on a dose limit of $25 \mathrm{mrem} / \mathrm{yr}$ over an annual exposure time of 336 hours (i.e., the Remote Work Area exposure scenario that a site worker would be exposed to site contamination for 42 day/yr and $8 \mathrm{hr} /$ day). To be comparable to these action levels, the CAU 371 investigation results are presented in terms of the dose a receptor would receive from site contamination under the Industrial Area (mrem/IA-yr), Remote Work Area (mrem/RW-yr), or Occasional Use Area (mrem/OU-yr) exposure scenarios.

\subsubsection{Pin Stripe}

Discussions of the results for samples collected at Pin Stripe are grouped by the nature of the release.

\section{Primary Release}

Measurements for the surface external dose that a receptor would receive at each sample plot under the three exposure scenarios (defined in Section 2.1) were derived from the net results of TLDs 
(total reading minus background value) for each TLD location. All TLD results presented or discussed in this document are net results. The TLD model used for this purpose was the Panasonic UD-814 TLD, which contains four individual elements. External dose at each TLD location is then determined using the readings from TLD elements 2,3 , and 4 (element 1 is designed to measure dose to the skin and is not relevant to the determination of the external dose for the purpose of this investigation). From these three independent measurements, the average TED and the 95 percent UCL of the average TED was calculated for each TLD location.

The internal dose estimates were calculated from laboratory analytical results of soil samples taken at each plot using the RESRAD computer code (Yu et al., 2001) (see Appendix C, Attachment C-1). The contribution of internal dose to the TED was not a significant portion of the TED (see Section A.3.2.3). Therefore, the maximum internal dose estimate from any sample plot was conservatively used for all TED calculations for each exposure scenario (the maximum internal value at this CAS was from plot AB; see Table A.3-4).

Calculation of the average TED for each sample was accomplished through summation of the external dose (i.e., TLD) measurement at each plot and the maximum internal dose estimate from plot AB. The average TED values for the plots at Pin Stripe are presented in Table 2-1.

Table 2-1

Pin Stripe TED at Sample Locations (mrem/yr)

\begin{tabular}{|c|c|c|c|c|c|c|}
\hline \multirow{2}{*}{$\begin{array}{l}\text { Plot or } \\
\text { Location }\end{array}$} & \multicolumn{2}{|c|}{ Industrial Area } & \multicolumn{2}{|c|}{ Remote Work Area } & \multicolumn{2}{|c|}{ Occasional Use Area } \\
\hline & $\begin{array}{c}\text { Average } \\
\text { TED }\end{array}$ & $\begin{array}{c}95 \% \text { UCL } \\
\text { of TED }\end{array}$ & $\begin{array}{c}\text { Average } \\
\text { TED }\end{array}$ & $\begin{array}{c}95 \% \text { UCL } \\
\text { of TED }\end{array}$ & $\begin{array}{c}\text { Average } \\
\text { TED }\end{array}$ & $\begin{array}{c}95 \% \text { UCL } \\
\text { of TED }\end{array}$ \\
\hline AA & 60.9 & 71.6 & 9.1 & 10.7 & 2.2 & 2.5 \\
\hline$A B$ & 35.9 & 45.8 & 5.4 & 6.8 & 1.3 & 1.6 \\
\hline$A C$ & 23.0 & 30.6 & 3.4 & 4.6 & 0.8 & 1.1 \\
\hline$A D$ & 4.6 & 11.2 & 0.7 & 1.7 & 0.2 & 0.4 \\
\hline $\mathrm{AE}$ & 5.3 & 12.9 & 0.8 & 1.9 & 0.2 & 0.5 \\
\hline $\mathrm{AF}$ & 8.7 & 16.5 & 1.3 & 2.5 & 0.3 & 0.6 \\
\hline
\end{tabular}

Bold indicates the values exceeding $25 \mathrm{mrem} / \mathrm{yr}$. 
Values for the 95 percent UCL of the TED for the Industrial Area, Remote Work Area, and Occasional Use Area exposure scenarios were calculated by adding the 95 percent UCL of the mean TLD values and the 95 percent UCL value of the maximum internal dose estimate from plot AB. These values are presented in Table 2-1.

The FALs were established in Appendix C based on the annual exposure duration of the Remote Work Area scenario (336 hr/yr). Under this exposure scenario, the TEDs for surface soils did not exceed the FAL of 25 mrem/RW-yr at any Pin Stripe location. However, it is assumed that subsurface contamination is present in the fissure that exceeds the FAL (see Section D.1.1).

\section{Other Release}

One sample (371AX01) was collected from contaminated fissure material at Pin Stripe based on the highest GWS values. This sample was collected at the depth of 25 to $30 \mathrm{~cm}$ below ground surface (bgs) near the TLD location within Plot AA for the purpose of sampling fissure media. The analytical result of 425 picocuries per gram (pCi/g) exceeded the PAL of $12.7 \mathrm{pCi} / \mathrm{g}$ for Cs-137 (based on the Industrial Area exposure scenario). However, it did not exceed the FAL (based on the Remote Work Area exposure scenario [see Table A.3-10]) of 487.4 pCi/g as established in Appendix C.

\section{Summary of Investigation Results at Pin Stripe}

Based on the analytical results for surface soil samples collected within Pin Stripe, no surface soil COCs were identified at this CAS. However, it is assumed that COCs are present in the contaminated fissure (see Section D.1.1). Therefore, COCs are assumed to be present in subsurface soils at this CAS, and a corrective action is required. The selected corrective action (based on the corrective action evaluation presented in Appendix E) for the subsurface contamination is closure in place with a UR. A UR was established that encompasses the area of the Pin Stripe crater as well as the identified surface expression of the fissure that extends beyond the crater, as shown in Figure 2-1.

\subsubsection{Johnnie Boy}

Discussions of the results for samples collected at Johnnie Boy are grouped by the nature of the release. 


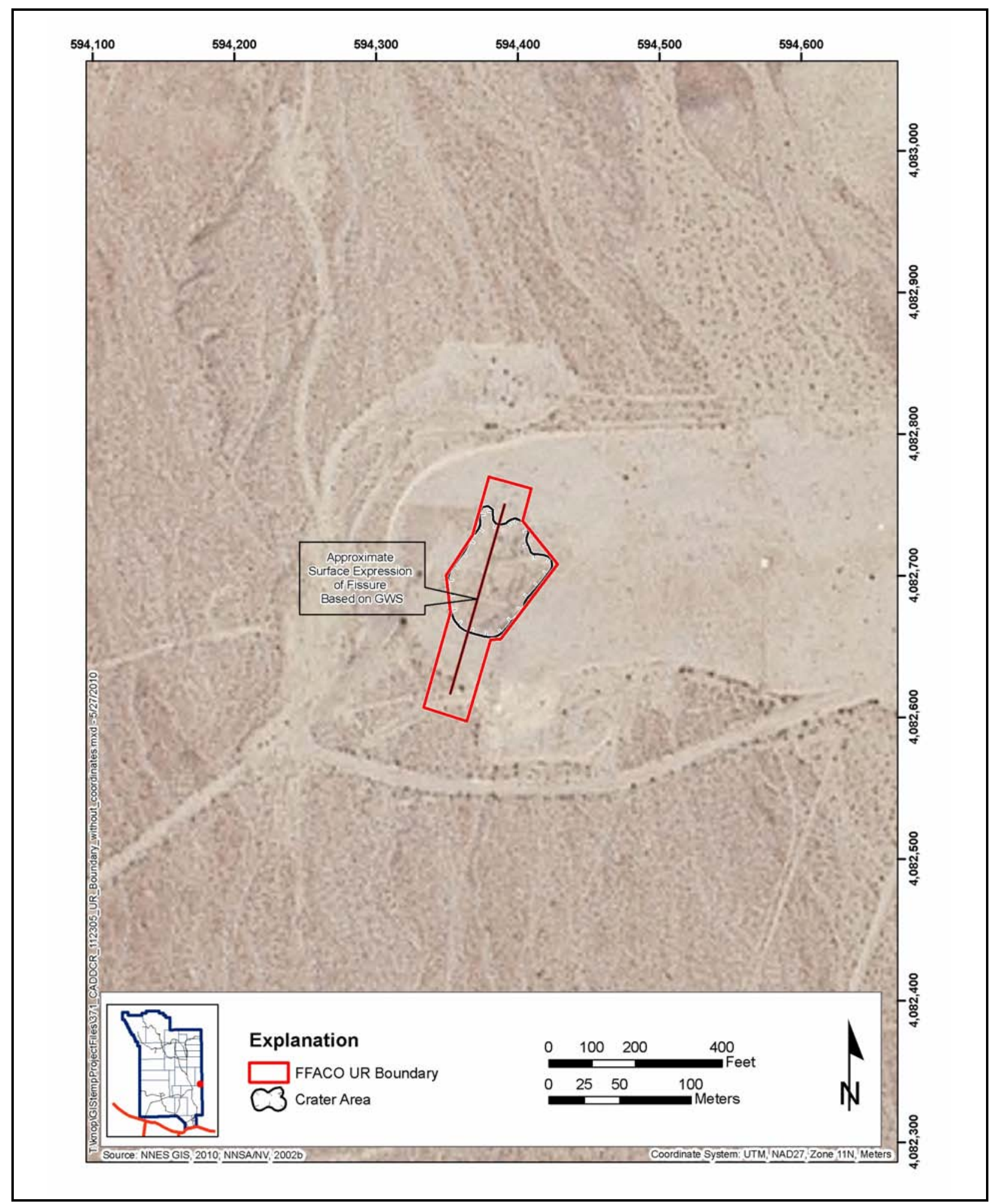

Figure 2-1

FFACO UR Boundary for Pin Stripe 


\section{Primary Release}

Measurements for the surface external dose that a receptor would receive at each sample plot under the three exposure scenarios (defined in Section 2.1) were derived from the net results of TLDs (total reading minus background value) for each TLD location using the readings from each of three TLD elements. From these three independent measurements, the average TED and the 95 percent UCL of the average TED was calculated for each TLD.

The internal dose estimates were calculated by evaluating the laboratory analytical results of soil samples taken at each plot using the RESRAD computer code (Yu et al., 2001) (see Appendix C, Attachment C-1). The contribution of internal dose to the TED was not a significant portion of the TED (see Section A.3.2.3). Therefore, the maximum internal dose estimate from any sample plot was conservatively used for all TED calculations for each exposure scenario (the maximum internal value at this CAS was from plot BC; see Table A.4-5).

Calculation of the average TED for each sample was accomplished through summation of the external dose (TLD) measurement at each location and the highest internal dose estimate from plot BC. The average TED values for each exposure scenario for the plots at Johnnie Boy are presented in Table 2-2.

Table 2-2

Johnnie Boy TED at Sample Locations (mrem/yr) (Page 1 of 2)

\begin{tabular}{||c||c|c||c|c||c|c||}
\hline \multirow{2}{*}{$\begin{array}{c}\text { Plot or } \\
\text { Location }\end{array}$} & \multicolumn{2}{c||}{ Industrial Area } & \multicolumn{2}{c||}{ Remote Work Area } & \multicolumn{2}{c||}{ Occasional Use Area } \\
\cline { 2 - 7 } & $\begin{array}{c}\text { Average } \\
\text { TED }\end{array}$ & $\begin{array}{c}\mathbf{9 5 \%} \text { UCL } \\
\text { of TED }\end{array}$ & $\begin{array}{c}\text { Average } \\
\text { TED }\end{array}$ & $\begin{array}{c}\mathbf{9 5 \%} \text { UCL } \\
\text { of TED }\end{array}$ & $\begin{array}{c}\text { Average } \\
\text { TED }\end{array}$ & $\begin{array}{c}\text { 95\% UCL } \\
\text { of TED }\end{array}$ \\
\hline \hline BA & $\mathbf{4 4 . 4}$ & $\mathbf{4 9 . 9}$ & 6.6 & 7.4 & 1.6 & 1.8 \\
\hline BB & $\mathbf{3 0 . 6}$ & $\mathbf{3 8 . 0}$ & 4.6 & 5.7 & 1.1 & 1.4 \\
\hline BC & $\mathbf{3 3 . 2}$ & $\mathbf{3 7 . 8}$ & 5.0 & 5.6 & 1.2 & 1.3 \\
\hline BD & 23.1 & $\mathbf{2 9 . 0}$ & 3.5 & 4.3 & 0.8 & 1.0 \\
\hline BE & $\mathbf{5 0 . 8}$ & $\mathbf{6 2 . 9}$ & 7.6 & 9.4 & 1.8 & 2.2 \\
\hline BF & 18.0 & 23.3 & 2.7 & 3.5 & 0.6 & 0.8 \\
\hline BG & 10.1 & 15.7 & 1.5 & 2.3 & 0.4 & 0.6 \\
\hline BH & 1.3 & 3.3 & 0.2 & 0.5 & 0.05 & 0.1 \\
\hline BJ & $\mathbf{5 6 . 8}$ & $\mathbf{6 3 . 1}$ & 8.5 & 9.4 & 2.0 & 2.2 \\
\hline
\end{tabular}


Table 2-2

Johnnie Boy TED at Sample Locations (mrem/yr) (Page 2 of 2)

\begin{tabular}{|c|c|c|c|c|c|c|}
\hline \multirow{2}{*}{$\begin{array}{l}\text { Plot or } \\
\text { Location }\end{array}$} & \multicolumn{2}{|c|}{ Industrial Area } & \multicolumn{2}{|c|}{ Remote Work Area } & \multicolumn{2}{|c|}{ Occasional Use Area } \\
\hline & $\begin{array}{c}\text { Average } \\
\text { TED }\end{array}$ & $\begin{array}{c}95 \% \text { UCL } \\
\text { of TED }\end{array}$ & $\begin{array}{c}\text { Average } \\
\text { TED }\end{array}$ & $\begin{array}{c}\text { 95\% UCL } \\
\text { of TED }\end{array}$ & $\begin{array}{c}\text { Average } \\
\text { TED }\end{array}$ & $\begin{array}{c}\text { 95\% UCL } \\
\text { of TED }\end{array}$ \\
\hline BK & 35.8 & 45.1 & 5.3 & 6.7 & 1.3 & 1.6 \\
\hline $\mathrm{BL}$ & 12.3 & 15.0 & 1.8 & 2.2 & 0.4 & 0.5 \\
\hline BM & 2.1 & 5.5 & 0.3 & 0.8 & 0.1 & 0.2 \\
\hline $\mathrm{BN}$ & 55.4 & 66.8 & 8.3 & 10.0 & 2.0 & 2.4 \\
\hline BP & 14.3 & 18.7 & 2.1 & 2.8 & 0.5 & 0.7 \\
\hline BQ & 15.2 & 20.8 & 2.3 & 3.1 & 0.5 & 0.7 \\
\hline BR & 14.4 & 19.1 & 2.2 & 2.9 & 0.5 & 0.7 \\
\hline BS & 14.5 & 18.4 & 2.2 & 2.7 & 0.5 & 0.7 \\
\hline BT & 4.0 & 7.1 & 0.6 & 1.1 & 0.1 & 0.3 \\
\hline BU & 4.3 & 9.3 & 0.6 & 1.4 & 0.2 & 0.3 \\
\hline BV & 0.04 & 5.4 & 0.006 & 0.8 & 0.002 & 0.2 \\
\hline$B Z$ & 13.7 & 18.6 & 2.1 & 2.8 & 0.5 & 0.7 \\
\hline
\end{tabular}

Bold indicates the values exceeding $25 \mathrm{mrem} / \mathrm{yr}$.

Values for the 95 percent UCL of the TED for the Industrial Area, Remote Work Area, and Occasional Use Area exposure scenarios were calculated by adding the 95 percent UCL of the mean TLD values and the 95 percent UCL values of the maximum internal dose estimate from plot BC. These values are presented in Table 2-2.

The FAL established for Johnnie Boy was 25 mrem/RW-yr based on the annual exposure duration of the Remote Work Area exposure scenario (336 hr/yr) as established in Appendix C. Under this exposure scenario, the TEDs from surface soil did not exceed the FAL of 25 mrem/RW-yr at any Johnnie Boy plots. However, it is assumed that subsurface contamination is present in the crater that exceeds the FAL (see Section D.1.1).

\section{Other Release}

Samples were collected at Johnnie Boy from two sedimentation areas within the major wash and two areas of elevated radiological readings in the ejecta. Samples from each sedimentation area were 
collected at the surface ( 0 to $5 \mathrm{~cm}$ bgs) and at the shallow subsurface (5 to $10 \mathrm{~cm}$ bgs). Samples from each of two areas of elevated radiological readings in the ejecta were collected at the surface (0 to $5 \mathrm{~cm}$ bgs) and at two depths (5 to 10 and 25 to $30 \mathrm{~cm}$ bgs). The analytical results from these samples exceeded PALs based on the Industrial Area exposure scenario. However, they did not exceed the FALs based on the Remote Work Area exposure scenario as established in Appendix C (Table 2-3).

Table 2-3

Maximum Detected Sample Results for Other Releases at Johnnie Boy

\begin{tabular}{|c|c|c|c|c|c|c|}
\hline Contaminant & $\begin{array}{c}\text { Maximum } \\
\text { Result }\end{array}$ & $\begin{array}{c}\text { Sample } \\
\text { Number }\end{array}$ & $\begin{array}{c}\text { Depth } \\
\text { (cm bgs) }\end{array}$ & Location & FAL & Units \\
\hline \hline Th-232 & 2.73 & $371 \mathrm{BX04}$ & $5.0-10.0$ & $\mathrm{~B} 02$ & 3,292 & $\mathrm{pCi} / \mathrm{g}$ \\
\hline $\mathrm{Am}-241$ & 0.122 & $371 \mathrm{BX04}$ & $5.0-10.0$ & $\mathrm{~B} 02$ & 9,239 & $\mathrm{pCi} / \mathrm{g}$ \\
\hline $\mathrm{Cs}-137$ & 134 & $371 \mathrm{~B} \times 13$ & $25.0-30.0$ & $\mathrm{~B} 04$ & 487.4 & $\mathrm{pCi} / \mathrm{g}$ \\
\hline $\mathrm{Co}-60$ & 2.18 & $371 \mathrm{BX} 11$ & $0.0-5.0$ & $\mathrm{~B} 04$ & 122.5 & $\mathrm{pCi} / \mathrm{g}$ \\
\hline $\mathrm{Eu}-152$ & $28.7(\mathrm{~J})$ & $371 \mathrm{BX} 11$ & $0.0-5.0$ & $\mathrm{~B} 04$ & 255.7 & $\mathrm{pCi} / \mathrm{g}$ \\
\hline $\mathrm{Eu}-154$ & $5.5(\mathrm{~J})$ & $371 \mathrm{BX05}$ & $0.0-5.0$ & $\mathrm{~B} 03$ & 238.7 & $\mathrm{pCi} / \mathrm{g}$ \\
\hline $\mathrm{Pu}-238$ & 0.131 & $371 \mathrm{BX04}$ & $5.0-10.0$ & $\mathrm{~B} 02$ & 13,900 & $\mathrm{pCi} / \mathrm{g}$ \\
\hline $\mathrm{Pu}-239 / 240$ & 1.2 & $371 \mathrm{BX} 11$ & $0.0-5.0$ & $\mathrm{~B} 04$ & 12,690 & $\mathrm{pCi} / \mathrm{g}$ \\
\hline $\mathrm{Sr}-90$ & 15.8 & $371 \mathrm{BX} 12$ & $5.0-10.0$ & $\mathrm{~B} 04$ & 55,220 & $\mathrm{pCi} / \mathrm{g}$ \\
\hline $\mathrm{U}-234$ & 30.1 & $371 \mathrm{BX} 11$ & $0.0-5.0$ & $\mathrm{~B} 04$ & 131,400 & $\mathrm{pCi} / \mathrm{g}$ \\
\hline $\mathrm{U}-235$ & 1.01 & $371 \mathrm{BX} 11$ & $0.0-5.0$ & $\mathrm{~B} 04$ & 1,709 & $\mathrm{pCi} / \mathrm{g}$ \\
\hline $\mathrm{U}-238$ & 1.23 & $371 \mathrm{BX01}$ & $0.0-5.0$ & $\mathrm{~B} 01$ & 9,572 & $\mathrm{pCi} / \mathrm{g}$ \\
\hline
\end{tabular}

$\begin{array}{ll}\text { Am }=\text { Americium } & \mathrm{Pu}=\text { Plutonium } \\ \mathrm{Cs}=\text { Cesium } & \mathrm{Sr}=\text { Strontium } \\ \mathrm{Co}=\text { Cobalt } & \mathrm{Th}=\text { Thorium } \\ \mathrm{Eu}=\text { Europium } & \mathrm{U}=\text { Uranium } \\ \mathrm{J}=\text { Estimated value } & \end{array}$

\section{Summary of Releases at Johnnie Boy}

Based on the analytical results for surface soil samples collected within Johnnie Boy, no COCs were identified in surface soils at this CAS. However, it is assumed that COCs are present in the crater that exceed the FAL due to direct injection of radionuclides into the subsurface soil from the nuclear test. Therefore, COCs are assumed to be present in subsurface soils at this CAS and a corrective action is 
required. The selected corrective action (based on the corrective action evaluation presented in Appendix E) for the subsurface contamination is closure in place with a UR. A UR was established that encompasses the area of the Johnnie Boy crater as well as the crater lip surrounding the crater as shown in Figure 2-2.

\subsubsection{Data Assessment Summary}

The DQA is presented in Appendix B and includes an evaluation of the DQIs to determine the degree of acceptability and usability of the reported data in the decision-making process. The DQO process ensures that the right type, quality, and quantity of data are available to support the resolution of those decisions at an appropriate level of confidence. Using both the DQO and DQA processes help to ensure that DQO decisions are sound and defensible.

The DQA process as presented in Appendix B is composed of the following steps:

- Step 1: Review DQOs and Sampling Design.

- Step 2: Conduct a Preliminary Data Review.

- Step 3: Select the Test.

- Step 4: Verify the Assumptions.

- Step 5: Draw Conclusions from the Data.

The DQA results support DQO decisions on the presence and/or extent of contamination at each CAS. Based on the results of the DQA presented in Appendix B, the DQO requirements have been met. The DQA also determined that information generated during the investigation support the CSM assumptions and the data collected support their intended use in the decision-making process.

\subsection{Justification for No Further Action}

No further corrective action is needed for the two CASs within CAU 371 based on implementation of the corrective action of closure in place with a UR. This corrective action was selected to ensure protection of the public and the environment in accordance with Nevada Administrative Code (NAC) 445A (NAC, 2008) based on an evaluation of risk, feasibility, and cost effectiveness (the evaluation of CAAs is presented in Appendix E). 


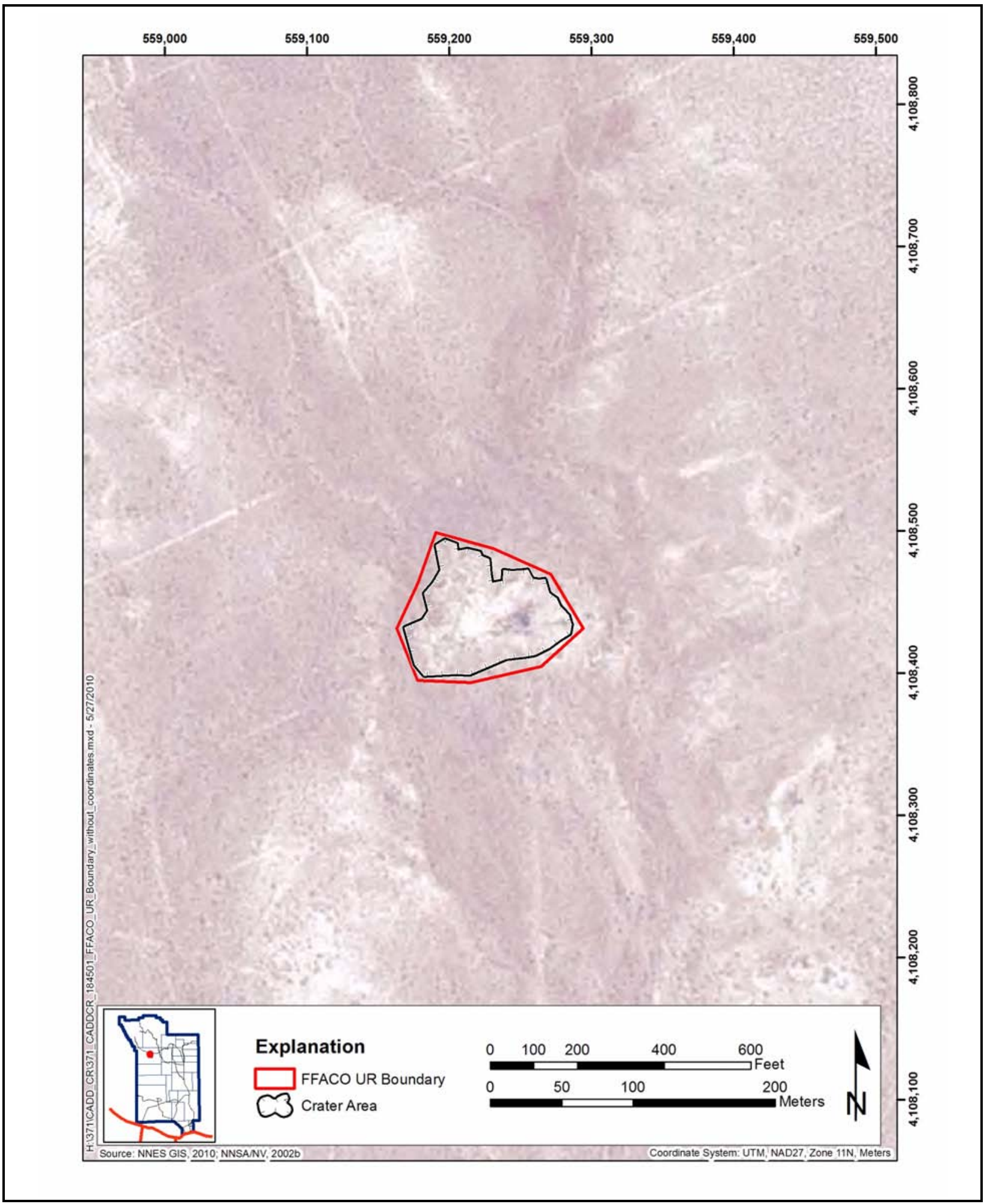

Figure 2-2

FFACO UR Boundary for Johnnie Boy 


\subsubsection{Final Action Levels}

The establishment of the FALs (presented in Appendix C) was based on risk to receptors. The risk to receptors from contaminants at CAU 371 is due to chronic exposure to radionuclides (i.e., receiving a dose over time). Therefore, the risk to a receptor is directly related to the amount of time a receptor is exposed to the contaminants. A review of the current and projected use of both sites determined that workers may only be present at these sites for a few hours per year, and it is not reasonable to assume that any worker would be present at this site on a full-time basis (DOE/NV, 1996). In the CAU 371 DQOs, it was conservatively determined that the Occasional Use Area exposure scenario (as listed in Section 3.1.1 of the CAU 371 CAIP [NNSA/NSO, 2009]) would be used in calculating receptor exposure time. This exposure scenario assumes workers may use the site occasionally for intermittent or short-term activities and be exposed to site contaminants for $80 \mathrm{hr} / \mathrm{yr}$ (i.e., equivalent to $8 \mathrm{hr} /$ day, 10 day/yr, for 5 years).

Using the maximum dose measured at any Pin Stripe surface location, a receptor would have to be exposed to the location of maximum dose for 922 hours to receive a dose of 25 millirem (mrem). Similarly, based on the maximum dose measured at any Johnnie Boy surface location, a receptor would have to be exposed to the location of maximum dose for 990 hours to receive a dose of 25 mrem. Based on the required exposure times to potentially receive a 25-mrem/yr dose, a receptor under the more conservative exposure scenario of Remote Work Area (336 hr/yr) could not exceed the 25-mrem/yr dose limit at either CAS. Therefore, it was decided to base the FALs on the Remote Work Area exposure scenario.

Using this FAL, corrective actions would not be required as long as receptors are not exposed to site radioactivity for more than $336 \mathrm{hr} / \mathrm{yr}$. Any site activity that would not require a receptor to be exposed to contaminants outside the corrective action boundary for more than $336 \mathrm{hr} / \mathrm{yr}$ could not result in a dose above 25 mrem and would not need to be restricted. This would include activities such as road maintenance, military exercises, maintenance of postings, etc. 


\subsection{Recommendation}

Corrective action decisions for both CASs were based on the risk assessment presented in Appendix C. This assessment determined to use the Remote Work Area exposure scenario (with an exposure duration of $336 \mathrm{hr} / \mathrm{yr}$ of site worker exposure) as the FAL for DQO decisions.

Based on the FAL of 25 mrem/RW-yr, no COCs were identified from sample plot surface results at Pin Stripe; however, it is assumed that subsurface contamination is present in the fissure that exceeds the FAL. Thus corrective action is required. At Pin Stripe, a corrective action of closure in place with a UR was implemented for the subsurface radioactive contamination within the fissure. The UR includes the crater and the area where the surface expression of the fissure extends beyond the crater.

Based on the FAL of 25 mrem/RW-yr, no COCs were identified from sample plot surface results at Johnnie Boy; however, it is assumed that subsurface contamination is present in the crater that exceeds the FAL due to direct injection of radionuclides into the subsurface soil from the nuclear test. Thus corrective action is required. At Johnnie Boy, a corrective action of closure in place with a UR was implemented for the subsurface radioactive contamination within the area of the crater and crater lip.

As a BMP, it was determined to identify and administratively use restrict (administrative UR) any area at either CAS where an industrial land use of the area could cause a future full-time industrial site worker to receive a dose exceeding $25 \mathrm{mrem} / \mathrm{yr}$. This would prevent any future activities that would require a worker to be exposed to site contamination (i.e., potential to be exposed to site contamination for $10 \mathrm{hr} /$ day for $225 \mathrm{day} / \mathrm{yr}$ or 2,250 hr/yr).

At Pin Stripe, the TED calculated using an exposure duration of 2,250 hr/yr (Industrial Area scenario) exceeded a dose of 25 mrem at plots AA, AB, and AC (located within the FFACO UR). This assessment determined that there are no locations outside the UR boundary at Pin Stripe that would provide sufficient dose to potentially cause a full-time industrial worker to receive an annual dose exceeding 25 mrem. Therefore, an additional administrative UR for this CAS was not necessary.

At Johnnie Boy, the TED from surface soils exceeded a dose of 25 mrem under the Industrial Area scenario exposure time at plots BA, BB, BC, BD, BE, BJ, BK, and BN (see Table A.4-8). The area of 
the administrative UR that encompasses these plots was established as the radiation survey isopleth estimated to correspond with a TED of 25 mrem/IA-yr (see Section A.4.3).

The UR areas are depicted in Figures 3-1, 3-2, and 3-3. The URs are recorded in the FFACO database; the DOE, National Nuclear Security Administration Nevada Site Office (NNSA/NSO) Facility Information Management System; and the NNSA/NSO CAU/CAS files.

No further corrective action is required at CAU 371 based upon implementation of corrective actions at both CAU 371 CASs. These corrective actions are evaluated in Appendix E based on technical merits focusing on performance, reliability, feasibility, and safety. The FFACO URs implemented at each CAS will protect site workers from inadvertent exposure. These FFACO URs require annual inspections to certify that postings are in place, intact, and readable. Maintenance or replacement of postings can be conducted without prior approval from NDEP. The corrective actions for CAU 371 are based on the assumption that activities on the NTS will be limited to those that are industrial in nature and that the NTS will maintain controlled access (i.e., restrict public access and residential use). Should the future land use of the NTS change such that these assumptions no longer are valid, additional evaluation may be necessary.

The administrative UR at Johnnie Boy is not part of the corrective action but was implemented as a BMP. The administrative UR will be recorded and controlled in the same manner as the FFACO URs but will not require postings or inspections. The URs are included in Appendix D.

The NNSA/NSO requests that NDEP issue a Notice of Completion for this CAU and approve moving the CAU from Appendix III to Appendix IV of the FFACO. 


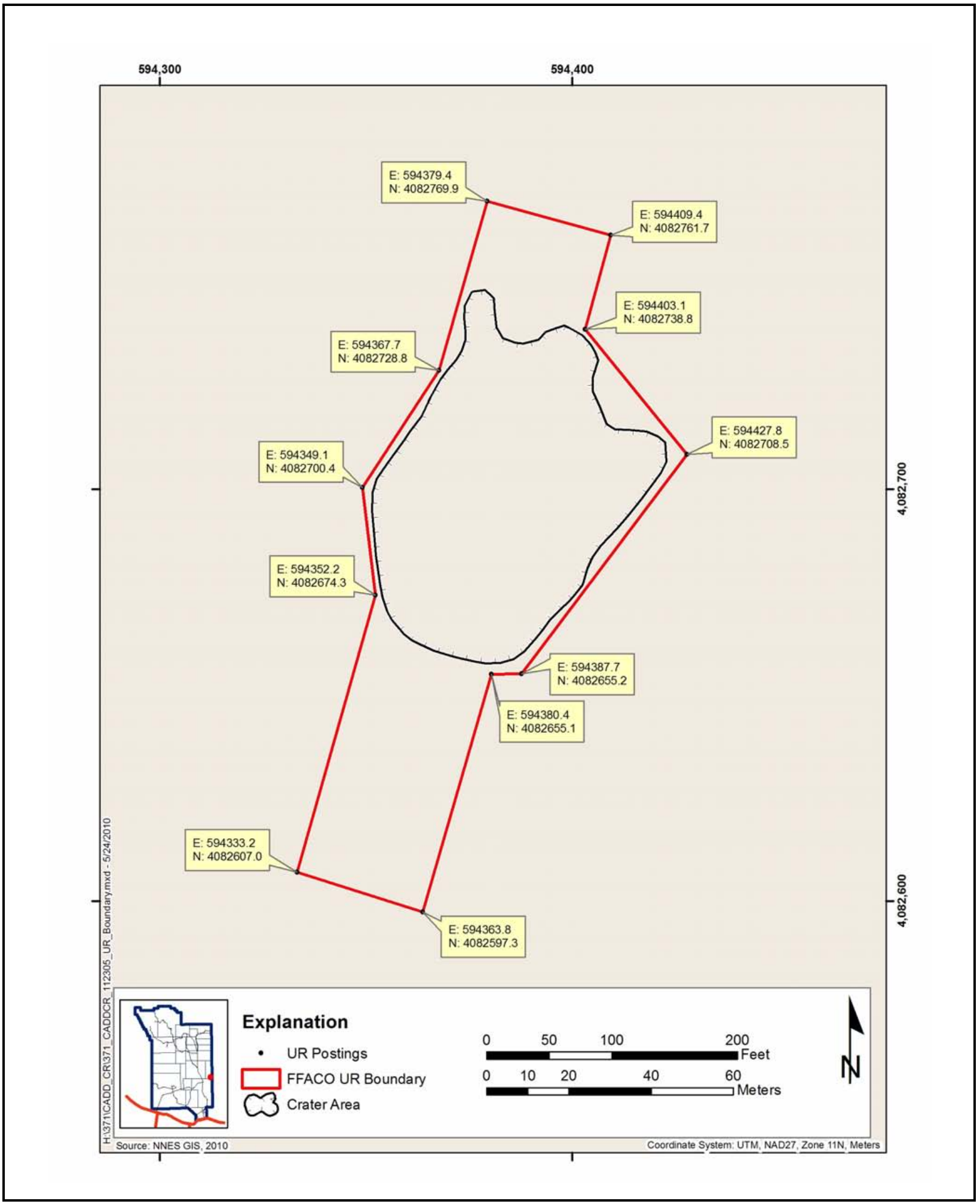

Figure 3-1

Pin Stripe UR Boundary 


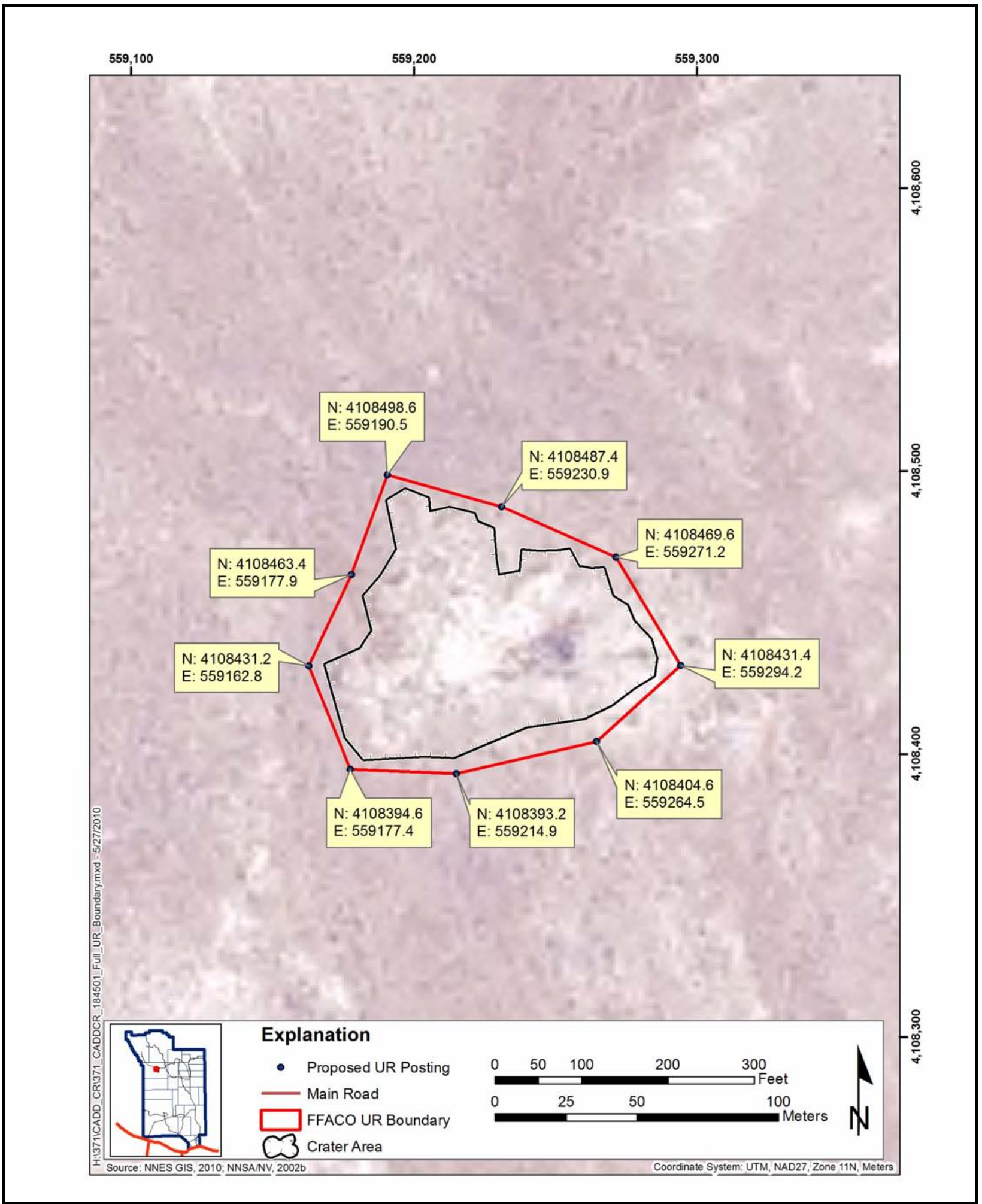

Figure 3-2

Johnnie Boy UR Boundary 


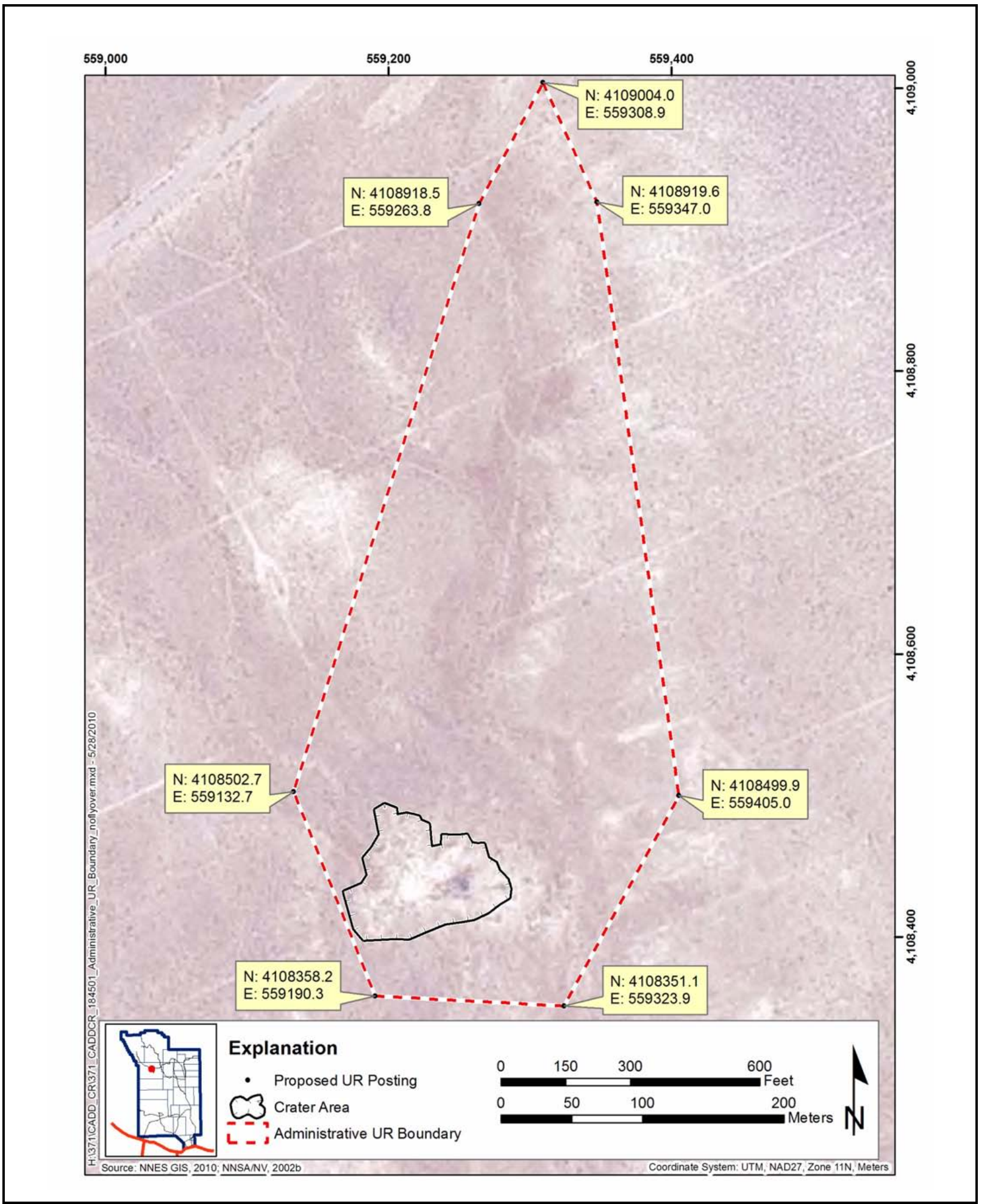

Figure 3-3

Johnnie Boy Administrative UR Boundary 


\subsection{References}

BN, see Bechtel Nevada.

Bechtel Nevada. 1999. An Aerial Radiological Survey of the Nevada Test Site, DOE/NV/11718--324. Prepared for the U.S. Department of Energy, Nevada Operations Office. Las Vegas, NV: Remote Sensing Laboratory.

CFR, see Code of Federal Regulations.

Code of Federal Regulations. 2009. Title 10 CFR Part 835, “Occupational Radiation Protection.” Washington, DC: U.S. Government Printing Office.

DOE/NV, see U.S. Department of Energy, Nevada Operations Office.

DRI, see Desert Research Institute.

Desert Research Institute. 1983. Radionuclide Inventory and Distribution Program: The Galileo Area, DOE/NV/10162-14. Prepared by R.D. McArthur and J.F. Kordas. Las Vegas, NV.

Desert Research Institute. 1985. Nevada Test Site Radionuclide Inventory and Distribution Program: Report \#2, Areas 2 and 4, DOE/NV/10162-20. Prepared by R.D. McArthur and J.F. Kordas. Las Vegas, NV.

FFACO, see Federal Facility Agreement and Consent Order.

Federal Facility Agreement and Consent Order. 1996 (as amended March 2010). Agreed to by the State of Nevada; U.S. Department of Energy, Environmental Management; U.S. Department of Defense; and U.S. Department of Energy, Legacy Management.

Gilbert, R.O., E.H. Essington, D.N. Brady, P.G. Doctor, and L.L Eberhardt. 1977. "Statistical Activities during 1976 and the Design and Initial Analysis of Nuclear Site Studies." In Transuranics in Desert Ecosystems, NVO-181. pp. 331-366. November. Las Vegas, NV: U.S. Department of Energy, Nevada Operations Office.

Gray, K.J., D.S. Shafer, K. Self, C. Martin, and R. McArthur. 2007. Radionuclide Inventory and Distribution Program (RIDP) Database, Rev. 2. April. Las Vegas, NV.

NAC, see Nevada Administrative Code.

NNES GIS, see Navarro Nevada Environmental Services Geographic Information Systems. 
NNSA/NSO, see U.S. Department of Energy, National Nuclear Security Administration Nevada Site Office.

NNSA/NV, see U.S. Department of Energy, National Nuclear Security Administration Nevada Operations Office.

Nevada Administrative Code. 2008. NAC 445A, "Water Controls.” Carson City, NV. As accessed at http://www.leg.state.nv.us/nac on 15 January 2010.

Navarro Nevada Environmental Services Geographic Information Systems. 2008. ESRI ArcGIS Software.

Tamura, T. 1977. "Plutonium Distribution in a Desert Pavement-Desert Mound Soil System in Area 11.” In Environmental Plutonium on the Nevada Test Site and Environs, NVO-171. June. Las Vegas, NV: Energy Research and Development Administration.

U.S. Department of Energy, National Nuclear Security Administration Nevada Operations Office. 2002a. Industrial Sites Quality Assurance Project Plan, Nevada Test Site, Nevada, Rev. 3, DOE/NV--372. Las Vegas, NV.

U.S. Department of Energy, National Nuclear Security Administration Nevada Operations Office. 2002b. Nevada Test Site Orthophoto Site Atlas, DOE/NV/11718--604. Prepared by Bechtel Nevada. Las Vegas, NV.

U.S. Department of Energy, National Nuclear Security Administration Nevada Site Office. 2009. Corrective Action Investigation Plan for Corrective Action Unit 371: Johnnie Boy Crater and Pin Stripe, Nevada Test Site, Nevada, Rev. 0, DOE/NV--1310. Las Vegas, NV.

U.S. Department of Energy, Nevada Operations Office. 1996. Final Environmental Impact Statement for the Nevada Test Site and Off-Site Locations in the State of Nevada, DOE/EIS-0243. Las Vegas, NV.

Yu, C., A.J. Zielen, J.J. Cheng, D.J. LePoire, E. Gnanapragasam, S. Kamboj, J. Arnish, A. Wallo III, W.A. Williams, and H. Peterson. 2001. User's Manual for RESRAD Version 6, ANL/EAD-4. Argonne, IL: Argonne National Laboratory, Environmental Assessment Division. (Version 6.4 released in December 2007.) 


\section{Appendix A}

\section{Corrective Action Investigation Results}




\section{A.1.0 Introduction}

This appendix presents the CAI activities and analytical results for CAU 371. Corrective Action Unit 371 consists of two CASs located in Areas 11 and 18 of the NTS (Figure A.1-1):

- 11-23-05, Pin Stripe Contamination Area

- $\quad$ 18-45-01, U-18j-2 Crater (Johnnie Boy)

Corrective Action Site 11-23-05 (referred to as Pin Stripe in this document) is located in Area 11 of the NTS north of the Area 5 Radioactive Waste Management Site (RWMS). Pin Stripe consists of a release of surface and near-surface radioactive contamination as a result of the venting of radiological material from a fissure formed during the Pin Stripe (U11b) weapons-effects test.

Corrective Action Site 18-45-01 (referred to as Johnnie Boy in this document) is located in Area 18 of the NTS, approximately 500 m south of the 18-03 Road. Johnnie Boy consists of the deposition of radioactive contamination as a result of the Johnnie Boy (U-18j-2) weapons-effects test.

Additional information regarding the history of each site, planning, and the scope of the investigation is presented in the CAU 371 CAIP (NNSA/NSO, 2009b).

\section{A.1.1 Project Objectives}

The primary objective of the investigation was to provide sufficient information to evaluate appropriate CAAs for each CAS in CAU 371. This objective was achieved by identifying the nature and extent of COCs, and the evaluation and selection of an acceptable CAA.

The selection of soil characterization sample locations was based on site conditions and the strategy developed during the DQO process as presented in the CAU 371 CAIP (NNSA/NSO, 2009b). The sampling strategy for both CASs in CAU 371 involved the judgmental selection of sample plot locations and the probabilistic selection of composite sample (aliquot) locations within each plot. Sample plot locations were chosen based upon the results of GWSs conducted at each site, historical investigations (1994 aerial radiological survey [BN, 1999] and RIDP data [DRI, 1985; Gray et al., 2007]), and site conditions. At each sample plot, the internal dose to a receptor was estimated based on analytical results from the composite soil samples, and the external dose to a 


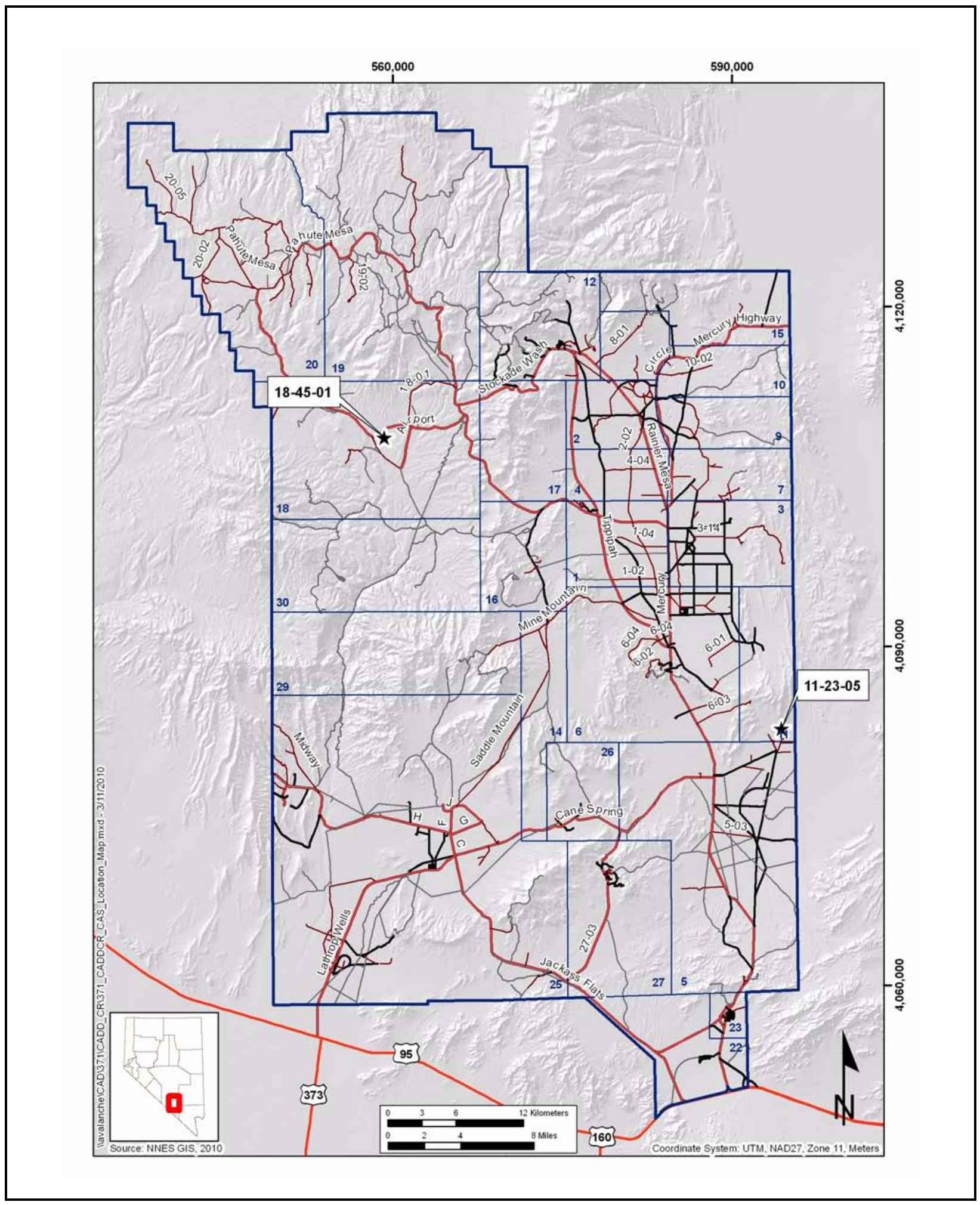

Figure A.1-1

CAU 371, CAS Location Map 
receptor was determined from TLDs staged at each plot. Additional judgmental samples were collected at each CAS in order to determine whether migration has occurred or to evaluate subsurface contamination.

\section{A.1.2 Contents}

This appendix describes the investigation and presents the results. The contents of this appendix are as follows:

- Section A.1.0 describes the investigation background, objectives, and contents.

- Section A.2.0 provides an investigation overview.

- Sections A.3.0 and A.4.0 provide CAS-specific information regarding the field activities, sampling methods, and laboratory analytical results from investigation sampling.

- Section A.5.0 summarizes waste management activities.

- Section A.6.0 discusses the QA and QC processes followed and the results of QA/QC activities.

- Section A.7.0 provides a summary of the investigation results.

- Section A.8.0 lists the cited references.

The complete field documentation and laboratory data—including field activity daily logs, sample collection logs (SCLs), analysis request/chain-of-custody forms, soil sample descriptions, laboratory certificates of analyses, and analytical results - are retained in project files as hard copy files or electronic media. 


\section{A.2.0 Investigation Overview}

Field investigation and sampling activities for the CAU 371 CAI were conducted from January 8, 2009, through February 16, 2010. The following CAI activities were conducted at both CASs within CAU 371:

- Inspected and verified the CAS components identified in the CAIP (NNSA/NSO, 2009b).

- Performed site walkovers to look for biased sampling locations.

- Conducted GWSs and radiological grid surveys (grid surveys conducted at Johnnie Boy only).

- Established sample plots and composite sample aliquot locations.

- Staged TLDs at soil sample plots, background locations, and additional locations of interest.

- Collected and submitted TLDs for analysis.

- Collected soil samples at sample plots and biased sampling locations.

- Submitted soil samples for offsite laboratory analysis.

- Collected GPS coordinates of sample locations, TLD locations, and points of interest.

The investigation and sampling program adhered to the requirements set forth in the CAU 371 CAIP (NNSA/NSO, 2009b). Samples were collected, documented, and analyzed as prescribed in the CAIP. Quality control samples (e.g., duplicate samples) were collected as required by the Industrial Sites QAPP (NNSA/NV, 2002a) and the CAU 371 CAIP.

To facilitate site investigation and the evaluation of DQO decisions for different CSM components, the releases at each CAS were classified into one of the following two categories:

- Primary releases are investigated via a combination of external dose assessment using TLDs and internal dose assessment through the collection and laboratory analysis of surface soil samples. For the purposes of this investigation, surface soils are defined as the top $5 \mathrm{~cm}$ of undisturbed soil. Sampling surface soils to a depth of $5 \mathrm{~cm}$ is appropriate for areas that have not been disturbed since the release because:

1. Numerous studies of soils contaminated by atmospheric deposition following nuclear testing at the NTS have shown that some 90 percent of the radioactivity in undisturbed soil is contained within the top $5 \mathrm{~cm}$ of soil (DRI, 1983 and 1985; Gilbert et al., 1977;

Tamura, 1977).

2. The studies show that as radiological contaminants migrate downward in soils with water infiltration, the contaminant concentration profile exhibits a lognormal distribution with the maximum value remaining near the surface. 
3. Sampling at a greater depth would collect non-contaminated soil along with the contaminated soil. This would serve to dilute the sample, reduce the analytical result (in units of picocuries per gram of sample), and lower the estimate of potential internal dose at the site.

- Other releases include any radionuclide contamination from test activities that is not limited to the surface $5 \mathrm{~cm}$ of soil. This includes radionuclide contaminants that were initially deposited onto the soil surface (as in the primary release category) but have subsequently been displaced through excavation or migration. This category also includes radionuclides that were deposited under mechanisms other than atmospheric deposition. This includes the injection of radionuclides into native material from the nuclear detonation (such as in the Johnnie Boy crater and in the fissure resulting from the Pin Stripe test), the deposition of ejecta piles around the Johnnie Boy crater, and any other chemical or radiological contamination discovered during the investigation through the identification of biasing factors that are not a part of a previously identified release. The depth of radiological contamination from other releases is dependent upon the nature of the release or subsequent movement through excavation or migration. Investigation of other releases was accomplished through measurements of soil radioactivity using a judgmental sampling scheme at depths dependent upon the nature of the release, or by conservative assumptions that radioactivity is present at depth based on process knowledge.

The CASs were investigated by conducting radiological dose measurements (TLDs) and sampling of soils. The data collected at the site that contributes to the decisions made for site closure includes (1) laboratory analysis of the soil samples (i.e., internal dose component of the TED for each sample plot for primary releases, and individual radionuclide results for other releases), (2) analysis of the TLDs (i.e., external dose component of the TED), and (3) radiological walkover surveys of selected areas of the CASs.

The CAU 371 sampling locations were accessible and remained within anticipated spatial boundaries.

Sections A.2.1 through A.2.5 provide the investigation methodology and laboratory analytical information.

\section{A.2.1 Sample Locations}

Investigation locations selected for sampling were based on interpretation of site-specific GWSs and historical investigations (1994 aerial radiological survey [BN, 1999] and RIDP data [DRI, 1985; Gray et al., 2007]); information obtained during site visits; and site conditions as provided in the CAU 371 CAIP (NNSA/NSO, 2009b). Sampling points for each site were selected based on the 
approach provided in the CAIP. The planned biased and random sample locations are discussed in text and represented on figures in the CAIP. Actual environmental sample locations are shown on the figures included in Sections A.3.0 and A.4.0. Some locations were modified slightly from planned positions due to field conditions and observations. In some cases, TLD results determined the need for step-out sampling or additional TLD locations. Sample locations were staked where appropriate and labeled. The corners of each sample plot, judgmental sample location, and CAS points of interest were surveyed with a GPS instrument. Appendix G presents these data in a tabular format. The environmental sample plot locations (Tables A.3-1 and A.4-1) for the CASs in CAU 371 are shown on Figures A.3-2 and A.4-3.

\section{A.2.2 Investigation Activities}

The investigation activities as listed in Section A.2.0 performed at CAU 371 were consistent with the field investigation activities stipulated in the CAU 371 CAIP (NNSA/NSO, 2009b). The investigation strategy allowed the nature and extent of contamination associated with each CAS to be established. The following sections describe the specific investigation activities that took place at CAU 371.

\section{A.2.2.1 Radiological Surveys}

Aerial and ground-level radiological surveys were conducted at both Pin Stripe and Johnnie Boy. Aerial radiological surveys were performed over the area covering both Pin Stripe and Johnnie Boy in 1994 at an altitude of $200 \mathrm{ft}$ with 500-ft flight-line spacing (BN, 1999). An additional aerial radiological survey was conducted over the area containing Johnnie Boy in 2008 at an altitude of $100 \mathrm{ft}$ with 200-ft flight-line spacing (NNSA/NSO, 2009a). These surveys were used to determine the basic distribution (plume) of radionuclides at each site, and aided in the determination of sample plot locations. Results of the aerial radiological surveys are presented in Sections A.3.0 and A.4.0.

Ground-level radiological surveys were performed at both Pin Stripe and Johnnie Boy during the CAI. These radiological surveys were performed to confirm the locations of the fallout plumes (as presented in the aerial radiological surveys), and to identify locations of sample plots and biased sample locations. These radiological surveys were conducted using a Bicron micro-REM per hour dose rate meter or PRM-470 instrument in conjunction with a GPS receiver and datalogger. 


\section{A.2.2.2 Field Screening}

The CAS-specific sections of this document identify the locations where field screening was conducted and how the field-screening levels were used to aid in the selection of samples submitted for analysis. Field-screening results (FSRs) are recorded on SCLs that are retained in project files.

\section{A.2.2.3 Soil Sampling}

Soil sampling for the primary releases at CAU 371 consisted of the collection of surface soil samples (as defined in Section A.2.0) within sample plots. Within each soil sampling plot, four composite samples were collected. Each sample comprised nine randomly located aliquots, resulting in a total of 36 randomly located aliquots collected from each plot. The randomly located aliquot locations were identified using a predetermined random-start, triangular grid pattern. Each aliquot was collected using a "vertical-slice cylinder and bottom-trowel” method. This required the vertical insertion of the 3.5-inch (in.) inside diameter cylinder to a depth of $5 \mathrm{~cm}$, excavation of the outside soil along one side of the cylinder (to permit trowel placement), and horizontal insertion of a trowel along the bottom of the cylinder. This method captured a cylindrical-shaped section of the soil from 0 to $5 \mathrm{~cm}$ bgs. Sampling plots at CAU 371 were selected based on the approach provided in the CAIP. The random sample location coordinates were generated in Visual Sample Plan (VSP) software (PNNL, 2007).

Following collection, each aliquot was carefully placed atop a sieve (\#4 mesh) fitted into a bottom pan (with a plastic bag lining the pan, which limited dust generation during transfer to a sample container [metal can]). Each aliquot was slowly sieved, and oversized material left atop the sieve was returned to the original sample location. Following field screening of the sample, each sample was then transferred to an empty metal can. Each metal can was then sealed with a lid and a locking ring, and then shaken using a paint shaker for three minutes to homogenize the soil.

For sampling other release locations (samples with an " $X$ " designation in the sample number), the sampling was not randomly based but was selected based on biasing factors identified during the GWSs. These other release locations were sampled vertically from the surface to a maximum depth of $30 \mathrm{~cm}$ at 5-cm intervals. These samples were radiologically field screened and the uppermost and lowermost intervals were sent to the laboratory for analysis. When applicable, the interval between 
the upper and lowermost intervals that showed the highest readings at each location were also sent to the laboratory for analysis. These samples were placed in amber glass jars instead of a metal can for shipment to the laboratory.

\section{A.2.2.4 Internal Dose Estimates}

Internal dose was estimated using the radionuclide analytical results from soil samples and the corresponding residual radioactive material guideline (RRMG) (see Appendix C, Attachment C-1). The internal dose RRMG concentration for a particular radionuclide is that concentration in surface soil that would cause an internal dose to a receptor of 25-mrem/yr (under the appropriate exposure scenario) independent of any other radionuclide (assumes that no other radionuclides contribute dose). The internal dose RRMG for each detected radionuclide (in $\mathrm{pCi} / \mathrm{g}$ of soil) was derived using RESRAD computer code (Yu et al., 2001) under the appropriate exposure scenario (see Appendix C, Attachment C-1).

For each surface soil sample in a sampling plot, the radionuclide-specific analytical result was divided by its corresponding internal RRMG (see Appendix C, Attachment C-1, Table 3-2) to yield a fraction of the 25-mrem/yr dose. The fractions for all radionuclides detected in a soil sample were summed to yield a total fraction for that sample. The total fraction was then multiplied by 25 to yield an internal dose estimate (in mrem/yr) at that sample location. A 95 percent UCL was then calculated for the internal dose in a sample plot, using the results of all soil samples collected in that plot (see Table C.1-2).

\section{A.2.2.5 External Dose Measurements}

Thermoluminescent dosimeters (i.e., Panasonic UD-814 TLDs) were installed at both CASs in CAU 371 with the objective of collecting in situ measurements to determine the external radiological dose. The TLDs were placed in background locations around each site at the approximate center of each sample plot at a height of $1 \mathrm{~m}$ (similar to the NTS routine environmental monitoring program). Once retrieved from the field locations, the TLDs were submitted to the Environmental Technical Services group for analysis. The TLD results are discussed in Section A.3.2.1 and Section A.4.2.1 
The TLDs were analyzed using automated TLD readers that are calibrated and maintained by the NTS management and operating (M\&O) contractor. This approach allowed for the use of existing QC procedures for TLD processing. Details of the environmental monitoring TLD program and TLD QC are presented in Section A.6.0. All readings conformed to the approved QC program and are considered representative of the external radiological dose at each location.

The Panasonic UD-814 TLD used in the NTS environmental monitoring program contains four individual elements. The readings from each element are compared as part of the routine QA checks during the TLD processing. External dose at each TLD location is then determined using the readings from TLD elements 2, 3, and 4. Element 1 is designed to measure dose to the skin and is not relevant to the determination of the external dose for the purpose of this investigation.

Estimates of external dose, in mrem/IA-yr, at the CAU 371 sites are presented as net values (e.g., the exposure from control TLDs and from the natural or "field" background has been subtracted from the raw result). The control TLDs measured the amount of dose received by the TLDs before being deployed in the field. The "field" background TLDs measured the amount of dose received by TLDs in areas unaffected by the CASs. A 95 percent UCL was then calculated for each TLD location using the results from the three TLD elements described in Section A.2.2.5.

\section{A.2.3 Total Effective Dose}

The probabilistic sampling design as described in the CAIP for CAU 371 (NNSA/NSO, 2009b) requires comparing the 95 percent UCL of the TED at each sample plot to the FAL to determine whether a COC is present. The average TED calculated from sample results is an estimate of the true (unknown) TED. It is uncertain how well the average TED represents the true TED. If an average TED were directly compared to the FAL, any significant difference between the true TED and the sample TED could lead to decision errors. To reduce the probability of a false negative decision error, a conservative estimate of the true TED is used to compare to the FAL. This conservative estimate of the true TED was calculated as the 95 percent UCLs of the average TED calculated from the respective individual TEDs associated with each composite sample (see Tables A.3-9 and A.4-8). By definition, there will be a 95 percent probability that the true TED is less than the 95 percent UCL of the calculated average TED. 


\section{A.2.4 Laboratory Analytical Information}

Radiological analyses of the collected soil samples were performed by ALS Laboratory Group, of Fort Collins, Colorado. The analytical suites and laboratory analytical methods used to analyze investigation samples are listed in Table A.2-1. Analytical results are reported in this appendix if

Table A.2-1

Laboratory Analyses and Methods, CAU 371 Investigation Samples $^{\text {a }}$

\begin{tabular}{|c|c|}
\hline Analysis & Analytical Method ${ }^{b}$ \\
\hline Isotopic U & Aqueous/Non-aqueous - DOE EML HASL-300 U-02-RC \\
\hline Isotopic Pu & $\begin{array}{c}\text { Aqueous - DOE EML HASL-300 Pu-10-RC } \\
\text { Non-aqueous - DOE EML HASL-300' Pu-02-RC }\end{array}$ \\
\hline Isotopic Am & $\begin{array}{c}\text { Aqueous - DOE EML HASL-300' Am-03-RC } \\
\text { Non-aqueous - DOE EML HASL-300d Am-01-RC }\end{array}$ \\
\hline Gamma Spectroscopy & $\begin{array}{c}\text { Aqueous - EPA 901.1 } \\
\text { Non-aqueous - DOE EML HASL-300 Ga-01-R }\end{array}$ \\
\hline Sr-90 & $\begin{array}{c}\text { Aqueous - EPA 905. } 0^{d} \\
\text { Non-aqueous - DOE EML HASL-300' Sr-02-RC }\end{array}$ \\
\hline
\end{tabular}

anvestigation samples include both environmental and associated QC samples.

${ }^{\text {b}}$ The most current EPA, DOE, ASTM, NIOSH, or equivalent accepted analytical method may be used, including approved Laboratory Standard Operating Procedures (NNES, 2009).

${ }^{\mathrm{c}}$ The Procedures Manual of the Environmental Measurements Laboratory (DOE, 1997).

${ }^{\mathrm{d}}$ Prescribed Procedures for Measurement of Radioactivity in Drinking Water (EPA, 1980).

ASTM = American Society for Testing and Materials $\mathrm{EML}=$ Environmental Measurements Laboratory $\mathrm{EPA}=$ U.S. Environmental Protection Agency
HASL = Health and Safety Laboratory $\mathrm{NIOSH}=$ National Institute for Occupational Safety and Health

they were detected above the minimum detectable concentrations (MDCs). The complete laboratory data packages are available in the project files.

Validated analytical data for CAU 371 investigation samples have been compiled and evaluated to confirm the presence of contamination and to define the extent of contamination. The validated results of the radiochemical analyses were evaluated for only those radionuclides that contribute to an internal dose (see Appendix C). The analytical results for each CAS are presented in Sections A.3.0 and A.4.0.

The analytical parameters were selected through the application of site process knowledge as described in the CAIP (NNSA/NSO, 2009b). 


\section{A.2.5 Comparison to Action Levels}

The PALs and FALs are based on an annual dose limit of $25 \mathrm{mrem} / \mathrm{yr}$. This dose limit is specific to the annual dose a receptor could potentially receive from a CAU 371 release. As such, it is dependent upon the cumulative annual hours of exposure to site contamination. The PA3Ls were established in the CAIP (NNSA/NSO, 2009b) based on a dose limit of $25 \mathrm{mrem} / \mathrm{yr}$ over an annual exposure time of 2,250 hours (i.e., the Industrial Area exposure scenario that a site worker would be exposed to site contamination for 225 day/yr and $10 \mathrm{hr} /$ day). The FALs were established in Appendix C based on a dose limit of 25 mrem/yr over an annual exposure time of 336 hours (i.e., the Remote Work Area exposure scenario that a site worker would be exposed to site contamination for $42 \mathrm{day} / \mathrm{yr}$ and $8 \mathrm{hr} /$ day).

For the establishment of the FALs presented in Appendix C, a review of the current and projected use of both sites determined that workers may only be present at these sites on a limited basis (see Section C.1.10) and it is not reasonable to assume that any worker would be present at this site on a full-time basis. The actual current and projected use for these CASs assumes that workers may be present at these sites only occasionally on a very limited basis (DOE/NV, 1996). This is consistent with the determination in the CAU 371 DQOs that these sites fit the Occasional Use Area exposure scenario (as listed in Section 3.1.1 of the CAU 371 CAIP [NNSA/NSO, 2009b]). This exposure scenario assumes workers may use the site occasionally for intermittent or short-term activities (i.e., equivalent to $8 \mathrm{hr} / \mathrm{day}, 10$ day/yr, for 5 years).

Using the maximum dose measured at any Pin Stripe surface location, a receptor would have to be exposed to the location of maximum dose for 922 hours to receive a dose of 25 mrem. Similarly, based on the maximum dose measured at any Johnnie Boy surface location, a receptor would have to be exposed to the location of maximum dose for 990 hours to receive a dose of $25 \mathrm{mrem}$. Based on the required exposure times to potentially receive a $25 \mathrm{mrem} / \mathrm{yr}$ dose, a receptor under the more conservative exposure scenario of Remote Work Area (336 hr/yr) could not exceed the 25-mrem/yr dose limit at either CAS. Therefore, it was decided to base the FALs on the Remote Work Area exposure scenario.

Results for both the primary releases and other releases are presented in Sections A.3.2 and A.4.2. The primary release results are reported as doses that are comparable to the dose-based FAL as 
established in Appendix C. For the other releases, the results are reported as individual radionuclide concentrations that are comparable to the individual radionuclide FALs as established in Appendix C. Results that are equal to or greater than FALs are identified by bold text in the CAS-specific results tables (see Sections A.3.0 and A.4.0).

A COC is defined as any contaminant present in environmental media exceeding a FAL. A COC may also be defined as a contaminant that, in combination with other like contaminants, is determined to jointly pose an unacceptable risk based on a multiple constituent analysis (NNSA/NSO, 2006). If COCs are present, corrective action must be considered for the CAS. 


\section{A.3.0 CAS 11-23-05, Pin Stripe Contamination Area}

Corrective Action Site 11-23-05 is located in the southeastern portion of Area 11 of the NTS, north of the Area 5 RWMS. The CAS consists of a release of radioactive material to the soil surface as a result of the venting of radiological gases from a fissure during the Pin Stripe weapons-effects test. Additional detail on the history of Pin Stripe is provided in the CAIP (NNSA/NSO, 2009b).

\section{A.3.1 Corrective Action Investigations}

A total of 23 environmental samples (20 primary release samples and 2 field duplicates [FDs] from 5 sample plots and one other release sample from the fissure) were collected during investigation activities at Pin Stripe. All samples were analyzed for gamma spectroscopy; Sr-90; and isotopic U, $\mathrm{Pu}$, and Am. The sample identifications (IDs), locations, and types are listed in Table A.3-1. The specific CAI activities conducted to satisfy the CAIP requirements at this CAS (NNSA/NSO, 2009b) are described in the following sections.

Table A.3-1

Samples Collected at Pin Stripe

(Page 1 of 2)

\begin{tabular}{|c|c|c|c|c|}
\hline $\begin{array}{l}\text { Sample } \\
\text { Plot or } \\
\text { Location }\end{array}$ & $\begin{array}{l}\text { Sample } \\
\text { Number }\end{array}$ & $\begin{array}{c}\text { Depth } \\
\text { (cm bgs) }\end{array}$ & Matrix & Purpose \\
\hline \multirow{5}{*}{ AA } & 371AA01 & $0.0-5.0$ & Soil & Environmental \\
\hline & 371AA02 & $0.0-5.0$ & Soil & FD of \#371AA01 \\
\hline & 371AA03 & $0.0-5.0$ & Soil & Environmental \\
\hline & 371AA04 & $0.0-5.0$ & Soil & Environmental \\
\hline & 371AA05 & $0.0-5.0$ & Soil & Environmental \\
\hline \multirow{4}{*}{$A B$} & 371AB01 & $0.0-5.0$ & Soil & Environmental \\
\hline & 371AB02 & $0.0-5.0$ & Soil & Environmental \\
\hline & 371AB03 & $0.0-5.0$ & Soil & Environmental \\
\hline & 371AB04 & $0.0-5.0$ & Soil & Environmental \\
\hline \multirow{4}{*}{$A C$} & 371AC01 & $0.0-5.0$ & Soil & Environmental \\
\hline & 371AC02 & $0.0-5.0$ & Soil & Environmental \\
\hline & 371AC03 & $0.0-5.0$ & Soil & Environmental \\
\hline & $371 \mathrm{AC} 04$ & $0.0-5.0$ & Soil & Environmental, Full Lab QC \\
\hline
\end{tabular}


Table A.3-1

\section{Samples Collected at Pin Stripe}

(Page 2 of 2)

\begin{tabular}{|c|c|c|c|c||}
\hline $\begin{array}{c}\text { Sample } \\
\text { Plot or } \\
\text { Location }\end{array}$ & $\begin{array}{c}\text { Sample } \\
\text { Number }\end{array}$ & $\begin{array}{c}\text { Depth } \\
\text { (cm bgs) }\end{array}$ & Matrix & Purpose \\
\hline \hline \multirow{4}{*}{ AE } & $371 \mathrm{AE01}$ & $0.0-5.0$ & Soil & Environmental \\
\cline { 2 - 6 } & $371 \mathrm{AE} 02$ & $0.0-5.0$ & Soil & FD of \#371AE01 \\
\cline { 2 - 6 } & $371 \mathrm{AE} 03$ & $0.0-5.0$ & Soil & Environmental \\
\cline { 2 - 6 } & $371 \mathrm{AE} 04$ & $0.0-5.0$ & Soil & Environmental \\
\cline { 2 - 6 } & $371 \mathrm{AE} 05$ & $0.0-5.0$ & Soil & Environmental \\
\hline \multirow{3}{*}{$\mathrm{AF}$} & $371 \mathrm{AF} 01$ & $0.0-5.0$ & Soil & Environmental \\
\cline { 2 - 6 } & $371 \mathrm{AF} 02$ & $0.0-5.0$ & Soil & Environmental, Full Lab QC \\
\cline { 2 - 6 } & $371 \mathrm{AF} 03$ & $0.0-5.0$ & Soil & Environmental \\
\cline { 2 - 6 } & $371 \mathrm{AF} 04$ & $0.0-5.0$ & Soil & Environmental \\
\hline A01 & $371 \mathrm{AX01}$ & $25.0-30.0$ & Soil & Environmental \\
\hline
\end{tabular}

\section{A.3.1.1 Visual Inspections}

Visual inspections of Pin Stripe were conducted over the course of the field investigation including site walks, sampling efforts, and radiological surveys. While walking over the site, the presence of scattered debris were identified and noted.

\section{A.3.1.2 Radiological Surveys}

Global Positioning System-assisted GWSs were performed at Pin Stripe during the CAI. The GWSs were conducted in and surrounding the crater area and in the area north of the crater area to identify the locations of the highest radiological readings and to confirm the location of the fallout plume. The results of the GWS showed that the highest gamma radiation readings are present in the area of the fissure, and confirmed that the fallout plume was positioned as expected. Therefore, the only biased sample for an other release was collected at the fissure. Figure A.3-1 presents a graphic representation of the data from the GWS (displayed as the number of standard deviations above the mean). Three $100-\mathrm{m}^{2}$ sample plots were then established within the areas containing the highest anomalous readings as detected during the GWSs (Figure A.3-1). Composite samples were collected at these plots. 


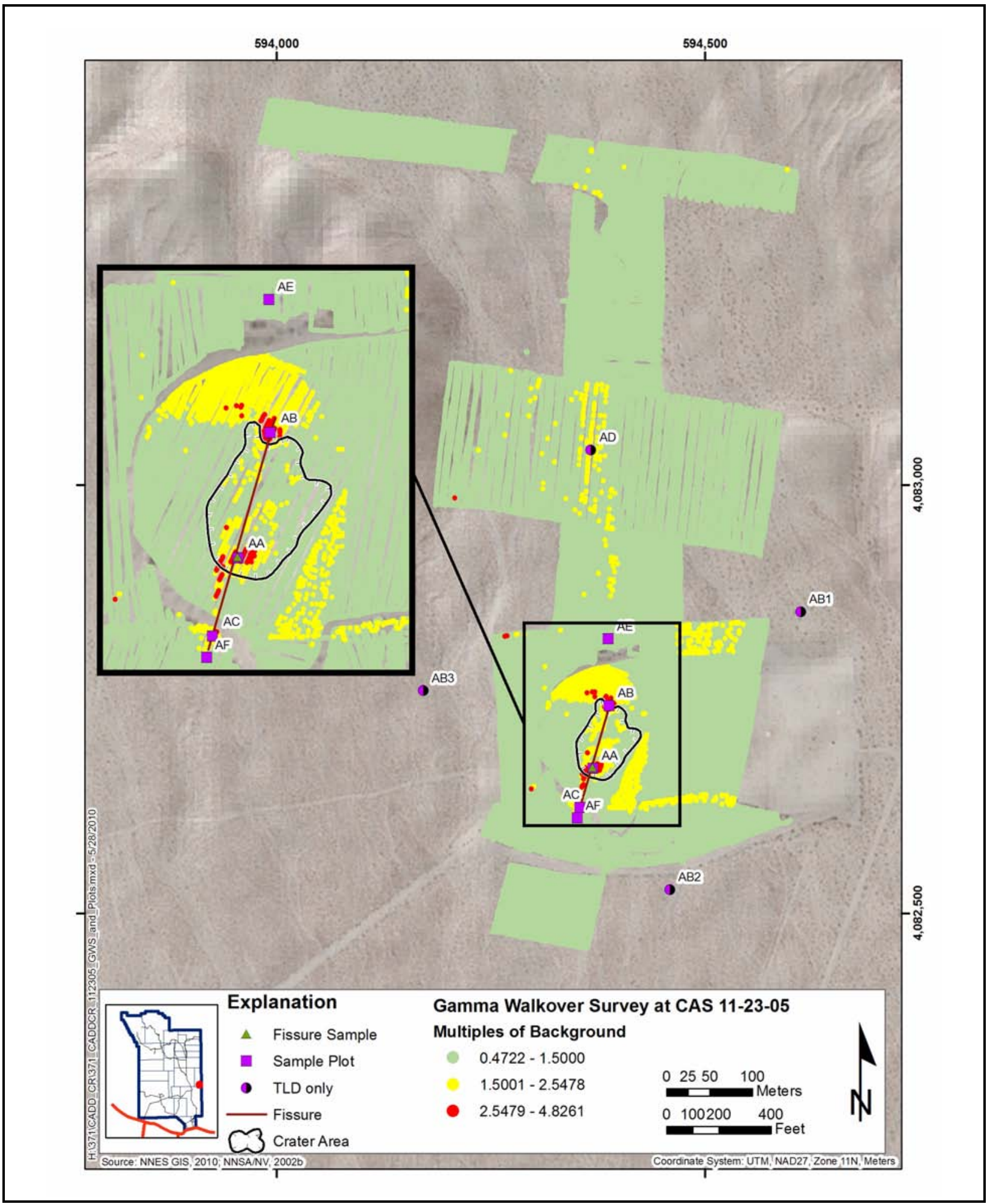

Figure A.3-1

Gamma Walkover Surveys of Selected Locations at Pin Stripe 


\section{A.3.1.3 TLD Measurements}

The TLDs were installed at nine locations (AA through AF and AB1 through AB3) at Pin Stripe to measure external doses (Figure A.3-2). Three of these TLDs (AB1, AB2, and AB3) were placed to measure "field" background. The TLDs listed in Table A.3-2 were used at the Pin Stripe site to measure external doses. Sampling plots were placed at all other TLD locations (except TLD location $\mathrm{AD}$ ). Location $\mathrm{AD}$ was placed to measure the external dose within the area impacted by the plume to the north of GZ. All TLDs were included in the routine quarterly read of the NTS environmental monitoring TLDs. Details of the environmental monitoring TLD program and TLD QC are presented in Section A.6.0. The TLD results are discussed in Section A.3.2.1. See Figure A.3-2 for TLD locations.

Table A.3-2

TLDs at Pin Stripe

\begin{tabular}{|c|c|c|c|c|}
\hline TLD Location & TLD No. & Date Placed & Date Removed & Purpose \\
\hline \hline$A A$ & 4432 & $06 / 18 / 2009$ & $09 / 21 / 2009$ & Sample plot \\
\hline$A B$ & 5133 & $06 / 18 / 2009$ & $09 / 21 / 2009$ & Sample plot \\
\hline$A C$ & 4314 & $06 / 18 / 2009$ & $09 / 21 / 2009$ & Sample plot \\
\hline$A D$ & 4336 & $06 / 18 / 2009$ & $09 / 21 / 2009$ & TLD only \\
\hline$A E$ & 4479 & $08 / 07 / 2009$ & $09 / 21 / 2009$ & Sample plot \\
\hline$A F$ & 5152 & $08 / 07 / 2009$ & $09 / 21 / 2009$ & Sample plot \\
\hline$A B 1$ & 5024 & $06 / 18 / 2009$ & $09 / 21 / 2009$ & Background TLD location \\
\hline$A B 2$ & 5008 & $06 / 18 / 2009$ & $09 / 21 / 2009$ & Background TLD location \\
\hline$A B 3$ & 4785 & $06 / 18 / 2009$ & $09 / 21 / 2009$ & Background TLD location \\
\hline
\end{tabular}

\section{A.3.1.4 Sample Collection}

Sampling activities at Pin Stripe for the determination of internal dose at the sample plots consisted of the collection of 22 primary release composite surface soil (defined in Section A.2.0) samples (which included 2 FDs) at 5 plots (AA, AB, AC, AE, and AF). The plot locations were established at the areas of the anomalous radiological readings as detected during the GWSs conducted at the site. An other release sample (Location A01 within plot AA) was collected at a depth of 25 to $30 \mathrm{~cm}$ at a location believed to be within the fissure (as indicated by of the highest GWS value). Final sample locations (Table A.3-1) are shown on Figure A.3-2. 


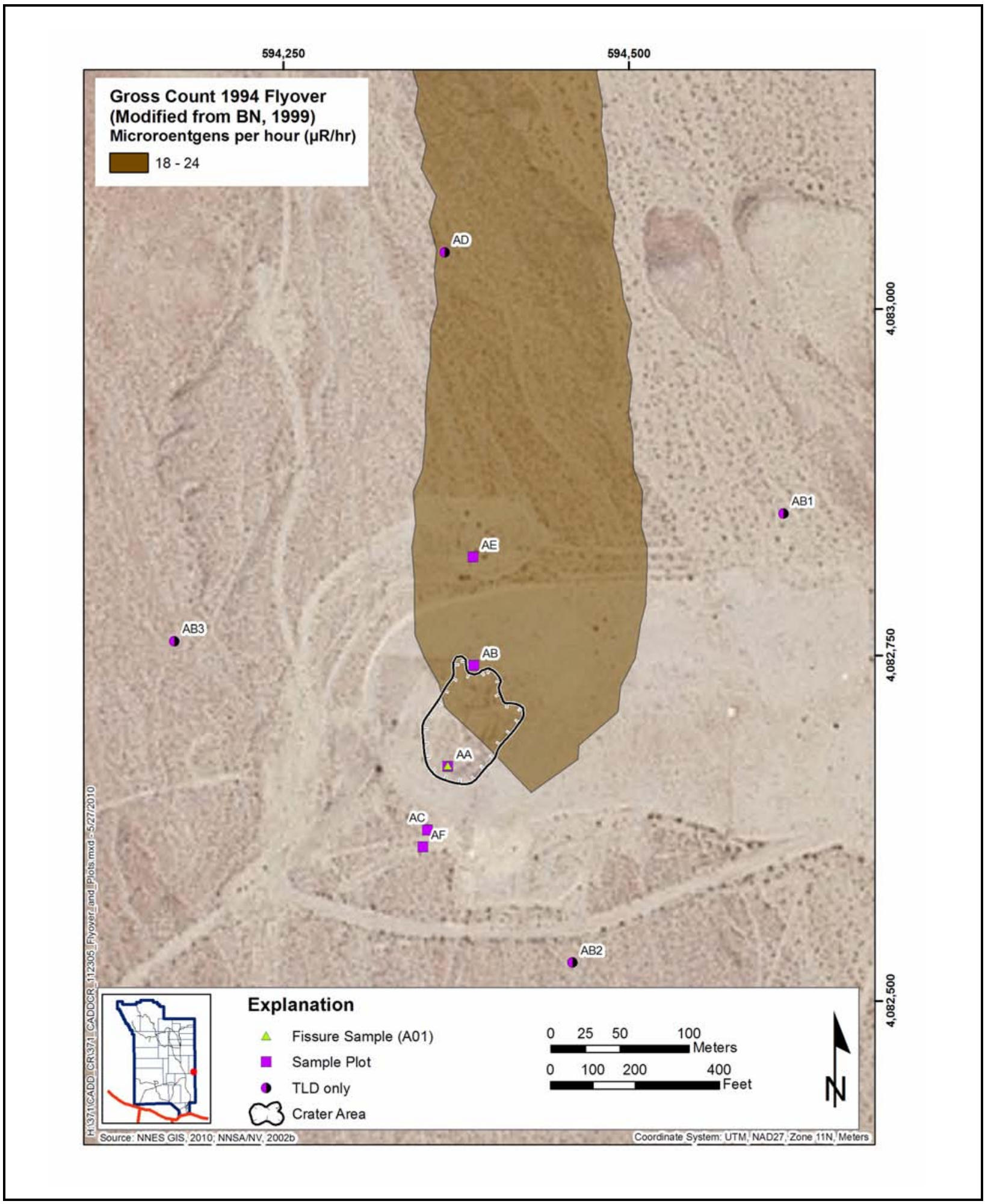

Figure A.3-2

Pin Stripe Sample and TLD Locations 


\section{A.3.1.5 Deviations}

No deviations to the CAU 371 CAIP (NNSA/NSO, 2009b) were noted.

\section{A.3.2 Investigation Results}

The following sections provide analytical and computational results for samples collected for investigation of the primary and other releases at Pin Stripe as outlined in the CAIP (NNSA/NSO, 2009b). Samples were analyzed according to the CAIP-specified analytical methods, which included analysis for gamma spectroscopy; Sr-90; and isotopic U, Pu, and Am. The analytical parameters and laboratory methods used during this investigation were discussed in Section A.2.0 and are listed in Table A.2-1.

The internal dose calculated from soil sample results, and the external dose calculated from TLD measurements were combined to determine TED at each primary release sample location. Results from the TLD locations are summarized in Section A.3.2.1. Results of internal dose calculated from analytical results of composite soil samples collected from each sample plot are summarized in Section A.3.2.2. The combined estimated radiological dose for each sample plot, expressed as the TED, is summarized in Section A.3.2.3. Radiological results for the other release (i.e., fissure sample at 25 to $30 \mathrm{~cm}$ bgs) are summarized in Section A.3.2.4.

The primary release results are reported as doses that are comparable to the dose-based FAL of $25 \mathrm{mrem} / \mathrm{RW}$-yr. For the other releases, the results are reported as individual radionuclide concentrations that are comparable to the individual radionuclide FALs based on $25 \mathrm{mrem} / \mathrm{RW}$-yr. Results that are equal to or greater than FALs are identified by bold text in the results tables.

\section{A.3.2.1 External Radiological Dose Measurements}

Measurements for the external dose was calculated for the Industrial Area exposure scenario and then scaled (based on exposure duration) to the Remote Work Area and Occasional Use Area exposure scenarios for each TLD location. The values for the individual elements in each TLD and the average TLD values for Pin Stripe are presented in Table A.3-3. The 95 percent UCL of external dose for each exposure scenario is presented in Table A.3-4. 
Table A.3-3

External Dose Measurements at Pin Stripe Sample Locations

\begin{tabular}{|c|c|c|c|c|c||}
\hline Location & $\begin{array}{c}\text { Element 2 } \\
\text { (mrem/IA-yr) }\end{array}$ & $\begin{array}{c}\text { Element 3 } \\
\text { (mrem/IA-yr) }\end{array}$ & $\begin{array}{c}\text { Element 4 } \\
\text { (mrem/IA-yr) }\end{array}$ & $\begin{array}{c}\text { Average TLD } \\
\text { Value } \\
\text { (mrem/IA-yr) }\end{array}$ & $\begin{array}{c}\text { 95\% UCL of } \\
\text { TLD }\end{array}$ \\
\hline \hline $\mathrm{AA}$ & $\mathbf{6 8 . 1}$ & $\mathbf{5 8 . 2}$ & $\mathbf{5 6 . 2}$ & $\mathbf{6 0 . 8}$ & $\mathbf{7 1 . 5}$ \\
\hline $\mathrm{AB}$ & $\mathbf{4 2 . 6}$ & $\mathbf{3 2 . 9}$ & $\mathbf{3 2 . 1}$ & $\mathbf{3 5 . 9}$ & $\mathbf{4 5 . 7}$ \\
\hline $\mathrm{AC}$ & $\mathbf{2 8 . 1}$ & 21.0 & 19.7 & 22.9 & $\mathbf{3 0 . 6}$ \\
\hline $\mathrm{AD}$ & 9.1 & 2.8 & 1.9 & 4.6 & 11.2 \\
\hline $\mathrm{AE}$ & 10.4 & 2.0 & 3.3 & 5.2 & 12.8 \\
\hline $\mathrm{AF}$ & 13.9 & 7.0 & 5.2 & 8.7 & 16.5 \\
\hline
\end{tabular}

Bold indicates the values exceeding $25 \mathrm{mrem} / \mathrm{yr}$.

Table A.3-4

Pin Stripe 95\% UCL External Dose for Each Exposure Scenario

\begin{tabular}{|c|c|c|c|}
\hline $\begin{array}{c}\text { Plot or } \\
\text { Location }\end{array}$ & $\begin{array}{c}\text { Industrial Area } \\
\text { (mrem/IA-yr) }\end{array}$ & $\begin{array}{c}\text { Remote Work Area } \\
\text { (mrem/RW-yr) }\end{array}$ & $\begin{array}{c}\text { Occasional Use Area } \\
\text { (mrem/OU-yr) }\end{array}$ \\
\hline \hline $\mathrm{AA}$ & $\mathbf{7 1 . 5}$ & 10.7 & 2.5 \\
\hline $\mathrm{AB}$ & $\mathbf{4 5 . 7}$ & 6.8 & 1.6 \\
\hline $\mathrm{AC}$ & $\mathbf{3 0 . 6}$ & 4.6 & 0.4 \\
\hline $\mathrm{AD}$ & 11.2 & 1.7 & 0.5 \\
\hline $\mathrm{AE}$ & 12.8 & 1.9 & 0.6 \\
\hline $\mathrm{AF}$ & 16.5 & 2.5 & 1.1 \\
\hline
\end{tabular}

Bold indicates the values exceeding $25 \mathrm{mrem} / \mathrm{yr}$.

\section{A.3.2.2 Internal Radiological Dose Estimations}

Estimates for the internal dose that a receptor would receive at each sample plot at Pin Stripe were determined through the evaluation of the soil sample analytical results using the RESRAD computer code (Yu et al., 2001) (see Appendix C, Attachment C-1). Results are presented in Table A.3-5. As shown in Table A.3-6, the contribution to TED from internal dose is not significant. For the location of the maximum internal dose (plot $A B$ ), internal dose was less than 0.2 percent of the TED. The average internal dose for each exposure scenario is presented in Table A.3-7. The 95 percent UCL of internal dose for each exposure scenario is presented in Table A.3-8.

Data tables listing the analytical results for individual radionuclides in each composite plot sample are presented in Appendix F. 
Table A.3-5

Internal Dose Estimations at Pin Stripe Sample Plots (mrem/IA-yr)

\begin{tabular}{|c|c|c|c|c|c|c|c||}
\hline Plot & Sample 1 & Sample 2 & Sample 3 & Sample 4 & Sample 5 & $\begin{array}{c}\text { Average for } \\
\text { Sample Plot }\end{array}$ & $\begin{array}{c}\text { 95\% UCL for } \\
\text { Sample Plot }\end{array}$ \\
\hline \hline $\mathrm{AA}$ & 0.031 & 0.022 & 0.023 & 0.025 & 0.022 & 0.024 & 0.028 \\
\hline $\mathrm{AB}$ & 0.034 & 0.06 & 0.067 & 0.045 & -- & $\mathbf{0 . 0 5 1}$ & $\mathbf{0 . 0 6 8}$ \\
\hline $\mathrm{AC}$ & 0.035 & 0.05 & 0.047 & 0.053 & -- & 0.046 & 0.055 \\
\hline $\mathrm{AE}$ & 0.022 & 0.023 & 0.022 & 0.023 & 0.024 & 0.023 & 0.024 \\
\hline $\mathrm{AF}$ & 0.021 & 0.021 & 0.020 & 0.021 & -- & 0.021 & 0.021 \\
\hline
\end{tabular}

-- = Duplicate not taken for this plot.

Maximum internal dose value bolded.

Table A.3-6

Pin Stripe Ratio of Average Internal Dose to External Dose at Each Plot (mrem/RW-yr)

\begin{tabular}{|c|c|c|c|c|}
\hline Plot & $\begin{array}{c}\text { Average Internal } \\
\text { Dose }\end{array}$ & $\begin{array}{c}\text { Average External } \\
\text { Dose }\end{array}$ & $\begin{array}{c}\text { Average Total } \\
\text { Dose }\end{array}$ & \% TED \\
\hline \hline$A A$ & 0.004 & 9.08 & 9.09 & 0.05 \\
\hline$A B$ & 0.009 & 5.36 & 5.37 & 0.17 \\
\hline$A C$ & 0.008 & 3.43 & 3.43 & 0.24 \\
\hline$A E$ & 0.004 & 0.78 & 0.79 & 0.27 \\
\hline$A F$ & 0.004 & 1.30 & 1.31 & 0.50 \\
\hline
\end{tabular}

Table A.3-7

Pin Stripe Average Internal Dose for Each Exposure Scenario

\begin{tabular}{|c|c|c|c|}
\hline $\begin{array}{c}\text { Plot or } \\
\text { Location }\end{array}$ & $\begin{array}{c}\text { Industrial Area } \\
\text { (mrem/IA-yr) }\end{array}$ & $\begin{array}{c}\text { Remote Work Area } \\
\text { (mrem/RW-yr) }\end{array}$ & $\begin{array}{c}\text { Occasional Use Area } \\
\text { (mrem/OU-yr) }\end{array}$ \\
\hline \hline $\mathrm{AA}$ & 0.024 & 0.004 & 0.001 \\
\hline $\mathrm{AB}$ & 0.051 & 0.009 & 0.003 \\
\hline $\mathrm{AC}$ & 0.046 & 0.008 & 0.003 \\
\hline $\mathrm{AE}$ & 0.023 & 0.004 & 0.001 \\
\hline $\mathrm{AF}$ & 0.021 & 0.004 & 0.001 \\
\hline
\end{tabular}

\section{A.3.2.3 Total Effective Dose}

As the contribution of internal dose to the TED was not a significant percent of the total dose (Table A.3-6), it was conservatively determined to use the maximum internal dose estimate at Pin Stripe for the calculation of all TED values. The average TED for each TLD location was 
Table A.3-8

Pin Stripe 95\% UCL Internal Dose for Each Exposure Scenario

\begin{tabular}{|c|c|c|c|}
\hline $\begin{array}{c}\text { Plot or } \\
\text { Location }\end{array}$ & $\begin{array}{c}\text { Industrial Area } \\
\text { (mrem/IA-yr) }\end{array}$ & $\begin{array}{c}\text { Remote Work Area } \\
\text { (mrem/RW-yr) }\end{array}$ & $\begin{array}{c}\text { Occasional Use Area } \\
\text { (mrem/OU-yr) }\end{array}$ \\
\hline \hline $\mathrm{AA}$ & 0.028 & 0.005 & 0.002 \\
\hline $\mathrm{AB}$ & 0.068 & 0.012 & 0.004 \\
\hline $\mathrm{AC}$ & 0.055 & 0.01 & 0.003 \\
\hline $\mathrm{AE}$ & 0.024 & 0.004 & 0.001 \\
\hline $\mathrm{AF}$ & 0.021 & 0.004 & 0.001 \\
\hline
\end{tabular}

calculated by adding the average external dose (TLD) measurement to the highest internal dose estimate (from plot AB) (Figure A.3-3). Values for both the average TED and the 95 percent UCL of the TED for the Industrial Area, Remote Work Area, and Occasional Use Area exposure scenarios were determined and are presented in Table A.3-9.

The results for sample plots $\mathrm{AA}, \mathrm{AB}$, and $\mathrm{AC}$ (which were placed in the location of the fissure) and sample plots $\mathrm{AE}$ and $\mathrm{AF}$ (which were established in areas of anomalous readings identified during the GWSs; Section A.3.1.2) did not exceed the 25-mrem/RW-yr FAL (Figure A.3-4).

\section{A.3.2.4 Results for Other Release at Pin Stripe}

Analytical results exceeding MDCs from the sample collected at the depth of 25 to $30 \mathrm{~cm}$ bgs near the TLD location within Plot AA (for the purpose of verifying the location of the fissure) are presented in the following sections.

\section{A.3.2.4.1 Gamma-Emitting Radionuclides}

Analytical results for gamma-emitting radionuclides in the environmental sample collected at the location of the fissure that were detected above MDCs are presented in Table A.3-10. The radionuclide Cs-137 was detected at an activity (425 pCi/g) that exceeded the PAL (12.7 pCi/g) in the sample taken at the depth of 25 to $30 \mathrm{~cm}$ bgs at location A01. However, it did not exceed the FAL (487.4 pCi/g). 


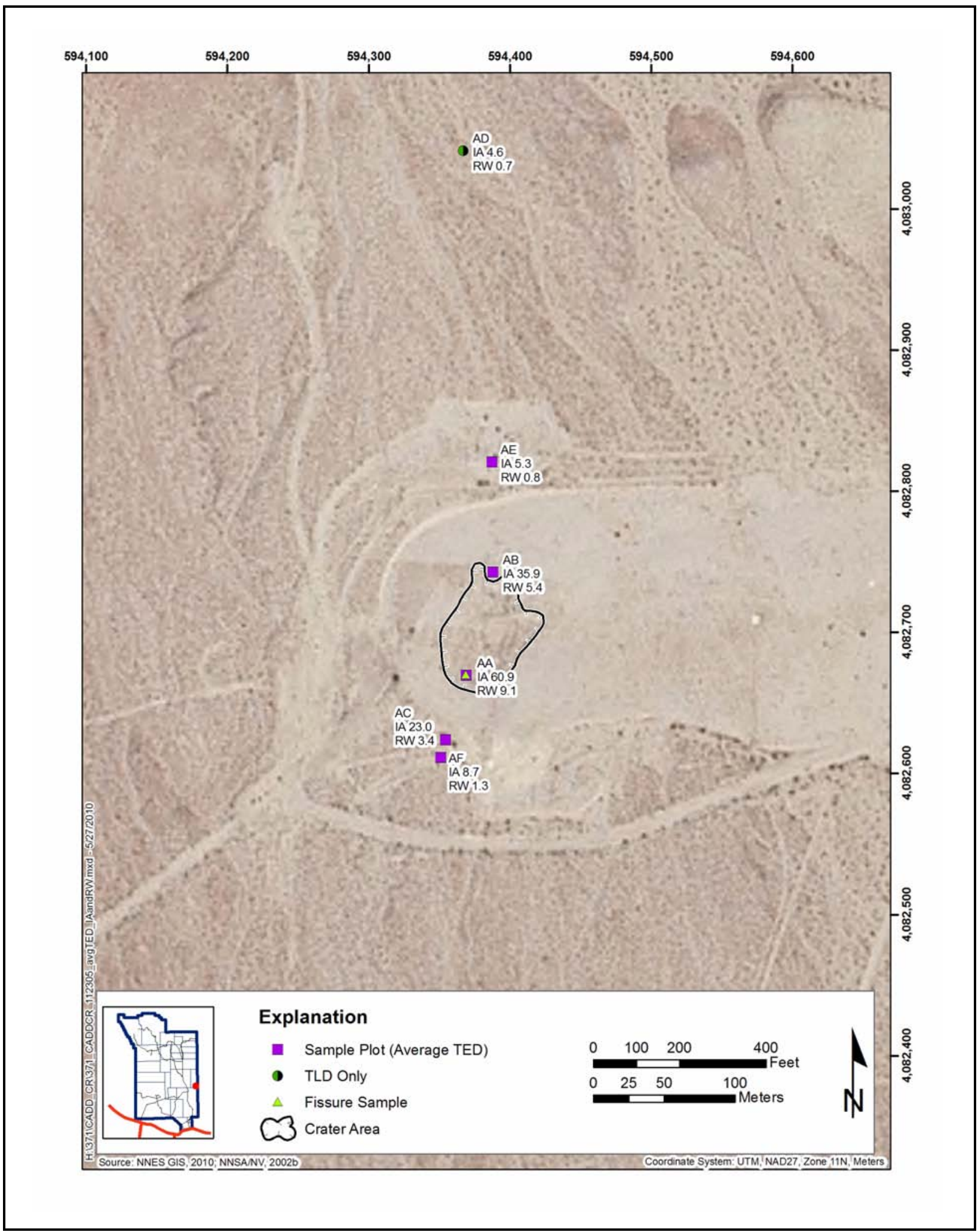

Figure A.3-3

Average TED at Pin Stripe 
Table A.3-9

\section{Pin Stripe TED at Sample Locations (mrem/yr)}

\begin{tabular}{|c|c|c|c|c|c|c|}
\hline \multirow{2}{*}{$\begin{array}{c}\text { Plot or } \\
\text { Location }\end{array}$} & \multicolumn{2}{|c|}{$\begin{array}{c}\text { Industrial Area } \\
\text { Average } \\
\text { TED }\end{array}$} & $\begin{array}{c}\text { 95\% UCL of } \\
\text { TED }\end{array}$ & $\begin{array}{c}\text { Average } \\
\text { TED }\end{array}$ & $\begin{array}{c}\text { 95\% UCL of } \\
\text { TED }\end{array}$ & \multicolumn{2}{c|}{$\begin{array}{c}\text { Average } \\
\text { TED }\end{array}$} & $\begin{array}{c}\text { O5\% UCL of } \\
\text { TED }\end{array}$ \\
\hline \hline $\mathrm{AA}$ & $\mathbf{6 0 . 9}$ & $\mathbf{7 1 . 6}$ & 9.09 & 10.7 & 2.17 & 2.55 \\
\hline $\mathrm{AB}$ & $\mathbf{3 5 . 9}$ & $\mathbf{4 5 . 8}$ & 5.37 & 6.8 & 1.28 & 1.63 \\
\hline $\mathrm{AC}$ & 23.0 & $\mathbf{3 0 . 6}$ & 3.43 & 4.6 & 0.82 & 1.09 \\
\hline $\mathrm{AD}$ & 4.6 & 11.2 & 0.69 & 1.7 & 0.17 & 0.40 \\
\hline $\mathrm{AE}$ & 5.3 & 12.9 & 0.79 & 1.9 & 0.19 & 0.46 \\
\hline $\mathrm{AF}$ & 8.7 & 16.5 & 1.31 & 2.5 & 0.31 & 0.59 \\
\hline
\end{tabular}

Bold indicates the values exceeding $25 \mathrm{mrem} / \mathrm{yr}$.

\section{A.3.2.4.2 Isotopic Radionuclides}

Analytical results detected above MDCs for isotopic radionuclides in the environmental sample collected at the location of the fissure are presented in Table A.3-10. No Sr-90 or isotopic U, Pu, or Am results exceeded their respective PALs.

\section{A.3.3 Nature and Extent of Contamination}

Based on the analytical results for soil samples collected within Pin Stripe, no surface COCs were identified at this CAS. However, it is assumed that subsurface contamination that is present in the fissure exceeds the FAL. Therefore, a corrective action is required. The selected corrective action (based on the corrective action evaluation presented in Appendix E) for the subsurface contamination is closure in place with a UR. A UR was established that encompasses the area of the Pin Stripe subsidence crater as well as the identified surface expression of the fissure (based on GWS results) that extends south of the crater area (Figure A.3-5).

As a BMP, it was determined to identify and administratively use restrict any area where the TED exceeds 25 mrem/IA-yr to prevent any future industrial land use activities that would cause a full-time industrial site worker to be exposed to contamination at this site. At Pin Stripe, the TED from surface soils exceeded a dose of 25 mrem under the Industrial Area scenario at plots AA, AB, and AC. These areas exceeding the 25-mrem/IA-yr dose are encompassed by the UR, and thus no additional protective measures were needed. 


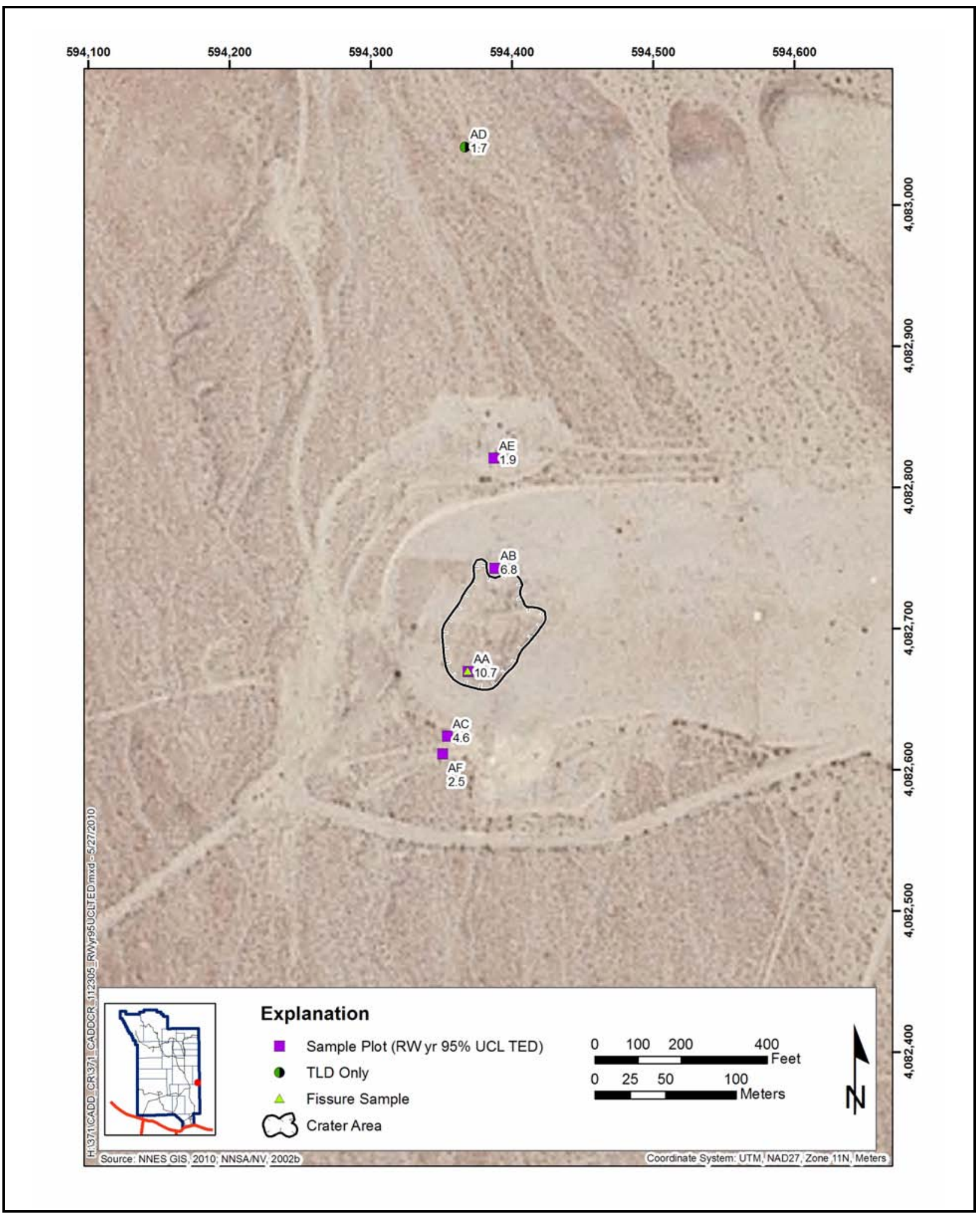

Figure A.3-4

95\% UCL of the TED at Pin Stripe 
Table A.3-10

Sample Results above MDCs at Pin Stripe Other Release

\begin{tabular}{|c|c|c|c|c|c|c|c|c|c|c|c|c|c|}
\hline \multirow[b]{2}{*}{$\begin{array}{l}\text { Sample } \\
\text { Location }\end{array}$} & \multirow[b]{2}{*}{$\begin{array}{l}\text { Sample } \\
\text { Number }\end{array}$} & \multirow[b]{2}{*}{$\begin{array}{c}\text { Depth } \\
\text { (cm bgs) }\end{array}$} & \multicolumn{10}{|c|}{ cOPCs (pCi/g) } & \multirow[b]{2}{*}{ 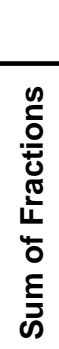 } \\
\hline & & & 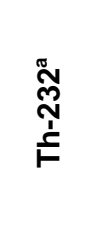 & 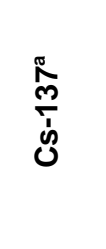 & 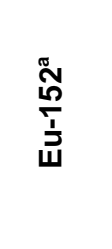 & 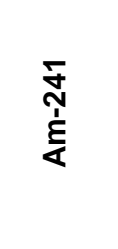 & $\begin{array}{l}\infty \\
\stackrel{\infty}{N} \\
\grave{1} \\
\stackrel{1}{0}\end{array}$ & 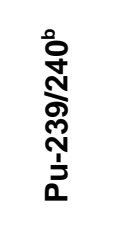 & $\begin{array}{l}\text { :̊ } \\
\frac{1}{1} \\
\text { ம் }\end{array}$ & $\begin{array}{l}\stackrel{\text { N }}{J} \\
\text { J }\end{array}$ & 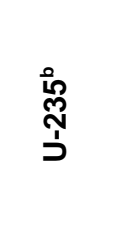 & $\begin{array}{l}\stackrel{0}{\sim} \\
\stackrel{\text { }}{J} \\
\text { J }\end{array}$ & \\
\hline \multicolumn{3}{|c|}{ FALs } & 3,292 & 487.4 & 255.7 & 9,239 & 13,900 & 12,690 & 55,220 & 131,400 & 1,709 & 9,752 & N/A \\
\hline A01 & $371 \mathrm{AX01}$ & $25-30$ & 1.64 & 425 & $2.08(\mathrm{~J})$ & 2.99 & 5.51 & 11.9 & 15.6 & 5.25 & 0.219 & 1.27 & $\mathrm{~N} / \mathrm{A}$ \\
\hline N/A & N/A & Fraction & 0.0005 & 0.87 & 0.0081 & 0.00032 & 0.0004 & 0.00094 & 0.00028 & 0.00004 & 0.00013 & 0.00013 & 0.88 \\
\hline
\end{tabular}

aGamma-emitting radionuclide bIsotope

$\mathrm{N} / \mathrm{A}=$ Not applicable

$\mathrm{J}=$ Estimated value 


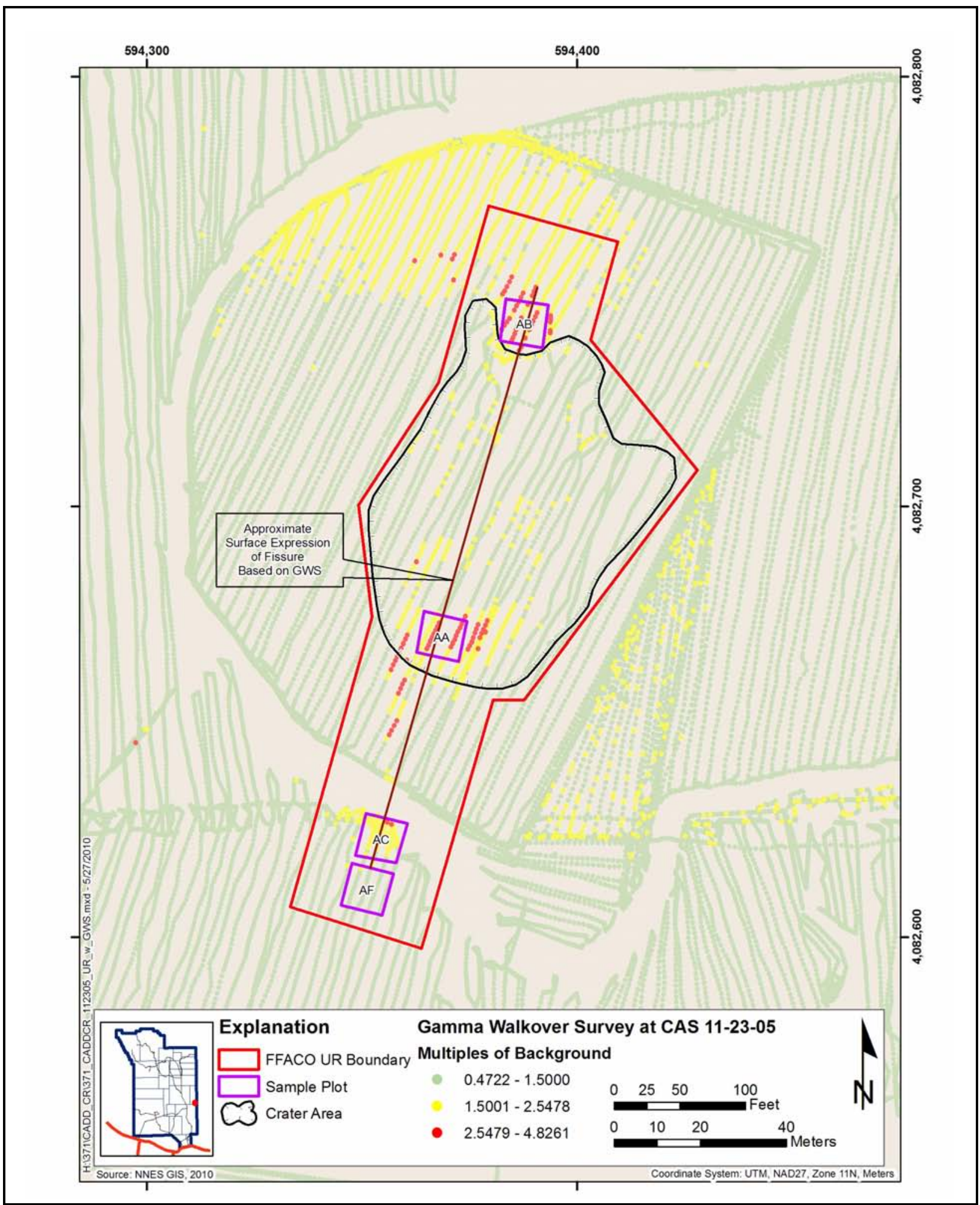

Figure A.3-5

Pin Stripe UR Area 


\section{A.3.4 Revised Conceptual Site Model}

The CAIP requirements (NNSA/NSO, 2009b) were met at this CAS. The information gathered during the CAI supports the CSM as presented in the CAIP for CAU 371. Therefore, no revisions were necessary to the CSM. 


\section{A.4.0 CAS 18-45-01, U-18j-2 Crater (Johnnie Boy)}

Corrective Action Site 18-45-01 is located in the central portion of Area 18 of the NTS, east of Buckboard Mesa, and is in a valley area near Airport Road. The CAS consists of an atmospheric deposition of radioactive material to the soil surface from the U-18j-2 Johnnie Boy crater test. Additional detail is provided in the CAIP (NNSA/NSO, 2009b).

\section{A.4.1 Corrective Action Investigation}

A total of 70 characterization samples (60 primary release samples from 14 plots and 10 other release samples from the ejecta and sedimentation areas) (including 4 FDs) were collected during investigation activities at Johnnie Boy. All samples were analyzed for gamma spectroscopy; Sr-90; and isotopic $\mathrm{U}, \mathrm{Pu}$, and $\mathrm{Am}$. The sample IDs, locations, and types are listed in Table A.4-1. The specific CAI activities conducted to satisfy the CAIP requirements at this CAS (NNSA/NSO, 2009b) are described in the following sections.

Table A.4-1

Samples Collected at Johnnie Boy

(Page 1 of 3)

\begin{tabular}{|c|c|c|c|c|}
\hline $\begin{array}{l}\text { Samplel } \\
\text { Plot } \\
\text { Location }\end{array}$ & $\begin{array}{l}\text { Sample } \\
\text { Number }\end{array}$ & $\begin{array}{l}\text { Depth } \\
\text { (cm bgs) }\end{array}$ & Matrix & Purpose \\
\hline \multirow{5}{*}{ BA } & 371BA01 & $0.0-5.0$ & Soil & Environmental \\
\hline & 371BA02 & $0.0-5.0$ & Soil & FD of \#371BA01 \\
\hline & 371BA03 & $0.0-5.0$ & Soil & Environmental \\
\hline & 371BA04 & $0.0-5.0$ & Soil & Environmental \\
\hline & 371BA05 & $0.0-5.0$ & Soil & Environmental \\
\hline \multirow{4}{*}{ BB } & 371BB01 & $0.0-5.0$ & Soil & Environmental \\
\hline & 371BB02 & $0.0-5.0$ & Soil & Environmental \\
\hline & 371BB03 & $0.0-5.0$ & Soil & Environmental, Full Lab QC \\
\hline & 371BB04 & $0.0-5.0$ & Soil & Environmental \\
\hline \multirow{4}{*}{$B C$} & 371BC01 & $0.0-5.0$ & Soil & Environmental \\
\hline & 371BC02 & $0.0-5.0$ & Soil & Environmental \\
\hline & $371 \mathrm{BC} 03$ & $0.0-5.0$ & Soil & Environmental \\
\hline & 371BC04 & $0.0-5.0$ & Soil & Environmental \\
\hline
\end{tabular}


Table A.4-1

Samples Collected at Johnnie Boy

(Page 2 of 3 )

\begin{tabular}{|c|c|c|c|c|}
\hline $\begin{array}{l}\text { Samplel } \\
\text { Plot } \\
\text { Location }\end{array}$ & $\begin{array}{l}\text { Sample } \\
\text { Number }\end{array}$ & $\begin{array}{c}\text { Depth } \\
\text { (cm bgs) }\end{array}$ & Matrix & Purpose \\
\hline \multirow{4}{*}{ BD } & 371BD01 & $0.0-5.0$ & Soil & Environmental \\
\hline & 371BD02 & $0.0-5.0$ & Soil & Environmental \\
\hline & 371BD03 & $0.0-5.0$ & Soil & Environmental \\
\hline & 371BD04 & $0.0-5.0$ & Soil & Environmental \\
\hline \multirow{4}{*}{$\mathrm{BE}$} & 371BE01 & $0.0-5.0$ & Soil & Environmental \\
\hline & 371BE02 & $0.0-5.0$ & Soil & Environmental \\
\hline & 371BE03 & $0.0-5.0$ & Soil & Environmental \\
\hline & 371BE04 & $0.0-5.0$ & Soil & Environmental \\
\hline \multirow{4}{*}{$\mathrm{BF}$} & 371BF01 & $0.0-5.0$ & Soil & Environmental \\
\hline & 371BF02 & $0.0-5.0$ & Soil & Environmental, Full Lab QC \\
\hline & 371BF03 & $0.0-5.0$ & Soil & Environmental \\
\hline & 371BF04 & $0.0-5.0$ & Soil & Environmental \\
\hline \multirow{4}{*}{ BG } & 371BG01 & $0.0-5.0$ & Soil & Environmental \\
\hline & 371BG02 & $0.0-5.0$ & Soil & Environmental \\
\hline & 371BG03 & $0.0-5.0$ & Soil & Environmental \\
\hline & 371BG04 & $0.0-5.0$ & Soil & Environmental \\
\hline \multirow{5}{*}{$\mathrm{BH}$} & 371BH01 & $0.0-5.0$ & Soil & Environmental \\
\hline & 371BH02 & $0.0-5.0$ & Soil & Environmental \\
\hline & 371BH03 & $0.0-5.0$ & Soil & FD of \#371BH02 \\
\hline & 371BH04 & $0.0-5.0$ & Soil & Environmental \\
\hline & 371BH05 & $0.0-5.0$ & Soil & Environmental \\
\hline \multirow{4}{*}{ BJ } & 371BJ01 & $0.0-5.0$ & Soil & Environmental \\
\hline & 371BJ02 & $0.0-5.0$ & Soil & Environmental \\
\hline & 371BJ03 & $0.0-5.0$ & Soil & Environmental \\
\hline & 371BJ04 & $0.0-5.0$ & Soil & Environmental \\
\hline \multirow{5}{*}{ BK } & 371BK01 & $0.0-5.0$ & Soil & Environmental, Full Lab QC \\
\hline & 371BK02 & $0.0-5.0$ & Soil & Environmental \\
\hline & 371BK03 & $0.0-5.0$ & Soil & Environmental \\
\hline & 371BK04 & $0.0-5.0$ & Soil & FD of \#371BK03 \\
\hline & 371BK05 & $0.0-5.0$ & Soil & Environmental \\
\hline
\end{tabular}


Table A.4-1

Samples Collected at Johnnie Boy

(Page 3 of 3 )

\begin{tabular}{|c|c|c|c|c|}
\hline $\begin{array}{l}\text { Samplel } \\
\text { Plot } \\
\text { Location }\end{array}$ & $\begin{array}{l}\text { Sample } \\
\text { Number }\end{array}$ & $\begin{array}{c}\text { Depth } \\
\text { (cm bgs) }\end{array}$ & Matrix & Purpose \\
\hline \multirow{4}{*}{$\mathrm{BL}$} & 371BL01 & $0.0-5.0$ & Soil & Environmental \\
\hline & 371BL02 & $0.0-5.0$ & Soil & Environmental \\
\hline & 371BL03 & $0.0-5.0$ & Soil & Environmental \\
\hline & 371BL04 & $0.0-5.0$ & Soil & Environmental \\
\hline \multirow{4}{*}{$\mathrm{BM}$} & 371BM01 & $0.0-5.0$ & Soil & Environmental \\
\hline & 371BM02 & $0.0-5.0$ & Soil & Environmental \\
\hline & 371BM03 & $0.0-5.0$ & Soil & Environmental \\
\hline & 371BM04 & $0.0-5.0$ & Soil & Environmental \\
\hline \multirow{5}{*}{$\mathrm{BN}$} & 371BN01 & $0.0-5.0$ & Soil & Environmental \\
\hline & 371BN02 & $0.0-5.0$ & Soil & Environmental \\
\hline & 371BN03 & $0.0-5.0$ & Soil & $\begin{array}{c}\text { Environmental, Full Lab QC }{ }^{a}, \\
\text { FD of } \# 371 B N 02\end{array}$ \\
\hline & 371BN04 & $0.0-5.0$ & Soil & Environmental \\
\hline & 371BN05 & $0.0-5.0$ & Soil & Environmental \\
\hline \multirow{4}{*}{$\mathrm{BP}$} & 371BP01 & $0.0-5.0$ & Soil & Environmental \\
\hline & 371BP02 & $0.0-5.0$ & Soil & Environmental \\
\hline & 371BP03 & $0.0-5.0$ & Soil & Environmental \\
\hline & 371BP04 & $0.0-5.0$ & Soil & Environmental \\
\hline \multirow{2}{*}{ B01 } & 371BX01 & $0.0-5.0$ & Soil & Environmental \\
\hline & $371 \mathrm{~B} \times 02$ & $5.0-10.0$ & Soil & Environmental \\
\hline \multirow{2}{*}{ B02 } & $371 \mathrm{~B} \times 03$ & $0.0-5.0$ & Soil & Environmental \\
\hline & 371BX04 & $5.0-10.0$ & Soil & Environmental \\
\hline \multirow{3}{*}{ B03 } & 371BX05 & $0.0-5.0$ & Soil & Environmental \\
\hline & $371 \mathrm{~B} \times 06$ & $5.0-10.0$ & Soil & Environmental \\
\hline & $371 \mathrm{~B} \times 10$ & $25.0-30.0$ & Soil & Environmental \\
\hline \multirow{3}{*}{ B04 } & 371BX11 & $0.0-5.0$ & Soil & Environmental \\
\hline & $371 B \times 12$ & $5.0-10.0$ & Soil & Environmental \\
\hline & $371 \mathrm{~B} \times 13$ & $25.0-30.0$ & Soil & Environmental \\
\hline
\end{tabular}

aFull Lab QC for Sr-90 was run on Sample 371BN02, not 371BN03. 


\section{A.4.1.1 Visual Inspections}

Visual inspections of Johnnie Boy were conducted over the course of the field investigation and included site walks, sampling efforts, and radiological surveys. The following test-related debris and equipment were identified: two corrugated metal cellars with concrete lids, several metal sampling-related structures housed in concrete slabs, several concrete slabs covered with metal plates, two metal frames and wooden platforms, one feature with a steel lid housed in a concrete apron, one large circular pit, and five smaller circular pits. No chemical biasing factors (e.g., stains or odors) were noted on or adjacent to any of the objects. The debris and equipment were screened for radioactivity and swipe samples were taken where applicable. No radiological biasing factors (e.g., elevated readings or removable contamination) were identified on any of the objects. Therefore, no samples of the testing-related debris were collected. The locations of these physical features are shown on Figure A.4-1.

In addition to the notable physical features, drainages are present flowing through and downgradient of the site, and were identified as potential routes for migration of contaminated sediments. The major drainage exiting the Johnnie Boy site was visually inspected, and biased samples of the two closest sedimentation areas downgradient of GZ were collected. No additional biasing factors were noted at the CAS based on visual inspections. Figure A.4-2 shows the sedimentation sample locations.

\section{A.4.1.2 Radiological Surveys}

Ground-based radiological surveys were conducted at Johnnie Boy early in the CAI. These surveys were performed to examine the distribution of radiological contamination across the site, which was used as input into the location and placement of the soil sampling plots.

Measurements for external dose were obtained over a rough 50-m grid spacing using a Bicron microrem-per-hour handheld meter. Readings were collected at a height of about $1 \mathrm{~m}$ above the ground surface. There were 168 locations surveyed, divided over two distinct areas at the Johnnie Boy site. This survey did not produce results that were useful in defining sample locations or patterns of radiological distribution. 


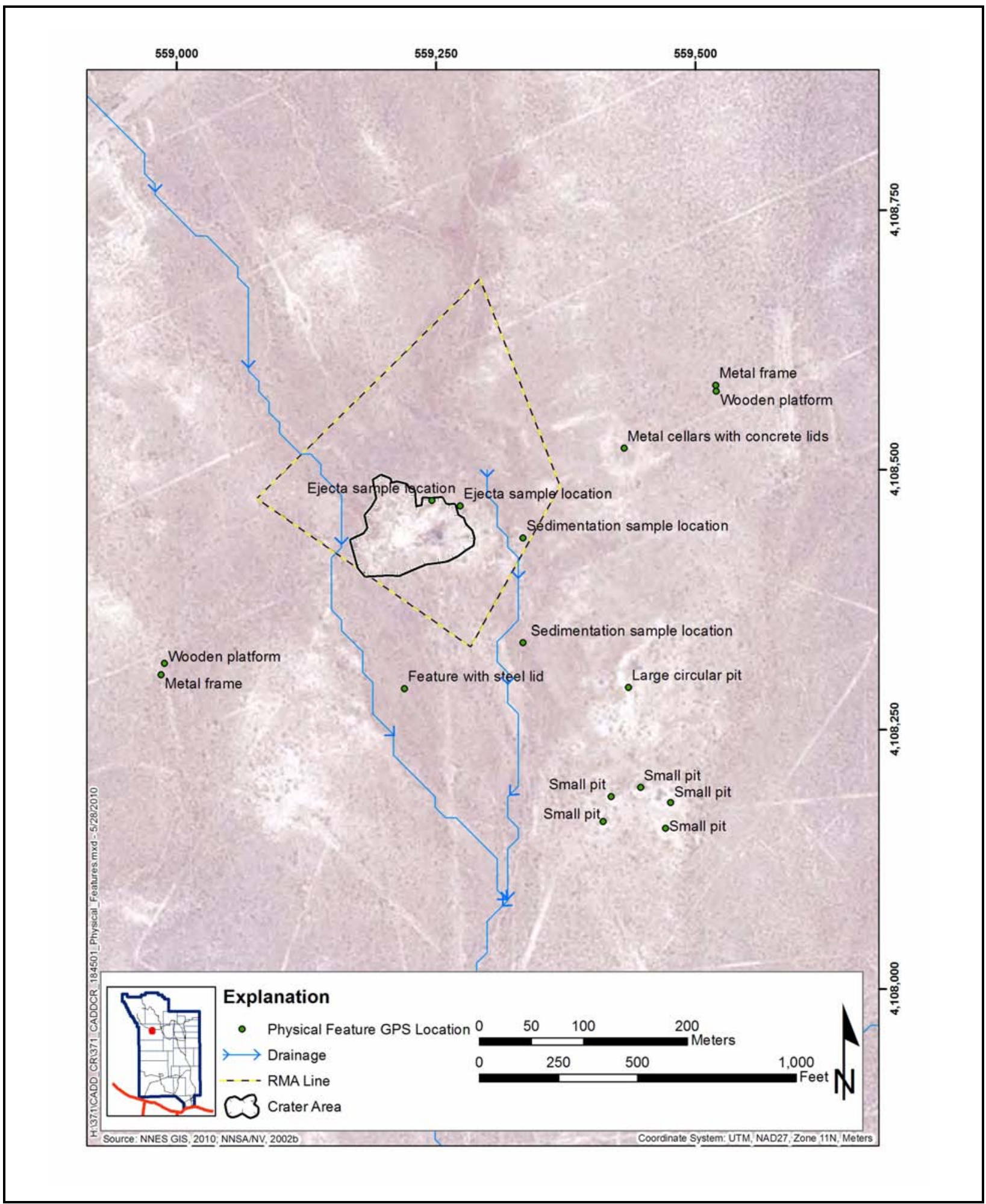

Figure A.4-1

Features Identified during Visual Inspection of Johnnie Boy 


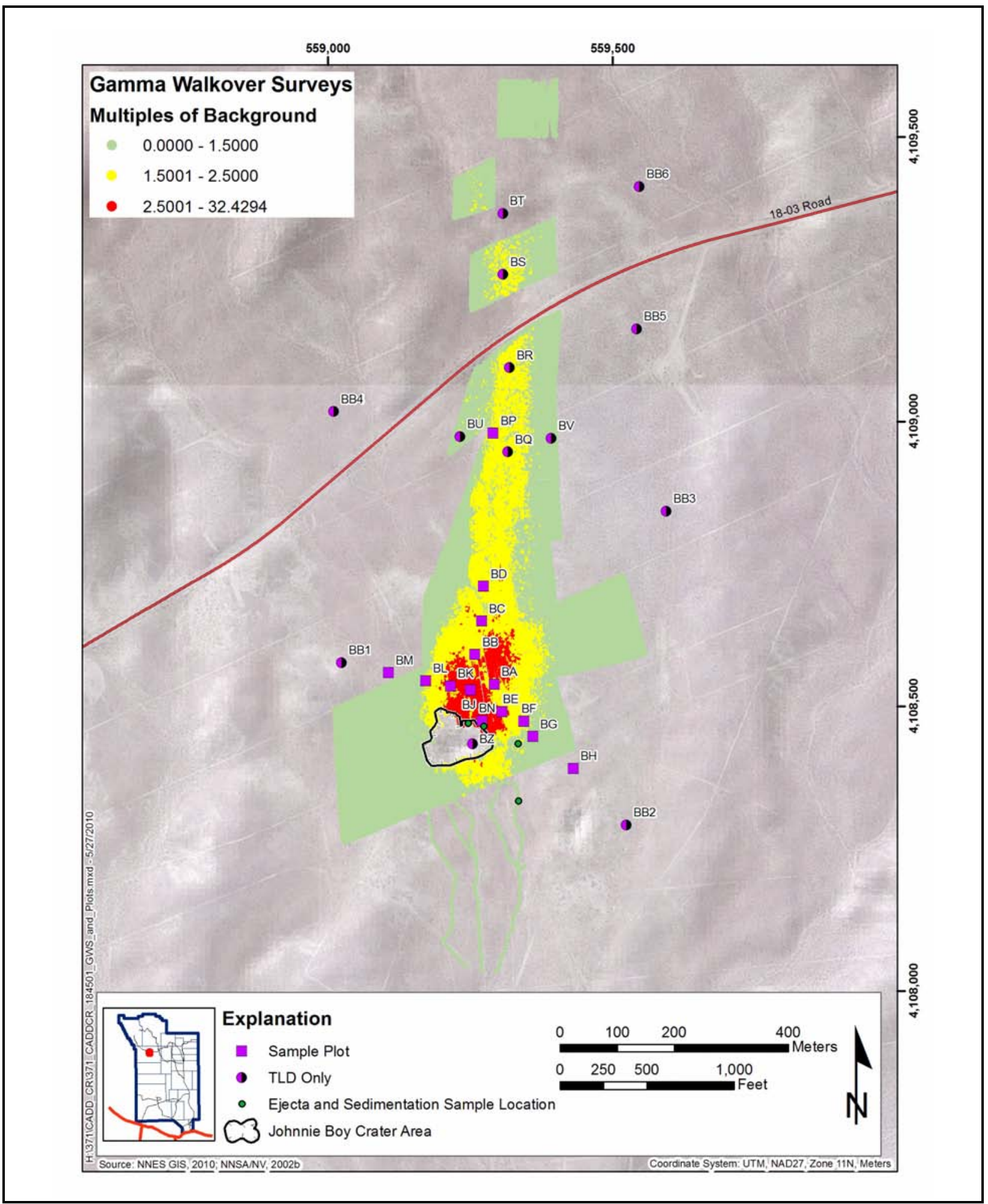

Figure A.4-2

Gamma Walkover Surveys of Selected Locations at Johnnie Boy 
Global Positioning System-assisted GWSs were conducted over of the majority of Johnnie Boy to verify the location of the plume as depicted in the 1994 aerial radiological survey $(\mathrm{BN}, 1999)$ and to inspect several small ephemeral streams for evidence of contaminant migration (readings above background were not detected within the drainages). Count-rate data were collected with a TSA Systems PRM-470 model plastic scintillator. Data were logged, and position data were collected at 1-second intervals, via a Trimble Systems GeoXT GPS unit. The walkover speed was approximately 1 to 2 meters per second with the radiation detector held at a height of about $18 \mathrm{in}$. above the ground surface. Data were post-processed, loaded into a geographical information system, color-coded, and displayed on a map of Johnnie Boy. Figure A.4-2 provides the results of the GWS survey.

The results of the GWS were used in the determination of the locations of the soil sample plots at the Johnnie Boy site. Three vectors were established at the site, each beginning with an inner plot placed within the general areas having the highest anomalous radiological readings as determined from the GWS. Additionally, elevated readings were detected within the ejecta at Johnnie Boy. Biased samples were collected at the two areas of highest radiological readings within the ejecta. Figure A.4-2 shows the ejecta sample locations.

\section{A.4.1.3 TLD Measurements}

The TLDs listed in Table A.4-2 were used at the Johnnie Boy site to measure external doses. Figure A.4-3 shows TLD locations. The TLDs at locations BB1 through BB6 were installed at "field” background locations. The TLD at location BZ was placed inside the crater at GZ. Sampling plots were placed at TLD locations BA through BP.

A TLD that was placed at location BP for a short duration exposure time of 45 days resulted in an anomalous value that was inconsistent with other readings at the site that had the full 94 days of exposure time. To address this anomaly, another TLD was placed at the same location and exposed for the full exposure period. The result from this replacement TLD was consistent with other results and was used in calculating TED at that location.

All TLDs were included in the routine quarterly read of the NTS environmental monitoring TLDs. Details of the environmental monitoring TLD program and TLD QC are presented in Section A.6.0. The TLD results are discussed in Section A.4.2.1. 
Table A.4-2

TLDs at Johnnie Boy

\begin{tabular}{|c|c|c|c|c|}
\hline Location & TLD No. & Date Placed & $\begin{array}{c}\text { Date } \\
\text { Removed }\end{array}$ & Purpose \\
\hline$\overline{B A}$ & 4638 & $03 / 25 / 2009$ & $06 / 29 / 2009$ & Sample plot \\
\hline BB & 4606 & 03/25/2009 & 06/29/2009 & Sample plot \\
\hline BC & 4373 & $03 / 25 / 2009$ & $06 / 29 / 2009$ & Sample plot \\
\hline$B D$ & 4405 & $03 / 25 / 2009$ & 06/29/2009 & Sample plot \\
\hline $\mathrm{BE}$ & 4557 & $03 / 25 / 2009$ & 06/29/2009 & Sample plot \\
\hline $\mathrm{BF}$ & 4406 & 03/25/2009 & $06 / 29 / 2009$ & Sample plot \\
\hline$B G$ & 5082 & 03/25/2009 & 06/29/2009 & Sample plot \\
\hline $\mathrm{BH}$ & 4513 & 03/25/2009 & $06 / 29 / 2009$ & Sample plot \\
\hline BJ & 4871 & 03/25/2009 & 06/29/2009 & Sample plot \\
\hline BK & 4313 & $03 / 25 / 2009$ & $06 / 29 / 2009$ & Sample plot \\
\hline $\mathrm{BL}$ & 4500 & $03 / 25 / 2009$ & $06 / 29 / 2009$ & Sample plot \\
\hline BM & 4445 & $03 / 25 / 2009$ & $06 / 29 / 2009$ & Sample plot \\
\hline $\mathrm{BN}$ & 4707 & $11 / 13 / 2009$ & $02 / 16 / 2010$ & Sample plot \\
\hline $\mathrm{BP}$ & 4468 & $11 / 13 / 2009$ & 02/16/2010 & Sample plot \\
\hline $\mathrm{BQ}$ & 5121 & $11 / 13 / 2009$ & 02/16/2010 & TLD only \\
\hline $\mathrm{BR}$ & 4385 & $11 / 13 / 2009$ & $02 / 16 / 2010$ & TLD only \\
\hline BS & 5186 & $11 / 13 / 2009$ & $02 / 16 / 2010$ & TLD only \\
\hline BT & 4875 & $11 / 13 / 2009$ & 02/16/2010 & TLD only \\
\hline $\mathrm{BU}$ & 4755 & $11 / 13 / 2009$ & $02 / 16 / 2010$ & TLD only \\
\hline $\mathrm{BV}$ & 4512 & $11 / 13 / 2009$ & 02/16/2010 & TLD only \\
\hline BZ & 4597 & 03/25/2009 & 06/29/2009 & Inside crater \\
\hline BB1 & 4451 & $03 / 25 / 2009$ & $06 / 29 / 2009$ & Background TLD location \\
\hline BB2 & 4923 & $03 / 25 / 2009$ & $06 / 29 / 2009$ & Background TLD location \\
\hline BB3 & 4315 & 03/25/2009 & $06 / 29 / 2009$ & Background TLD location \\
\hline BB4 & 4906 & $11 / 13 / 2009$ & $02 / 16 / 2010$ & Background TLD location \\
\hline BB5 & 4302 & $11 / 13 / 2009$ & $02 / 16 / 2010$ & Background TLD location \\
\hline BB6 & 4669 & $11 / 13 / 2009$ & 02/16/2010 & Background TLD location \\
\hline
\end{tabular}




\section{A.4.1.4 Sample Collection}

For the primary release at Johnnie Boy, sampling activities for the determination of internal dose at sample plots consisted of the collection of 60 primary release composite surface soil samples (including 4 duplicates) from 14 sample plots within Johnnie Boy. Sample plots along each of three sampling vectors originating from the general areas of the highest GWS values (northeast of GZ) and extending outward in (generally) the north, southeast, and west directions. Four sample plots (BB, BC, BD, BP) were established along the north vector; four sample plots (BJ, BK, BL, BM) were established along the west vector; and five sample plots (BA, BE, BF, BG, BH) were established along the southeast vector. One additional sample plot (BN) was established northeast of the crater within an area of elevated GWS readings. Plot sample locations are shown on Figure A.4-3.

For the other releases at Johnnie Boy, two samples (0 to 5 and 5 to $10 \mathrm{~cm}$ bgs) were collected from each of two sedimentation areas (locations B01 and B02) within the major wash (downgradient of the crater area) to determine whether migration away from the test area has occurred. Three samples ( 0 to 5,5 to 10, and 25 to $30 \mathrm{~cm}$ bgs) were also taken from each of two areas of elevated radiological readings, adjacent to the northeast side of the crater, within the ejecta (locations B03 and B04). These ejecta samples were collected to determine whether buried contamination exists. Biased sample locations are shown on Figure A.4-3.

\section{A.4.1.5 Field Screening}

All soil samples were field screened after collection, but before placement into the 1-gallon metal cans or amber glass jars. The field screening was used to evaluate the alpha and beta/gamma contamination levels on the surface of the soil and to compare the values to a sample of soil collected from a background location. The FSRs were used for selection of the vertical samples collected from the ejecta. For these samples (three each at each location) the uppermost interval (i.e., 0 to $5 \mathrm{~cm}$ depth) and lowermost interval (25 to $30 \mathrm{~cm}$ bgs) of each ejecta sample were submitted to the laboratory for analyses, and the FSRs were used to determine which sample in between the uppermost and lowermost interval was submitted for analyses. For both ejecta sample locations (B03 and B04), the samples collected between 5 and $10 \mathrm{~cm}$ depth exhibited the highest field-screening values for both alpha and beta. Therefore, those samples were submitted to the laboratory for analysis. These field-screening data were recorded on SCLs, which are retained in the project files. 


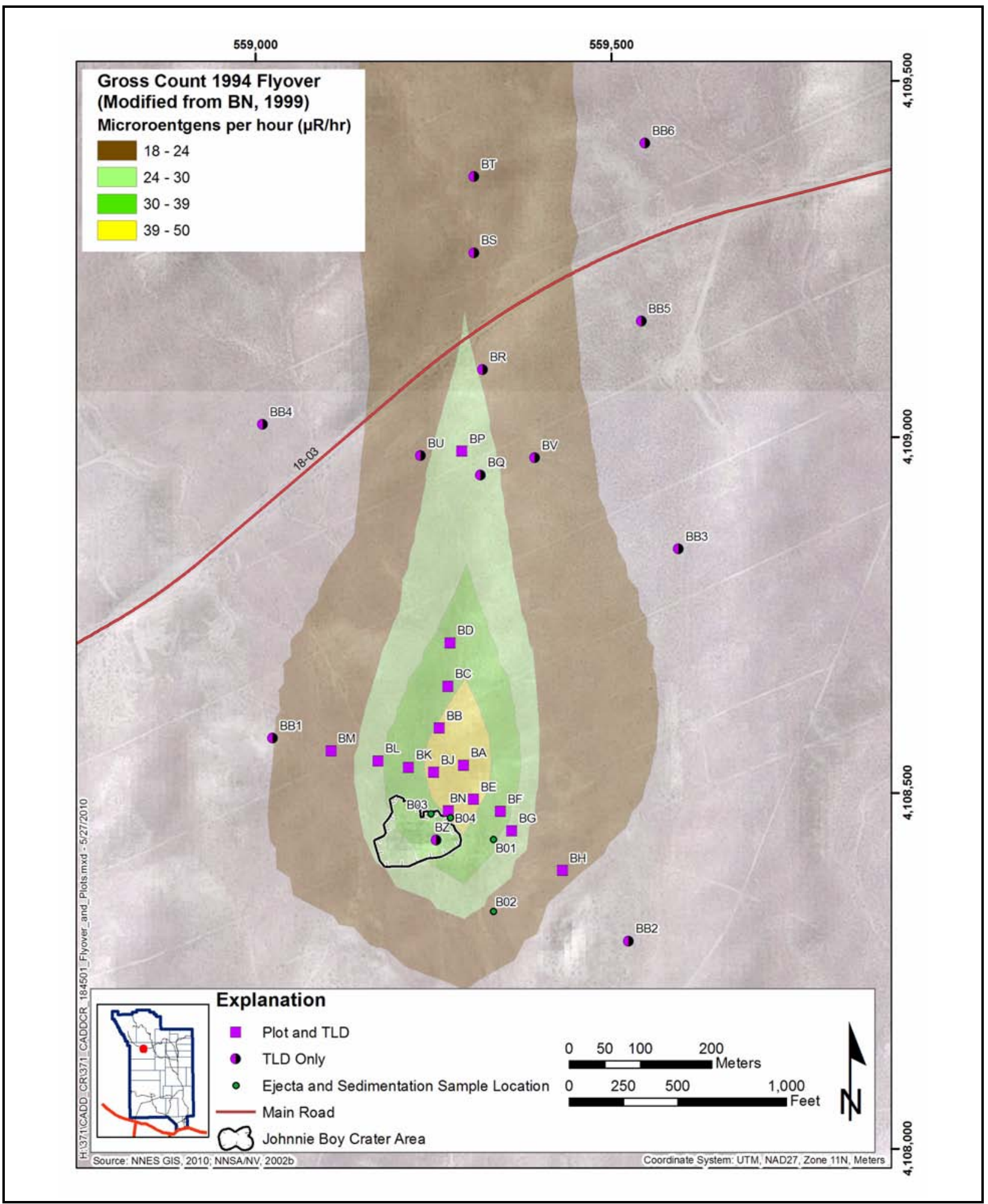

Figure A.4-3

Johnnie Boy Sample and TLD Locations 


\section{A.4.1.6 Deviations}

No deviations to the CAU 371 CAIP (NNSA/NSO, 2009b) were noted.

\section{A.4.2 Investigation Results}

The following sections provide analytical and computational results for samples collected for investigation of the primary and other releases at Johnnie Boy as outlined in the CAIP (NNSA/NSO, 2009b). Samples were analyzed according to the CAIP-specified analytical methods, which included analysis for gamma spectroscopy; Sr-90; and isotopic U, Pu, and Am. The analytical parameters and laboratory methods used during this investigation were discussed in Section A.2.0 and are listed in Table A.2-1.

The process used for establishing the FALs is presented in Appendix C. As presented in Section A.2.5, the Remote Work Area exposure scenario with an exposure duration of $8 \mathrm{hr} /$ day, 42 day/yr, for 25 years was the basis for the FALs.

The internal dose calculated from soil sample results, and the external dose calculated from TLD measurements were combined to determine TED at each primary release sample location. Results from the TLD locations are summarized in Section A.4.2.1. Results of internal dose calculated from analytical results of composite soil samples collected from each sample plot are summarized in Section A.4.2.2. The combined estimated radiological dose for each sample plot, expressed as the TED, is summarized in Section A.4.2.3. Radiological results for the other release (i.e., ejecta and sedimentation samples) are summarized in Section A.4.2.4.

The primary release results are reported as doses that are comparable to the dose-based FAL as established in Appendix C. For the other releases, the results are reported as individual radionuclide concentrations that are comparable to the individual radionuclide FALs as established in Appendix C. Results that are equal to or greater than FALs are identified by bold text in the results tables. 


\section{A.4.2.1 External Radiological Dose Measurements}

Estimates of the external dose that a receptor would receive at each sample plot were derived from the results of TLDs staged at the Johnnie Boy sample plots. The values for the individual elements in each TLD and the average TLD values for Johnnie Boy are presented in Table A.4-3. For convenience, the dose values listed are based on an exposure duration equivalent to a full-time worker being present at the site (i.e., the Industrial Area exposure duration of 2,250 hr/yr). These dose values were converted to other exposure scenarios by scaling the number to the appropriate exposure duration in hours per year. The 95 percent UCL of external dose for each exposure scenario is presented in Table A.4-4.

Table A.4-3

External Dose Measurements at Johnnie Boy (mrem/IA-yr)

\begin{tabular}{|c|c|c|c|c|c|}
\hline Location & Element 2 & Element 3 & Element 4 & $\begin{array}{c}\text { Average TLD } \\
\text { Value }\end{array}$ & $\begin{array}{c}\text { 95\% UCL of } \\
\text { TLD }\end{array}$ \\
\hline$\overline{B A}$ & 48.0 & 42.0 & 43.0 & 444.3 & 499.8 \\
\hline BB & 35.4 & 29.4 & 26.9 & 30.6 & 38.0 \\
\hline$B C$ & 35.9 & 33.0 & 30.4 & 33.1 & 37.7 \\
\hline $\mathrm{BD}$ & 27.0 & 21.6 & 20.7 & 23.1 & 28.9 \\
\hline $\mathrm{BE}$ & 59.0 & 47.6 & 45.6 & 50.7 & 62.9 \\
\hline $\mathrm{BF}$ & 21.5 & 17.0 & 15.4 & 17.9 & 23.2 \\
\hline BG & 13.7 & 9.4 & 7.2 & 10.1 & 15.6 \\
\hline $\mathrm{BH}$ & 2.1 & 1.6 & $0^{a}$ & 1.2 & 3.2 \\
\hline BJ & 61.0 & 55.1 & 54.3 & 56.8 & 63.0 \\
\hline $\mathrm{BK}$ & 41.4 & 35.4 & 30.3 & 35.7 & 45.0 \\
\hline $\mathrm{BL}$ & 14.0 & 11.8 & 11.0 & 12.3 & 14.9 \\
\hline $\mathrm{BM}$ & 4.3 & 1.5 & 0.5 & 2.1 & 5.4 \\
\hline $\mathrm{BN}$ & 63.1 & 50.7 & 52.3 & 55.4 & 66.7 \\
\hline $\mathrm{BP}$ & 17.1 & 12.1 & 13.5 & 14.2 & 18.6 \\
\hline $\mathrm{BQ}$ & 18.2 & 15.7 & 11.7 & 15.2 & 20.7 \\
\hline BR & 17.3 & 14.0 & 11.8 & 14.4 & 19.1 \\
\hline BS & 16.5 & 14.8 & 12.0 & 14.4 & 18.3 \\
\hline BT & 5.9 & 3.8 & 2.2 & 4.0 & 7.1 \\
\hline $\mathrm{BU}$ & 7.6 & 3.4 & 1.8 & 4.3 & 9.3 \\
\hline $\mathrm{BV}$ & 0.7 & $0^{a}$ & $0^{a}$ & $0^{a}$ & 5.3 \\
\hline$B Z$ & 16.9 & 13.0 & 11.3 & 13.7 & 18.5 \\
\hline
\end{tabular}

aWere the reading was less than zero, a value of zero was used.

Bold indicates the values exceeding $25 \mathrm{mrem} / \mathrm{yr}$. 
Table A.4-4

Johnnie Boy 95\% UCL External Dose for Each Exposure Scenario

\begin{tabular}{|c|c|c|c|}
\hline Plot or Location & $\begin{array}{l}\text { Industrial Area } \\
\text { (mrem/IA-yr) }\end{array}$ & $\begin{array}{l}\text { Remote Work Area } \\
\text { (mrem/RW-yr) }\end{array}$ & $\begin{array}{c}\text { Occasional Use Area } \\
\text { (mrem/OU-yr) }\end{array}$ \\
\hline$\overline{B A}$ & $\overline{49.8}$ & $\overline{7.4}$ & $\overline{1.8}$ \\
\hline BB & 38.0 & 5.7 & 1.3 \\
\hline$B C$ & 37.7 & 5.6 & 1.3 \\
\hline $\mathrm{BD}$ & 28.9 & 4.3 & 1.0 \\
\hline $\mathrm{BE}$ & 62.9 & 9.4 & 2.2 \\
\hline $\mathrm{BF}$ & 23.2 & 3.5 & 0.8 \\
\hline BG & 15.6 & 2.3 & 0.6 \\
\hline $\mathrm{BH}$ & 3.2 & 0.5 & 0.1 \\
\hline BJ & 63.0 & 9.4 & 2.2 \\
\hline BK & 45.0 & 6.7 & 1.6 \\
\hline $\mathrm{BL}$ & 14.9 & 2.2 & 0.5 \\
\hline $\mathrm{BM}$ & 5.4 & 0.8 & 0.2 \\
\hline $\mathrm{BN}$ & 66.7 & 10.0 & 2.4 \\
\hline $\mathrm{BP}$ & 18.6 & 2.8 & 0.7 \\
\hline $\mathrm{BQ}$ & 20.7 & 3.1 & 0.7 \\
\hline $\mathrm{BR}$ & 19.1 & 2.8 & 0.7 \\
\hline BS & 18.3 & 2.7 & 0.7 \\
\hline BT & 7.1 & 1.1 & 0.3 \\
\hline $\mathrm{BU}$ & 9.3 & 1.4 & 0.3 \\
\hline BV & 5.3 & 0.8 & 0.2 \\
\hline $\mathrm{BZ}$ & 18.5 & 2.8 & 0.7 \\
\hline
\end{tabular}

Bold indicates the values exceeding $25 \mathrm{mrem} / \mathrm{yr}$.

\section{A.4.2.2 Internal Radiological Dose Estimations}

Estimates for the internal dose that a receptor would receive at each sample plot at Johnnie Boy were determined through the evaluation of the soil sample analytical results and the RESRAD computer code (Yu et al., 2001) (see Appendix C, Attachment C-1). Results are presented in Table A.4-5. As shown in Table A.4-6, the contribution to TED from internal dose is not significant. For the location of the maximum internal dose (plot BC), internal dose was 0.13 percent of the Remote Work Area TED. Data tables listing the analytical results for individual radionuclides in each composite sample are presented in Appendix F. The 95 percent UCL of internal dose for each exposure scenario is presented in Table A.4-7. 
Table A.4-5

Internal Dose Estimations at Johnnie Boy Sample Plots (mrem/IA-yr)

\begin{tabular}{|c|c|c|c|c|c|c|c||}
\hline Plot & Sample 1 & Sample 2 & Sample 3 & Sample 4 & Sample 5 & $\begin{array}{c}\text { Average for } \\
\text { Sample Plot }\end{array}$ & $\begin{array}{c}\text { 95\% UCL for } \\
\text { Sample Plot }\end{array}$ \\
\hline \hline BA & 0.02 & 0.02 & 0.02 & 0.02 & 0.02 & 0.02 & 0.024 \\
\hline BB & 0.02 & 0.02 & 0.02 & 0.02 & -- & 0.02 & 0.024 \\
\hline BC & 0.08 & 0.02 & 0.02 & 0.02 & -- & $\mathbf{0 . 0 4}$ & $\mathbf{0 . 0 6 8}$ \\
\hline BD & 0.02 & 0.02 & 0.02 & 0.02 & -- & 0.02 & 0.025 \\
\hline BE & 0.03 & 0.02 & 0.02 & 0.02 & -- & 0.02 & 0.027 \\
\hline BF & 0.02 & 0.02 & 0.02 & 0.02 & -- & 0.02 & 0.022 \\
\hline BG & 0.02 & 0.02 & 0.02 & 0.02 & -- & 0.02 & 0.025 \\
\hline BH & 0.02 & 0.02 & 0.02 & 0.02 & 0.02 & 0.02 & 0.023 \\
\hline BJ & 0.03 & 0.02 & 0.02 & 0.03 & -- & 0.03 & 0.026 \\
\hline BK & 0.03 & 0.02 & 0.03 & 0.02 & 0.05 & 0.03 & 0.038 \\
\hline BL & 0.02 & 0.02 & 0.02 & 0.02 & -- & 0.02 & 0.025 \\
\hline BM & 0.03 & 0.02 & 0.03 & 0.02 & -- & 0.02 & 0.026 \\
\hline BN & 0.03 & 0.02 & 0.02 & 0.03 & 0.03 & 0.03 & 0.028 \\
\hline BP & 0.03 & 0.03 & 0.02 & 0.02 & -- & 0.03 & 0.026 \\
\hline
\end{tabular}

-- = Duplicate not taken for this plot.

Maximum internal dose value bolded.

Table A.4-6

Johnnie Boy Ratio of Average Internal Dose to External Dose at Each Plot (mrem/RW-yr)

(Page 1 of 2)

\begin{tabular}{|c|c|c|c|c|}
\hline Plot & $\begin{array}{c}\text { Average } \\
\text { Internal Dose }\end{array}$ & $\begin{array}{c}\text { Average } \\
\text { External Dose }\end{array}$ & Average TED & \% TED \\
\hline \hline BA & 0.0039 & 6.62 & 6.63 & 0.06 \\
\hline BB & 0.004 & 4.57 & 4.57 & 0.09 \\
\hline BC & 0.0064 & 4.95 & 4.95 & 0.13 \\
\hline BD & 0.0039 & 3.45 & 3.45 & 0.11 \\
\hline BE & 0.0042 & 7.58 & 7.58 & 0.14 \\
\hline BF & 0.0037 & 2.68 & 1.51 & 0.27 \\
\hline BG & 0.0041 & 1.50 & 0.19 & 2.11 \\
\hline BH & 0.0038 & 0.18 & 8.49 & 0.05 \\
\hline BJ & 0.0043 & 8.48 & 5.34 & 0.09 \\
\hline BK & 0.005 & 5.33 & 1.84 & 0.22 \\
\hline BL & 0.0041 & 1.83 & 0.32 & 1.35 \\
\hline BM & 0.0042 & 0.31 & & \\
\hline
\end{tabular}


Table A.4-6

Johnnie Boy Ratio of Average Internal Dose to External Dose at Each Plot (mrem/RW-yr)

(Page 2 of 2)

\begin{tabular}{|c|c|c|c|c|}
\hline Plot & $\begin{array}{c}\text { Average } \\
\text { Internal Dose }\end{array}$ & $\begin{array}{c}\text { Average } \\
\text { External Dose }\end{array}$ & Average TED & \% TED \\
\hline \hline $\mathrm{BN}$ & 0.0042 & 8.27 & 8.28 & 0.05 \\
\hline $\mathrm{BP}$ & 0.0043 & 2.13 & 2.13 & 0.20 \\
\hline
\end{tabular}

Table A.4-7

Johnnie Boy 95\% UCL Internal Dose for Each Exposure Scenario

\begin{tabular}{|c|c|c|c||}
\hline Plot or Location & $\begin{array}{c}\text { Industrial Area } \\
\text { (mrem/IA-yr) }\end{array}$ & $\begin{array}{c}\text { Remote Work Area } \\
\text { (mrem/RW-yr) }\end{array}$ & $\begin{array}{c}\text { Occasional Use Area } \\
\text { (mrem/OU-yr) }\end{array}$ \\
\hline \hline BA & 0.024 & 0.004 & 0.001 \\
\hline BB & 0.024 & 0.004 & 0.001 \\
\hline BC & 0.068 & 0.012 & 0.004 \\
\hline BD & 0.025 & 0.004 & 0.001 \\
\hline BE & 0.027 & 0.005 & 0.002 \\
\hline BF & 0.022 & 0.004 & 0.001 \\
\hline BG & 0.025 & 0.004 & 0.001 \\
\hline BH & 0.023 & 0.004 & 0.001 \\
\hline BJ & 0.026 & 0.004 & 0.002 \\
\hline BK & 0.038 & 0.007 & 0.002 \\
\hline BL & 0.025 & 0.004 & 0.001 \\
\hline BM & 0.026 & 0.004 & 0.002 \\
\hline BN & 0.028 & 0.004 & 0.002 \\
\hline BP & 0.026 & 0.004 & 0.002 \\
\hline
\end{tabular}

\section{A.4.2.3 Total Effective Dose}

The average TED for each sample (or TLD location) was conservatively calculated by summation of the external dose (TLD) measurement at each plot or location and the highest internal dose estimate from plot BC (Figure A.4-4). The contribution of internal dose to the TED was not a significant percent of the TED (Table A.4-6). Therefore, the maximum internal dose estimate (from plot BC) was conservatively used for the calculation of all TED values. Values for both the average TED and the 95 percent UCL of the TED for the Industrial Area, Remote Work Area, and Occasional Use Area exposure scenarios were determined and are presented in Table A.4-8. 


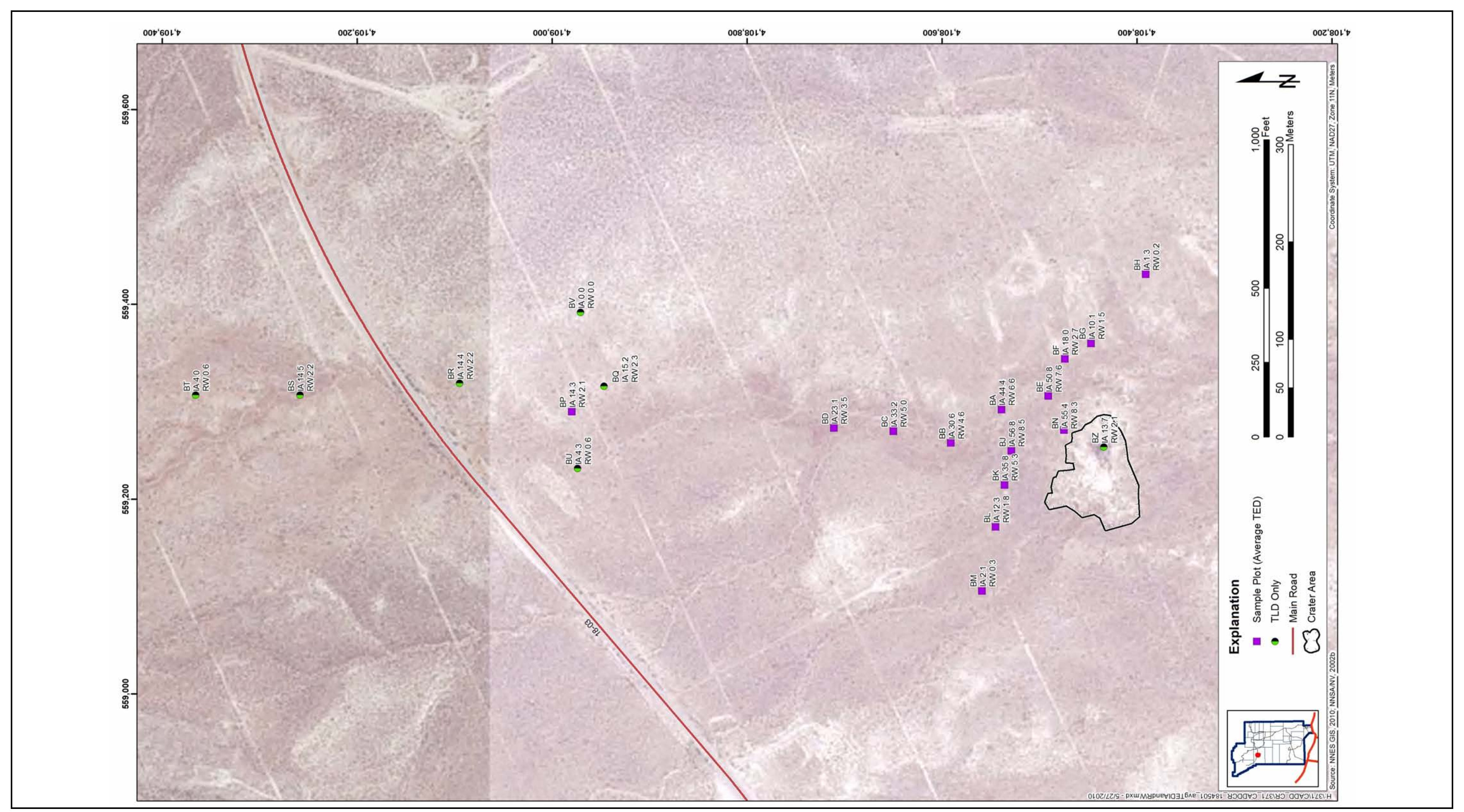

Average TED at Johnnie Boy 
Table A.4-8

Johnnie Boy TED at Sample Locations (mrem/yr)

\begin{tabular}{|c|c|c|c|c|c|c|}
\hline \multirow{2}{*}{$\begin{array}{l}\text { Plot or } \\
\text { Location }\end{array}$} & \multicolumn{2}{|c|}{ Industrial Access } & \multicolumn{2}{|c|}{ Remote Worker } & \multicolumn{2}{|c|}{ Occasional Use } \\
\hline & $\begin{array}{c}\text { Average } \\
\text { TED }\end{array}$ & $\begin{array}{c}\text { 95\% UCL of } \\
\text { TED }\end{array}$ & $\begin{array}{c}\text { Average } \\
\text { TED }\end{array}$ & $\begin{array}{c}\text { 95\% UCL of } \\
\text { TED }\end{array}$ & $\begin{array}{c}\text { Average } \\
\text { TED }\end{array}$ & $\begin{array}{c}95 \% \text { UCL of } \\
\text { TED }\end{array}$ \\
\hline $\mathrm{BA}$ & 44.4 & 49.9 & 6.6 & 7.4 & 1.6 & 1.8 \\
\hline BB & 30.6 & 38.0 & 4.6 & 5.7 & 1.1 & 1.4 \\
\hline $\mathrm{BC}$ & 33.2 & 37.8 & 5.0 & 5.6 & 1.2 & 1.3 \\
\hline $\mathrm{BD}$ & 23.1 & 29.0 & 3.5 & 4.3 & 0.8 & 1.0 \\
\hline $\mathrm{BE}$ & 50.8 & 62.9 & 7.6 & 9.4 & 1.8 & 2.2 \\
\hline $\mathrm{BF}$ & 18.0 & 23.3 & 2.7 & 3.5 & 0.6 & 0.8 \\
\hline BG & 10.1 & 15.7 & 1.5 & 2.3 & 0.4 & 0.6 \\
\hline $\mathrm{BH}$ & 1.3 & 3.3 & 0.2 & 0.5 & 0.05 & 0.1 \\
\hline BJ & 56.8 & 63.1 & 8.5 & 9.4 & 2.0 & 2.2 \\
\hline $\mathrm{BK}$ & 35.8 & 45.1 & 5.3 & 6.7 & 1.3 & 1.6 \\
\hline $\mathrm{BL}$ & 12.3 & 15.0 & 1.8 & 2.2 & 0.4 & 0.5 \\
\hline $\mathrm{BM}$ & 2.1 & 5.5 & 0.3 & 0.8 & 0.1 & 0.2 \\
\hline $\mathrm{BN}$ & 55.4 & 66.8 & 8.3 & 10.0 & 2.0 & 2.4 \\
\hline $\mathrm{BP}$ & 14.3 & 18.7 & 2.1 & 2.8 & 0.5 & 0.7 \\
\hline $\mathrm{BQ}$ & 15.2 & 20.8 & 2.3 & 3.1 & 0.5 & 0.7 \\
\hline $\mathrm{BR}$ & 14.4 & 19.1 & 2.2 & 2.9 & 0.5 & 0.7 \\
\hline BS & 14.5 & 18.4 & 2.2 & 2.7 & 0.5 & 0.7 \\
\hline BT & 4.0 & 7.1 & 0.6 & 1.1 & 0.14 & 0.3 \\
\hline $\mathrm{BU}$ & 4.3 & 9.3 & 0.6 & 1.4 & 0.15 & 0.3 \\
\hline BV & 0.04 & 5.4 & 0.006 & 0.8 & 0.002 & 0.19 \\
\hline$B Z$ & 13.7 & 18.6 & 2.1 & 2.8 & 0.5 & 0.7 \\
\hline
\end{tabular}

Bold indicates the values exceeding $25 \mathrm{mrem} / \mathrm{yr}$.

The results for the sample plots at Johnnie Boy did not exceed the FAL (i.e., the 95 percent UCL of the TED exceeding 25 mrem/RW-yr) at the CAS (Figure A.4-5).

\section{A.4.2.4 Results for Other Release at Johnnie Boy}

Analytical results from the two samples (0 to 5 and 5 to $10 \mathrm{~cm}$ bgs) collected from each of two sedimentation areas within the major wash at Johnnie Boy and the three samples ( 0 to 5, 5 to 10 , and 25 to $30 \mathrm{~cm}$ bgs) taken from each of two areas of elevated radiological readings in the ejecta exceeding the MDCs are presented in the following sections. 


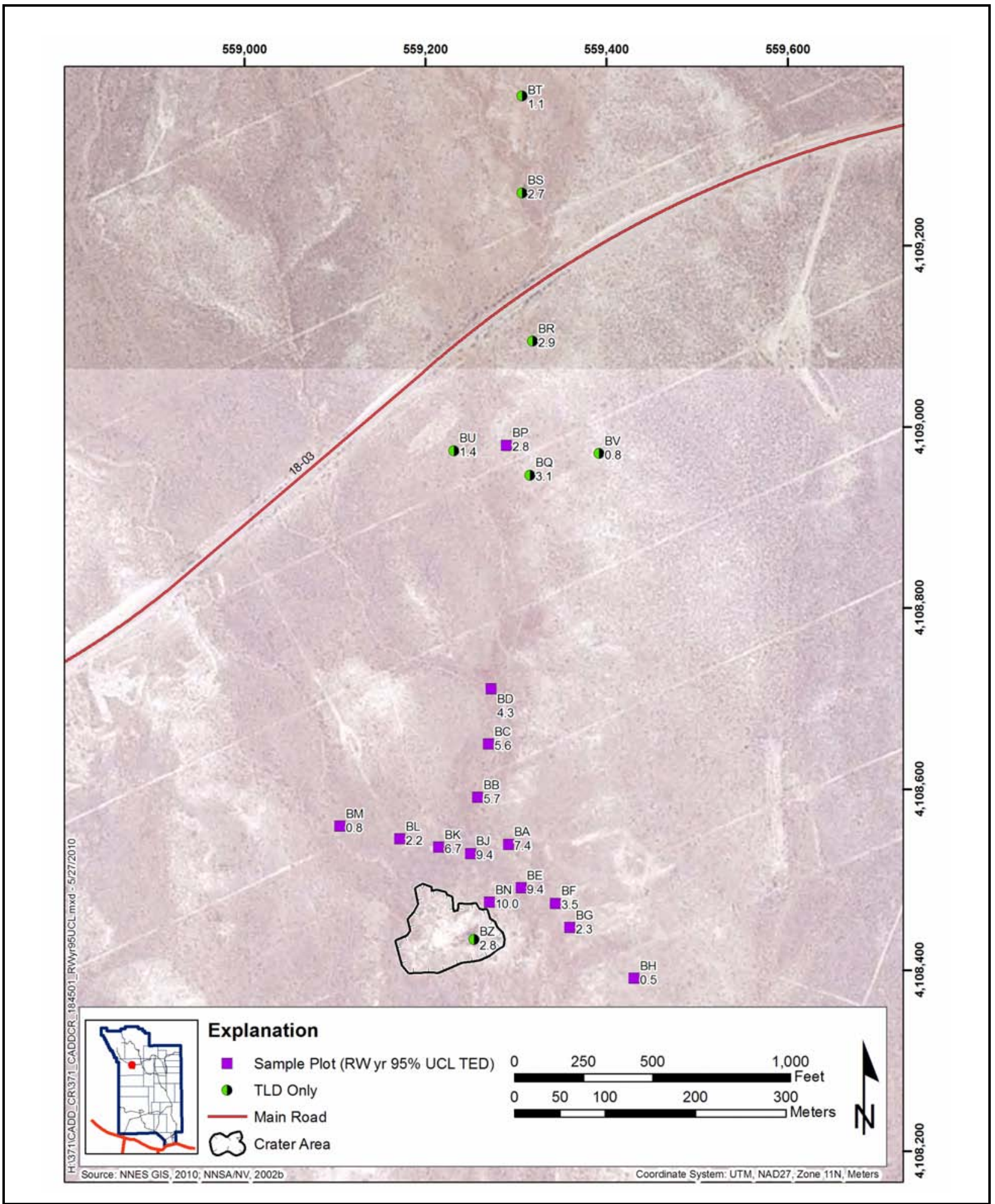

Figure A.4-5

Values for the $95 \%$ UCL of the TED at Johnnie Boy 


\section{A.4.2.4.1 Gamma-Emitting Radionuclides}

Analytical results for gamma-emitting radionuclides in the environmental sample collected at the sedimentation and ejecta locations that were detected above MDCs are presented in Table A.4-9. The radionuclide Cs-137 exceeded the PAL (12.7 pCi/g) in samples taken at all three depths for both locations in the ejecta (B03 and B04), with exceedances ranging from 78.2 to $134 \mathrm{pCi} / \mathrm{g}$. The radionuclide Eu-152 also exceeded the PAL ( $5.67 \mathrm{pCi} / \mathrm{g}$ ) in samples taken at all three depths for both locations in the ejecta (B03 and B04), with exceedances ranging from 7.8 to $28.7 \mathrm{pCi} / \mathrm{g}$. The radionuclide Eu-154 exceeded the PAL (5.4) at both surface locations ( 0.0 to $0.5 \mathrm{~cm}$ bgs) in the ejecta, with values of 5.5 at location B03 and 5.4 at location B04. However, none of the gamma-emitting radionuclide results exceeded their corresponding FALs (Table A.4-9), as established in Appendix C.

\section{A.4.2.4.2 Isotopic Radionuclides}

Analytical results for isotopic radionuclides in the environmental samples collected at the sedimentation and ejecta locations that were detected above MDCs are presented in Table A.4-9. No Sr-90 or isotopic U, Pu, or Am exceeded their respective PALs.

\section{A.4.3 Nature and Extent of Contamination}

Although COCs were not identified at this CAS under the Remote Worker scenario based on the analytical results of surface soil samples, it is assumed that subsurface contamination present in the crater (due to direct injection of radionuclides into the subsurface soil from the nuclear test) exceeds the FAL. Therefore, a corrective action of closure in place with a UR was implemented for the subsurface contamination. The UR encompasses the area of the Johnnie Boy crater as well as the ejecta mounds surrounding the crater (Figure A.4-6).

As a BMP, a decision was made to identify and administratively use restrict (administrative UR) any area where an industrial land use of the area $(2,250 \mathrm{hr} / \mathrm{yr})$ could cause a future site worker to receive a dose exceeding $25 \mathrm{mrem} / \mathrm{yr}$. This would prevent any future industrial land use activities that would require a full-time industrial site worker to be exposed to site contamination (i.e., the Industrial Use Area exposure scenario, which assumes that a site worker is exposed to site contamination for 
Table A.4-9

Page A-47 of A-64

Sample Results above MDCs at Johnnie Boy Other Releases

(Page 1 of 2)

\begin{tabular}{|c|c|c|c|c|c|c|c|c|c|c|c|c|c|c|c|}
\hline \multirow[b]{2}{*}{$\begin{array}{l}\text { Sample } \\
\text { Location }\end{array}$} & \multirow[b]{2}{*}{$\begin{array}{l}\text { Sample } \\
\text { Number }\end{array}$} & \multirow[b]{2}{*}{$\begin{array}{c}\text { Depth } \\
\text { (cm bgs) }\end{array}$} & \multicolumn{12}{|c|}{ COPCs (pCi/g) } & \multirow[b]{2}{*}{ 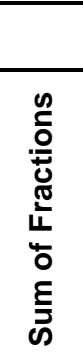 } \\
\hline & & & $\begin{array}{l}\stackrel{\text { N్ }}{N} \\
\stackrel{1}{F}\end{array}$ & $\begin{array}{l}\text { ర్ } \\
\text { ర் } \\
ن\end{array}$ & $\begin{array}{l}\stackrel{\pi}{N} \\
\stackrel{M}{+} \\
\dot{u}\end{array}$ & $\begin{array}{l}\text { Ñ } \\
\stackrel{1}{7} \\
\stackrel{1}{\perp}\end{array}$ & 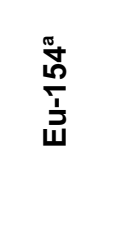 & 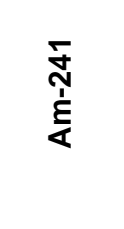 & $\begin{array}{l}\stackrel{\infty}{\infty} \\
\underset{N}{1} \\
\stackrel{1}{\alpha}\end{array}$ & 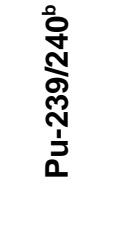 & $\begin{array}{l}\text { : } \\
\frac{1}{1} \\
\text { ") }\end{array}$ & $\begin{array}{l}\text { N্} \\
\text { J }\end{array}$ & $\begin{array}{l}\text { ஸ̊ } \\
\text { ஸे }\end{array}$ & 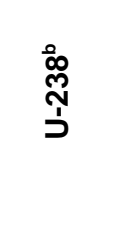 & \\
\hline \multicolumn{3}{|c|}{ FALs } & 3,292 & 122.5 & 487.4 & 255.7 & 238.7 & 9,239 & 13,900 & 12,690 & 55,220 & 131,400 & 1,709 & 9,572 & N/A \\
\hline \multirow{4}{*}{ B01 } & \multirow{2}{*}{ 371BX01 } & $0.0-5.0$ & 2.22 & -- & 0.3 & $1.86(\mathrm{~J})$ & -- & $\begin{array}{l}- \\
-\end{array}$ & -- & -- & -- & 1.27 & -- & 1.23 & $\mathrm{~N} / \mathrm{A}$ \\
\hline & & Fraction & 0.00067 & -- & 0.00062 & 0.0073 & -- & -- & -- & -- & -- & 0.00001 & -- & 0.00013 & 0.009 \\
\hline & \multirow{2}{*}{$371 \mathrm{~B} \times 02$} & $5.0-10.0$ & 2.43 & -- & -- & $1.64(\mathrm{~J})$ & -- & -- & -- & -- & -- & 1.16 & 0.052 & 1.1 & $\mathrm{~N} / \mathrm{A}$ \\
\hline & & Fraction & 0.00074 & -- & -- & 0.0064 & -- & -- & -- & -- & -- & 0.00001 & 0.00003 & 0.00011 & 0.007 \\
\hline \multirow{4}{*}{ B02 } & \multirow{2}{*}{$371 \mathrm{~B} \times 03$} & $0.0-5.0$ & 2.46 & -- & 1.82 & $1.58(\mathrm{~J})$ & -- & 0.044 & -- & 0.324 & -- & 1.18 & -- & 0.92 & $\mathrm{~N} / \mathrm{A}$ \\
\hline & & Fraction & 0.00075 & -- & 0.0037 & 0.0062 & -- & 0 & -- & 0.00003 & -- & 0.00001 & -- & 0.00010 & 0.011 \\
\hline & \multirow{2}{*}{$371 \mathrm{~B} \times 04$} & $5.0-10.0$ & 2.73 & -- & 1.57 & $1.4(\mathrm{~J})$ & -- & 0.122 & 0.131 & 0.67 & -- & 1.2 & 0.047 & 0.91 & N/A \\
\hline & & Fraction & 0.00083 & -- & 0.0032 & 0.0055 & -- & 0.00001 & 0.00001 & 0.00005 & -- & 0.00001 & 0.00003 & 0.00010 & 0.010 \\
\hline \multirow{6}{*}{ B03 } & \multirow{2}{*}{ 371BX05 } & $0.0-5.0$ & 2.54 & 1.9 & 78.2 & $28.2(\mathrm{~J})$ & $5.5(\mathrm{~J})$ & 0.104 & 0.055 & 0.94 & 7.6 & 28.1 & 0.94 & 1.2 & $\mathrm{~N} / \mathrm{A}$ \\
\hline & & Fraction & 0.00077 & 0.0155 & 0.16 & 0.11 & 0.023 & 0.00001 & 0 & 0.00007 & 0.00014 & 0.00021 & 0.00055 & 0.00013 & 0.311 \\
\hline & \multirow{2}{*}{ 371BX06 } & $5.0-10.0$ & 2.03 & 1.16 & 91 & $11.1(\mathrm{~J})$ & $2.56(\mathrm{~J})$ & -- & -- & 0.66 & 14.1 & 14.3 & 0.51 & 0.95 & $\mathrm{~N} / \mathrm{A}$ \\
\hline & & Fraction & 0.00062 & 0.0095 & 0.19 & 0.043 & 0.011 & -- & -- & 0.00005 & 0.00026 & 0.00011 & 0.0003 & 0.00010 & 0.252 \\
\hline & \multirow{2}{*}{$371 B \times 10$} & $25.0-30.0$ & 2.67 & 0.39 & 98 & $7.8(\mathrm{~J})$ & -- & -- & 0.096 & 0.56 & 6.5 & 5.04 & 0.202 & 0.95 & $\mathrm{~N} / \mathrm{A}$ \\
\hline & & Fraction & 0.00081 & 0.0032 & 0.201 & 0.031 & -- & -- & 0.00001 & 0.00004 & 0.00012 & 0.00004 & 0.00012 & 0.00010 & 0.236 \\
\hline
\end{tabular}


Table A.4-9

Page A-48 of A-64

Sample Results above MDCs at Johnnie Boy Other Releases

(Page 2 of 2)

\begin{tabular}{|c|c|c|c|c|c|c|c|c|c|c|c|c|c|c|c|}
\hline \multirow[b]{2}{*}{$\begin{array}{l}\text { Sample } \\
\text { Location }\end{array}$} & \multirow[b]{2}{*}{$\begin{array}{l}\text { Sample } \\
\text { Number }\end{array}$} & \multirow[b]{2}{*}{$\begin{array}{c}\text { Depth } \\
\text { (cm bgs) }\end{array}$} & \multicolumn{12}{|c|}{ COPCs (pCi/g) } & \multirow[b]{2}{*}{ 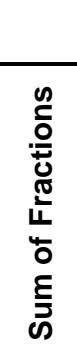 } \\
\hline & & & $\begin{array}{l}\stackrel{\text { N్ }}{\underset{N}{N}} \\
\stackrel{1}{F}\end{array}$ & 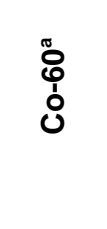 & 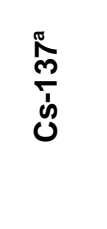 & 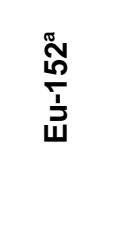 & 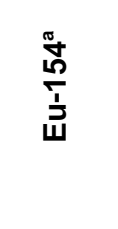 & 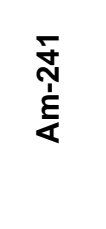 & $\begin{array}{l}\stackrel{0}{\infty} \\
\stackrel{్}{N} \\
\grave{1} \\
\mathbb{1}\end{array}$ & 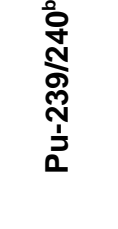 & $\begin{array}{l}\text { क̊ } \\
\frac{1}{1} \\
\bar{n}\end{array}$ & $\begin{array}{l}\stackrel{\text { N }}{J} \\
\text { jo }\end{array}$ & $\begin{array}{l}\stackrel{\mathscr{N}}{N} \\
\stackrel{N}{J}\end{array}$ & $\begin{array}{l}\stackrel{\circ}{0} \\
\stackrel{N}{N} \\
\stackrel{J}{J}\end{array}$ & \\
\hline \multicolumn{3}{|c|}{ FALs } & 3,292 & 122.5 & 487.4 & 255.7 & 238.7 & 9,239 & 13,900 & 12,690 & 55,220 & 131,400 & 1,709 & 9,572 & N/A \\
\hline \multirow{6}{*}{ B04 } & \multirow{2}{*}{ 371BX11 } & $0.0-5.0$ & 2.12 & 2.18 & 86.7 & $28.7(\mathrm{~J})$ & $5.4(\mathrm{~J})$ & -- & 0.075 & 1.2 & 9.1 & 30.1 & 1.01 & 1.09 & $\mathrm{~N} / \mathrm{A}$ \\
\hline & & Fraction & 0.00064 & 0.018 & 0.18 & 0.11 & 0.023 & -- & 0.00001 & 0.00009 & 0.00016 & 0.00023 & 0.00059 & 0.00011 & 0.332 \\
\hline & \multirow{2}{*}{$371 \mathrm{~B} \times 12$} & $5.0-10.0$ & 2.69 & 2.16 & 106 & $23.5(\mathrm{~J})$ & $4.01(\mathrm{~J})$ & -- & -- & 1.04 & 15.8 & 26.7 & 0.85 & 1.14 & $\mathrm{~N} / \mathrm{A}$ \\
\hline & & Fraction & 0.00082 & 0.018 & 0.22 & 0.092 & 0.017 & -- & -- & 0.00008 & 0.00029 & 0.0002 & 0.0005 & 0.00012 & 0.346 \\
\hline & \multirow{2}{*}{$371 \mathrm{~B} \times 13$} & $25.0-30.0$ & -- & 1.11 & 134 & $16.8(\mathrm{~J})$ & -- & -- & -- & 0.55 & 13.7 & 13.9 & 0.45 & 1.16 & $\mathrm{~N} / \mathrm{A}$ \\
\hline & & Fraction & -- & 0.0091 & 0.27 & 0.066 & -- & -- & -- & 0.00004 & 0.00025 & 0.00011 & 0.00026 & 0.00012 & 0.350 \\
\hline
\end{tabular}

${ }^{\mathrm{a} G a m m a-e m i t t i n g ~ r a d i o n u c l i d e ~}$ bIsotope

$\mathrm{J}=$ Estimated value

-- = Not detected above MDCs 


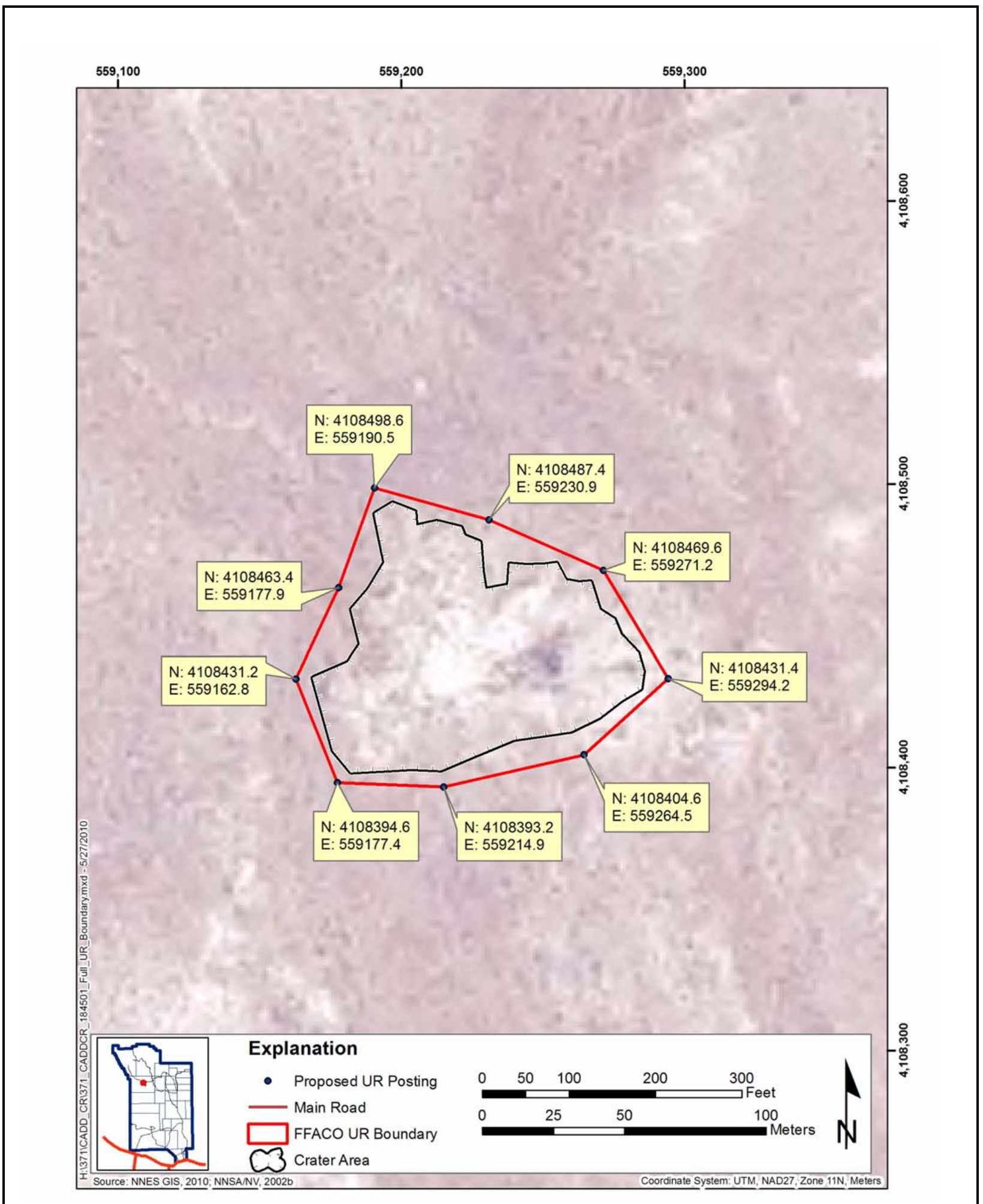

Figure A.4-6

Johnnie Boy UR Area 
$10 \mathrm{hr} /$ day and 225 day/yr or 2,250 hr/yr). At Johnnie Boy, the TED from surface soils exceed a dose of $25 \mathrm{mrem} / \mathrm{yr}$ under the Industrial Area scenario at plots BA, BB, BC, BD, BE, BJ, BK and BN.

To estimate the area that would encompass all locations where dose could exceed 25 mrem for a full-time industrial worker, the 95 percent UCL of the TED from each sampled location was correlated to isopleth gross count values from the 2008 flyover radiation survey (NNSA/NSO, 2009a). This correlation, shown in Figure A.4-7, indicates that 95 percent UCL of the TED value of 25 mrem/IA-yr corresponds to a gross count flyover survey value of approximately 36,000 counts per second (cps). As shown in Figure A.4-8, the gross count flyover survey isopleth of 36,000 cps encompasses all sample plots that have a 95 percent UCL of the TED that exceed 25 mrem/IA-yr.

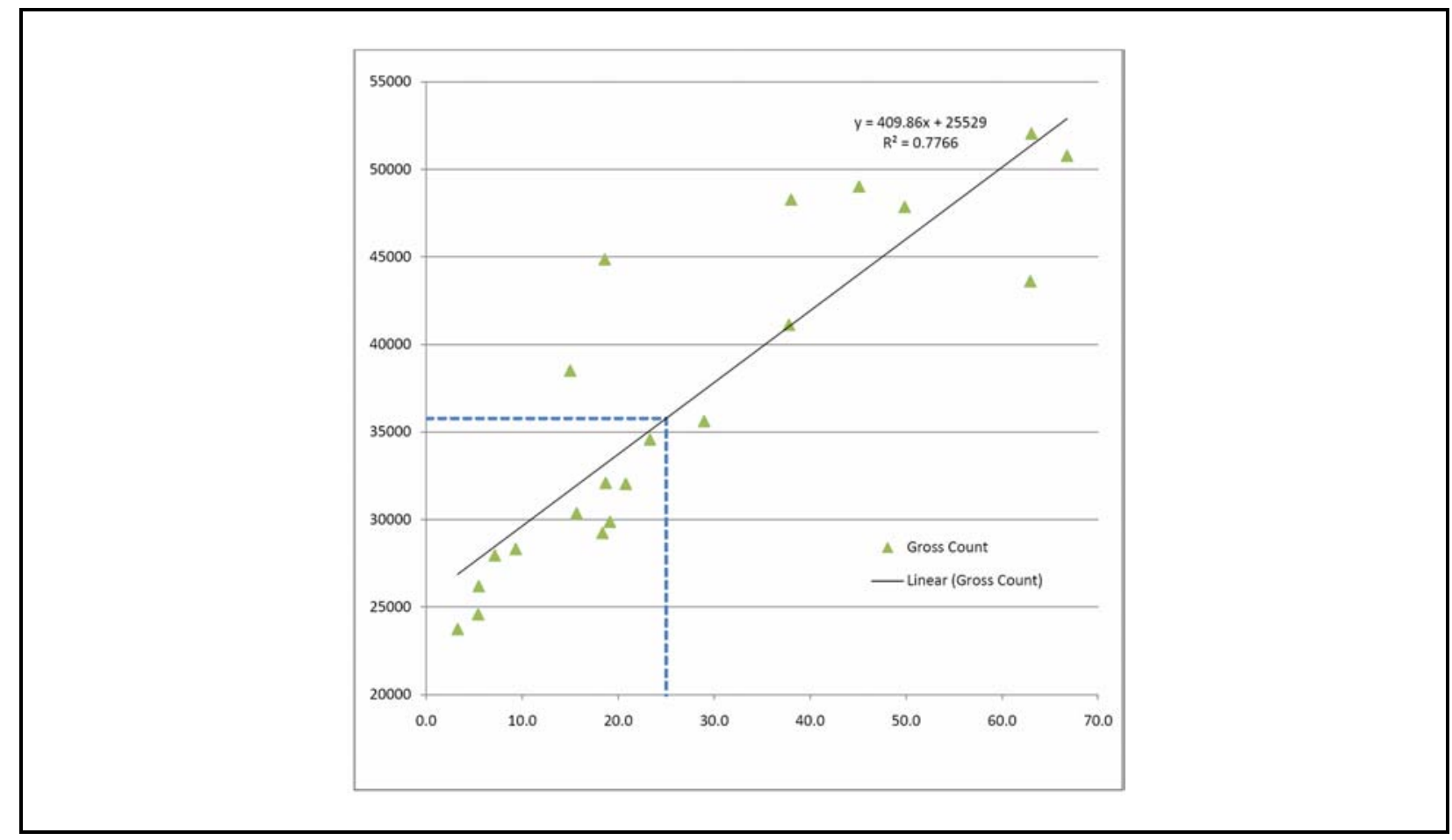

\section{Figure A.4-7 \\ Method 1: Correlation of the 95\% UCL of the TED to Gross Count Flyover Value at Johnnie Boy}

Another method used to estimate the area that would encompass all locations where dose could exceed 25 mrem for a full-time industrial worker (and the method stipulated in the CAIP [NNSA/NSO, 2009b]), was to correlate the 95 percent UCL of the TED from each sampled location to distance along each of the sample plot vectors. Using this method, the following distances were 


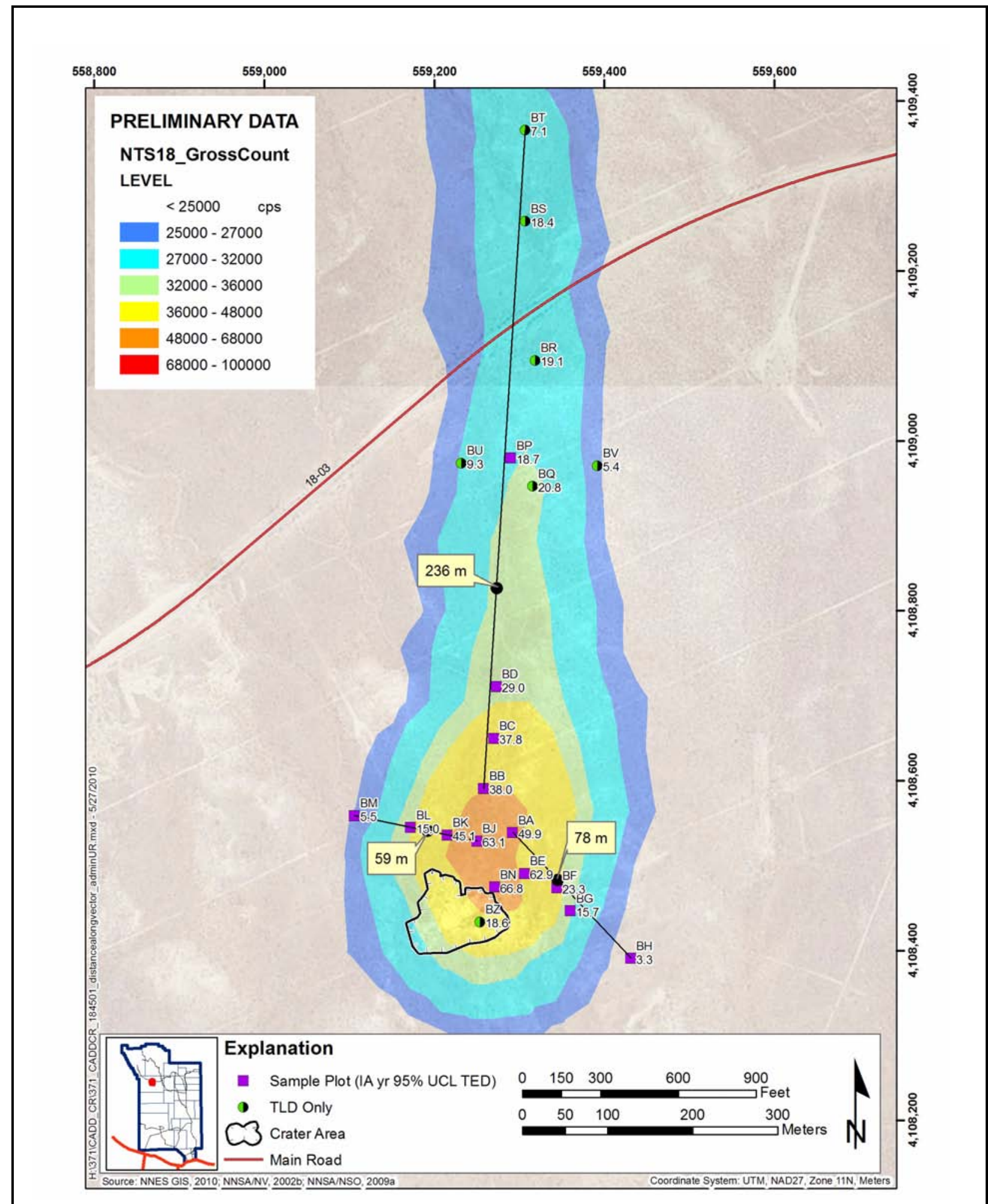

Figure A.4-8

Johnnie Boy Correlation of Gross Count Flyover Isopleth Values to $95 \%$ UCL of TED and Distance along Vectors 
determined from the innermost plot along each vector to the location along each vector corresponding to a 95 percent UCL of the TED value of 25 mrem/IA-yr (as shown on Figure A.4-9):

- Northern vector - $236 \mathrm{~m}$

- Southeastern vector - $78 \mathrm{~m}$

- Western vector - $59 \mathrm{~m}$

As shown in Figure A.4-8, the gross count flyover survey isopleth of 32,000 cps encompasses these distances.

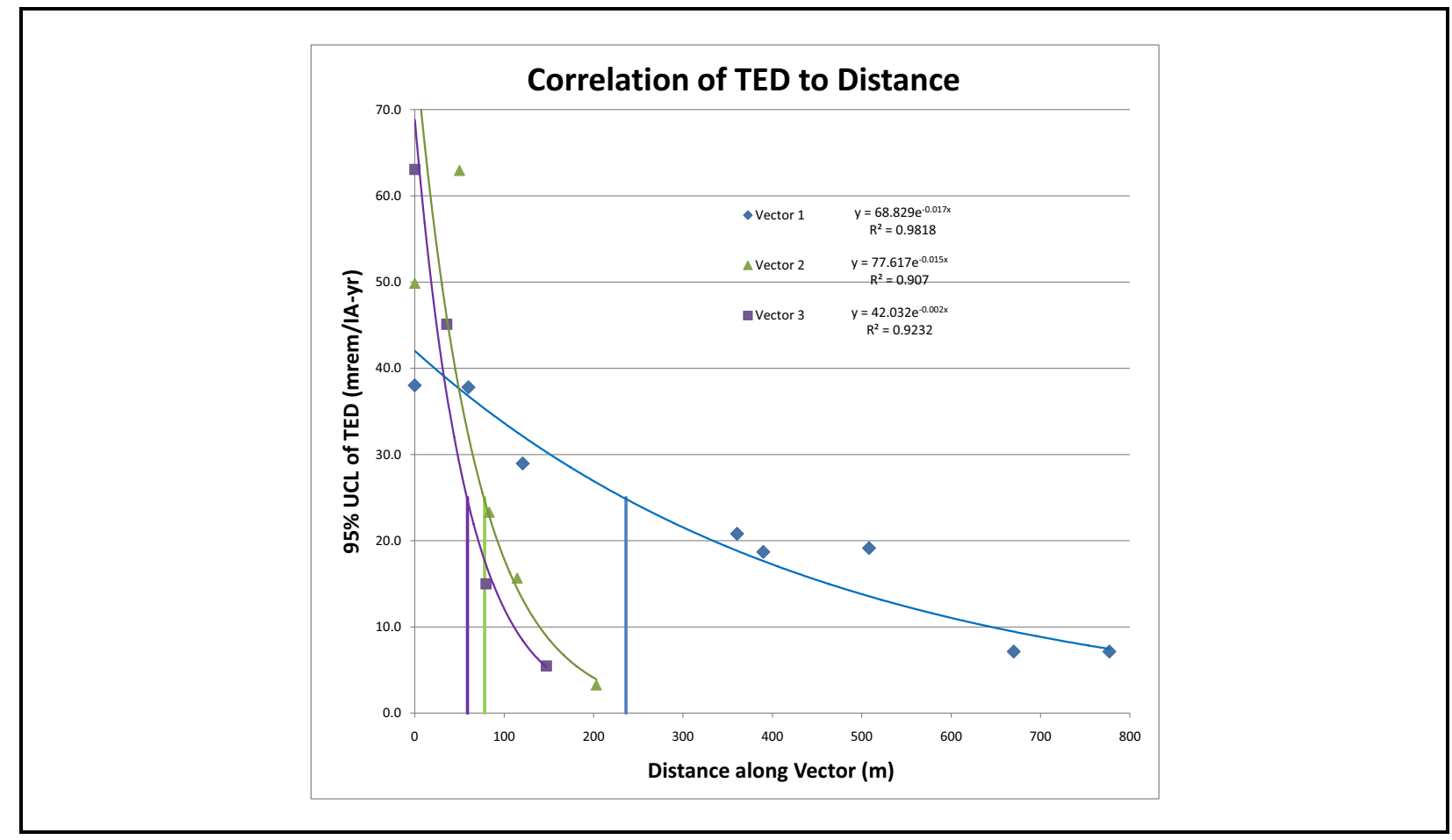

Figure A.4-9

Method 2: Correlation of the 95\% UCL of the TED to Distance along Vectors at Johnnie Boy

Of these two methods, the most conservative estimate of the area that would encompass all locations where dose could exceed 25 mrem for a full-time industrial worker is the 32,000 cps isopleth from the distance correlation method (Figure A.4-9). As a BMP, an administrative UR was implemented for this area to prevent future industrial land use of this area that would cause a full-time industrial site worker to be present within this area for an annual duration of 2,250 hr/yr (Figure A.4-10). 


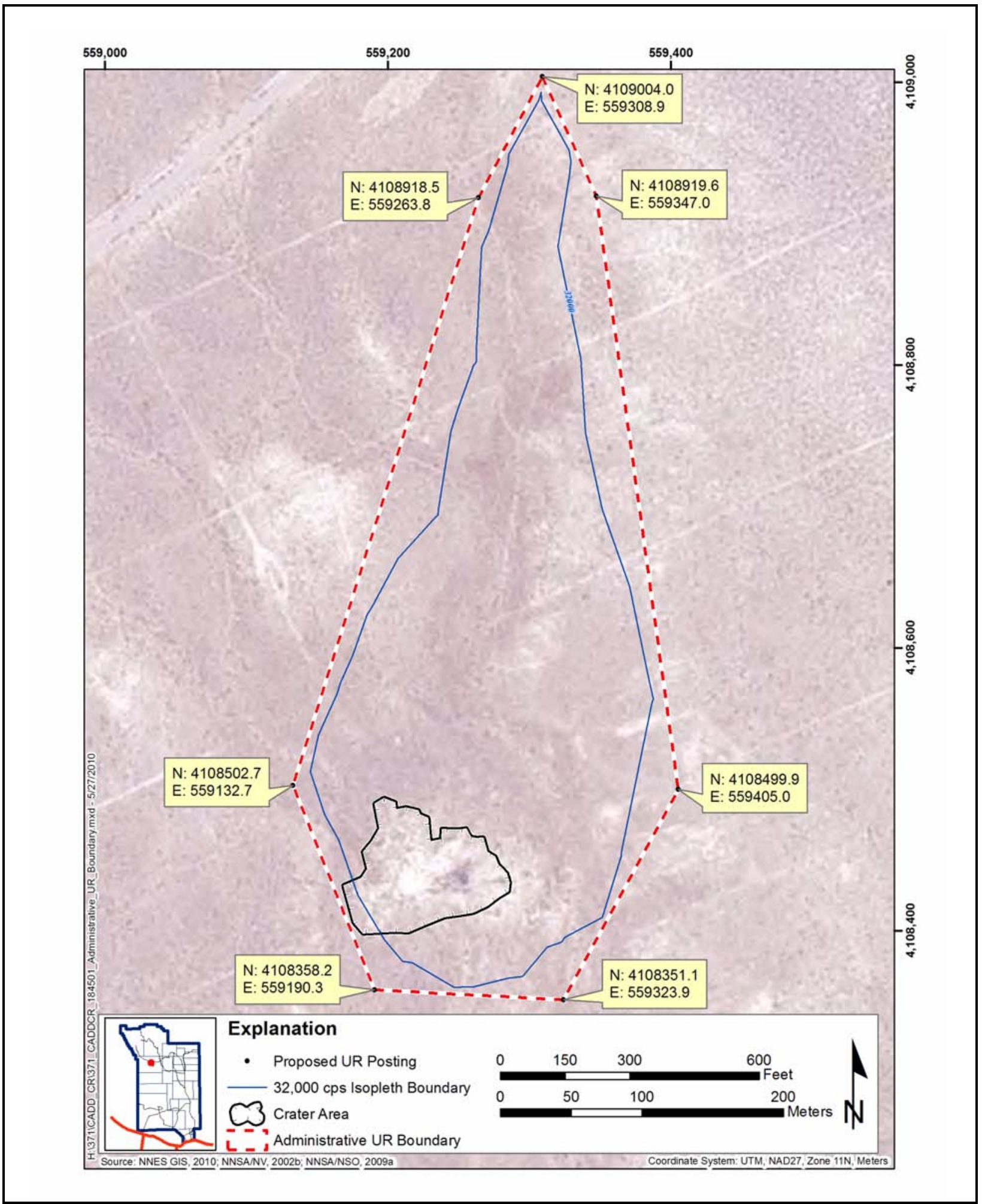

Figure A.4-10

Johnnie Boy Administrative UR Area 


\section{A.4.4 Revised Conceptual Site Model}

The CAIP requirements (NNSA/NSO, 2009b) were met at this CAS. The information gathered

during the CAI supports the CSM as presented in the CAIP for CAU 371. Therefore, no revisions were necessary to the CSM. 


\section{A.5.0 Waste Management}

Waste management activities were conducted as specified in the CAIP (NNSA/NSO, 2009b).

Investigation-derived wastes (IDWs) generated during the CAI were characterized based on process knowledge and FSRs. Controls were in place to minimize the use of hazardous materials and the unnecessary generation of hazardous and/or mixed waste.

\section{A.5.1 Investigation-Derived Waste}

Investigation-derived waste generated during the field activities for CAU 371 included disposable personal protective equipment (PPE), disposable sampling equipment, and empty sample containers. The IDWs, which were collected daily, was field screened as generated to comply with the radiological release limits of Table 4-2 of the NTS Radiological Control Manual (NNSA/NSO, 2010) to verify that removable contamination was not present at the site. The waste was bagged, labeled, and placed in a roll-off container at Building 23-153 for disposition at the NTS Area 9 U10c Industrial Landfill. 


\section{A.6.0 Quality Assurance}

This section contains a summary of QA/QC measures implemented during the sampling and analysis activities conducted in support of the CAU 371 CAI. The following sections discuss the data validation process, QC samples, and nonconformances. A detailed evaluation of the DQIs is presented in Appendix B.

Laboratory analyses were conducted for samples used in the decision-making process to provide a quantitative measurement of any contaminants of potential concern (COPCs) present. Rigorous QA/QC was implemented for all laboratory samples, including documentation, verification and validation of analytical results, and affirmation of DQI requirements related to laboratory analysis. Detailed information regarding the QA program is contained in the Industrial Sites QAPP (NNSA/NV, 2002a).

\section{A.6.1 Data Validation}

Data validation was performed in accordance with the Industrial Sites QAPP (NNSA/NV, 2002a) and approved protocols and procedures. All laboratory data from samples collected and analyzed for CAU 371 were evaluated for data quality in a tiered process and are presented in Sections A.6.1.1 through A.6.1.3. Data were reviewed to ensure that samples were appropriately processed and analyzed, and the results were evaluated using validation criteria. Documentation of the data qualifications resulting from these reviews is retained in project files as a hard copy and electronic media.

All data analyzed as part of this investigation were subjected to Tier I and Tier II evaluations. A Tier III evaluation was performed on 6.5 percent of the data analyzed.

\section{A.6.1.1 Tier I Evaluation}

Tier I evaluation for radiochemical analysis examines, but is not limited to:

- Sample count/type consistent with chain of custody.

- Analysis count/type consistent with chain of custody.

- Correct sample matrix. 
- Significant problems and/or nonconformances stated in cover letter or case narrative.

- Completeness of certificates of analysis.

- Completeness of Contract Laboratory Program (CLP) or CLP-like packages.

- Completeness of signatures, dates, and times on chain of custody.

- Condition-upon-receipt variance form included.

- Requested analyses performed on all samples.

- Date received/analyzed given for each sample.

- Correct concentration units indicated.

- Electronic data transfer supplied.

- Results reported for field and laboratory QC samples.

- Whether or not the deliverable met the overall objectives of the project.

\section{A.6.1.2 Tier II Evaluation}

Tier II evaluation for radiochemical analysis examines, but is not limited to:

- Correct detection limits achieved.

- Blank contamination evaluated and, if significant, qualifiers are applied to sample results.

- Certificate of Analysis consistent with data package documentation.

- Quality control sample results (duplicates, laboratory control samples [LCSs], laboratory blanks) evaluated and used to determine laboratory result qualifiers.

- Sample results, uncertainty, and MDC evaluated.

- Detector system calibrated with National Institute of Standards and Technology (NIST)traceable sources.

- Calibration sources preparation was documented, demonstrating proper preparation and appropriateness for sample matrix, emission energies, and concentrations.

- Detector system response to daily or weekly background and calibration checks for peak energy, peak centroid, peak full-width half-maximum, and peak efficiency, depending on the detection system.

- Tracers NIST-traceable, appropriate for the analysis performed, and recoveries that met QC requirements.

- Documentation of all QC sample preparation complete and properly performed.

- Spectra lines, photon emissions, particle energies, peak areas, and background peak areas support the identified radionuclide and its concentration. 


\section{A.6.1.3 Tier III Evaluation}

The Tier III review is an independent examination of the Tier II evaluation. A Tier III review of 6.5 percent of the sample radiological data was performed by TLI Solutions, Inc., in Golden, Colorado. Tier II and Tier III results were compared and where differences are noted, data were reviewed and changes were made accordingly. This review included the following additional evaluations:

- Review:

- Case narrative, chain of custody, and sample receipt forms

- Lab qualifiers (applied appropriately)

- Method of analyses performed as dictated by the chain of custody

- Raw data, including chromatograms, instrument printouts, preparation logs, and analytical logs

- Manual integrations to determine whether the response is appropriate

- Data package for completeness

- Determine sample results qualifiers through the evaluation of (but not limited to):

- Tracers and QC sample results (e.g., duplicates, LCSs, blanks, matrix spikes) evaluated and used to determine sample results qualifiers

- Sample preservation, sample preparation/extraction and run logs, sample storage, and holding time

- Instrument and detector tuning

- Initial and continuing calibrations

- Calibration verification (initial, continuing, second source)

- Retention times

- Second column and/or second detector confirmation

- Mass spectra interpretation 
- Interference check samples and serial dilutions

- Post digestion spikes and method of standard additions

- Breakdown evaluations

- Perform calculation checks of:

- At least one analyte per QC sample and its recovery

- At least one analyte per initial calibration curve, continuing calibration verification, and second source recovery

- At least one analyte per sample that contains positive results (hits); radiochemical results only require calculation checks on activity concentrations (not error)

- Verify that target compound detects identified in the raw data are reported on the results form.

- Document any anomalies for the laboratory to clarify or rectify. The contractor should be notified of any anomalies.

\section{A.6.2 Field QC Samples}

Field QC samples consisted of six full laboratory QCs collected and submitted for analysis by the laboratory analytical methods shown in Table A.2-1. The QC samples were assigned individual sample numbers and sent to the laboratory "blind.” Full laboratory QC samples are used to measure accuracy and precision associated with the matrix (see Appendix B for further discussion).

During the CAI, six FDs were also sent as blind samples to the laboratory to be analyzed for the investigation parameters listed in Table A.2-1. For these samples, the duplicate results precision (i.e., relative percent differences [RPDs] between the environmental sample results and their corresponding FD sample results) were evaluated.

\section{A.6.2.1 Laboratory QC Samples}

Analysis of QC preparation blanks, LCSs, and laboratory duplicate samples was performed on each sample delivery group (SDG) for radionuclides. Initial and continuing calibration and LCSs were performed for each SDG. The results of these analyses were used to qualify associated environmental 
sample results. Documentation of data qualifications resulting from the application of these guidelines is retained in project files as both hard copy and electronic media.

\section{A.6.3 Field Nonconformances}

There were no field nonconformances identified for the CAI.

\section{A.6.4 Laboratory Nonconformances}

Laboratory nonconformances are generally due to inconsistencies in the analytical instrumentation operation, sample preparations, extractions, missed holding times, and fluctuations in internal standard and calibration results. Nonconformances issued by the laboratories may or may not have resulted in qualifying data. Laboratory nonconformances were accounted for and resolved during the data validation process.

\section{A.6.5 TLD Data Validation}

The use of a TLD to determine an individual's external exposure is the standard in radiation safety and serves as the "legal dose of record" when other measurements are not available. Specifically, 10 CFR Part 835.402 (CFR, 2009) indicates that personal dosimeters shall be provided to monitor individual exposures and that the monitoring program that uses the dosimeters shall be accredited in accordance with a DOE Laboratory Accreditation Program, as was the case for the TLDs used at CAU 371.

The TLDs were exposed at the CAU 371 sample plots for an entire exposure duration exceeding the 2,250 hours of the Industrial Area exposure scenario. 


\section{A.7.0 Summary}

Radionuclide contaminants detected in environmental samples during the CAI were evaluated against FALs to determine the nature and extent of COCs for CAU 371. Assessment of the data generated from surface soil samples indicates that although surface radiological contamination at the site exceeds the PALs (based on the Industrial Area exposure scenario) it does not exceed the FALs (based on the Remote Work Area exposure scenario). However, subsurface contamination is assumed to be present at both CASs that exceeds the FALs. Therefore corrective action is required. The following summarizes the results for each CAS.

\section{CAS 11-23-05, Pin Stripe Contamination Area}

Based on field observations and analytical results for surface soil (0 to $5 \mathrm{~cm}$ bgs) samples collected at this CAS, the surface radiological contamination at the site does not exceed the FAL for the radiological dose (25 mrem/RW-yr). However, it is assumed that subsurface contamination present in the fissure exceeds the FAL and could be uncovered if the site were to be excavated in the future. Therefore, a corrective action is required. The selected corrective action (based on the corrective action evaluation presented in Appendix E) for the subsurface contamination is closure in place with a UR. A UR was established that encompasses the area of the Pin Stripe subsidence crater as well as the identified surface expression of the fissure (Figure A.3-5).

\section{CAS 18-45-01, U-18j-2 Crater (Johnnie Boy)}

Based on field observations and analytical results for surface soil (0 to $5 \mathrm{~cm}$ bgs) samples collected at this CAS, the surface radiological contamination at the site does not exceed the FAL for the radiological dose (25 mrem/RW-yr). However, it is assumed that subsurface contamination present in the crater exceeds the FAL due to direct injection of radionuclides into the subsurface soil from the nuclear test. Therefore, a corrective action is required. The selected corrective action (based on the corrective action evaluation presented in Appendix E) for the subsurface contamination is closure in place with a UR. A UR was established that encompasses the area of the Johnnie Boy crater as well as the ejecta mounds surrounding the crater (Figure A.4-6). 


\section{A.8.0 References}

BN, see Bechtel Nevada.

Bechtel Nevada. 1999. An Aerial Radiological Survey of the Nevada Test Site, DOE/11718--324. Prepared for U.S. Department of Energy, Nevada Operations Office. Las Vegas, NV: Remote Sensing Laboratory.

CFR, see Code of Federal Regulations.

Code of Federal Regulations. 2009. Title 10 CFR Part 835, “Occupational Radiation Protection.” Washington, DC: U.S. Government Printing Office.

DOE, see U.S. Department of Energy.

DOE/NV, see U.S. Department of Energy, Nevada Operations Office.

DRI, see Desert Research Institute.

Desert Research Institute. 1983. Radionuclide Inventory and Distribution Program: The Galileo Area, DOE/NV/10162-14. Prepared by R.D. McArthur and J.F. Kordas. Las Vegas, NV.

Desert Research Institute. 1985. Nevada Test Site Radionuclide Inventory and Distribution Program: Report \#2, Areas 2 and 4, DOE/NV/10162-20. Prepared by R.D. McArthur and J.F. Kordas. Las Vegas, NV.

EPA, see U.S. Environmental Protection Agency.

Gilbert, R.O., E.H. Essington, D.N. Brady, P.G. Doctor, and L.L Eberhardt. 1977. "Statistical Activities during 1976 and the Design and Initial Analysis of Nuclear Site Studies.” In Transuranics in Desert Ecosystems, NVO-181. pp. 331-366. November. Las Vegas, NV: U.S. Department of Energy, Nevada Operations Office.

Gray, K.J., D.S. Shafer, K. Self, C. Martin, and R. McArthur. 2007. Radionuclide Inventory and Distribution Program (RIDP) Database, Rev. 2. April. Las Vegas, NV.

NNES, see Navarro Nevada Environmental Services, LLC.

NNES GIS, see Navarro Nevada Environmental Services Geographic Information Systems.

NNSA/NSO, see U.S. Department of Energy, National Nuclear Security Administration Nevada Site Office. 
NNSA/NV, see U.S. Department of Energy, National Nuclear Security Administration Nevada Operations Office.

Navarro Nevada Environmental Services, LLC. 2009. Statement of Work for Analytical Laboratories, Section C. Las Vegas, NV.

Navarro Nevada Environmental Services Geographic Information Systems. 2010. ESRI ArcGIS Software.

PNNL, see Pacific Northwest National Laboratory.

Pacific Northwest National Laboratory. 2007. Visual Sample Plan, Version 5.0 User’s Guide, PNNL-16939. Richland, WA.

Tamura, T. 1977. "Plutonium Distribution in a Desert Pavement-Desert Mound Soil System in Area 11.” In Environmental Plutonium on the Nevada Test Site and Environs, NVO-171. June. Las Vegas, NV: Energy Research and Development Administration.

U.S. Department of Energy. 1997. The Procedures Manual of the Environmental Measurements Laboratory, HASL-300. 28th Ed., Vol. I. February. New York, NY.

U.S. Department of Energy, National Nuclear Security Administration Nevada Operations Office. 2002a. Industrial Sites Quality Assurance Project Plan, Nevada Test Site, Nevada, Rev. 3, DOE/NV--372. Las Vegas, NV.

U.S. Department of Energy, National Nuclear Security Administration Nevada Operations Office. 2002b. Nevada Test Site Orthophoto Site Atlas, DOE/NV/11718--604. Prepared by Bechtel Nevada. Las Vegas, NV.

U.S. Department of Energy, National Nuclear Security Administration Nevada Site Office. 2006. Industrial Sites Project Establishment of Final Action Levels, Rev. 0, DOE/NV--1107. Las Vegas, NV.

U.S. Department of Energy, National Nuclear Security Administration Nevada Site Office. 2009a. An Aerial Radiological Survey of Selected Areas of Area 18 - Nevada Test Site, DOE/NV/25946--767. Prepared by C. Lyons for National Security Technologies, LLC. Las Vegas, NV: Remote Sensing Laboratory.

U.S. Department of Energy, National Nuclear Security Administration Nevada Site Office. 2009b. Corrective Action Investigation Plan for Corrective Action Unit 371: Johnnie Boy Crater and Pin Stripe, Nevada Test Site, Nevada, Rev. 0, DOE/NV--1310. Las Vegas, NV.

U.S. Department of Energy, National Nuclear Security Administration Nevada Site Office. 2010. Nevada Test Site Radiological Control Manual, DOE/NV/25946--801, Rev. 1. Prepared by Radiological Control Managers’ Council. Las Vegas, NV. 
U.S. Department of Energy, Nevada Operations Office. 1996. Final Environmental Impact Statement for the Nevada Test Site and Off-Site Locations in the State of Nevada, DOE/EIS-0243. Las Vegas, NV.

U.S. Environmental Protection Agency. 1980. Prescribed Procedures for Measurement of Radioactivity in Drinking Water, EPA 600/4-80-032. Cincinnati, OH: Environmental Monitoring and Support Laboratory Office of Research and Development.

Yu, C., A.J. Zielen, J.J. Cheng, D.J. LePoire, E. Gnanapragasam, S. Kamboj, J. Arnish, A. Wallo III, W.A. Williams, and H. Peterson. 2001. User's Manual for RESRAD Version 6, ANL/EAD-4. Argonne, IL: Argonne National Laboratory, Environmental Assessment Division. (Version 6.4 released in December 2007.) 


\section{Appendix B}

\section{Data Assessment}




\section{B.1.0 Data Assessment}

The DQA process is the scientific evaluation of the actual investigation results to determine whether the DQO criteria established in the CAU 371 CAIP (NNSA/NSO, 2009) were met and whether DQO decisions can be resolved at the desired level of confidence. The DQO process ensures that the right type, quality, and quantity of data will be available to support the resolution of those decisions at an appropriate level of confidence. Using both the DQO and DQA processes help to ensure that DQO decisions are sound and defensible.

The DQA involves five steps that begin with a review of the DQOs and end with an answer to the DQO decisions. The five steps are briefly summarized as follows:

Step 1: Review DQOs and Sampling Design - Review the DQO Process to provide context for analyzing the data. State the primary statistical hypotheses; confirm the limits on decision errors for committing false negative (Type I) or false positive (Type II) decision errors; and review any special features, potential problems, or deviations to the sampling design.

Step 2: Conduct a Preliminary Data Review - Perform a preliminary data review by reviewing QA reports and inspecting the data both numerically and graphically, validating and verifying the data to ensure that the measurement systems performed in accordance with the criteria specified, and using the validated dataset to determine whether the quality of the data is satisfactory.

Step 3: Select the Test - Select the test based on the population of interest, population parameter, and hypotheses. Identify the key underlying assumptions that could cause a change in one of the DQO decisions.

Step 4: Verify the Assumptions - Perform tests of assumptions. If data are missing or are censored, determine the impact on DQO decision error.

Step 5: Draw Conclusions from the Data - Perform the calculations required for the test. 


\section{B.1.1 Review DQOs and Sampling Design}

This section contains a review of the DQO process presented in Appendix A of the CAU 371 CAIP (NNSA/NSO, 2009). The DQO decisions are presented with the DQO provisions to limit false negative or false positive decision errors. Special features, potential problems, or any deviations to the sampling design are also presented.

\section{B.1.1.1 Decision I}

The Decision I statement as presented in the CAU 371 CAIP for both primary and other releases is: “Is any COC associated with the CAS present in environmental media?” (NNSA/NSO, 2009).

\section{Decision I Rules:}

- If the population parameter of any COPC in the Decision I population of interest (defined in Step 4 of the DQO) exceeds the corresponding FAL, then that COPC is identified as a COC, and Decision II samples will be collected, else no further investigation is needed for that release in that population.

- If COC contamination is inconsistent with the CSM or extends beyond the spatial boundaries identified in Section A.6.2 of the CAU 371 CAIP, then work will be suspended and the investigation strategy will be reconsidered, else the decision will be to continue sampling to define the extent.

- If a COC exists at any CAS, then a corrective action will be determined, else no further action will be necessary.

- If a waste is present that, if released, has the potential to cause the future contamination of site environmental media, then a corrective action will be identified, else no further action will be necessary.

\section{B.1.1.1.1 DQO Provisions To Limit False Negative Decision Error}

A false negative decision error (when it is concluded that the contamination is not present when it actually is) was controlled by meeting the following criteria:

1a. For Decision I, having a high degree of confidence that sample locations selected will identify COCs if present anywhere within the CAS.

1b. Maintenance of a false negative decision error rate of 0.05 (probabilistic sampling). 
2. Having a high degree of confidence that analyses conducted will be sufficient to detect any COCs present in the samples at an acceptable level of sensitivity.

3. Having a high degree of confidence that the dataset is of sufficient quality and completeness.

\section{Criterion 1a:}

The locations for sampling the fissure area at Pin Stripe and the ejecta and sedimentation areas at Johnnie Boy were selected based upon the criterion of visual field observations (visible sedimentation areas within a wash downgradient of Johnnie Boy GZ and elevated radiological readings from the GWSs) (Section A.2.1).

To resolve Decision I for the primary release at Pin Stripe (as stipulated in the DQOs), sample plot locations were placed at the highest radiological readings as detected during the GWSs. To resolve Decision I for the primary release at Johnnie Boy (as stipulated in the DQOs), sample plot locations were placed at the areas of highest radiological readings from the 1994 aerial radiological survey (BN, 1999) (Section A.2.1).

\section{Criterion 1b:}

Control of the false negative decision error for the sample plot was accomplished by ensuring that:

- The population distributions fit the applied UCL determination method.

- A sufficient sample size was collected.

- The actual standard deviation is known.

- Analyses conducted were sufficient to detect any COCs present in samples.

The minimum number of samples required from each plot was calculated from the statistics generated from the TED for each of the samples collected in the plot (Tables B.1-1 and B.1-2). This calculation was conducted as stipulated in the CAU 371 CAIP (NNSA/NSO, 2009) based on the following parameters:

- A false rejection rate of 5 percent.

- A false acceptance rate of 20 percent.

- The maximum acceptable gray region set to one half the FAL (12.5 mrem/yr).

- The calculated standard deviation of each plot. 
Table B.1-1

Input Values and Determined Minimum Number of Samples for CAU 371, Pin Stripe

\begin{tabular}{|c|c|c|c||}
\hline \multicolumn{3}{|c|}{ Soil Samples } \\
\hline Plot & $\begin{array}{c}\text { Standard } \\
\text { Deviation }\end{array}$ & $\begin{array}{c}\text { Minimum } \\
\text { Sample Size }\end{array}$ & $\begin{array}{c}\text { Samples } \\
\text { Collected }\end{array}$ \\
\hline \hline $\mathrm{AA}$ & 0.0037 & 1.4 & 5 \\
\hline $\mathrm{AB}$ & 0.0145 & 1.4 & 4 \\
\hline $\mathrm{AC}$ & 0.0079 & 1.4 & 5 \\
\hline $\mathrm{AE}$ & 0.0008 & 1.4 & 4 \\
\hline $\mathrm{AF}$ & 0.0002 & 1.4 & 4 \\
\hline
\end{tabular}

Note: The actual required minimum number of samples calculated by the one-sample t-test (EPA, 2006; PNNL, 2007) was less than 3 . The minimum number of samples required to calculate statistics is 3 .

Table B.1-2

Input Values and Determined Minimum Number of Samples for CAU 371, Johnnie Boy

\begin{tabular}{|c|c|c|c||}
\hline \multicolumn{2}{|c|}{ Soil Samples } \\
\hline Plot & $\begin{array}{c}\text { Standard } \\
\text { Deviation }\end{array}$ & $\begin{array}{c}\text { Minimum } \\
\text { Sample Size }\end{array}$ & $\begin{array}{c}\text { Samples } \\
\text { Collected }\end{array}$ \\
\hline \hline BA & 0.001 & 1.4 & 5 \\
\hline BB & 0.0007 & 1.4 & 4 \\
\hline BC & 0.0265 & 1.4 & 4 \\
\hline BD & 0.0011 & 1.4 & 4 \\
\hline BE & 0.0017 & 1.4 & 4 \\
\hline BF & 0.0005 & 1.4 & 4 \\
\hline BG & 0.0008 & 1.4 & 5 \\
\hline BH & 0.0005 & 1.4 & 4 \\
\hline BJ & 0.0008 & 1.4 & 5 \\
\hline BK & 0.0094 & 1.4 & 4 \\
\hline BL & 0.0005 & 1.4 & 4 \\
\hline BM & 0.0006 & 1.4 & 5 \\
\hline BN & 0.0021 & 1.4 & 4 \\
\hline BP & 0.0008 & 1.4 & 4 \\
\hline
\end{tabular}

Note: The actual required minimum number of samples calculated by the one-sample t-test (EPA, 2006; PNNL, 2007) was less than 3 . The minimum number of samples required to calculate statistics is 3 . 
The number of samples needed to meet the criteria stipulated in the CAIP for each sample plot was less than the number collected; therefore, the data are considered representative of the plots and were used to make DQO decisions. Selection of the sample aliquot locations within a sample plot (Sections 4.2.2 and A.9.1 of the CAU 371 CAIP) was accomplished through the use of the VSP software (PNNL, 2007). Each set of sample aliquot locations were derived using the random start, systematic triangular grid pattern for sample placement. Use of the VSP software permitted an unbiased, equal-weighted chance that any given location within the boundaries of the sample plot would be chosen.

\section{Criterion 2:}

All samples were analyzed using the analytical methods listed in Tables 3-2 and 3-3 of the CAU 371 CAIP (NNSA/NSO, 2009) and for the following radiological analytes as listed in Section 3.2 of the CAIP: gamma spectroscopy; Sr-90; and isotopic Am, U, and Pu.

Samples were submitted for all of the analytical methods specified in the analytical program described in Section A.3.2.2 of the CAU 371 CAIP (NNSA/NSO, 2009).

Sample results were assessed against the acceptance criterion for the DQI of sensitivity as defined in the Industrial Sites QAPP (NNSA/NV, 2002). The sensitivity acceptance criterion defined in the CAU 371 CAIP is that analytical detection limits will be less than the corresponding FAL (NNSA/NSO, 2009). All detection limits were less than FALs; therefore, the DQI for sensitivity has been met.

\section{Criterion 3:}

To satisfy the third criterion, the entire dataset, as well as individual sample results, were assessed against the acceptance criteria for the DQIs of precision, accuracy, comparability, completeness, and representativeness, as defined in the Industrial Sites QAPP (NNSA/NV, 2002). The DQI acceptance criteria are presented in Table 6-1 of the CAIP (NNSA/NSO, 2009). As presented in the following subsections, these criteria were met for each of the DQIs. 


\section{$\underline{\text { Precision }}$}

Precision was evaluated as described in Section 6.2.3 of the CAIP (NNSA/NSO, 2009). Table B.1-3 provides the radiological results for all constituents that were qualified for precision.

Table B.1-3

Precision Measurements $^{a}$

\begin{tabular}{|c|c|c|c|c||}
\hline Parameter & Analyses & $\begin{array}{c}\text { Number of } \\
\text { Measurements } \\
\text { Qualified }\end{array}$ & $\begin{array}{c}\text { Number of } \\
\text { Measurements } \\
\text { Performed }\end{array}$ & $\begin{array}{c}\text { Percent } \\
\text { within } \\
\text { Criteria }\end{array}$ \\
\hline \hline Am-241 & Isotopic Americium & 30 & 93 & 68 \\
\hline U-234 & Isotopic Uranium & 35 & 93 & 82 \\
\hline U-235 & Isotopic Uranium & 17 & 93 & 31 \\
\hline Pu-239/240 & Isotopic Plutonium & 64 & 93 & 62 \\
\hline
\end{tabular}

${ }^{\mathrm{a}} \mathrm{SW}-846$ Methods (EPA, 1999 and 2002)

As shown in Table B.1-3, the precision rate for the three isotopes-Am-241, U-234, and Pu-239/240 — did not meet the criteria of 80 percent specified in the CAIP (NNSA/NSO, 2009). The precision evaluations were based on differences in laboratory duplicate sample results (RPD). High variability in the sample matrix suggests that discrete particles of contamination are present within the samples. Therefore, mixing will not produce homogeneity. This variability does not mean the precision of the measurement is poor, but that activities are variable within the samples. This is commonly observed in and Am-241, U-234, and $\mathrm{Pu}-239 / 240$ results because a single particle of these isotopes within a sample can result in detectable activity attributed to the entire sample. Therefore, when a duplicate sample is analyzed for isotopic Am-241, U-234, and Pu-239/240, the results can be significantly different depending on how many discrete particles are contained in each sample.

There is a negligible potential for a false negative DQO decision error because the highest reported activities for Am-241, U-234, and Pu-239/240 that were qualified for precision are still small in comparison to the FALs. The highest Am-241 concentration of $0.51 \mathrm{pCi} / \mathrm{g}$ is approximately 0.006 percent of the 9,239 pCi/g FAL. The highest U-234 concentration of $14.3 \mathrm{pCi} / \mathrm{g}$ is approximately 0.01 percent of the 131,400 pCi/g FAL. The highest reported Pu-239/240 concentration of $6.8 \mathrm{pCi} / \mathrm{g}$ is approximately 0.05 percent of the 12,690 $\mathrm{pCi} / \mathrm{g}$ FAL. Therefore, the Am-241, U-234, and Pu-239/240 results that were qualified for precision can be confidently used to 
support the DQO decision. As the precision rates for all other constituents meet the acceptance criteria for precision, the database is determined to be acceptable for the DQI of precision.

\section{Accuracy}

Accuracy was evaluated as described in Section 6.2.4 of the CAIP (NNSA/NSO, 2009). There were no radiological data qualified for accuracy. Therefore, the CAIP criterion of 80 percent accuracy was met. As the accuracy rates for all contaminants meet the acceptance criterion for accuracy, the dataset is determined to be acceptable for the DQI of accuracy.

\section{$\underline{\text { Representativeness }}$}

The DQO process as identified in Appendix A of the CAU 371 CAIP (NNSA/NSO, 2009) was used to address sampling and analytical requirements for CAU 371. During this process, appropriate locations were selected that enabled the samples collected to be representative of the population parameters identified in the DQO (the most likely locations to contain contamination [judgmental sampling] or that represent contamination of the sample plot [probabilistic sampling] and locations that bound COCs) (Section A.2.1). The sampling locations identified in the Criterion 1 discussion meet this criterion. Therefore, the analytical data acquired during the CAU $371 \mathrm{CAI}$ are considered representative of the population parameters.

\section{Comparability}

Field sampling, as described in the CAU 371 CAIP (NNSA/NSO, 2009), was performed and documented in accordance with approved procedures that are comparable to standard industry practices. Approved analytical methods and procedures per DOE were used to analyze, report, and validate the data. These are comparable to other methods used not only in industry and government practices, but most importantly are comparable to other investigations conducted for the NTS. Therefore, project datasets are considered comparable to other datasets generated using these same standardized DOE procedures, thereby meeting DQO requirements.

Also, standard, approved field and analytical methods ensured that data were appropriate for comparison to the investigation action levels specified in the CAIP. 


\section{Completeness}

The CAU 371 CAIP (NNSA/NSO, 2009) defines acceptable criteria for completeness to be that the dataset is sufficiently complete to be able to make the DQO decisions. This is initially evaluated as 80 percent of CAS-specific analytes identified in the CAU 371 CAIP having valid results. As verified data were provided for all samples and measurements, the datasets, including the TLD measurements of external dose, are considered to meet the DQI criterion for completeness.

Rejected data (either qualified as rejected or data that failed the criterion of sensitivity) are not used in the resolution of DQO decisions and are not counted toward meeting the completeness acceptance criterion. There were no rejected data for the site. Therefore, the criteria of 80 percent completeness was met.

\section{B.1.1.2 DQO Provisions To Limit False Positive Decision Error}

The false positive decision error was controlled by assessing the potential for false positive analytical results. Quality assurance/QC samples such as method blanks were used to determine whether a false positive analytical result may have occurred. No false positive analytical results were detected.

Proper decontamination of sampling equipment also minimized the potential for cross contamination that could lead to a false positive analytical result.

\section{B.1.1.2 Decision II}

As no COCs were detected in surface soils at either CAU 371 CAS, Decision II sampling for surface soil contamination was not considered necessary. However, Decision II was resolved for the subsurface contamination that was assumed to be present at each CAS. To resolve Decision II for the assumed contamination within the fissure at Pin Stripe, it was assumed that the extent of the fissure was encompassed by the crater area and the elevated GWS readings beyond the crater. To resolve Decision II for the assumed contamination from the direct injection of radionuclides resulting from the Johnnie Boy test, it was assumed that the contamination was encompassed by the crater areas plus the area of the ejecta piles at the edge of the crater. 


\section{B.1.1.3 Sampling Design}

The CAIP (NNSA/NSO, 2009) made the following commitments for sampling:

1. Judgmental sampling will be conducted at other releases and at locations of potential contamination identified during the CAI.

Result: Judgmental sampling was conducted at the suspected fissure location at Pin Stripe, at two locations within the ejecta at CAS 18-45-01 where elevated radiological readings were detected, and at two sedimentation areas within a wash downstream from Johnnie Boy GZ to determine whether migration from the site has occurred.

2. Sampling of primary releases will be conducted by a combination of judgmental and probabilistic sampling approaches.

Result: The location of the plots were selected judgmentally and samples were collected within each plot at both Pin Stripe and Johnnie Boy probabilistically as described in Section A.2.0.

\section{B.1.2 Conduct a Preliminary Data Review}

A preliminary data review was conducted by reviewing QA reports and inspecting the data. The contract analytical laboratories generate a QA nonconformance report when data quality does not meet contractual requirements. All data received from the analytical laboratories met contractual requirements, and a QA nonconformance report was not generated. Data were validated and verified to ensure that the measurement systems performed in accordance with the criteria specified. The validated dataset quality was found to be satisfactory.

\section{B.1.3 Select the Test and Identify Key Assumptions}

The test for making DQO decisions for the primary release was the comparison of the TED to the FAL of $25 \mathrm{mrem} / \mathrm{yr}$. For other releases, the test for making DQO Decisions was the comparison of the maximum analyte result from each CAS to the corresponding FAL. All FALs were based on an exposure duration to a site worker using the Remote Work Area exposure scenario.

The key assumptions that could impact a DQO decision are listed in Table B.1-4. 
Table B.1-4

\section{Key Assumptions}

\begin{tabular}{|c|c|}
\hline Exposure Scenario & $\begin{array}{l}\text { The potential for contamination exposure is limited to industrial and construction } \\
\text { workers, and military personnel conducting training. These human receptors may be } \\
\text { exposed to contaminants of potential concern through oral ingestion or inhalation of } \\
\text { soil and/or debris due to inadvertent disturbance of these materials or irradiation by } \\
\text { radioactive materials. }\end{array}$ \\
\hline Affected Media & Surface and shallow subsurface soil, debris such as metal and concrete. \\
\hline $\begin{array}{l}\text { Location of } \\
\text { Contamination/Release } \\
\text { Points }\end{array}$ & Surface soil (to $5 \mathrm{~cm}$ depth). Refer to Section 2.1 . \\
\hline Transport Mechanisms & $\begin{array}{l}\text { Surface water runoff may provide for the transportation of some contaminants } \\
\text { within or outside of the boundaries of the CASs. Percolation of precipitation } \\
\text { through subsurface media serves as a minor driving force for vertical migration } \\
\text { of contaminants. }\end{array}$ \\
\hline Preferential Pathways & Drainages. \\
\hline $\begin{array}{l}\text { Lateral and Vertical } \\
\text { Extent of Contamination }\end{array}$ & $\begin{array}{l}\text { Contamination, if present, is expected to be contiguous to the release points. } \\
\text { Concentrations are expected to decrease with distance and depth from the source. } \\
\text { Groundwater contamination is not expected. Lateral and vertical extent of COC } \\
\text { contamination is assumed to be within the spatial boundaries of each CAS. }\end{array}$ \\
\hline Groundwater Impacts & None. \\
\hline Future Land Use & Reserved Zone. \\
\hline $\begin{array}{l}\text { Other Data Quality } \\
\text { Objective Assumptions }\end{array}$ & $\begin{array}{l}\text { Release at Pin Stripe is due to a venting of radioactive materials from a fissure. } \\
\text { Subsurface contamination is present at Pin Stripe due to the presence of the fissure. } \\
\text { Release at Johnnie Boy is due to atmospheric deposition during testing. Refractory } \\
\text { plutonium is present as discrete particles. Collection of a representative sample can } \\
\text { be impacted by the distribution of the plutonium particles in the sampled soil. }\end{array}$ \\
\hline
\end{tabular}

\section{B.1.4 Verify the Assumptions}

The results of the investigation support the key assumptions identified in the CAU 371 DQOs and

Table B.1-4 except as listed below:

- Exception: At Pin Stripe, it was not anticipated that a dose greater than 25 mrem/yr would be present.

- Impact: No impact to the CSM. Based on sample and radiation survey results, it was determined that the fissure has a significant surface expression. It was conservatively assumed that the fissure contains concentrations of radionuclides in near-surface soils that would cause a dose exceeding the FAL. Therefore, a corrective action was implemented. 
All data collected during the CAI supported CSMs with the exceptions noted in this section. These exceptions did not invalidate the CSMs presented in the CAIP (NNSA/NSO, 2009), nor did they necessitate revisions to the CSMs.

\section{B.1.4.1 Other DQO Commitments}

The CAIP (NNSA/NSO, 2009) made the following commitments for sampling:

1. For Pin Stripe, if the Decision I sample plot results yield a 95 percent UCL of the average TED exceeding the FAL, a Decision II sampling strategy would be presented and agreed upon by the stakeholders before collecting Decision II samples (Section 4.2.2 of the CAU 371 CAIP).

Result: No sample plot surface results exceeded the FAL. However, it was assumed that subsurface contamination in the fissure exceeds the FAL. Decision II was resolved by assuming the extent of contamination was the entire surface expression of the fissure.

2. The minimum three sample plots along each of three vectors at Johnnie Boy would be placed so that the outermost sample plot on each vector would be located beyond the 25-mrem/yr dose boundary (Section 4.2.2 of the CAU 371 CAIP).

Result: The locations of the sample plots met these requirements.

3. If a predetermined location cannot be feasibly sampled, the Site Supervisor will determine an alternate location (Section A.9.1.1 of the CAU 371 CAIP).

Result: The modification of aliquot locations from planned positions was due to field conditions and observations (obstruction from a rock, vegetation, or animal burrows). The distances of the new aliquot locations from the planned locations ranged from approximately 4 in. to approximately 30 in. These changes in the planned locations did not impact the DQO decisions because the samples were collected from the nearest possible location to the original location and are, therefore, still considered to be randomly located.

\section{B.1.5 Draw Conclusions from the Data}

This section resolves the two DQO decisions for each of the CAU 371 CASs.

\section{B.1.5.1 Decision Rules for Decision I}

Decision Rule: If the population parameter of any COPC in the Decision I population of interest exceeds the corresponding FAL, then that COPC is identified as a COC, and Decision II samples will be collected, else no further investigation is needed for that release in that population. 
Result: Although no COCs were identified at either CAS at sample plots, COCs were assumed to be present at both CASs in subsurface soils based on process knowledge. Therefore, Decision II was resolved at both CASs.

Decision Rule: If COC contamination is inconsistent with the CSM or extends beyond the spatial boundaries identified in Section A.6.2 of the CAU 371 CAIP (NNSA/NSO, 2009), then work will be suspended and the investigation strategy will be reconsidered, else the decision will be to continue sampling to define the extent.

Result: The COC contamination was not found to be inconsistent with the CSM or extend beyond the spatial boundaries; therefore work was not suspended.

Decision Rule: If a COC exists at any CAS, then a corrective action will be determined, else no further action will be necessary.

Result: Because COCs were identified for both CASs, corrective actions are required.

Decision Rule: If a waste is present that, if released, has the potential to cause the future contamination of site environmental media, then a corrective action will be identified, else no further action will be necessary.

Result: For both CASs, no wastes were identified.

\section{B.1.5.2 Decision Rules for Decision II}

Decision Rule: If COC contamination is inconsistent with the CSM or extends beyond the spatial boundaries identified in Section A.6.2 of the CAU 371 CAIP (NNSA/NSO, 2009), then work will be suspended and the investigation strategy will be reconsidered, else the decision will be to continue sampling to define the extent.

Result: The COC contamination was not found to be inconsistent with the CSM or extend beyond the spatial boundaries; therefore there was no need to suspend work.

Decision Rule: If the population parameter (the observed concentration of any COC) in the Decision II population of interest exceeds the corresponding FAL in any bounding direction, or 
potential remediation waste types have not been adequately defined, then additional samples will be collected to complete the Decision II evaluation, else the extent of the COC contamination has been defined.

Result: Decision II samples were not collected and subsurface COCs were assumed to be limited to the fissure at Pin Stripe and the crater at Johnnie Boy.

Decision Rule: If a radiation survey isopleth exists that bounds all locations determined to exceed the 95 percent UCL of the 25-mrem/yr TED, then the isopleth will be established as the corrective action boundary, else the radiation survey area will be increased until that boundary is defined.

Result: No investigation results exceeded FALs. Therefore, Decision II samples were collected. Subsurface COCs were assumed to be limited to the fissure at Pin Stripe and the crater at Johnnie Boy. 


\section{B.2.0 References}

BN, see Bechtel Nevada.

Bechtel Nevada. 1999. An Aerial Radiological Survey of the Nevada Test Site, DOE/11718--324. Prepared for U.S. Department of Energy, Nevada Operations Office. Las Vegas, NV: Remote Sensing Laboratory.

EPA, see U.S. Environmental Protection Agency.

NNSA/NSO, see U.S. Department of Energy, National Nuclear Security Administration Nevada Site Office.

NNSA/NV, see U.S. Department of Energy, National Nuclear Security Administration Nevada Operations Office.

PNNL, see Pacific Northwest National Laboratory.

Pacific Northwest National Laboratory. 2007. Visual Sample Plan, Version 5.0 User's Guide, PNNL-16939. Richland, WA.

U.S. Department of Energy, National Nuclear Security Administration Nevada Operations Office. 2002. Industrial Sites Quality Assurance Project Plan, Nevada Test Site, Nevada, Rev. 3, DOE/NV--372. Las Vegas, NV.

U.S. Department of Energy, National Nuclear Security Administration Nevada Site Office. 2009. Corrective Action Investigation Plan for Corrective Action Unit 371: Johnnie Boy Crater and Pin Stripe, Nevada Test Site, Nevada, Rev. 0, DOE/NV--1310. Las Vegas, NV.

U.S. Environmental Protection Agency. 2006. Data Quality Assessment: Statistical Methods for Practitioners, EPA QA/G-9S, EPA/240/B-06/003. Washington, DC: Office of Environmental Information. 


\section{Appendix C}

\section{Risk Assessment}


The risk-based corrective action (RBCA) process used to establish FALs is described in the Industrial Sites Project Establishment of Final Action Levels (NNSA/NSO, 2006). This process conforms with NAC Section 445A.227, which lists the requirements for sites with soil contamination (NAC, 2008a). For the evaluation of corrective actions, NAC Section 445A.22705 (NAC, 2008b) requires the use of ASTM Method E1739 (ASTM, 1995) to "conduct an evaluation of the site, based on the risk it poses to human health and the environment, to determine the necessary remediation standards (i.e., FALs) or to establish that corrective action is not necessary."

This process defines three tiers (or levels) of evaluation involving increasingly sophisticated analyses:

- Tier 1 evaluation - Sample results from source areas (highest concentrations) are compared to action levels based on generic (non-site-specific) conditions (i.e., the PALs established in the CAU 371 CAIP [NNSA/NSO, 2009]). The FALs may then be established as the Tier 1 action levels, or the FALs may be calculated using a Tier 2 evaluation.

- Tier 2 evaluation - Conducted by calculating Tier 2 Site-Specific Target Levels (SSTLs) using site-specific information as inputs to the same or similar methodology used to calculate Tier 1 action levels. The Tier 2 SSTLs are then compared to individual sample results from reasonable points of exposure (as opposed to the source areas as is done in Tier 1) on a point-by-point basis. Total concentrations of total petroleum hydrocarbons will not be used for risk-based decisions under Tier 2 or Tier 3. Rather, the individual chemicals of concern will be compared to the SSTLs.

- Tier 3 evaluation - Conducted by calculating Tier 3 SSTLs on the basis of more sophisticated risk analyses using methodologies described in Method E1739 that consider site-, pathway-, and receptor-specific parameters.

The risk-based corrective action decision process stipulated in the Industrial Sites Project Establishment of Final Action Levels (NNSA/NSO, 2006) is summarized in Figure C.1-1. 


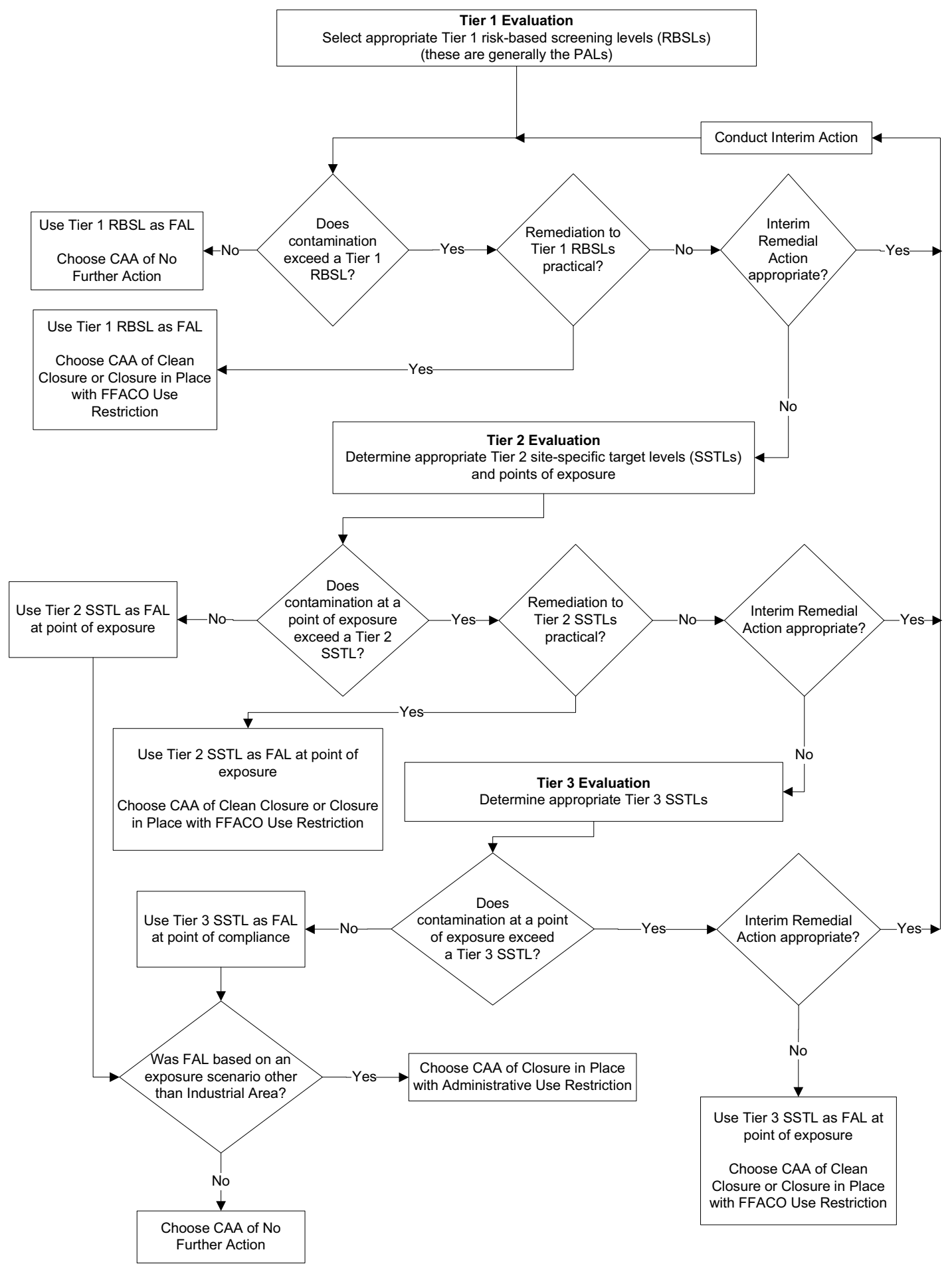

(ASTM, 1995)

Figure C.1-1

Risk-Based Corrective Action Decision Process 


\section{C.1.1 A. Scenario}

Page $\mathrm{C}-3$ of $\mathrm{C}-13$

Corrective Action Unit 371, Johnnie Boy Crater and Pin Stripe, comprises the following two CASs within Areas 11 and 18 of the NTS:

- 11-23-05, Pin Stripe Contamination Area

- 18-45-01, U-18j-2 Crater (Johnnie Boy)

Corrective Action Site 11-23-05, Pin Stripe Contamination Area (referred to as Pin Stripe in this document), is an inactive site located in Area 11, north of the Area 5 RWMS. Pin Stripe consists of a release of radioactive material to the soil surface as a result of the venting of radiological material from a fissure during the Pin Stripe (U11b) weapons-effects test. The Pin Stripe test was conducted on April 25, 1966, at a depth of $296 \mathrm{~m}$ bgs (DOE/NV, 1996b and 2000). Venting occurred from a fissure approximately 30 to $46 \mathrm{~m}$ southwest of GZ. A subsidence crater measuring $67 \mathrm{~m}$ in diameter and $4.6 \mathrm{~m}$ deep resulted from this test (Sandia, 1966).

Corrective Action Site 18-45-01, U-18j-2 Crater (Johnnie Boy) (referred to as Johnnie Boy in this document), is an inactive site located in Area 18 of the NTS, approximately $500 \mathrm{~m}$ south of the 18-03 Road. Johnnie Boy consists of a release of radioactive material to the soil surface from the Johnnie Boy (U-18j-2) weapons-effects test. The Johnnie Boy test was conducted on July 11, 1962 , at a depth of $58.4 \mathrm{~cm}$ (DOE/NV, 2000). A surface crater measuring $34 \mathrm{~m}$ in diameter at its widest point and $9 \mathrm{~m}$ deep resulted from this test (GE, 1979).

\section{C.1.2 B. Site Assessment}

The Pin Stripe site includes the area affected by the surface release of radioactivity associated with unintentional venting from the subsurface Pin Stripe nuclear test. A subsidence crater is present at the site. Scattered testing related debris is present throughout the area. No removable contamination was identified on the debris. Staged TLDs and soil samples collected at various locations within this CAS were used to calculate TED to workers. Refer to Section A.3.2.3 for details on the calculation of the TED. No TEDs from surface soil plots at Pin Stripe exceeded the Remote Work Area Scenario based FAL established in this appendix (25 mrem/RW-yr). This scenario was conservatively used as it is more protective than the actual current and projected site use. The maximum calculated TED (based on the Remote Work Area Scenario) was 9.1 mrem/yr. However, it was shown that if site use 
were to change in the future to a continuous industrial work site, an industrial worker could potentially receive a TED in excess of $25 \mathrm{mrem} / \mathrm{yr}$. The maximum calculated TED (based on the Industrial Area Scenario) was $60.9 \mathrm{mrem} / \mathrm{yr}$. However, subsurface contamination is assumed to be present in the Pin Stripe fissure that exceeds FALs.

The Johnnie Boy site includes the area affected by the surface release of radioactivity associated with the Johnnie Boy nuclear test. A blowout crater is present at the site surrounded by mounds of ejected soil. Test-related debris is present throughout the area, and the area is posted as a radioactive materials area. Staged TLDs and soil samples collected at various locations within this CAS were used to calculate TED to site workers. Refer to Section A.4.2.3 for details on the calculation of the TED. No TEDs from surface soil plots at Johnnie Boy exceeded the Remote Work Area Scenario based FAL established in this appendix (25 mrem/RW-yr). This scenario was conservatively used as it is more protective than the actual current and projected site use. The maximum calculated TED (based on the Remote Work Area Scenario) was $8.5 \mathrm{mrem} / \mathrm{yr}$. However, it was shown that if site use were to change in the future to a continuous industrial work site, an industrial worker could potentially receive a TED in excess of $25 \mathrm{mrem} / \mathrm{yr}$. The maximum calculated TED (based on the Industrial Area Scenario) was $56.8 \mathrm{mrem} / \mathrm{yr}$. However, subsurface contamination is assumed to be present in the Johnnie Boy crater and ejecta piles that exceeds FALs.

\section{C.1.3 C. Site Classification and Initial Response Action}

The four major site classifications listed in Table 3 of the ASTM Standard are (1) immediate threat to human health, safety, and the environment; (2) short-term (0 to 2 years) threat to human health, safety, and the environment; (3) long-term (greater than 2 years) threat to human health, safety, or the environment; and (4) no demonstrated long-term threats.

Based on the CAI, Pin Stripe and Johnnie Boy do not present an immediate threat to human health, safety, and the environment; therefore, no interim response actions are necessary at these sites. However, corrective actions are required at both sites due to the presence of potential subsurface contamination exceeding the $25 \mathrm{mrem} / \mathrm{RW}$-yr FAL. At both CASs, contamination is present that could pose a short-term threat to human health, safety, or the environment if any excavation was done in the crater or fissure. Thus, both CASs have been determined to be Classification 2 sites as defined by ASTM Method E1739. 


\section{C.1.4 D. Development of Tier 1 Lookup Table of RBSLs}

Tier 1 risk-based screening levels (RBSLs) are defined as the PALs listed in the CAIP (NNSA/NSO, 2009) as established during the DQO process. For the primary release, the PAL for radionuclides was established as $25 \mathrm{mrem} / \mathrm{yr}$ of TED based on the Industrial Area exposure scenario. For other releases, the PALs for radionuclides are individual radionuclide activities as defined in the CAIP. This represents a very conservative estimate of risk, is preliminary in nature, and is used for site screening purposes. Although the PAL was not intended to be used as a FAL, a FAL may be defined as the Tier 1 RBSL (i.e., PAL) value if implementing a corrective action based on the Tier 1 RBSL would be appropriate.

The Industrial Area scenario assumes that a full-time industrial worker is present at a particular location for his entire career (225 day/yr, $10 \mathrm{hr} /$ day for a duration of 25 years). The 25-mrem/yr dose-based PAL for radionuclides based on the Industrial Area exposure scenario is implemented by calculating dose a site worker would receive if exposed to the site contaminants over a yearly exposure period of 2,250 hours.

\section{C.1.5 E. Exposure Pathway Evaluation}

For both CASs, the DQOs stated that site workers would only be exposed to COCs through oral ingestion, inhalation, or dermal contact (absorption) of soil or debris due to inadvertent disturbance of these materials or irradiation by radioactive materials at the CASs. The potential exposure pathways would be through worker contact with the contaminated soil or various debris currently present within the site boundary. The limited migration demonstrated by the analytical results, elapsed time since the suspected release, and depth to groundwater supports the selection and evaluation of only surface and shallow subsurface contact as the complete exposure pathways. Ingestion of groundwater is not considered to be a significant exposure pathway.

\section{C.1.6 F. Comparison of Site Conditions with Tier 1 RBSLS}

For the primary release at both Pin Stripe and Johnnie Boy, the Industrial Area exposure time of 2,250 hr/yr was used to calculate site radiological doses (TED). These values were compared to the Tier 1 RBSL (25-mrem/IA-yr dose). For other releases, soil sample analytical results were directly compared to the Tier 1 RBSL activities. 
All Industrial Area scenario based TED results for the primary release and all analytical results for the other release samples were less than Tier 1 RBSLs (i.e., PALs) except for those listed in Table C.1-1.

Table C.1-1

Locations Where TED Exceeds the PAL at CAU 371 (mrem/IA-yr)

\begin{tabular}{||c|c|c|c||}
\hline CAS & Plot & Average TED & 95\% UCL TED \\
\hline \hline \multirow{3}{*}{$\begin{array}{c}\text { 11-23-05 } \\
\text { (Pin Stripe) }\end{array}$} & AA & 60.9 & 71.6 \\
\cline { 2 - 4 } & AB & 35.9 & 45.8 \\
\cline { 2 - 4 } & AC & 23.0 & 30.6 \\
\hline \multirow{4}{*}{$\begin{array}{c}18-45-01 \\
\text { (Johnnie Boy) }\end{array}$} & BA & 44.4 & 49.9 \\
\cline { 2 - 4 } & BB & 30.6 & 38.0 \\
\cline { 2 - 4 } & BC & 33.2 & 37.8 \\
\cline { 2 - 4 } & BD & 23.1 & 29.0 \\
\cline { 2 - 4 } & BJ & 50.8 & 62.9 \\
\cline { 2 - 4 } & BK & 56.8 & 63.1 \\
\cline { 2 - 4 } & BN & 35.8 & 45.1 \\
\hline
\end{tabular}

Bold indicates the values exceeding $25 \mathrm{mrem} / \mathrm{yr}$.

\section{C.1.7 G. Evaluation of Tier 1 Results}

For the locations listed in Table C.1-1, the TED exceeded the Tier 1 RBSL. It was determined by NNSA/NSO that remediation to the RBSL is not appropriate based on risk to receptors. The risk to receptors from contaminants at CAU 371 is due to chronic exposure to radionuclides (i.e., receiving a dose over time). Therefore, the risk to a receptor is directly related to the amount of time a receptor is exposed to the contaminants. A review of the current and projected use of both sites determined that workers may only be present at these sites for a few hours per year (see Section C.1.10), and it is not reasonable to assume that any worker would be present at this site for 2,250 hr/yr (DOE/NV, 1996a). Therefore, it was determined to conduct a Tier 2 evaluation.

\section{C.1.8 H. Tier 1 Remedial Action Evaluation}

No remedial actions are proposed based on Tier 1 RBSLs. 


\section{C.1.9 I. Tier 2 Evaluation}

No additional data were needed to complete a Tier 2 evaluation.

\section{C.1.10 J. Development of Tier 2 Table of SSTLS}

The Tier 2 action levels are typically compared to contaminant values that are representative of areas at which an individual or population may come in contact with a COC originating from a CAS. This concept is illustrated in the EPA's Human Health Evaluation Manual (EPA, 1989). This document states that "the area over which the activity is expected to occur should be considered when averaging the monitoring data for a hot spot. For example, averaging soil data over an area the size of a residential backyard (e.g., an eighth of an acre) may be most appropriate for evaluating residential soil pathways.” When evaluating industrial receptors, the area over which an industrial worker is exposed may be much larger than for residential receptors. For a site that is limited to industrial uses, the receptor would be a site worker, and patterns of employee activity would be used to estimate the area over which the receptor is exposed. This can be very complicated to calculate, as industrial workers may perform routine activities at many locations where only a portion of these locations may be contaminated. A more practical measure of integrated risk to radiological dose for an industrial worker is to calculate the portion of total work time that the worker is in proximity to elevated radioactivity — and, therefore, able to receive a dose. For example, a site worker may have routine activities that require him or her to be exposed to a radioactive location for 225 hours out of each year. If the worker's industrial work schedule was $10 \mathrm{hr} / \mathrm{day}$ for 225 day/yr — or 2,250 hr/yr (as is used for the Industrial Area exposure scenario) — the site worker would receive 10 percent of the potential annual dose that he or she would otherwise receive if exposed to the radioactive location for the entire work year.

For the development of radiological Tier 2 SSTLs, the annual dose limit for a site worker is $25 \mathrm{mrem} / \mathrm{yr}$ (the same as was used for the Tier 1 evaluation). The Tier 2 evaluation is based on a receptor exposure time that is more specific to actual site conditions. A review of the current and projected use of both sites determined that workers may be present at these sites only for a few hours per year and it is not reasonable to assume that any worker would be present at this site for 2,250 hr/yr (a full-time basis) (DOE/NV, 1996a). In the CAU 371 DQOs, it was conservatively determined that the Occasional Use Area exposure scenario (as listed in Section 3.1.1 of the CAU 371 CAIP 
[NNSA/NSO, 2009]) would be used in calculating receptor exposure time. This exposure scenario assumes workers may use the site occasionally for intermittent or short-term activities and be exposed to site contaminants for $80 \mathrm{hr} / \mathrm{yr}$ (i.e., equivalent to $8 \mathrm{hr} /$ day, 10 day/yr, for 5 years).

\section{C.1.11 K. Comparison of Site Conditions with Tier 2 Table SSTLS}

Using the maximum dose measured at any location outside the Pin Stripe fissure, a receptor would have to be exposed to the location of maximum surface dose for 922 hours to receive a dose of 25 mrem. Similarly, based on the maximum dose measured outside the crater area at Johnnie Boy, a receptor would have to be exposed to the location of maximum surface dose for 990 hours to receive a dose of $25 \mathrm{mrem}$. Although the time required for a 25-mrem/yr dose at both CASs (more than $900 \mathrm{hr} / \mathrm{yr}$ ) is greater than either the Occasional Use Area exposure time ( $80 \mathrm{hr} / \mathrm{yr})$ or the Remote Work Area exposure time (336 hr/yr), it was decided to base the Tier 2 SSTLs on the Remote Work Area exposure scenario. Using this Tier 2 SSTL as the FAL, corrective actions would not be required as long as receptors are not exposed to site radioactivity for more than $336 \mathrm{hr} / \mathrm{yr}$. Any site activity that would not require a receptor to be exposed to contaminants outside the corrective action boundary for more than $336 \mathrm{hr} / \mathrm{yr}$ could not result in a dose above $25 \mathrm{mrem}$ and would not need to be restricted. This would include activities such as road maintenance, military exercises, maintenance of postings, etc.

Implementation of the 25-mrem/yr dose-based Tier 2 SSTL for radionuclides based on the Remote Work Area exposure scenario was accomplished by calculating dose (i.e., TED) at the site over an exposure period of 336 hours ( $8 \mathrm{hr} /$ day, 42 day/yr). The TEDs calculated using the Remote Work Area exposure scenario were then compared to the 25-mrem/RW-yr Tier 2 SSTL. As shown in Table C.1-2, all of the Remote Work Area exposure scenario TED values from the sample plots of both CAU 371 CASs were less than the 25-mrem/RW-yr Tier 2 SSTL. Therefore, no corrective actions will be required for surface contamination at either CAS.

Based on the assumption of subsurface contamination in the fissure at Pin Stripe and in the crater at Johnnie Boy, these areas are also assumed to exceed an SSTL based on any exposure scenario. Therefore, these areas will require corrective action. 
Table C.1-2

Remote Work Area Scenario TED (mrem/RW-yr)

\begin{tabular}{|c|c|c|c|}
\hline CAS & Plot/Location & Average TED & 95\% UCL TED \\
\hline \multirow{6}{*}{$\begin{array}{c}\text { 11-23-05 } \\
\text { (Pin Stripe) }\end{array}$} & AA & 9.1 & 10.7 \\
\hline & $A B$ & 5.4 & 6.8 \\
\hline & $A C$ & 3.4 & 4.6 \\
\hline & $A D$ & 0.7 & 1.7 \\
\hline & $\mathrm{AE}$ & 0.8 & 1.9 \\
\hline & AF & 1.3 & 2.5 \\
\hline \multirow{21}{*}{$\begin{array}{c}\text { 18-45-01 } \\
\text { (Johnnie Boy) }\end{array}$} & BA & 6.6 & 7.4 \\
\hline & BB & 4.6 & 5.7 \\
\hline & $\mathrm{BC}$ & 5.0 & 5.6 \\
\hline & $\mathrm{BD}$ & 3.5 & 4.3 \\
\hline & BE & 7.6 & 9.4 \\
\hline & $\mathrm{BF}$ & 2.7 & 3.5 \\
\hline & $B G$ & 1.5 & 2.3 \\
\hline & $\mathrm{BH}$ & 0.2 & 0.5 \\
\hline & BJ & 8.5 & 9.4 \\
\hline & BK & 5.3 & 6.7 \\
\hline & $\mathrm{BL}$ & 1.8 & 2.2 \\
\hline & BM & 0.3 & 0.8 \\
\hline & $\mathrm{BN}$ & 8.3 & 10.0 \\
\hline & $\mathrm{BP}$ & 2.1 & 2.8 \\
\hline & $\mathrm{BQ}$ & 2.3 & 3.1 \\
\hline & BR & 2.2 & 2.9 \\
\hline & BS & 2.2 & 2.7 \\
\hline & BT & 0.6 & 1.1 \\
\hline & $\mathrm{BU}$ & 0.6 & 1.4 \\
\hline & BV & 0.006 & 0.81 \\
\hline & $\mathrm{BZ}$ & 2.1 & 2.8 \\
\hline
\end{tabular}




\section{C.1.12 L. Tier 2 Remedial Action Evaluation}

Based on the Tier 2 evaluation, the surface soils at Pin Stripe and Johnnie Boy do not pose an unacceptable risk to human health and the environment. Therefore, no further corrective action is necessary for the radiological contamination of surface soil at these sites. However, it is assumed that subsurface contamination exists at Pin Stripe due to the presence of higher levels of contamination within the fissure and at Johnnie Boy due to the direct injection of radioactivity into the Johnnie Boy crater from the nuclear test. It is also assumed that this subsurface contamination exceeds the Tier 2 SSTL of $25 \mathrm{mrem} / \mathrm{RW}$-yr. A corrective action is practical for the subsurface contamination at these CASs; therefore, the Tier 2 SSTL is established as the FAL, and a corrective action will be proposed.

As the radiological FAL was established as the Tier 2 SSTL, a Tier 3 evaluation was not necessary. 


\section{C.2.0 Recommendations}

Because all of the TED values for surface soils at both CAU 371 CASs were less than the corresponding FALs at all locations (using the Remote Work Area exposure scenario), it was determined that surface soil contamination at these locations do not warrant corrective actions. However, subsurface contamination exists at Pin Stripe and Johnnie Boy that is assumed to exceed the Remote Work Area exposure scenario based FAL or 25 mrem/RW-yr. Therefore, a corrective action is necessary for the subsurface contamination at both CAU 371 CASs.

The FAL was based on an exposure time of $336 \mathrm{hr} / \mathrm{yr}$ of site worker exposure to CAS surface soils. To prevent future industrial land use activities conducted at the site that may cause a full-time industrial site worker to be exposed to site contamination for 2,250 hr/yr (and, therefore, have the potential to receive a dose exceeding $25 \mathrm{mrem} / \mathrm{yr}$ ), an administrative UR was implemented at Johnnie Boy as a BMP. The area at Johnnie Boy that provides sufficient dose to potentially cause a full-time industrial worker to receive an annual dose exceeding 25 mrem was conservatively defined in Section D.1.2.

The locations at Pin Stripe that provide sufficient dose to potentially cause a full-time industrial worker to receive an annual dose exceeding 25 mrem were located inside the FFACO UR implemented for the subsurface contamination associated with the crater and fissure. Therefore, an additional administrative UR for this CAS was not necessary.

The corrective actions for CAU 371 are based on the assumption that activities on the NTS will be limited to those that are industrial in nature and that the NTS will maintain controlled access (i.e., restrict public access and residential use). Should the future land use of the NTS change such that these assumptions no longer are valid, additional evaluation may be necessary.

The FFACO URs for both CASs and the administrative UR for Johnnie Boy are recorded in the FFACO database, NNSA/NSO Facility Information Management System, and the NNSA/NSO CAU/CAS files. These URs are included in Appendix D. 


\section{C.3.0 References}

ASTM, see American Society for Testing and Materials.

American Society for Testing and Materials. 1995 (reapproved 2002). Standard Guide for Risk-Based Corrective Action Applied at Petroleum Release Sites, ASTM E1739 - 95(2002). Philadelphia, PA.

EPA, see U.S. Environmental Protection Agency.

GE, see General Electric Company-TEMPO.

General Electric Company-TEMPO. 1979. Compilation of Local Fallout Data from Test Detonations 1945-1962 Extracted from DASA 1251, Volume I, DNA 1251-1-EX. 1 May. Prepared for Defense Nuclear Agency. Santa Barbara, CA: DASIAC.

NAC, see Nevada Administrative Code

NNSA/NSO, see U.S. Department of Energy, National Nuclear Security Administration Nevada Site Office.

NNSA/NV, see U.S. Department of Energy, National Nuclear Security Administration Nevada Operations Office.

Nevada Administrative Code. 2008a. NAC 445A.227, “Contamination of Soil: Order by Director for Corrective Action; Factors To Be Considered in Determining Whether Corrective Action Required.” Carson City, NV. As accessed at http://www.leg.state.nv.us/nac on 7 April 2010.

Nevada Administrative Code. 2008b. NAC 445A.22705, “Contamination of Soil: Evaluation of Site by Owner or Operator; Review of Evaluation by Division.” Carson City, NV. As accessed at http://www.leg.state.nv.us/nac on 7 April 2010.

Sandia, see Sandia Corporation.

Sandia Corporation. 1966. Letter to W.W. Allaire (U.S. Atomic Energy Commission) entitled, “Scientific Advisor’s Report of Pin Stripe,” 19 May. Open Net Accession Number 77515. Sandia Base, Albuquerque, NM.

U.S. Department of Energy, National Nuclear Security Administration Nevada Site Office. 2006. Industrial Sites Project Establishment of Final Action Levels, Rev. 0, DOE/NV--1107. Las Vegas, NV. 
U.S. Department of Energy, National Nuclear Security Administration Nevada Site Office. 2009. Corrective Action Investigation Plan for Corrective Action Unit 371: Johnnie Boy Crater and Pin Stripe, Nevada Test Site, Nevada, Rev. 0, DOE/NV--1010. Las Vegas, NV.

U.S. Department of Energy, Nevada Operations Office. 1996a. Final Environmental Impact Statement for the Nevada Test Site and Off-Site Locations in the State of Nevada, DOE/EIS-0243. Las Vegas, NV.

U.S. Department of Energy, Nevada Operations Office. 1996b. Radiological Effluents Released From U.S. Continental Tests 1961 Through 1992, DOE/NV-317 (Rev 1) UC-702. August. Las Vegas, NV.

U.S. Department of Energy, Nevada Operations Office. 2000. United States Nuclear Tests, July 1945 through September 1992, DOE/NV--209-Rev 15. Las Vegas, NV.

U.S. Environmental Protection Agency. 1989. Risk Assessment Guidance for Superfund, Volume I, Human Health Evaluation Manual (Part A), EPA/540/1-89/002. Washington, DC: Office of Emergency and Remedial Response. 


\section{Attachment C-1}

Derivation of Residual Radioactive Material Guidelines for Radionuclides in Soil at Corrective Action Unit (CAU) 371 Johnnie Boy Crater and Pin Stripe Nevada Test Site, Nevada

(8 Pages) 
Derivation of Residual Radioactive Material Guidelines for Radionuclides in Soil at Corrective Action Unit (CAU) 371, Johnnie Boy Crater and Pin Stripe, Nevada Test Site, Nevada

April 2010

Prepared by:

Navarro Nevada Environmental Services

232 Energy Way, North Las Vegas, Nevada 89030

Work sponsored by United States Department of Energy, National Nuclear Security Administration Nevada Site Office, Environmental Restoration Division,

Las Vegas, Nevada 


\subsection{Introduction}

The U.S. Department of Energy (DOE), National Nuclear Security Administration Nevada Site Office (NNSA/NSO) Environmental Restoration Division has numerous sites impacted from the development, testing, and production of nuclear weapons. These impacts can take the form of chemical and/or radiological contaminants. The NNSA/NSO is committed to properly evaluating, radiologically characterizing, and where appropriate, managing these sites to ensure the potential radiation doses to radiation workers and members of the public are below the basic dose limits as stated in DOE Order 5400.5 (DOE, 1993), and are "as low as is reasonably achievable" (ALARA). To provide a margin of safety and to ensure that ALARA is practiced, the basic dose limit in the order is lowered to provide a performance goal, referred to as a "dose constraint."

The general technical approach to evaluating the potential radiation dose from residual radioactive material in surface soils can be described in three basic steps.

First, the effective dose ([ED] or "external dose") is determined via thermoluminescent dosimeters (TLDs) that are placed at soil sampling locations over a time period that is roughly equal to the selected exposure scenario.

Next, the committed effective dose ([CED] or "internal dose") at soil sampling locations is estimated by collecting surface soil samples and comparing the results directly to residual radioactive material guidelines (RRMGs). The RRMG is the concentration of each radionuclide contaminant of concern, in units of picocuries per gram $(\mathrm{pCi} / \mathrm{g})$ that would provide a potential internal dose of 25 millirem per year ( $\mathrm{mrem} / \mathrm{yr}$ ) under the selected exposure scenario. Three primary exposure scenarios are described in NNSA/NSO (2006).

Finally, the total effective dose (TED) for each soil sampling location is determined by summing the ED and the CED (adding the external dose to the internal dose). The TED is then directly compared to the dose constraint to make a decision about each sampled location.

The selected exposure scenario for Corrective Action Unit (CAU) 371, its modifications, and the modeling that was performed to determine the RRMGs is the primary subject of this attachment. 


\subsection{Exposure Scenario}

Exposure scenarios are patterns of human activity that can affect the release of radioactivity from a contaminated zone, and the amount of exposure received at the exposure location. Exposure scenarios describe reasonable potential future uses of the land areas that are being evaluated. Assumptions made in the exposure scenario are key inputs into the modeling that is performed to derive RRMGs.

Three exposure scenarios for use at the Nevada Test Site (NTS) are detailed in the document Industrial Sites Project Establishment of Final Action Levels (NNSA/NSO, 2006). The Industrial Area exposure scenario was selected as the default or baseline scenario for CAU 371, and it is the most conservative or most limiting of the three available scenarios.

The Industrial Sites Project Establishment of Final Action Levels (NNSA/NSO, 2006) promulgates many factors that are to be used as input parameters to dose models. For the soils project work at the NTS, the Residual Radioactive (RESRAD) computer code, version 6.4 (Yu et al., 2001), dose assessment model has been selected. In the Industrial Sites Project Establishment of Final Action Levels document, two input parameters are not specified so that site specific values can be used. Note also that all other input parameters can be modified to more site-specific values if a Tier 3 evaluation is warranted and necessary.

The Industrial Access exposure scenario was used in the derivation of RRMGs for CAU 371.

Of the two non-specified input parameters, the first ("area of the contaminated zone") was set to 1,000 square meters $\left(\mathrm{m}^{2}\right)$. This value was selected as a compromise between DOE Order 5400.5 (DOE, 1993) (which specifies that "residual concentrations of radioactive material in soil are defined as those in excess of background concentrations averaged over an area of $100 \mathrm{~m}^{2 \prime}$ ), and the likely area that would be occupied under the Industrial Access exposure scenario, which is several thousand $\mathrm{m}^{2}$. In order to satisfy both considerations, soil samples are collected and radiation dose is evaluated over areas of $100 \mathrm{~m}^{2}$, but RRMGs are calculated over an area of $1,000 \mathrm{~m}^{2}$. The use of a larger area in the derivation of the RRMGs adds realism to the approach because a larger area of contamination will generally yield a larger dose estimate.

The second non-specified input parameter ("thickness of the contaminated zone") was set to 0.05 meters $(\mathrm{m})$. This depth encompasses the bulk of the potential contamination at NTS and includes the maximum concentration.

Finally, it is important to note that one of the more significant assumptions in any of the three exposure scenarios is the "exposure frequency," which is established in the Industrial Area scenario as 10 hours per day for 225 days. The exposure frequency varies significantly between the three established scenarios. 


\subsection{RESRAD Calculations}

\subsection{Guidance for RESRAD Calculations}

The guidance in this section was developed by NNSA/NSO and the Nevada Division of Environmental Protection (NDEP) and is only applicable to soils containing residual radioactive material. This guidance does not apply to structures, facilities, equipment, and building materials containing contaminated surfaces or volume contamination. The primary dose limit for any member of the public is 100-millirem (mrem) TED in a year. This limit applies to the sum of internal and external doses resulting from all modes of exposure to all radiation sources other than background radiation and doses received as a patient from medical sources as required by DOE 5400.5, II.1.a.(3)(a) (DOE, 1993). The dose constraint is defined as one quarter of the dose limit (i.e., $25 \mathrm{mrem} / \mathrm{yr}$ ) and will be applied to ensure that, in a 1,000-year period, the maximally exposed individual does not exceed the dose constraint in any single year.

Background radiation refers to the local area and is defined as:

- Concentrations of naturally occurring radionuclides.

- Cosmic radiation.

- Radionuclides of anthropogenic origin that have been globally dispersed and are present at low concentrations, such as fallout from nuclear weapons. (Note: Due to the nature of the historical mission at the NTS, this portion of the definition is not applicable to soils project work at the NTS)

Due to the impracticality of determining and validating a "true" background dataset at the NTS, RRMGs will be derived and applied without a subtraction of background. The use of RRMGs with no background subtraction is a conservative approach as it will slightly overestimate the internal dose due to nuclear testing activities at the NTS.

\subsection{RESRAD Software}

The RESRAD computer code, version 6.4 (Yu et al., 2001), was used to derive the RRMGs.

\subsection{Dose Conversion Factors}

International Council on Radiological Protection 72 dose conversion factors were used to derive the RRMGs.

\subsection{Nomenclature}

Because RRMGs are scenario-specific, the RRMGs that are developed for the Industrial Area scenario will be denoted as "RRMG $\mathrm{IIA}_{\mathrm{I}}$ " 


\subsection{Calculation of Residual Radioactive Material Guidelines}

The RRMGs for the Industrial Area exposure scenario $\left(\mathrm{RRMG}_{\mathrm{IA}}\right)$ were derived using the RESRAD computer code, version 6.4 (Yu et al., 2001). The goal of this effort was to produce guidelines for soil sample results, in units of $\mathrm{pCi} / \mathrm{g}$ that would result in a committed effective dose (CED or "internal dose") that would be equal to the dose constraint of $25 \mathrm{mrem}$.

In the site evaluation approach that was used at CAU 371, the dose constraint is also the final action level (FAL).

The key RESRAD parameters used in the derivation of $\mathrm{RRMG}_{\mathrm{IA}}$ values are presented in Table 3-1. The derived values of the $\mathrm{RRMG}_{\mathrm{IA}}$ are presented in Table 3-2.

Table 3-1

\begin{tabular}{|c|c|c|}
\hline \\
\hline RESRAD Parameter & Assigned Value & Explanation \\
\hline Area of $\mathrm{CZ}\left(\mathrm{m}^{2}\right)$ & 1,000 & $\begin{array}{l}\text { Appendix B states "Site Specific." Previously, } 100 \mathrm{~m}^{2} \text { was selected to } \\
\text { conform to the maximum area of contamination limitation in DOE } \\
\text { Order } 5400.5 \text {. Going forward, } 1,000 \mathrm{~m}^{2} \text { has been selected to add } \\
\text { conservativism and realism to the RRMGs. The } 1,000 \mathrm{~m}^{2} \text { RRMGs will } \\
\text { be applied to } 100 \mathrm{~m}^{2} \text { evaluation areas. }\end{array}$ \\
\hline Thickness of CZ (m) & 0.05 & $\begin{array}{l}\text { Appendix B states "Site Specific." This depth encompasses the bulk of } \\
\text { the potential contamination and includes the maximum concentration. }\end{array}$ \\
\hline Cover Depth & 0.00 & $\begin{array}{l}\text { Appendix B states "Site Specific." Cover depth only affects the time } \\
\text { delay before contamination becomes available for erosion and airborne } \\
\text { suspension. Increasing the cover depth, in some cases, may lead to } \\
\text { lower dose estimates. }\end{array}$ \\
\hline Precipitation (m/yr) & 0.144 & $\begin{array}{l}\text { Appendix B states "Site Specific." The selected value is the average } \\
\text { annual rainfall as recorded at Camp Desert Rock. }\end{array}$ \\
\hline Indoor Time Fraction & 0.1712 & 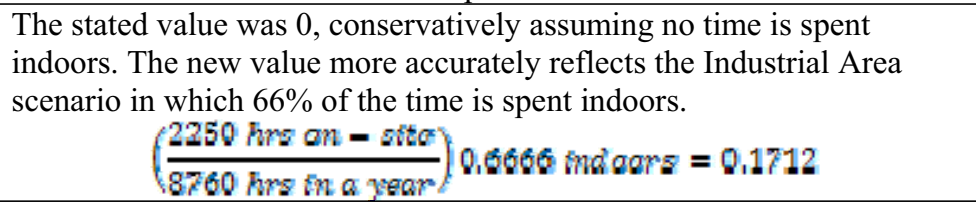 \\
\hline Soil Ingestion Rate (g/yr) & 43.43 & $\begin{array}{l}\text { The stated value was } 108 \text {, assuming that all time is spent outdoors under } \\
\text { a } 480 \mathrm{mg} \text { /day soil ingestion rate. The new value more accurately reflects } \\
\text { the soil ingestion rate of } 193 \mathrm{mg} / \text { day when both indoor and outdoor time } \\
\text { fractions are considered. Refer to page } 14 \text { of NNSA/NSO (2006). }\end{array}$ \\
\hline $\begin{array}{l}\text { Indoor Dust Filtration } \\
\text { Factor }\end{array}$ & 0.4 & $\begin{array}{l}\text { This is the RESRAD default value and is appropriate because, under the } \\
\text { Industrial Area scenario, } 66 \% \text { of the time is spent indoors. }\end{array}$ \\
\hline $\begin{array}{l}\text { Pathway } 1 \text { - External } \\
\text { Gamma }\end{array}$ & Suppressed & $\begin{array}{l}\text { External dose at soils projects will be evaluated via TLDs or direct } \\
\text { measurement with a dose-rate meter. Soil samples and RRMGs are } \\
\text { used to determine the internal dose component only. }\end{array}$ \\
\hline
\end{tabular}

Note: Pathway 1 is suppressed because the $R R M G_{I A}$ values are used to estimate the potential internal dose only. $T L D$ s are used to measure the external dose directly.

$C Z=$ Contamination zone

g/yr $=$ Grams per year $m / y r=$ Meters per year

$m g /$ day $=$ Milligrams per day 
Table 3-2

\begin{tabular}{|c|c|}
\hline Radionuclide & $\begin{array}{c}\mathbf{R R M G}_{\text {IA }} \\
\text { (pCi/g) }\end{array}$ \\
\hline Am-241 & $2.816 \mathrm{E}+03$ \\
\hline Co-60 & $5.513 \mathrm{E}+05$ \\
\hline Cs-137 & $1.409 \mathrm{E}+05$ \\
\hline Eu-152 & $1.177 \mathrm{E}+06$ \\
\hline Eu-154 & $8.469 \mathrm{E}+05$ \\
\hline Eu-155 & $5.588 \mathrm{E}+06$ \\
\hline Pu-238 & $2.423 \mathrm{E}+03$ \\
\hline Pu-239 & $2.215 \mathrm{E}+03$ \\
\hline Pu-240 & $2.215 \mathrm{E}+03$ \\
\hline Sr-90 & $5.947 \mathrm{E}+04$ \\
\hline Th-232 & $2.274 \mathrm{E}+03$ \\
\hline $\mathrm{U}-234$ & $1.960 \mathrm{E}+04$ \\
\hline $\mathrm{U}-235$ & $2.089 \mathrm{E}+04$ \\
\hline $\mathrm{U}-238$ & $2.120 \mathrm{E}+04$ \\
\hline
\end{tabular}

\subsection{Observations Regarding the $R R M G_{I A}$ Values}

The peak or maximum radiation dose occurs in year zero (e.g., the first year of evaluation). Radiation dose then decreases steadily, due to radioactive decay.

Uncertainty in the derivation of dose estimates and dose/source contribution ratios comes from the distribution of possible input parameter values, as well as uncertainty in the conceptual model used to represent the site. The pathways contributing to the total annual dose at the time of maximum dose occurs are inhalation (67 percent) and soil ingestion (33 percent) at year zero. Therefore, uncertainties in the following parameters: soil disturbance (e.g., erosion rates), thickness of contaminated zone, and occupancy factors have the greatest significance on the model predictions.

Of the radionuclides listed in Table 3-2, the plutonium isotopes and Th-232 present the greatest contribution to the overall internal radiation dose, when they are present. This is as expected.

\subsection{Application of Residual Radioactive Material Guidelines}

Single radionuclide guidelines are calculated for individual radionuclides such that the annual dose to a receptor at the site should not exceed an annual dose constraint of $25 \mathrm{mrem} / \mathrm{yr}$. Sites contaminated with two or more radionuclides (i.e., a mixture of radionuclides) require further evaluation to ensure that collective exposures from individual radionuclides do not exceed the 25-mrem/yr-dose constraint. This evaluation is performed using a "sum of the fractions" 
method. The initial soil concentration of each radionuclide is divided by the single radionuclide guideline for that radionuclide to produce a ratio. These ratios are then summed, with the summed value referred to as the sum of the fractions (SoF) for the soil sample.

If the SoF for a soil sample is less than or equal to unity (1), then the collective annual internal dose from all radionuclides at the site should not exceed the $25-\mathrm{mrem} / \mathrm{yr}$ annual dose constraint. To determine the numerical value of the internal dose for a sample, the SoF is multiplied by 25 to yield a product in terms of millirem per Industrial Area year. 


\subsection{References}

DOE, see U.S. Department of Energy.

NNSA/NSO, see U.S. Department of Energy, National Nuclear Security Administration Nevada Site Office.

U.S. Department of Energy. 1993. Radiation Protection of the Public and the Environment, DOE 5400.5. Change 2. Washington, DC.

U.S. Department of Energy, National Nuclear Security Administration Nevada Site Office. 2006. Industrial Sites Project Establishment of Final Action Levels, Rev. 0, DOE/NV--107. Las Vegas, NV.

Yu C., A.J. Zielen, J.J Cheng, D.J. LePoire., E. Gnanapragasam, S. Kamboj, J. Arnish, A. Wallo III, W.A. Williams, and H. Peterson. 2001. User's Manual for RESRAD Version 6, ANL/EAD-4. Argonne, IL: Argonne National Laboratory, Environmental Assessment Division. 


\section{Appendix D}

\section{Closure Activity Summary (Use Restriction)}




\section{D.1.0 Closure Activity Summary}

The following sections document closure activities completed for CAU 371 at CAS 11-23-05 (Pin Stripe) and 18-45-01 (Johnnie Boy). Surface soil samples, TLD measurements, and GWS measurements were collected to characterize the presence and lateral extent of radiological contamination at these sites.

\section{D.1.1 Pin Stripe Closure Activities}

Based on field observations and analytical results for soil samples collected at this CAS, the radiological contamination at the site does not exceed the FAL for the radiological dose (25 mrem/RW-yr). However, it is assumed that subsurface contamination present in the fissure exceeds the FAL and could be uncovered if the site were to be excavated in the future. Therefore, a corrective action of closure in place with a UR was implemented for the subsurface contamination. The UR encompasses the area of the Pin Stripe subsidence crater as well as the identified surface expression of the fissure.

The established UR for Pin Stripe is defined by the coordinates listed in the FFACO UR form and as illustrated in Attachment D-1 of this appendix. The UR is recorded in the FFACO database, NNSA/NSO Facility Information Management System, and the NNSA/NSO CAU/CAS files. Permission to conduct any activities within the FFACO UR area at Johnnie Boy requires prior approval from the NDEP.

\section{D.1.2 Johnnie Boy Closure Activities}

Although no surface soil COCs were identified at Johnnie Boy, it is assumed that subsurface contamination present in the crater (due to direct injection of radionuclides into the subsurface soil from the nuclear test) exceeds the FAL. Therefore, a corrective action of closure in place with a UR was implemented for the subsurface contamination. The UR encompasses the area of the Johnnie Boy crater as well as the ejecta mounds surrounding the crater.

The established FFACO UR for Johnnie Boy is defined by the coordinates listed in the FFACO UR form and as illustrated in Attachment D-1 of this appendix. Additionally, an administrative UR was 
established to prevent more intensive use of the site in the future as discussed and illustrated in Attachment D-1 of this appendix. Both URs are recorded in the FFACO database, NNSA/NSO Facility Information Management System, and the NNSA/NSO CAU/CAS files. Permission to conduct any activities within the FFACO UR area at CAS 18-45-01 requires prior approval from the NDEP. Permission to conduct the following restricted activities within the administrative UR area requires prior approval from the NDEP:

- Full-time work assignments to the site

- Construction of facilities at the site

- Any activity that would result in a worker being assigned to a regular work station within the UR area 


\section{Attachment D-1}

\section{Use Restrictions}

(9 Pages) 


\section{CAU Use Restriction Information}

CAU Number/Description: CAU 371, Johnnie Boy Crater and Pin Stripe

Applicable CAS Number/Description: CAS 11-23-05, Pin Stripe Contamination Area

Contact (Federal Sub-Project Director/Sub-Project): NNSA/NSO Soils Sub-Project Director

Physical Description:

Surveyed Area (UTM, Zone 11, NAD 27, meters):

South/Southeast Corner: $\quad \mathrm{N}=4082597.3 ; \mathrm{E}=594363.8$

South/Southwest Corner: $\quad \mathrm{N}=4082607.0 ; \mathrm{E}=594333.2$

South/Southwest Side: $\quad \mathrm{N}=4082674.3 ; \mathrm{E}=594352.2$

West Corner: $\quad \mathrm{N}=4082700.4 ; \mathrm{E}=594349.1$

Northwest Side: $\quad \mathrm{N}=4082728.8 ; \mathrm{E}=594367.7$

North/Northwest Corner: $\quad \mathrm{N}=4082769.9 ; \mathrm{E}=594379.4$

North/Northeast Corner: $\quad \mathrm{N}=4082761.7 ; \mathrm{E}=594409.4$

Northeast Side: $\quad \mathrm{N}=4082738.8 ; \mathrm{E}=594403.1$

East Corner: $\quad \mathrm{N}=4082708.5 ; \mathrm{E}=594427.8$

East/Southeast Corner: $\quad \mathrm{N}=4082655.2 ; \mathrm{E}=594387.7$

East/Southeast Side $\quad \mathrm{N}=4082655.1 ; \mathrm{E}=594380.4$

Depth: Although this UR is for subsurface contamination within the fissure, it includes the surface and is not limited in depth

Survey Method (GPS, etc):

Basis for UR:

Summary Statement: Subsurface contamination is assumed to be present within the U-11b Pin Stripe fissure from the presence of radioactive materials which vented during the nuclear test. This contamination, if exposed through excavation, could cause a site worker to receive a dose exceeding $25 \mathrm{mrem} / \mathrm{yr}$. No sampling data is available of the subsurface contaminated material.

Contaminants Table:

\begin{tabular}{|c|c|c|c||}
\hline \multicolumn{4}{|c|}{$\begin{array}{c}\text { Maximum Concentration of Contaminants for CAU } 371 \\
\text { CAS 11-23-05, Pin Stripe Contamination Area }\end{array}$} \\
\hline \hline Constituent & Maximum Concentration & Action Level & Units \\
\hline \hline na & na & na & na \\
\hline
\end{tabular}

Site Controls: The use restricted area encompasses the fissure and the potential crater area surrounding the crater. It is established at the boundary identified by the coordinates listed above and depicted in the attached figure. The use restriction postings are placed at approximately 200 -ft intervals surrounding the use restricted area.

UR Maintenance Requirements:

Description: The UR is recorded in the FFACO database, NNSA/NSO Facility Management System, and the NNSA/NSO CAU/CAS files.

Inspection/Maintenance Frequency: Annual post-closure inspections will be conducted to ensure postings are in place, intact, and legible.

Note: Effective upon acceptance of closure documents by NDEP. 
The future use of any land related to this Corrective Action Unit (CAU), as described by the above surveyed location, is restricted from any DOE or Air Force activity that may alter or modify the containment control as approved by the state and identified in the CAU CR or other CAU documentation unless appropriate concurrence is obtained in advance.

Comments: None.

Submitted By: /s/Kevin Cabble

Date: $7-13-10$

Note: Effective upon acceptance of closure documents by NDEP. 


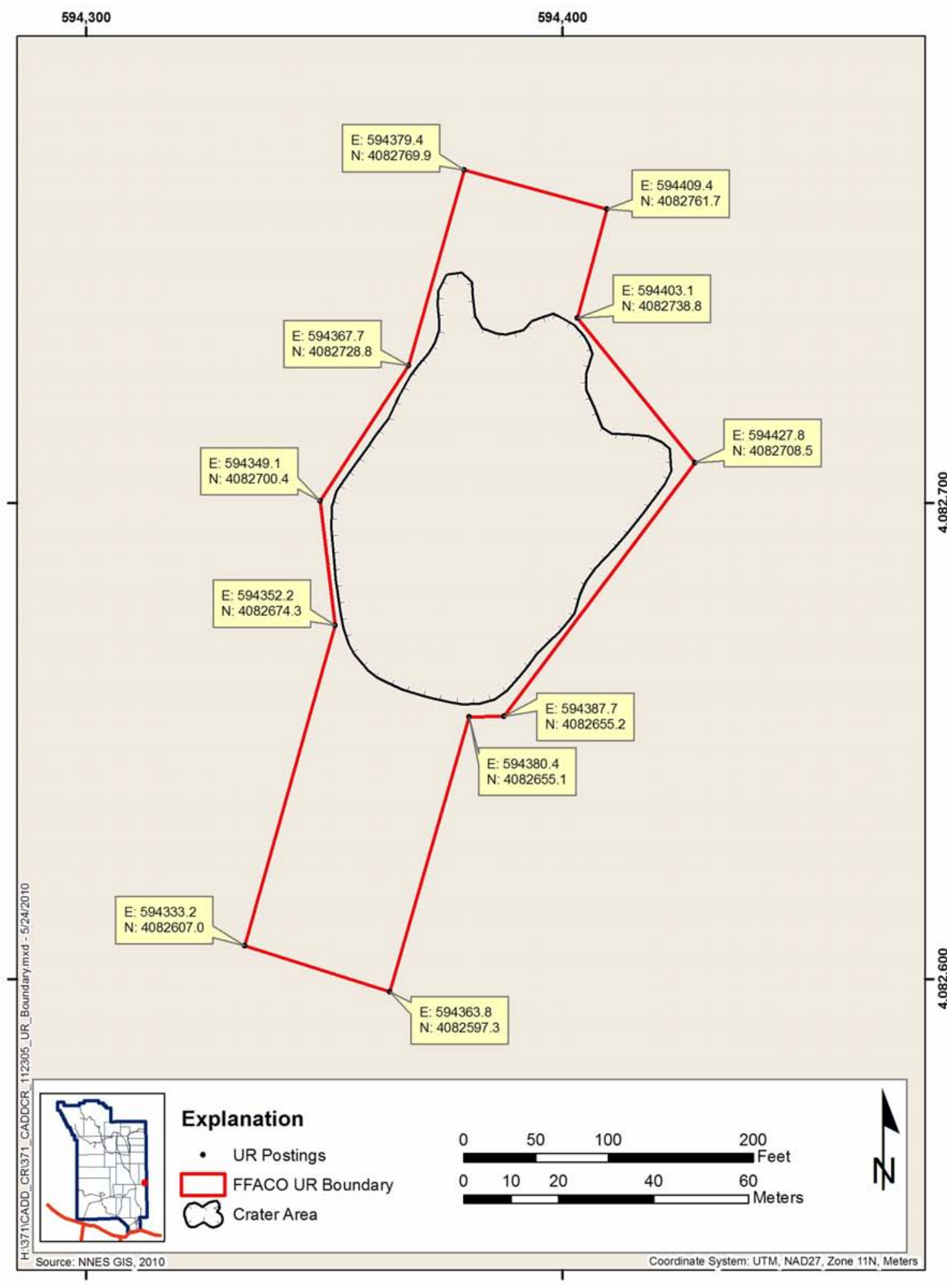

CAU 371, Johnnie Boy Crater and Pin Stripe, CAS 11-23-05, UR Boundary 


\section{CAU Use Restriction Information}

CAU Number/Description: CAU 371, Johnnie Boy Crater and Pin Stripe

Applicable CAS Number/Description: CAS 18-45-01, U-18j-2 Crater (Johnnie Boy)

Contact (Federal Sub-Project Director/Sub-Project): NNSA/NSO Soils Sub-Project Director

Physical Description:

Surveyed Area (UTM, Zone 11, NAD 27, meters):
\begin{tabular}{ll} 
Southeast corner: & $N=4108404.6 ; E=559264.5$ \\
\hline South corner: & $\mathrm{N}=4108393.2 ; \mathrm{E}=559214.9$ \\
\hline South/Southwest corner: & $\mathrm{N}=4108394.6 ; \mathrm{E}=559177.4$ \\
\hline West corner: & $\mathrm{N}=4108431.2 ; \mathrm{E}=559162.8$ \\
\hline West/Northwest corner: & $\mathrm{N}=4108463.4 ; \mathrm{E}=559177.9$ \\
\hline North corner: & $\mathrm{N}=4108498.6 ; \mathrm{E}=559190.5$ \\
\hline North/Northeast corner: & $\mathrm{N}=4108487.4 ; \mathrm{E}=559230.9$ \\
\hline Northeast corner: & $\mathrm{N}=4108469.6 ; \mathrm{E}=559271.2$ \\
\hline East corner: & $\mathrm{N}=4108431.4 ; \mathrm{E}=559294.2$
\end{tabular}

Depth: Although this UR is for subsurface contamination within the crater, it includes the surface and is not limited in depth.

Survey Method (GPS, etc): $\underline{\text { Heads-up digitizing }}$

Basis for UR:

Summary Statement: Subsurface contamination is assumed to be present within the U-18j-2 Johnnie Boy crater from the direct injection of radionuclides into soil from the nuclear test. This contamination, if exposed through excavation, could cause a site worker to receive a dose exceeding $25 \mathrm{mrem} / \mathrm{yr}$. No sampling data is available of the subsurface contaminated material.

Contaminants Table:

\begin{tabular}{|c|c|c|c|}
\hline \multicolumn{4}{|c|}{$\begin{array}{c}\text { Maximum Concentration of Contaminants for CAU 371 } \\
\text { CAS 18-45-01, U-18j-2 Crater (Johnnie Boy) }\end{array}$} \\
\hline \hline Constituent & Maximum Concentration & Action Level & Units \\
\hline na & na & na & na \\
\hline
\end{tabular}

Site Controls: The use restricted area encompasses the crater and the ejecta mounds surrounding the crater. It is established at the boundary identified by the coordinates listed above and depicted in the attached figure. The use restriction postings are placed at approximately 200 -ft intervals surrounding the use restricted area.

UR Maintenance Requirements:

Description: The UR is recorded in the FFACO database, NNSA/NSO Facility Management System, and the NNSA/NSO CAU/CAS files

Inspection/Maintenance Frequency: Annual post-closure inspections will be conducted to ensure postings are in place, intact, and legible.

Note: Effective upon acceptance of closure documents by NDEP. 
The future use of any land related to this Corrective Action Unit (CAU), as described by the above surveyed location, is restricted from any DOE or Air Force activity that may alter or modify the containment control as approved by the state and identified in the CAU CR or other CAU documentation unless appropriate concurrence is obtained in advance.

Comments: None.

Submitted By: /s/Kevin Cabble

Date: $7-13-10$

Note: Effective upon acceptance of closure documents by NDEP. 


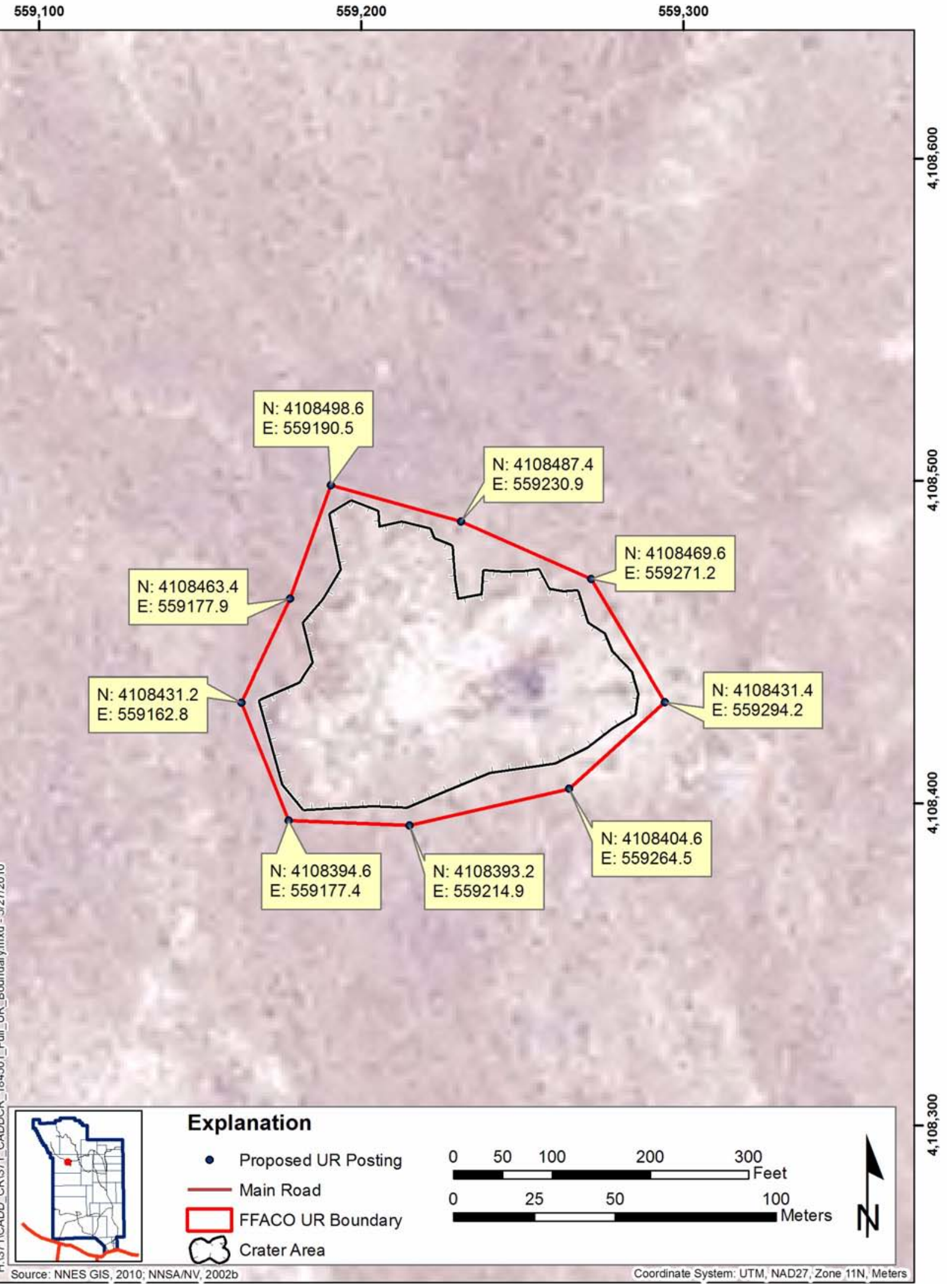

CAU 371, Johnnie Boy Crater and Pin Stripe, CAS 18-45-01, Full UR Boundary 


\section{CAU Use Restriction Information}

CAU Number/Description: CAU 371, Johnnie Boy Crater and Pin Stripe

Applicable CAS Number/Description: CAS 18-45-01, U-18j-2 Crater (Johnnie Boy)

Contact (Federal Sub-Project Director/Sub-Project): NNSA/NSO Soils Sub-Project Director

Physical Description:

Surveyed Area (UTM, Zone 11, NAD 27, meters):

Administrative Use Restriction Coordinates:

Southeast corner: $\quad \mathrm{N}=4108351.1 ; \mathrm{E}=559323.9$

Southwest corner: $\quad \mathrm{N}=4108358.2 ; \mathrm{E}=559190.3$

West corner: $\quad \mathrm{N}=4108502.7 ; \mathrm{E}=559132.7$

Northwest corner: $\quad \mathrm{N}=4108918.5 ; \mathrm{E}=559263.8$

North corner: $\quad \mathrm{N}=4109004.0 ; \mathrm{E}=559308.9$

Northeast corner: $\quad \mathrm{N}=4108919.6 ; \mathrm{E}=559347.0$

East corner: $\quad \mathrm{N}=4108499.9 ; \mathrm{E}=559405.0$

Depth: This administrative UR is to restrict surface soil disturbance to a depth of $2 \mathrm{ft}$ bgs

Survey Method (GPS, etc): Heads-up digitizing

Basis for UR:

Summary Statement: Data from surface sampling indicates that a worker could potentially receive a 25 mrem dose in 990 hours of exposure to the surface location with the maximum detected radioactivity. Current activities at this site do not require site workers to be present for this amount of exposure time. However, as a best management practice, this administrative use restriction will prevent an industrial land use that could cause a full-time industrial site worker to be exposed to site contamination. The analytical results and locations of all samples collected are presented in the CADD/CR for CAU 371.

\section{Contaminants Table:}

\begin{tabular}{|c|c|c|c||}
\hline \multicolumn{5}{|c||}{$\begin{array}{c}\text { Maximum Concentration of Contaminants for CAU 371 } \\
\text { CAS 18-45-01, U-18j-2 Crater (Johnnie Boy) }\end{array}$} \\
\hline \hline Constituent & $\begin{array}{c}\text { Maximum } \\
\text { Concentration }\end{array}$ & Action Level & Units \\
\hline Americium-241 & 0.96 & 9,239 & $\mathrm{pCi} / \mathrm{g}$ \\
\hline Cesium-137 & 62.1 & 487.4 & $\mathrm{pCi} / \mathrm{g}$ \\
\hline Cobalt-60 & 1.45 & 122.5 & $\mathrm{pCi} / \mathrm{g}$ \\
\hline Europium-152 & 16.5 & 255.7 & $\mathrm{pCi} / \mathrm{g}$ \\
\hline Europium-154 & 2.75 & 238.7 & $\mathrm{pCi} / \mathrm{g}$ \\
\hline Plutonium-238 & 0.34 & 13,900 & $\mathrm{pCi} / \mathrm{g}$ \\
\hline Plutonium-239/240 & 6.8 & 12,690 & $\mathrm{pCi} / \mathrm{g}$ \\
\hline Strontium-90 & 6.8 & 55,220 & $\mathrm{pCi} / \mathrm{g}$ \\
\hline Thorium-232 & 2.39 & 3,292 & $\mathrm{pCi} / \mathrm{g}$ \\
\hline Uranium-234 & 22.8 & 131,400 & $\mathrm{pCi} / \mathrm{g}$ \\
\hline Uranium-235 & 0.64 & 1,709 & $\mathrm{pCi} / \mathrm{g}$ \\
\hline Uranium-238 & 1.13 & 9,752 & \\
\hline
\end{tabular}

Note: Effective upon acceptance of closure documents by NDEP. 
Site Controls: This administrative use restriction area is established at the boundary identified by the coordinates listed above and depicted in the attached figure.

UR Maintenance Requirements:

Description: This administrative UR is recorded in the FFACO database, NNSA/NSO Facility Management System, and the NNSA/NSO CAU/CAS files

Inspection/Maintenance Frequency: N/A

The future use of any land related to this Corrective Action Unit (CAU), as described by the above surveyed location, is restricted from any DOE or Air Force activity that may alter or modify the containment control as approved by the state and identified in the CAU CR or other CAU documentation unless appropriate concurrence is obtained in advance.

Comments: Restricted activities include full-time work assignments, construction of facilities, or any activity that would result in a worker being assigned to a regular work station within the use restricted area. Permissible activities include short duration activities such as site visits, maintenance, and retrieval of objects within the use restricted area. Restricted activities would require the prior approval from the NDEP.

Submitted By: /s/Kevin Cabble

Date:

$7-13-10$

Note: Effective upon acceptance of closure documents by NDEP. 


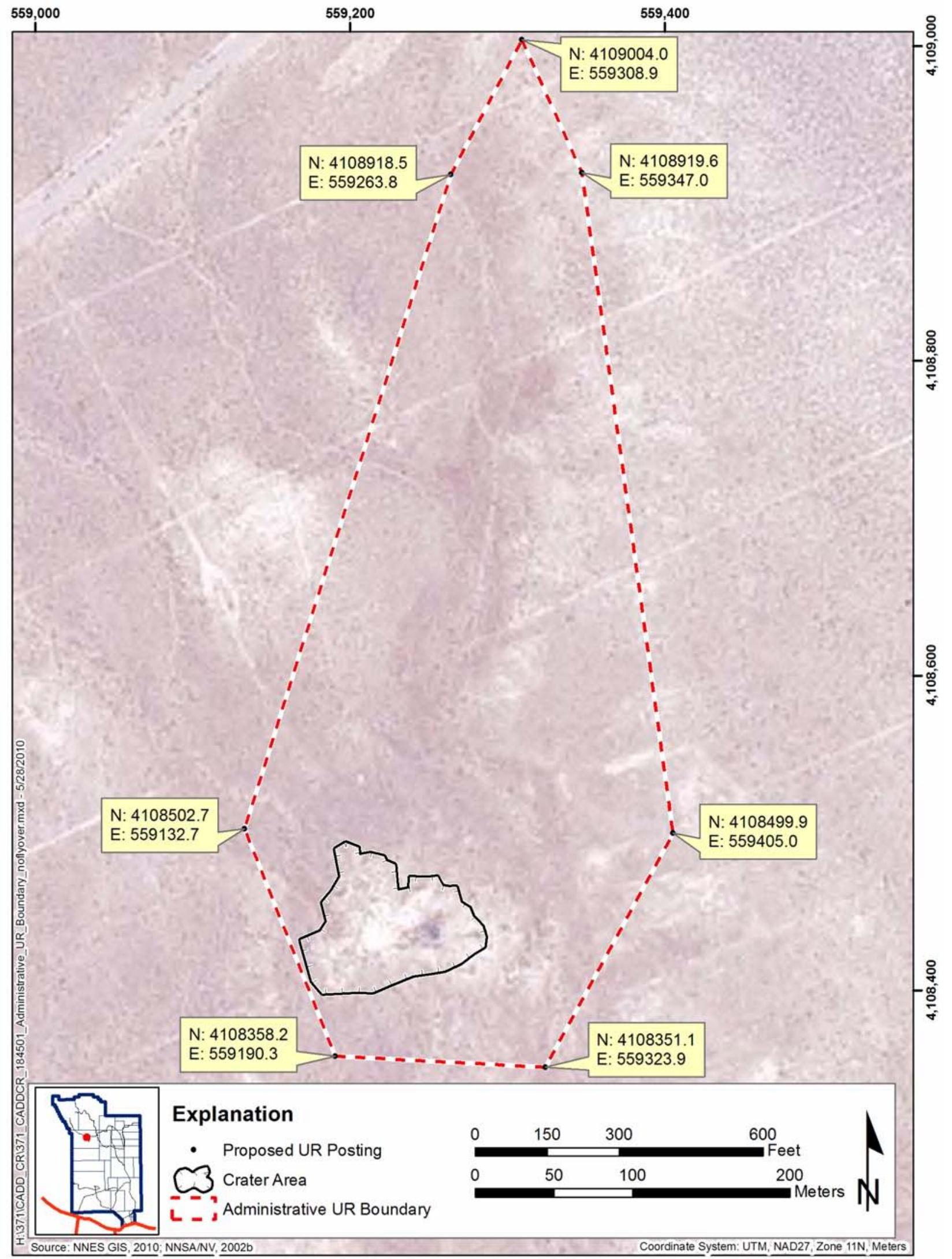

CAU 371, Johnnie Boy Crater and Pin Stripe, CAS 18-45-01, Administrative UR Boundary 


\section{Appendix E}

\section{Evaluation of Corrective Action Alternatives}




\section{E.1.0 Introduction}

This appendix presents the corrective action objectives for CAU 371, describes the general standards and decision factors used to screen the various CAAs, and develops and evaluates a set of selected CAAs that will meet the corrective action objectives.

All CAAs for CAU 371 are based on the presumption that all areas within the current NTS boundary will be controlled in perpetuity and restricted from release to the public. As such, only industrial activities are permitted and risks to receptors under residential scenarios will not be considered. Should the control of the NTS change in the future to include public access or residential use, the selected CAAs may need to be reconsidered.

\section{E.1.1 Corrective Action Objectives}

On May 1, 1996, EPA issued an Advance Notice of Proposed Rulemaking (ANPR) for corrective action for releases from solid waste management units at hazardous waste management facilities (EPA, 1996). The EPA states that the ANPR should be considered the primary corrective action implementation guidance (Laws and Herman, 1997). The ANPR states that a basic operating principle for remedy selection is that corrective action decisions should be based on risk. It emphasizes that current and reasonably expected future land use should be considered when selecting corrective action remedies and encourages use of innovative site characterization techniques to expedite site investigations.

The ANPR provides the following EPA expectations for corrective action remedies (EPA, 1996):

- Treatment should be used to address principle threats wherever practicable and cost effective.

- Engineering controls, such as containment, should be used where wastes and contaminated media can be reliably contained, pose relatively low long-term threats, or for which treatment is impracticable.

- A combination of methods (e.g., treatment, engineering, and institutional controls) should be used, as appropriate, to protect human health and the environment.

- Institutional controls should be used primarily to supplement engineering controls as appropriate for short- or long-term management to prevent or limit exposure. 
- Innovative technologies should be considered where such technologies offer potential for comparable or superior performance or implementability, less adverse impacts, or lower costs.

- Usable groundwater should be returned to maximum beneficial use wherever practicable.

- Contaminated soils should be remediated as necessary to prevent or limit direct exposure and to prevent the transfer of unacceptable concentrations of contaminants from soils to other media

Implementation of the corrective action will ensure that contaminants remaining at each release site will not pose an unacceptable risk to human health and the environment, and that conditions at each site are in compliance with all applicable laws and regulations.

\section{E.1.2 Screening Criteria}

The screening criteria used to evaluate and select the preferred CAA are identified in the Guidance on RCRA Corrective Action Decision Documents (EPA, 1991) and the Final RCRA Corrective Action Plan (EPA, 1994).

Corrective action alternatives are evaluated based on four general corrective action standards and five remedy selection decision factors. All CAAs must meet the four general standards to be selected for evaluation using the remedy selection decision factors.

The general corrective action standards are as follows:

- Protection of human health and the environment

- Compliance with media cleanup standards

- Control the source(s) of the release

- Comply with applicable federal, state, and local standards for waste management

The remedy selection decision factors are as follows:

- Short-term reliability and effectiveness

- Reduction of toxicity, mobility, and/or volume

- Long-term reliability and effectiveness

- Feasibility

- Cost 


\section{E.1.3 Corrective Action Standards}

The following subsections describe the corrective action standards used to evaluate the CAAs.

\section{Protection of Human Health and the Environment}

Protection of human health and the environment is a general mandate of the RCRA statute (EPA, 1994). This mandate requires that the corrective action include any necessary protective measures necessary to ensure the requirements are met. These measures may or may not be directly related to media cleanup, source control, or management of wastes.

\section{Compliance with Media Cleanup Standards}

The CAAs are evaluated for the ability to meet the proposed media cleanup standards. The media cleanup standards are the FALs.

\section{Control the Source(s) of the Release}

The CAAs are evaluated for the ability to stop further environmental degradation by controlling or eliminating additional releases that may pose a threat to human health and the environment. Unless source control measures are taken, efforts to clean up releases may be ineffective or, at best, will involve a perpetual cleanup. Therefore, each CAA must provide effective source control to ensure the long-term effectiveness and protectiveness of the corrective action.

\section{Comply with Applicable Federal, State, and Local Standards for Waste Management}

The CAAs are evaluated for the ability to be conducted in accordance with applicable federal and state regulations (e.g., 40 CFR 260 to 282, "Hazardous Waste Management” [CFR, 2008a]; 40 CFR 761 "Polychlorinated Biphenyls," [CFR, 2008b]; and NAC 444.842 to 98, "Management of Hazardous Waste” [NAC, 2008]).

\section{E.1.3.1 Remedy Selection Decision Factors}

The following text describes the remedy selection decision factors used to evaluate the CAAs. 


\section{Short-Term Reliability and Effectiveness}

Each CAA must be evaluated with respect to its effects on human health and the environment during implementation of the selected corrective action. The following factors will be addressed for each alternative:

- Protection of the community from potential risks associated with implementation, (e.g., fugitive dusts, transportation of hazardous materials, and explosion)

- Protection of workers during implementation

- Adverse environmental impacts that may result from implementation

- The amount of time until the corrective action objectives are achieved

\section{Reduction of Toxicity, Mobility, and/or Volume}

Each CAA must be evaluated for its ability to reduce the toxicity, mobility, and/or volume of the contaminated media. Reduction in toxicity, mobility, and/or volume refers to changes in one or more characteristics of the contaminated media by using corrective measures that decrease the inherent threats associated with that media.

\section{Long-Term Reliability and Effectiveness}

Each CAA must be evaluated in terms of risk remaining at the CAU after the CAA has been implemented. The primary focus of this evaluation is on the extent and effectiveness of the control that may be required to manage the risk posed by treatment of residuals and/or untreated wastes.

\section{Feasibility}

The feasibility criterion addresses the technical and administrative feasibility of implementing a CAA and the availability of services and materials needed during implementation. Each CAA must be evaluated for the following criteria:

- Construction and Operation - The feasibility of implementing a CAA given the existing set of waste and site-specific conditions.

- Administrative Feasibility - The administrative activities needed to implement the CAA (e.g., permits, URs, public acceptance, rights of way, offsite approval). 
- Availability of Services and Materials - The availability of adequate offsite and onsite treatment, storage capacity, disposal services, necessary technical services and materials, and prospective technologies for each CAA.

\section{Cost}

Costs for each alternative are estimated for comparison purposes only. The cost estimate for each CAA includes both capital, and operation and maintenance costs, as applicable, and are provided in Section E.3.0. The following is a brief description of each component:

- Capital Costs - Costs that include direct costs that may consist of materials, labor, construction materials, equipment purchase and rental, excavation and backfilling, sampling and analysis, waste disposal, demobilization, and health and safety measures. Indirect costs are separate and not included in the estimates.

- Operation and Maintenance - Separate costs that include labor, training, sampling and analysis, maintenance materials, utilities, and health and safety measures. These costs are not included in the estimates.

\section{E.1.4 Development of Corrective Action Alternatives}

This section identifies and briefly describes the viable corrective action technologies and the CAAs considered for Pin Stripe and Johnnie Boy. Contamination providing a dose exceeding the $25 \mathrm{mrem} / \mathrm{RW}$-yr FAL was not present in surface soils at these CASs but was assumed to be present in subsurface soils in the Pin Stripe fissure and in the Johnnie Boy crater.

Based on the review of existing data, future use, and current operations at the NTS, the following alternatives have been developed for consideration at CAU 371:

- Alternative 1 - No Further Action

- Alternative 2 - Clean Closure

- Alternative 3 - Closure in Place

\section{E.1.4.1 Alternative 1 - No Further Action}

Under the no further action alternative, no corrective action activities will be implemented. This alternative is a baseline case with which to compare and assess the other CAAs and their ability to meet the corrective action standards. 


\section{E.1.4.2 Alternative 2 - Clean Closure}

Alternative 2 includes excavating and disposing of impacted soil and debris presenting a dose exceeding the 25-mrem/RW-yr FAL to a depth of 25 feet (ft) bgs (the maximum depth to which a construction activity might excavate for a building foundation or basement). A visual inspection will be conducted to ensure that contaminated surface debris have been removed before the completion of the corrective action. Verification soil samples will also be collected and analyzed for the presence of a dose exceeding the 25-mrem/RW-yr FAL following removal of contaminated soil.

Contaminated materials removed will be disposed of at an appropriate disposal facility. Excavated areas will be returned to surface conditions compatible with the intended future use of the site.

\section{E.1.4.3 Alternative 3 - Closure in Place}

For radiological contamination, Alternative 3 includes the implementation of a UR where a radiological dose is present at levels that exceed the $25 \mathrm{mrem} / \mathrm{RW}$-yr FAL. This UR will restrict inadvertent contact with contaminated media by prohibiting any activity that would cause a site worker to be exposed to a dose exceeding $25 \mathrm{mrem} / \mathrm{yr}$. Under this alternative, debris within the 25-mrem/RW-yr FAL area will not be removed.

\section{E.1.5 Evaluation and Comparison of Alternatives}

Each CAA presented in Section E.1.4 will be evaluated based on the general corrective action standards listed in Section E.1.2. This evaluation is presented in Table E.1-1. Any CAA that does not meet the general corrective action standards will be removed from consideration.

Only CAAs 2 and 3 met the corrective action standard and will be further evaluated based on the remedy selection decision factors described in Section E.1.2. This evaluation is presented in Table E.1-2. For each remedy selection decision factor, the CAAs are ranked relative to one another. The CAA with the least desirable impact on the remedy selection decision factor will be given a ranking of 1 . The CAAs with increasingly desirable impacts on the remedy selection decision factor will receive increasing rank numbers. The CAAs that will have an equal impact on the remedy selection decision factor will receive an equal ranking number. The scoring listed in this table represents the sum of the remedy selection decision factor rankings for each CAA. 
Table E.1-1

Evaluation of General Corrective Action Standards

CAS 11-23-05, Pin Stripe Contamination Area, and CAS 18-45-01, U-18j-2 Crater (Johnnie Boy)

\begin{tabular}{|c|c|c|}
\hline \multicolumn{3}{|c|}{ CAA 1, No Further Action } \\
\hline Standard & Comply? & Explanation \\
\hline Protection of Human Health and the Environment & No & $\begin{array}{l}\text { Subsurface contamination is present that could } \\
\text { provide an excavation worker a dose exceeding the } \\
25-\mathrm{mrem} / \mathrm{RW}-\mathrm{yr} \text { FAL. }\end{array}$ \\
\hline Compliance with Media Cleanup Standards & No & $\begin{array}{l}\text { Subsurface contamination is present that could } \\
\text { provide an excavation worker a dose exceeding the } \\
\text { 25-mrem/RW-yr FAL. }\end{array}$ \\
\hline Control the Source(s) of the Release & Yes & $\begin{array}{l}\text { Only subsurface contamination is present exceeding } \\
\text { the } 25-\mathrm{mrem} / \mathrm{RW}-\mathrm{yr} \mathrm{FAL} \text { and is not subject to } \\
\text { significant migration. }\end{array}$ \\
\hline $\begin{array}{l}\text { Comply with Applicable Federal, State, and Local } \\
\text { Standards for Waste Management }\end{array}$ & Yes & This alternative will not generate waste. \\
\hline \multicolumn{3}{|c|}{ CAA 2, Clean Closure } \\
\hline Standard & Comply? & Explanation \\
\hline Protection of Human Health and the Environment & Yes & $\begin{array}{l}\text { Contamination exceeding the risk-based action levels } \\
\text { will be removed. }\end{array}$ \\
\hline Compliance with Media Cleanup Standards & Yes & $\begin{array}{l}\text { Contamination exceeding the risk-based action levels } \\
\text { will be removed. }\end{array}$ \\
\hline Control the Source(s) of the Release & Yes & $\begin{array}{l}\text { Contamination exceeding the risk-based action levels } \\
\text { will be removed. }\end{array}$ \\
\hline $\begin{array}{l}\text { Comply with Applicable Federal, State, and Local } \\
\text { Standards for Waste Management }\end{array}$ & Yes & $\begin{array}{l}\text { Excavated waste can be managed in compliance with } \\
\text { all standards. }\end{array}$ \\
\hline \multicolumn{3}{|c|}{ CAA 3, Closure in Place with Administrative Controls } \\
\hline Standard & Comply? & Explanation \\
\hline Protection of Human Health and the Environment & Yes & $\begin{array}{l}\text { A UR will be implemented to protect excavation } \\
\text { workers from inadvertant dose. }\end{array}$ \\
\hline Compliance with Media Cleanup Standards & Yes & $\begin{array}{l}\text { Although COCs will not be removed, site will be } \\
\text { controlled to prevent workers from receiving a dose } \\
\text { exceeding the } 25-\mathrm{mrem} / \mathrm{RW}-\mathrm{yr} \text { FAL. }\end{array}$ \\
\hline Control the Source(s) of the Release & Yes & $\begin{array}{l}\text { Only subsurface contamination is present exceeding } \\
\text { the } 25-\mathrm{mrem} / \mathrm{RW}-\mathrm{yr} \text { FAL and is not subject to } \\
\text { significant migration. }\end{array}$ \\
\hline $\begin{array}{l}\text { Comply with Applicable Federal, State, and Local } \\
\text { Standards for Waste Management }\end{array}$ & Yes & This alternative will not generate waste. \\
\hline
\end{tabular}


Table E.1-2

Evaluation of Remedy Selection Decision Factors

CAS 11-23-05, Pin Stripe Contamination Area, and CAS 18-45-01, U-18j-2 Crater (Johnnie Boy)

\begin{tabular}{|c|c|c|}
\hline \multicolumn{3}{|c|}{ CAA 1, No Further Action } \\
\hline Factor & Rank & Explanation \\
\hline \multicolumn{3}{|c|}{ Not evaluated, as this CAA did not meet the General Corrective Action Standards } \\
\hline \multicolumn{3}{|c|}{ CAA 2, Clean Closure } \\
\hline Standard & Rank & Explanation \\
\hline Short-Term Reliability and Effectiveness & 1 & $\begin{array}{l}\text { This alternative is reliable and effective, but involves increased } \\
\text { short-term exposure of site workers to COCs during soil } \\
\text { removal operations. }\end{array}$ \\
\hline Reduction of Toxicity, Mobility, and/or Volume & 2 & $\begin{array}{l}\text { This alternative will result in a decrease of toxicity and mobility, } \\
\text { but will generate significant waste volumes. }\end{array}$ \\
\hline Long-Term Reliability and Effectiveness & 2 & $\begin{array}{l}\text { This alternative is reliable and effective at protecting human } \\
\text { health and the environment because removal of the } \\
\text { contaminated media will eliminate future exposure of site } \\
\text { workers to COCs. However, the short term exposure to site } \\
\text { workers would increase. }\end{array}$ \\
\hline Feasibility & 1 & Removal of deep subsurface contamination is not feasible. \\
\hline Cost & 1 & Cost is estimated to be in excess of $\$ 90$ million. \\
\hline Score & 7 & \\
\hline \multicolumn{3}{|c|}{ CAA 3, Closure in Place with Administrative Controls } \\
\hline Standard & Rank & Explanation \\
\hline Short-Term Reliability and Effectiveness & 2 & $\begin{array}{l}\text { This alternative is reliable and effective in providing increased } \\
\text { protection of human health by preventing contact with cOCs. }\end{array}$ \\
\hline Reduction of Toxicity, Mobility, and/or Volume & 1 & $\begin{array}{l}\text { This alternative will not reduce toxicity or mobility of the } \\
\text { COCs that are present, but will not generate excavation } \\
\text { waste volumes. }\end{array}$ \\
\hline Long-Term Reliability and Effectiveness & 1 & $\begin{array}{l}\text { This alternative is reliable in the long term with ongoing } \\
\text { maintenance. It is effective in providing protection of human } \\
\text { health by preventing inadvertent contact with COCs. }\end{array}$ \\
\hline Feasibility & 2 & $\begin{array}{l}\text { This alternative is easily implemented, but requires } \\
\text { maintenance and long-term monitoring. }\end{array}$ \\
\hline Cost & 2 & $\begin{array}{l}\text { The installation costs are estimated at } \$ 25,000 \text {. Ongoing } \\
\text { maintenance costs for this alternative are estimated at } \\
\$ 1,000 \text { annually. }\end{array}$ \\
\hline Score & 8 & \\
\hline
\end{tabular}


The five EPA remedy selection decision factors are short-term reliability and effectiveness; reduction of toxicity, mobility, and/or volume; long-term reliability and effectiveness; feasibility; and cost. These factors are provided in Table E.1-2.

The first remedy selection decision factor-short-term reliability and effectiveness - is a qualitative measure of the impacts on human health and the environment during implementation of the CAA. While clean closure is both reliable and effective in the long-term, this alternative involves increased, short-term exposure of site workers to radiological contamination during soil and debris removal. In contrast, closure in place does not require removal of soil, and there is no short-term exposure of site workers; signs are posted, and disturbance of contaminated soil and debris is not necessary.

The second remedy selection decision factor-reduction of toxicity, mobility, and/or volume — is a qualitative measure of changes in characteristics of contaminated media that result from implementation of the CAA. Under clean closure, contaminated media that exceed FALs (to a depth of $25 \mathrm{ft}$ bgs) would be removed from the area, thereby eliminating both mobility and the onsite volume of contaminated media. In contrast, closure in place does not reduce toxicity, mobility, or volume.

The third remedy selection decision factor-long-term reliability and effectiveness — is a qualitative evaluation of performance following site closure, and into the future. Removal of contaminated media for clean closure provides long-term reliability and effectiveness, whereas closure in place does not.

The fourth remedy selection decision factor-feasibility_-includes an evaluation of the requirements for construction and operation as well as administrative constraints. For the closure in place alternative, no construction is required other than the installation of postings. Some maintenance and administrative requirements would be onging. For the clean closure alternative, substantial construction, operation, and administrative actions consistent with soil removal and management of generated wastes are needed. 
The fifth remedy selection decision factor — cost—includes assessment of both capital (direct) costs of implementation and costs for operation and maintenance of the corrective action. As shown in Table E.1-2, the estimated cost for clean closure would exceed \$90 million, while the costs for closure in place are limited to those derived from acquiring, hanging, inspecting, and occasionally replacing, UR signs (estimated to be $\$ 25,000$ for the first year and $\$ 1,000$ for each year thereafter). 


\section{E.2.0 Recommended Alternative}

Three CAAs were evaluated for Pin Stripe and Johnnie Boy: no further action (CAA 1), clean closure (CAA 2), and closure in place (CAA 3). Only CAA 2 and CAA 3 met all requirements for general corrective action standards (Section E.1.2). In general, for the clean closure alternative, near-surface soils would be removed from the sites to a depth of $25 \mathrm{ft}$ bgs. For the closure in place alternative, potential worker exposure to radiological contamination would be controlled through the implementation of URs. Both CAAs would, therefore, be protective of human health and the environment, comply with media cleanup standards, and control the source of release. As supported by the following discussion, further examination of the two CAAs by the five EPA remedy selection decision factors resulted in the selection of closure in place as the preferred CAA for both Pin Stripe and Johnnie Boy.

Based upon the five remedy selection decision factors, clean closure received an overall score of 7 (less desirable), whereas closure in place received an overall score of 8 (more desirable). This result was not only the product of an examination of the two CAAs by the five remedy selection decision factors, but also in consideration of the current NTS administrative controls (e.g., NTS access restrictions and control of site activities), the remoteness of the sites, no nearby structures or activities, no current or planned use of the sites, the present-day stability of the contaminated soil at the sites through the evolution of a mature plant community, and the development of soil surface durability (i.e., soil crust). Also, the clean closure alternative is not feasible at either CAS. The subsurface contamination at Pin Stripe is located within a potential subsidence crater area. As this area is still subject to potential subsidence, excavation workers removing the contaminated subsurface material would be subject to unacceptable risk. The subsurface contamination at Johnnie Boy is located underneath a 9-m-deep crater. To excavate this contaminated material would require the removal of approximately 60,000 cubic yards $\left(\mathrm{yd}^{3}\right)$ of clean material before access would be gained to the approximately $15,000 \mathrm{yd}^{3}$ of contaminated material. Currently, this contaminated material beneath the Johnnie Boy crater is covered by clean eroded material and is not accessible to expose workers or the public to radioactivity. Therefore, this removal action would pose significant safety risks, be extremely difficult and expensive, and would not provide significant additional protection to potential future receptors. 
Therefore, selection of the CAA of closure in place for both Pin Stripe and Johnnie Boy is consistent with past practices for CASs that contain COCs and where there would be significant costs and short-term health risks to workers involved in cleanup activities. However, if, the control of the NTS should change in the future to include public access or residential use, the selected CAAs may need to be reconsidered. 


\section{E.3.0 Cost Estimates}

The cost estimate for clean closure is estimated to exceed $\$ 90$ million to conduct the following activities:

- Preparation and procurement

- Grub surface contamination

- Excavate, load, and dispose contaminated soil (approximately 302,070,000 cubic feet)

- Dispose of debris

- Equipment decontamination

The estimated costs for clean closure of CAU 371 was based on removing contaminated soil within the $25 \mathrm{mrem} / \mathrm{yr}$ boundary. Specifically, soil within the fissure and t-posted crater area at Pin Stripe would be removed. The cost for clean closure of Pin Stripe was estimated to be more than $\$ 30$ million. For Johnnie Boy, soil within the 32,000 cps isopleth from the 2008 flyover survey (25-mrem/yr boundary) would be removed (NNSA/NSO, 2009). The cost for clean closure of Johnnie Boy was estimated to be approximately $\$ 60$ million. This includes excavation, loading and processing, transportation, disposal, site restoration, and site support.

The costs for closure in place, however, are limited to those derived from acquiring, hanging, inspecting, and occasionally replacing, UR signs, and are estimated to be approximately $\$ 25,000$ for the first year and $\$ 1,000$ for each year thereafter. 


\section{E.4.0 References}

CFR, see Code of Federal Regulations.

Code of Federal Regulations. 2008a. Title 40 CFR Parts 260 - 282, “Hazardous Waste Management.” Washington, DC: U.S. Government Printing Office.

Code of Federal Regulations. 2008b. Title 40 CFR 761, "Polychlorinated Biphenyls (PCBs) Manufacturing, Processing, Distribution in Commerce and Prohibitions.” Washington, DC: U.S. Government Printing Office.

EPA, see U.S. Environmental Protection Agency.

Laws, E.P., and S.A. Herman, U.S. Environmental Protection Agency. 1997. Memorandum to RCRA/CERCLA Senior Policy Managers Region I-X titled "Use of the Corrective Action Advance Notice of Proposed Rulemaking as Guidance,” 17 January. Washington, DC: Offices of Solid Waste and Emergency Response, and Enforcement and Compliance Assurance.

NAC, see Nevada Administrative Code.

NNSA/NSO, see U.S. Department of Energy, National Nuclear Security Administration Nevada Site Office.

Nevada Administrative Code. 2008. NAC 445A, "Water Controls.” Carson City, NV. As accessed at http://www.leg.state.nv.us/nac on 8 April 2010.

U.S. Department of Energy, National Nuclear Security Administration Nevada Site Office. 2009. An Aerial Radiological Survey of Selected Areas of Area 18 - Nevada Test Site, DOE/NV/25946--767. Prepared by C. Lyons for National Security Technologies, LLC. Las Vegas, NV: Remote Sensing Laboratory.

U.S. Environmental Protection Agency. 1991. Guidance on RCRA Corrective Action Decision Documents: The Statement of Bases, Final Decision and Response to Comments, EPA/540/G-91/011. Washington, DC: Office of Waste Programs Enforcement.

U.S. Environmental Protection Agency. 1994. Final RCRA Corrective Action Plan, EPA/520-R-94-004. Washington, DC: Office of Solid Waste and Emergency Response.

U.S. Environmental Protection Agency. 1996. “Corrective Action for Releases from Solid Waste Management Units at Hazardous Waste Management Facilities,” 1 May. In Federal Register, Vol. 61, No. 85. 


\section{Appendix F}

\section{Composite Sample Plot Analytical Data}




\section{F.1.0 Composite Sample Analytical Data for Pin Stripe}

Analytical results for gamma-emitting and isotopic radionuclide environmental samples collected at the sample plots at Pin Stripe that were detected above MDCs are presented in the following tables. Because individual radionuclide results were not used for decisions, these results are presented in this appendix for completeness.

- $\quad$ Sample plot AA: Tables F.1-1 through F.1-3

- Sample plot AB: Tables F.1-4 through F.1-6

- Sample plot AC: Tables F.1-7 through F.1-9

- Sample plot AE: Tables F.1-10 through F.1-12

- Sample plot AF: Tables F.1-13 through F.1-15

Table F.1-1

Sample Results for Gamma-Emitting Radionuclides Detected above MDCs at Sample Plot AA

\begin{tabular}{|c|c|c|c|c|c|c|c|c|}
\hline \multirow{2}{*}{$\begin{array}{c}\text { Sample } \\
\text { Location }\end{array}$} & \multirow{2}{*}{$\begin{array}{l}\text { Sample } \\
\text { Number }\end{array}$} & \multirow{2}{*}{$\begin{array}{c}\text { Depth } \\
\text { (cm bgs) }\end{array}$} & \multicolumn{6}{|c|}{ COPCs (pCi/g) } \\
\hline & & & Ac-228 & Cs-137 & Eu-152 & $\mathrm{Pb}-212$ & $\mathrm{~Pb}-214$ & TI-208 \\
\hline \multicolumn{3}{|c|}{ FALs } & 5 & 12.2 & 5.67 & 5 & 5 & 5 \\
\hline \multirow{2}{*}{ AA1 } & 371AA01 & $0.0-5.0$ & 1.89 & 67.5 & 0.47 & 2 & $1.42(\mathrm{~J})$ & 0.65 \\
\hline & 371AA02 & $0.0-5.0$ & 1.99 & 50.5 & -- & 1.83 & $1.31(\mathrm{~J})$ & 0.7 \\
\hline AA2 & 371AA03 & $0.0-5.0$ & 2.05 & 42.8 & -- & 2.23 & $1.47(\mathrm{~J})$ & 0.69 \\
\hline AA3 & 371AA04 & $0.0-5.0$ & 2.17 & 48.8 & -- & $2.02(\mathrm{~J})$ & $1.6(\mathrm{~J})$ & 0.67 \\
\hline AA4 & 371AA05 & $0.0-5.0$ & 2.01 & 57 & 0.41 & 2.05 & $1.4(\mathrm{~J})$ & 0.64 \\
\hline
\end{tabular}

Ac $=$ Actinium

$\mathrm{Pb}=$ Lead

$\mathrm{TI}=$ Thallium

$\mathrm{J}=$ Estimated value

-- = Not detected above MDCs.

Bold indicates the values exceeding the FALs. 
Table F.1-2

Sample Results for Am-241 Detected above MDCs at Sample Plot AA

\begin{tabular}{|c|c|c|c|}
\hline \multirow{2}{*}{$\begin{array}{l}\text { Sample } \\
\text { Location }\end{array}$} & \multirow{2}{*}{$\begin{array}{l}\text { Sample } \\
\text { Number }\end{array}$} & \multirow{2}{*}{$\begin{array}{c}\text { Depth } \\
\text { (cm bgs) }\end{array}$} & COPCs (pCi/g) \\
\hline & & & Am-241 \\
\hline \multicolumn{3}{|c|}{ FALs } & 12.7 \\
\hline \multirow{2}{*}{ AA1 } & 371AA01 & $0.0-5.0$ & 0.44 \\
\hline & 371AA02 & $0.0-5.0$ & 0.307 \\
\hline AA2 & 371AA03 & $0.0-5.0$ & 0.37 \\
\hline AA3 & 371AA04 & $0.0-5.0$ & 0.43 \\
\hline AA4 & 371AA05 & $0.0-5.0$ & 0.31 \\
\hline
\end{tabular}

Table F.1-3

Sample Results for Isotopes Detected above MDCs at Sample Plot AA

\begin{tabular}{|c|c|c|c|c|c|c|c|}
\hline \multirow{2}{*}{$\begin{array}{l}\text { Sample } \\
\text { Location }\end{array}$} & \multirow{2}{*}{$\begin{array}{l}\text { Sample } \\
\text { Number }\end{array}$} & \multirow{2}{*}{$\begin{array}{c}\text { Depth } \\
\text { (cm bgs) }\end{array}$} & \multicolumn{5}{|c|}{ COPCs (pCi/g) } \\
\hline & & & Pu-238 & $\mathrm{Pu}-239 / 240$ & Sr-90 & U-234 & U-238 \\
\hline \multicolumn{3}{|c|}{ FALs } & 13 & 12.7 & 838 & 143 & 105 \\
\hline \multirow{2}{*}{ AA1 } & 371AA01 & $0.0-5.0$ & 1.36 & 2.72 & 3.1 & 1.17 & 1.15 \\
\hline & 371AA02 & $0.0-5.0$ & 0.71 & 1.57 & 3.5 & 1.24 & 1.29 \\
\hline AA2 & 371AA03 & $0.0-5.0$ & 0.79 & 1.5 & 3.2 & 1.49 & 1.33 \\
\hline AA3 & 371AA04 & $0.0-5.0$ & 0.96 & 2.22 & 1.91 & 1.14 & 1.11 \\
\hline AA4 & 371AA05 & $0.0-5.0$ & 0.81 & 1.62 & 4.1 & 1.26 & 1.42 \\
\hline
\end{tabular}


Table F.1-4

Sample Results for Gamma-Emitting Radionuclides Detected above MDCs at Sample Plot AB

\begin{tabular}{|c|c|c|c|c|c|c|c|c|c|}
\hline \multirow{2}{*}{$\begin{array}{l}\text { Sample } \\
\text { Location }\end{array}$} & \multirow{2}{*}{$\begin{array}{l}\text { Sample } \\
\text { Number }\end{array}$} & \multirow{2}{*}{$\begin{array}{c}\text { Depth } \\
\text { (cm bgs) }\end{array}$} & \multicolumn{7}{|c|}{ COPCs (pCi/g) } \\
\hline & & & Ac-228 & Co-60 & Cs-137 & Eu-152 & $\mathrm{Pb}-212$ & $\mathrm{~Pb}-214$ & TI-208 \\
\hline \multicolumn{3}{|c|}{ FALs } & 5 & 2.68 & 12.2 & 5.67 & 5 & 5 & 5 \\
\hline AB1 & $371 \mathrm{AB} 01$ & $0.0-5.0$ & 2.13 & -- & 100 & 0.4 & 2.17 & $1.53(\mathrm{~J})$ & 0.62 \\
\hline AB2 & 371AB02 & $0.0-5.0$ & 2.06 & 0.109 & 186 & $1(\mathrm{~J})$ & $1.51(\mathrm{~J})$ & $1.47(\mathrm{~J})$ & 0.72 \\
\hline AB3 & 371AB03 & $0.0-5.0$ & 2.23 & -- & 168 & 1.05 & 1.98 & $1.53(\mathrm{~J})$ & 0.67 \\
\hline AB4 & 371AB04 & $0.0-5.0$ & 1.91 & -- & 106 & 0.59 & 1.93 & $1.39(\mathrm{~J})$ & 0.62 \\
\hline
\end{tabular}

$\mathrm{J}=$ Estimated value

$--=$ Not detected above MDCs.

Bold indicates the values exceeding the FALs.

Table F.1-5

Sample Results for Am-241 Detected above MDCs at Sample Plot AB

\begin{tabular}{|c|c|c|c|}
\hline \multirow{2}{*}{$\begin{array}{l}\text { Sample } \\
\text { Location }\end{array}$} & \multirow{2}{*}{$\begin{array}{l}\text { Sample } \\
\text { Number }\end{array}$} & \multirow{2}{*}{$\begin{array}{c}\text { Depth } \\
\text { (cm bgs) }\end{array}$} & COPCs (pCi/g) \\
\hline & & & Am-241 \\
\hline \multicolumn{3}{|c|}{ FALs } & 12.7 \\
\hline $\mathrm{AB1}$ & 371AB01 & $0.0-5.0$ & 0.47 \\
\hline $\mathrm{AB} 2$ & 371AB02 & $0.0-5.0$ & 1.06 \\
\hline AB3 & 371AB03 & $0.0-5.0$ & 1.29 \\
\hline AB4 & $371 \mathrm{AB} 04$ & $0.0-5.0$ & 1.12 \\
\hline
\end{tabular}


Table F.1-6

Sample Results for Isotopes Detected above MDCs at Sample Plot AB

\begin{tabular}{|c|c|c|c|c|c|c|c|}
\hline \multirow{2}{*}{$\begin{array}{l}\text { Sample } \\
\text { Location }\end{array}$} & \multirow{2}{*}{$\begin{array}{l}\text { Sample } \\
\text { Number }\end{array}$} & \multirow{2}{*}{$\begin{array}{c}\text { Depth } \\
\text { (cm bgs) }\end{array}$} & \multicolumn{5}{|c|}{ COPCs (pCi/g) } \\
\hline & & & Pu-238 & $\mathrm{Pu}-239 / 240$ & Sr-90 & U-234 & U-238 \\
\hline \multicolumn{3}{|c|}{ FALs } & 13 & 12.7 & 838 & 143 & 105 \\
\hline $\mathrm{AB} 1$ & 371AB01 & $0.0-5.0$ & 1.47 & 3.03 & 5.5 & 1.23 & 1.25 \\
\hline AB2 & 371AB02 & $0.0-5.0$ & 2.47 & 5.28 & 7.1 & 1.27 & 1.44 \\
\hline AB3 & 371AB03 & $0.0-5.0$ & 2.52 & 5.9 & 7.4 & 1.27 & 1.26 \\
\hline AB4 & 371AB04 & $0.0-5.0$ & 1.85 & 4.02 & 5 & 1.35 & 1.18 \\
\hline
\end{tabular}

Table F.1-7

Sample Results for Gamma-Emitting Radionuclides Detected above MDCs at Sample Plot AC

\begin{tabular}{|c|c|c|c|c|c|c|c|c|c|}
\hline \multirow{2}{*}{$\begin{array}{l}\text { Sample } \\
\text { Location }\end{array}$} & \multirow{2}{*}{$\begin{array}{l}\text { Sample } \\
\text { Number }\end{array}$} & \multirow{2}{*}{$\begin{array}{c}\text { Depth } \\
\text { (cm bgs) }\end{array}$} & \multicolumn{7}{|c|}{ COPCs (pCi/g) } \\
\hline & & & Ac-228 & Co-60 & Cs-137 & Eu-152 & $\mathrm{Pb}-212$ & $\mathrm{~Pb}-214$ & TI-208 \\
\hline \multicolumn{3}{|c|}{ FALs } & 5 & 2.68 & 12.2 & 5.67 & 5 & 5 & 5 \\
\hline $\mathrm{AC1}$ & 371AC01 & $0.0-5.0$ & 1.91 & -- & 50.7 & 0.84 & 2.2 & $1.5(\mathrm{~J})$ & 0.69 \\
\hline AC2 & 371AC02 & $0.0-5.0$ & 1.83 & -- & 51.2 & 0.96 & 2.01 & $1.54(\mathrm{~J})$ & 0.68 \\
\hline AC3 & 371AC03 & $0.0-5.0$ & 1.93 & 0.093 & 54.4 & 1.08 & 2.03 & $1.36(\mathrm{~J})$ & 0.66 \\
\hline AC4 & $371 \mathrm{AC} 04$ & $0.0-5.0$ & 1.97 & -- & 61.5 & $1.12(\mathrm{~J})$ & $2.13(\mathrm{~J})$ & $1.5(\mathrm{~J})$ & 0.65 \\
\hline
\end{tabular}

$\mathrm{J}=$ Estimated value

-- = Not detected above MDCs.

Bold indicates the values exceeding the FALs. 
Table F.1-8

Sample Results for Am-241 Detected above MDCs at Sample Plot AC

\begin{tabular}{|c|c|c|c|}
\hline \multirow{2}{*}{$\begin{array}{c}\text { Sample } \\
\text { Location }\end{array}$} & \multirow{2}{*}{$\begin{array}{c}\text { Sample } \\
\text { Number }\end{array}$} & $\begin{array}{c}\text { Depth } \\
\text { (cm bgs) }\end{array}$ & COPCs (pCi/g) \\
\cline { 4 - 4 } & & & $\mathbf{A m - 2 4 1}$ \\
\hline \hline \multicolumn{3}{|c|}{ FALs } & 12.7 \\
\hline AC1 & $371 \mathrm{AC01}$ & $0.0-5.0$ & 0.72 \\
\hline AC2 & $371 \mathrm{AC02}$ & $0.0-5.0$ & 0.92 \\
\hline AC3 & $371 \mathrm{AC03}$ & $0.0-5.0$ & 0.78 \\
\hline AC4 & 371AC04 & $0.0-5.0$ & 1.19 \\
\hline
\end{tabular}

Table F.1-9

Sample Results for Isotopes Detected above MDCs at Sample Plot AC

\begin{tabular}{|c|c|c|c|c|c|c|c|c|}
\hline \multirow{2}{*}{$\begin{array}{l}\text { Sample } \\
\text { Location }\end{array}$} & \multirow{2}{*}{$\begin{array}{l}\text { Sample } \\
\text { Number }\end{array}$} & \multirow{2}{*}{$\begin{array}{c}\text { Depth } \\
\text { (cm bgs) }\end{array}$} & \multicolumn{6}{|c|}{ COPCs (pCi/g) } \\
\hline & & & Pu-238 & $\mathrm{Pu}-239 / 240$ & Sr-90 & U-234 & U-235 & U-238 \\
\hline \multicolumn{3}{|c|}{ FALs } & 13 & 12.7 & 838 & 143 & 17.6 & 105 \\
\hline $\mathrm{AC1}$ & 371AC01 & $0.0-5.0$ & 1.71 & 3.1 & 3.4 & 1.19 & 0.116 & 1.2 \\
\hline AC2 & $371 \mathrm{AC} 02$ & $0.0-5.0$ & 2.09 & 4.43 & 2.85 & 1.15 & 0.106 & 1.1 \\
\hline AC3 & 371AC03 & $0.0-5.0$ & 1.88 & 4.14 & 2.44 & 1.35 & -- & 1.24 \\
\hline AC4 & $371 \mathrm{AC} 04$ & $0.0-5.0$ & 2.15 & 4.7 & 2.14 & 1.18 & -- & 1.2 \\
\hline
\end{tabular}

-- = Not detected above MDCs. 
Table F.1-10

Sample Results for Gamma-Emitting Radionuclides Detected above MDCs at Sample Plot AE

\begin{tabular}{|c|c|c|c|c|c|c|c|c|}
\hline \multirow{2}{*}{$\begin{array}{l}\text { Sample } \\
\text { Location }\end{array}$} & \multirow{2}{*}{$\begin{array}{l}\text { Sample } \\
\text { Number }\end{array}$} & \multirow{2}{*}{$\begin{array}{c}\text { Depth } \\
\text { (cm bgs) }\end{array}$} & \multicolumn{6}{|c|}{ COPCs (pCi/g) } \\
\hline & & & Ac-228 & Cs-137 & $\mathrm{Pb}-212$ & $\mathrm{~Pb}-214$ & TI-208 & Th-234 \\
\hline \multicolumn{3}{|c|}{ FALs } & 5 & 12.2 & 5 & 5 & 5 & 105 \\
\hline \multirow{2}{*}{ AE1 } & 371AE01 & $0.0-5.0$ & 2.02 & 13.4 & 2.21 & $1.54(\mathrm{~J})$ & 0.667 & 3.2 \\
\hline & 371AE02 & $0.0-5.0$ & 2.06 & 12.8 & 2.15 & $1.41(\mathrm{~J})$ & 0.69 & -- \\
\hline AE2 & 371AE03 & $0.0-5.0$ & 2.03 & 14.6 & 2.16 & $1.62(\mathrm{~J})$ & 0.657 & 3.5 \\
\hline AE3 & 371AE04 & $0.0-5.0$ & 2.09 & 15 & 2.14 & $1.57(\mathrm{~J})$ & 0.7 & 4.6 \\
\hline $\mathrm{AE} 4$ & 371AE05 & $0.0-5.0$ & 2.2 & 12.5 & 2.06 & $1.63(\mathrm{~J})$ & 0.677 & 3.1 \\
\hline
\end{tabular}

$\mathrm{J}=$ Estimated value

-- = Not detected above MDCs.

Bold indicates the values exceeding the FALs.

Table F.1-11

Sample Results for Am-241 Detected above MDCs at Sample Plot AE

\begin{tabular}{|c|c|c|c||}
\hline \multirow{2}{*}{$\begin{array}{c}\text { Sample } \\
\text { Location }\end{array}$} & $\begin{array}{c}\text { Sample } \\
\text { Number }\end{array}$ & $\begin{array}{c}\text { Depth } \\
\text { (cm bgs) }\end{array}$ & COPCs (pCi/g) \\
\cline { 4 - 4 } & & & Am-241 \\
\hline \multicolumn{3}{|c|}{ FALs } & $\mathbf{1 2 . 7}$ \\
\hline \hline AE1 & 371AE01 & $0.0-5.0$ & $0.093(\mathrm{~J})$ \\
\hline
\end{tabular}

$\mathrm{J}=$ Estimated value 
Table F.1-12

Sample Results for Isotopes Detected above

MDCs at Sample Plot AE

\begin{tabular}{|c|c|c|c|c|c|c|c|c|}
\hline \multirow{2}{*}{$\begin{array}{c}\text { Sample } \\
\text { Location }\end{array}$} & \multirow{2}{*}{$\begin{array}{l}\text { Sample } \\
\text { Number }\end{array}$} & \multirow{2}{*}{$\begin{array}{l}\text { Depth } \\
\text { (cm bgs) }\end{array}$} & \multicolumn{6}{|c|}{ COPCs (pCi/g) } \\
\hline & & & Pu-238 & Pu-239/240 & Sr-90 & U-234 & U-235 & U-238 \\
\hline \multicolumn{3}{|c|}{ FALs } & 13 & 12.7 & 838 & 143 & 17.6 & 105 \\
\hline \multirow{2}{*}{ AE1 } & 371AE01 & $0.0-5.0$ & 0.197 & $0.39(\mathrm{~J})$ & -- & 1.25 & -- & 1.18 \\
\hline & 371AE02 & $0.0-5.0$ & 0.091 & $0.248(\mathrm{~J})$ & -- & 1.15 & -- & 1.11 \\
\hline AE2 & 371AE03 & $0.0-5.0$ & 0.193 & $0.279(\mathrm{~J})$ & -- & 1.42 & -- & 1.19 \\
\hline AE3 & 371AE04 & $0.0-5.0$ & 0.098 & $0.267(\mathrm{~J})$ & -- & 1.21 & -- & 1.23 \\
\hline AE4 & 371AE05 & $0.0-5.0$ & 0.115 & $0.34(\mathrm{~J})$ & 1.43 & 1.33 & 0.06 & 1.32 \\
\hline
\end{tabular}

$\mathrm{J}=$ Estimated value

$--=$ Not detected above MDCs.

Table F.1-13

Sample Results for Gamma-Emitting Radionuclides Detected above MDCs at Sample Plot AF

\begin{tabular}{|c|c|c|c|c|c|c|c|c|c|}
\hline \multirow{2}{*}{$\begin{array}{l}\text { Sample } \\
\text { Location }\end{array}$} & \multirow{2}{*}{$\begin{array}{l}\text { Sample } \\
\text { Number }\end{array}$} & \multirow{2}{*}{$\begin{array}{l}\text { Depth } \\
\text { (cm bgs) }\end{array}$} & \multicolumn{7}{|c|}{ COPCs (pCi/g) } \\
\hline & & & Ac-228 & Cs-137 & Eu-152 & $\mathrm{Pb}-212$ & $\mathrm{~Pb}-214$ & TI-208 & Th-234 \\
\hline \multicolumn{3}{|c|}{ FALs } & 5 & 12.2 & 5.67 & 5 & 5 & 5 & 105 \\
\hline AF1 & 371AF01 & $0.0-5.0$ & 1.89 & 16.5 & -- & 2.03 & $1.55(\mathrm{~J})$ & 0.65 & -- \\
\hline AF2 & 371AF02 & $0.0-5.0$ & 1.9 & 22.7 & 0.328 & 1.92 & $1.45(\mathrm{~J})$ & 0.631 & -- \\
\hline AF3 & 371AF03 & $0.0-5.0$ & 1.85 & 13.3 & 0.33 & 2.1 & $1.51(\mathrm{~J})$ & 0.619 & 2.9 \\
\hline AF4 & 371AF04 & $0.0-5.0$ & 1.89 & 14.9 & -- & 1.92 & $1.45(\mathrm{~J})$ & 0.664 & 2.7 \\
\hline
\end{tabular}

$\mathrm{J}=$ Estimated value

-- = Not detected above MDCs.

Bold indicates the values exceeding the FALs. 
Table F.1-14

Sample Results for Am-241 Detected above MDCs at Sample Plot AF

\begin{tabular}{|c|c|c|c|}
\hline \multirow{2}{*}{$\begin{array}{c}\text { Sample } \\
\text { Location }\end{array}$} & \multirow{2}{*}{$\begin{array}{l}\text { Sample } \\
\text { Number }\end{array}$} & \multirow{2}{*}{$\begin{array}{c}\text { Depth } \\
\text { (cm bgs) }\end{array}$} & COPCs (pCi/g) \\
\hline & & & Am-241 \\
\hline \multicolumn{3}{|c|}{ FALs } & 12.7 \\
\hline AF1 & 371AF01 & $0.0-5.0$ & $0.19(\mathrm{~J})$ \\
\hline AF2 & 371AF02 & $0.0-5.0$ & $0.308(\mathrm{~J})$ \\
\hline AF3 & 371AF03 & $0.0-5.0$ & $0.096(\mathrm{~J})$ \\
\hline AF4 & 371AF04 & $0.0-5.0$ & $0.127(\mathrm{~J})$ \\
\hline
\end{tabular}

$\mathrm{J}=$ Estimated value

Table F.1-15

Sample Results for Isotopes Detected above MDCs at Sample Plot AF

\begin{tabular}{|c|c|c|c|c|c|c|c|}
\hline \multirow{2}{*}{$\begin{array}{l}\text { Sample } \\
\text { Location }\end{array}$} & \multirow{2}{*}{$\begin{array}{l}\text { Sample } \\
\text { Number }\end{array}$} & \multirow{2}{*}{$\begin{array}{c}\text { Depth } \\
\text { (cm bgs) }\end{array}$} & \multicolumn{5}{|c|}{ COPCs (pCi/g) } \\
\hline & & & Pu-238 & Pu-239/240 & U-234 & U-235 & U-238 \\
\hline \multicolumn{3}{|c|}{ FALs } & 13 & 12.7 & 143 & 17.6 & 105 \\
\hline AF1 & 371AF01 & $0.0-5.0$ & 0.33 & $0.77(\mathrm{~J})$ & 1.38 & -- & 1.28 \\
\hline AF2 & 371AF02 & $0.0-5.0$ & 0.51 & $1.38(\mathrm{~J})$ & 1.42 & -- & 1.33 \\
\hline AF3 & 371AF03 & $0.0-5.0$ & 0.262 & $0.57(\mathrm{~J})$ & 1.36 & 0.062 & 1.34 \\
\hline AF4 & 371AF04 & $0.0-5.0$ & 0.49 & $1.01(\mathrm{~J})$ & 1.23 & -- & 1.24 \\
\hline
\end{tabular}

$\mathrm{J}=$ Estimated value

-- $=$ Not detected above MDCs. 


\section{F.2.0 Composite Sample Analytical Data for Johnnie Boy}

Analytical results for gamma-emitting and isotopic radionuclide environmental samples collected at the sample plots at Johnnie Boy that were detected above MDCs are presented in the following tables. Because individual radionuclide results were not used for decisions, these results are presented in this appendix for completeness.

- $\quad$ Sample plot BA: Tables F.2-1 through F.2-3

- Sample plot BB: Tables F.2-4 through F.2-6

- Sample plot BC: Tables F.2-7 through F.2-9

- $\quad$ Sample plot BD: Tables F.2-10 through F.2-12

- Sample plot BE: Tables F.2-13 through F.2-15

- $\quad$ Sample plot BF: Tables F.2-16 through F.2-18

- $\quad$ Sample plot BG: Tables F.2-19 through F.2-21

- $\quad$ Sample plot BH: Tables F.2-22 through F.2-24

- Sample plot BK: Tables F.2-28 through F.2-30

- $\quad$ Sample plot BL: Tables F.2-31 through F.2-33

- $\quad$ Sample plot BM: Tables F.2-34 through F.2-36

- $\quad$ Sample plot BN: Tables F.2-37 and F.2-38 (no analytical results for Am-241 in environmental samples collected at Plot BN exceeded MDCs)

- $\quad$ Sample plot BP: Tables F.2-39 through F.2-41 
Table F.2-1

Sample Results for Gamma-Emitting Radionuclides Detected above MDCs at Sample Plot BA

\begin{tabular}{|c|c|c|c|c|c|c|c|c|c|c|c|}
\hline \multirow{2}{*}{$\begin{array}{l}\text { Sample } \\
\text { Location }\end{array}$} & \multirow{2}{*}{$\begin{array}{l}\text { Sample } \\
\text { Number }\end{array}$} & \multirow{2}{*}{$\begin{array}{c}\text { Depth } \\
\text { (cm bgs) }\end{array}$} & \multicolumn{9}{|c|}{ cOPCs (pCi/g) } \\
\hline & & & Ac-228 & Co-60 & Cs-137 & Eu-152 & Eu-154 & $\mathrm{Pb}-212$ & $\mathrm{~Pb}-214$ & TI-208 & Th-234 \\
\hline \multicolumn{3}{|c|}{ FALs } & 5 & 2.68 & 12.2 & 5.67 & 5.4 & 5 & 5 & 5 & 105 \\
\hline \multirow{2}{*}{ BA1 } & 371BA01 & $0.0-5.0$ & 2.14 & 0.8 & 17.1 & 7.29 & 1.27 & 2.1 & $1.2(\mathrm{~J})$ & 0.69 & -- \\
\hline & 371BA02 & $0.0-5.0$ & 1.94 & 0.78 & 16.7 & 7.52 & 1.09 & 2.2 & $1.2(\mathrm{~J})$ & 0.66 & -- \\
\hline BA2 & 371BA03 & $0.0-5.0$ & 2.02 & 0.94 & 18.3 & $7.9(\mathrm{~J})$ & $1.31(\mathrm{~J})$ & $2.3(\mathrm{~J})$ & $1.31(\mathrm{~J})$ & 0.69 & -- \\
\hline BA3 & 371BA04 & $0.0-5.0$ & 2.15 & 0.555 & 11.8 & 5.2 & 0.88 & 2.04 & $1.17(\mathrm{~J})$ & 0.65 & -- \\
\hline BA4 & 371BA05 & $0.0-5.0$ & 2.09 & 0.69 & 14.1 & $6.33(\mathrm{~J})$ & $0.87(\mathrm{~J})$ & $2.1(\mathrm{~J})$ & $1.17(\mathrm{~J})$ & 0.64 & 3.9 \\
\hline
\end{tabular}

$\mathrm{J}=$ Estimated value

-- = Not detected above MDCs.

Table F.2-2

Sample Results for Am-241 Detected above MDCs at Sample Plot BA

\begin{tabular}{|c|c|c|c|}
\hline \multirow{2}{*}{$\begin{array}{c}\text { Sample } \\
\text { Location }\end{array}$} & \multirow{2}{*}{$\begin{array}{c}\text { Sample } \\
\text { Number }\end{array}$} & $\begin{array}{c}\text { Depth } \\
\text { (cm bgs })\end{array}$ & Am-241 \\
\cline { 4 - 5 } & & & $\mathbf{1 2 . 7}$ \\
\hline \hline \multicolumn{3}{|c|}{ FALs } & 0.082 \\
\hline BA1 & 371 BA02 & $0.0-5.0$ & 0.044 \\
\hline BA2 & 371 BA03 & $0.0-5.0$ & 0.077 \\
\hline BA4 & 371 BA05 & $0.0-5.0$ & \\
\hline
\end{tabular}


Table F.2-3

Sample Results for Isotopes Detected above MDCs at Sample Plot BA

\begin{tabular}{|c|c|c|c|c|c|c|c|c|}
\hline \multirow{2}{*}{$\begin{array}{l}\text { Sample } \\
\text { Location }\end{array}$} & \multirow{2}{*}{$\begin{array}{l}\text { Sample } \\
\text { Number }\end{array}$} & \multirow{2}{*}{$\begin{array}{l}\text { Depth } \\
\text { (cm bgs) }\end{array}$} & \multicolumn{6}{|c|}{ COPCs (pCi/g) } \\
\hline & & & Pu-238 & Pu-239/240 & Sr-90 & U-234 & U-235 & U-238 \\
\hline \multicolumn{3}{|c|}{ FALs } & 13 & 12.7 & 838 & 143 & 17.6 & 105 \\
\hline \multirow{2}{*}{ BA1 } & 371BA01 & $0.0-5.0$ & -- & $0.55(\mathrm{~J})$ & 1.61 & $6.4(\mathrm{~J})$ & 0.208 & 0.94 \\
\hline & 371BA02 & $0.0-5.0$ & 0.175 & $0.92(\mathrm{~J})$ & 1.61 & $5.49(\mathrm{~J})$ & 0.184 & 1.05 \\
\hline BA2 & 371BA03 & $0.0-5.0$ & -- & $0.37(\mathrm{~J})$ & -- & $3.1(\mathrm{~J})$ & 0.16 & 1.07 \\
\hline BA3 & 371BA04 & $0.0-5.0$ & -- & $0.44(\mathrm{~J})$ & -- & $3.32(\mathrm{~J})$ & 0.124 & 1.04 \\
\hline BA4 & 371BA05 & $0.0-5.0$ & -- & $0.36(\mathrm{~J})$ & -- & $2.91(\mathrm{~J})$ & 0.149 & 0.94 \\
\hline
\end{tabular}

$\mathrm{J}=$ Estimated value

$--=$ Not detected above MDCs.

Table F.2-4

Sample Results for Gamma-Emitting Radionuclides Detected above MDCs at Sample Plot BB

\begin{tabular}{|c|c|c|c|c|c|c|c|c|c|c|c|}
\hline \multirow{2}{*}{$\begin{array}{l}\text { Sample } \\
\text { Location }\end{array}$} & \multirow{2}{*}{$\begin{array}{l}\text { Sample } \\
\text { Number }\end{array}$} & \multirow{2}{*}{$\begin{array}{c}\text { Depth } \\
\text { (cm bgs) }\end{array}$} & \multicolumn{9}{|c|}{ COPCs (pCi/g) } \\
\hline & & & Ac-228 & Co-60 & Cs-137 & Eu-152 & Eu-154 & $\mathrm{Pb}-212$ & $\mathrm{~Pb}-214$ & TI-208 & Th-234 \\
\hline \multicolumn{3}{|c|}{ FALs } & 5 & 2.68 & 12.2 & 5.67 & 5.4 & 5 & 5 & 5 & 105 \\
\hline BB1 & 371BB01 & $0.0-5.0$ & 2.07 & 0.414 & 9.6 & $4.53(\mathrm{~J})$ & $0.68(\mathrm{~J})$ & $2.18(\mathrm{~J})$ & $1.2(\mathrm{~J})$ & 0.68 & -- \\
\hline BB2 & 371BB02 & $0.0-5.0$ & 2.15 & 0.565 & 13.8 & 6.44 & 1.02 & 2.24 & $1.25(\mathrm{~J})$ & 0.77 & -- \\
\hline BB3 & 371BВ03 & $0.0-5.0$ & 2.15 & 0.399 & 11.6 & 5.1 & 0.69 & 2.1 & $1.3(\mathrm{~J})$ & 0.68 & -- \\
\hline BB4 & 371BB04 & $0.0-5.0$ & 2.14 & 0.405 & 10.6 & 4.65 & 0.74 & 2.25 & $1.34(\mathrm{~J})$ & 0.73 & 4 \\
\hline
\end{tabular}

$\mathrm{J}=$ Estimated value

-- = Not detected above MDCs.

Table F.2-5

Sample Results for Am-241 Detected above MDCs at Sample Plot BB

\begin{tabular}{|c|c|c|c|}
\hline \multirow{2}{*}{$\begin{array}{l}\text { Sample } \\
\text { Location }\end{array}$} & \multirow{2}{*}{$\begin{array}{l}\text { Sample } \\
\text { Number }\end{array}$} & \multirow{2}{*}{$\begin{array}{c}\text { Depth } \\
\text { (cm bgs) }\end{array}$} & COPCs (pCi/g) \\
\hline & & & Am-241 \\
\hline \multicolumn{3}{|c|}{ FALs } & 12.7 \\
\hline BB4 & 371BB04 & $0.0-5.0$ & 0.331 \\
\hline
\end{tabular}


Table F.2-6

Sample Results for Isotopes Detected above MDCs at Sample Plot BB

\begin{tabular}{|c|c|c|c|c|c|c|c|}
\hline \multirow{2}{*}{$\begin{array}{l}\text { Sample } \\
\text { Location }\end{array}$} & \multirow{2}{*}{$\begin{array}{l}\text { Sample } \\
\text { Number }\end{array}$} & \multirow{2}{*}{$\begin{array}{c}\text { Depth } \\
\text { (cm bgs) }\end{array}$} & \multicolumn{5}{|c|}{ COPCs (pCi/g) } \\
\hline & & & Pu-238 & $\mathrm{Pu}-239 / 240$ & U-234 & U-235 & U-238 \\
\hline \multicolumn{3}{|c|}{ FALs } & 13 & 12.7 & 143 & 17.6 & 105 \\
\hline BB1 & 371BВ01 & $0.0-5.0$ & -- & $0.36(\mathrm{~J})$ & $3.75(\mathrm{~J})$ & 0.135 & 1.02 \\
\hline BB2 & 371BВ02 & $0.0-5.0$ & 0.069 & $0.71(\mathrm{~J})$ & $7.6(\mathrm{~J})$ & 0.252 & 1.11 \\
\hline BB3 & 371ВВ03 & $0.0-5.0$ & 0.073 & $0.33(\mathrm{~J})$ & $1.65(\mathrm{~J})$ & -- & 1.13 \\
\hline BB4 & 371BВ04 & $0.0-5.0$ & 0.219 & $2.16(\mathrm{~J})$ & $2.11(\mathrm{~J})$ & -- & 1.11 \\
\hline
\end{tabular}

$\mathrm{J}=$ Estimated value

-- = Not detected above MDCs.

Table F.2-7

Sample Results for Gamma-Emitting Radionuclides Detected above MDCs at Sample Plot BC

\begin{tabular}{|c|c|c|c|c|c|c|c|c|c|c|}
\hline \multirow{2}{*}{$\begin{array}{l}\text { Sample } \\
\text { Location }\end{array}$} & \multirow{2}{*}{$\begin{array}{l}\text { Sample } \\
\text { Number }\end{array}$} & \multirow{2}{*}{$\begin{array}{l}\text { Depth } \\
\text { (cm bgs) }\end{array}$} & \multicolumn{8}{|c|}{ COPCs (pCi/g) } \\
\hline & & & Ac-228 & Co-60 & Cs-137 & Eu-152 & Eu-154 & $\mathrm{Pb}-212$ & $\mathrm{~Pb}-214$ & TI-208 \\
\hline \multicolumn{3}{|c|}{ FALs } & 5 & 2.68 & 12.2 & 5.67 & 5.4 & 5 & 5 & 5 \\
\hline $\mathrm{BC} 1$ & 371BC01 & $0.0-5.0$ & 2.05 & 0.646 & 16.7 & 7.46 & 1.12 & 2.29 & $1.18(\mathrm{~J})$ & 0.69 \\
\hline $\mathrm{BC} 2$ & 371BC02 & $0.0-5.0$ & 2.2 & 0.478 & 14 & 6.87 & 0.97 & 2.35 & $1.29(\mathrm{~J})$ & 0.73 \\
\hline BC3 & 371BC03 & $0.0-5.0$ & 2.17 & 0.672 & 17.3 & 8.4 & 1.25 & 2.47 & $1.15(\mathrm{~J})$ & 0.78 \\
\hline BC4 & 371BC04 & $0.0-5.0$ & 2.12 & 0.5 & 13.2 & 5.85 & 0.74 & 2.24 & $1.27(\mathrm{~J})$ & 0.65 \\
\hline
\end{tabular}

$\mathrm{J}=$ Estimated value

Bold indicates the values exceeding the FALs. 
Table F.2-8

Sample Results for Am-241 Detected above MDCs at Sample Plot BC

\begin{tabular}{|c|c|c|c|}
\hline \multirow{2}{*}{$\begin{array}{l}\text { Sample } \\
\text { Location }\end{array}$} & \multirow{2}{*}{$\begin{array}{l}\text { Sample } \\
\text { Number }\end{array}$} & \multirow{2}{*}{$\begin{array}{c}\text { Depth } \\
\text { (cm bgs) }\end{array}$} & COPCs (pCi/g) \\
\hline & & & Am-241 \\
\hline \multicolumn{3}{|c|}{ FALs } & 12.7 \\
\hline $\mathrm{BC} 1$ & 371BC01 & $0.0-5.0$ & 0.96 \\
\hline $\mathrm{BC} 2$ & 371BC02 & $0.0-5.0$ & 0.101 \\
\hline BC3 & 371BC03 & $0.0-5.0$ & 0.214 \\
\hline
\end{tabular}

Table F.2-9

Sample Results for Isotopes Detected above MDCs at Sample Plot BC

\begin{tabular}{|c|c|c|c|c|c|c|c|c|}
\hline \multirow{2}{*}{$\begin{array}{l}\text { Sample } \\
\text { Location }\end{array}$} & \multirow{2}{*}{$\begin{array}{l}\text { Sample } \\
\text { Number }\end{array}$} & \multirow{2}{*}{$\begin{array}{c}\text { Depth } \\
\text { (cm bgs) }\end{array}$} & \multicolumn{6}{|c|}{ COPCs (pCi/g) } \\
\hline & & & Pu-238 & Pu-239/240 & Sr-90 & U-234 & U-235 & U-238 \\
\hline \multicolumn{3}{|c|}{ FALs } & 13 & 12.7 & 838 & 143 & 17.6 & 105 \\
\hline BC1 & 371BC01 & $0.0-5.0$ & 0.171 & $6.8(\mathrm{~J})$ & 2.39 & $7.1(\mathrm{~J})$ & 0.193 & 0.81 \\
\hline $\mathrm{BC} 2$ & 371BC02 & $0.0-5.0$ & 0.124 & $0.74(\mathrm{~J})$ & -- & $2.91(\mathrm{~J})$ & 0.143 & 1.01 \\
\hline BC3 & 371BC03 & $0.0-5.0$ & 0.3 & $1.31(\mathrm{~J})$ & 1.22 & $4.04(\mathrm{~J})$ & 0.188 & 0.78 \\
\hline BC4 & 371BC04 & $0.0-5.0$ & -- & $0.36(\mathrm{~J})$ & -- & $5.01(\mathrm{~J})$ & 0.21 & 0.97 \\
\hline
\end{tabular}

$\mathrm{J}=$ Estimated value

-- $=$ Not detected above MDCs. 
Table F.2-10

\section{Sample Results for Gamma-Emitting Radionuclides Detected above MDCs at Sample Plot BD}

\begin{tabular}{|c|c|c|c|c|c|c|c|c|c|c|c|}
\hline \multirow{2}{*}{$\begin{array}{l}\text { Sample } \\
\text { Location }\end{array}$} & \multirow{2}{*}{$\begin{array}{l}\text { Sample } \\
\text { Number }\end{array}$} & \multirow{2}{*}{$\begin{array}{c}\text { Depth } \\
\text { (cm bgs) }\end{array}$} & \multicolumn{9}{|c|}{ COPCs (pCi/g) } \\
\hline & & & Ac-228 & Co-60 & Cs-137 & Eu-152 & Eu-154 & $\mathrm{Pb}-212$ & $\mathrm{~Pb}-214$ & Tl-208 & Th-234 \\
\hline \multicolumn{3}{|c|}{ FALs } & 5 & 2.68 & 12.2 & 5.67 & 5.4 & 5 & 5 & 5 & 105 \\
\hline BD1 & 371BD01 & $0.0-5.0$ & 2.24 & 0.398 & 11.7 & $5.35(\mathrm{~J})$ & $0.75(\mathrm{~J})$ & $2.39(\mathrm{~J})$ & $1.37(\mathrm{~J})$ & 0.73 & -- \\
\hline BD2 & 371BD02 & $0.0-5.0$ & 2.13 & 0.366 & 11.1 & $4.63(\mathrm{~J})$ & $0.93(\mathrm{~J})$ & $2(\mathrm{~J})$ & $1.22(\mathrm{~J})$ & 0.64 & -- \\
\hline BD3 & 371BD03 & $0.0-5.0$ & 2.08 & 0.42 & 11.2 & 5.06 & 1.02 & 2.33 & $1.31(\mathrm{~J})$ & 0.7 & -- \\
\hline BD4 & 371BD04 & $0.0-5.0$ & 2 & 0.437 & 13.3 & 5.68 & 0.77 & 2.25 & $1.3(\mathrm{~J})$ & 0.72 & 4.8 \\
\hline
\end{tabular}

$\mathrm{J}=$ Estimated value

$--=$ Not detected above MDCs.

Table F.2-11

Sample Results for Am-241 Detected above MDCs at Sample Plot BD

\begin{tabular}{||c|c|c|c||}
\hline \multirow{2}{*}{$\begin{array}{c}\text { Sample } \\
\text { Location }\end{array}$} & \multirow{2}{*}{$\begin{array}{c}\text { Sample } \\
\text { Number }\end{array}$} & $\begin{array}{c}\text { Depth } \\
\text { (cm bgs) }\end{array}$ & COPCs (pCi/g) \\
\cline { 4 - 5 } & & & Am-241 \\
\hline \multicolumn{3}{|c|}{ FALs } & $\mathbf{1 2 . 7}$ \\
\hline \hline BD1 & 371 BD01 & $0.0-5.0$ & 0.201 \\
\hline BD3 & 371 BD03 & $0.0-5.0$ & 0.127 \\
\hline BD4 & 371 BD04 & $0.0-5.0$ & 0.078 \\
\hline
\end{tabular}


Table F.2-12

Sample Results for Isotopes Detected above MDCs at Sample Plot BD

\begin{tabular}{|c|c|c|c|c|c|c|c|c|}
\hline \multirow{2}{*}{$\begin{array}{l}\text { Sample } \\
\text { Location }\end{array}$} & \multirow{2}{*}{$\begin{array}{l}\text { Sample } \\
\text { Number }\end{array}$} & \multirow{2}{*}{$\begin{array}{c}\text { Depth } \\
\text { (cm bgs) }\end{array}$} & \multicolumn{6}{|c|}{ COPCs (pCi/g) } \\
\hline & & & Pu-238 & Pu-239/240 & Sr-90 & U-234 & U-235 & U-238 \\
\hline \multicolumn{3}{|c|}{ FALs } & 13 & 12.7 & 838 & 143 & 17.6 & 105 \\
\hline BD1 & 371BD01 & $0.0-5.0$ & 0.187 & $0.98(\mathrm{~J})$ & -- & $3.34(\mathrm{~J})$ & 0.104 & 1.1 \\
\hline BD2 & 371BD02 & $0.0-5.0$ & -- & $0.73(\mathrm{~J})$ & 1.22 & $5.8(\mathrm{~J})$ & 0.231 & 0.95 \\
\hline BD3 & 371BD03 & $0.0-5.0$ & 0.215 & $1.04(\mathrm{~J})$ & -- & $5.7(\mathrm{~J})$ & 0.236 & 1 \\
\hline BD4 & 371BD04 & $0.0-5.0$ & 0.2 & $0.72(\mathrm{~J})$ & -- & $2.02(\mathrm{~J})$ & 0.083 & 0.98 \\
\hline
\end{tabular}

$\mathrm{J}=$ Estimated value

-- = Not detected above MDCs.

Table F.2-13

Sample Results for Gamma-Emitting Radionuclides Detected above MDCs at Sample Plot BE

\begin{tabular}{|c|c|c|c|c|c|c|c|c|c|c|}
\hline \multirow{2}{*}{$\begin{array}{l}\text { Sample } \\
\text { Location }\end{array}$} & \multirow{2}{*}{$\begin{array}{l}\text { Sample } \\
\text { Number }\end{array}$} & \multirow{2}{*}{$\begin{array}{c}\text { Depth } \\
\text { (cm bgs) }\end{array}$} & \multicolumn{8}{|c|}{ COPCs (pCi/g) } \\
\hline & & & Ac-228 & Co-60 & Cs-137 & Eu-152 & Eu-154 & $\mathrm{Pb}-212$ & $\mathrm{~Pb}-214$ & TI-208 \\
\hline \multicolumn{3}{|c|}{ FALs } & 5 & 2.68 & 12.2 & 5.67 & 5.4 & 5 & 5 & 5 \\
\hline BE1 & 371BE01 & $0.0-5.0$ & 2.35 & 1.15 & 30.2 & 13.5 & 2.03 & 2.37 & $1.15(\mathrm{~J})$ & 0.71 \\
\hline BE2 & 371BE02 & $0.0-5.0$ & 2.23 & 1.45 & 32.8 & 16.4 & 2.57 & 2 & $1.25(\mathrm{~J})$ & 0.68 \\
\hline BE3 & 371BE03 & $0.0-5.0$ & 2.17 & 1 & 23.8 & 12 & 1.89 & 2.27 & $1.24(\mathrm{~J})$ & 0.7 \\
\hline BE4 & 371BE04 & $0.0-5.0$ & 2.07 & 1.25 & 31.3 & 14.6 & 2.24 & 2.44 & $1.22(\mathrm{~J})$ & 0.72 \\
\hline
\end{tabular}

$\mathrm{J}=$ Estimated value

Bold indicates the values exceeding the FALs. 
Table F.2-14

Sample Results for Am-241 Detected above MDCs at Sample Plot BE

\begin{tabular}{|c|c|c|c|}
\hline \multirow{2}{*}{$\begin{array}{c}\text { Sample } \\
\text { Location }\end{array}$} & \multirow{2}{*}{$\begin{array}{l}\text { Sample } \\
\text { Number }\end{array}$} & \multirow{2}{*}{$\begin{array}{c}\text { Depth } \\
\text { (cm bgs) }\end{array}$} & COPCs (pCi/g) \\
\hline & & & Am-241 \\
\hline \multicolumn{3}{|c|}{ FALs } & 12.7 \\
\hline BE1 & 371BE01 & $0.0-5.0$ & 0.349 \\
\hline BE2 & 371BE02 & $0.0-5.0$ & 0.071 \\
\hline BE3 & 371BE03 & $0.0-5.0$ & 0.089 \\
\hline BE4 & 371BE04 & $0.0-5.0$ & 0.284 \\
\hline
\end{tabular}

Table F.2-15

Sample Results for Isotopes Detected above MDCs at Sample Plot BE

\begin{tabular}{|c|c|c|c|c|c|c|c|c|}
\hline \multirow{2}{*}{$\begin{array}{l}\text { Sample } \\
\text { Location }\end{array}$} & \multirow{2}{*}{$\begin{array}{l}\text { Sample } \\
\text { Number }\end{array}$} & \multirow{2}{*}{$\begin{array}{c}\text { Depth } \\
\text { (cm bgs) }\end{array}$} & \multicolumn{6}{|c|}{ COPCs (pCi/g) } \\
\hline & & & Pu-238 & Pu-239/240 & Sr-90 & U-234 & U-235 & U-238 \\
\hline \multicolumn{3}{|c|}{ FALs } & 13 & 12.7 & 838 & 143 & 17.6 & 105 \\
\hline BE1 & 371BE01 & $0.0-5.0$ & 0.226 & $2.38(\mathrm{~J})$ & 2.71 & 7.8 & 0.34 & 0.91 \\
\hline BE2 & 371BE02 & $0.0-5.0$ & 0.085 & $0.95(\mathrm{~J})$ & 3.08 & 15.1 & 0.48 & 1.08 \\
\hline BE3 & 371BE03 & $0.0-5.0$ & -- & $0.75(\mathrm{~J})$ & 2.4 & 6.7 & 0.33 & 0.93 \\
\hline BE4 & 371BE04 & $0.0-5.0$ & 0.273 & $1.74(\mathrm{~J})$ & 3.05 & 10.3 & 0.38 & 1.04 \\
\hline
\end{tabular}

$\mathrm{J}=$ Estimated value

-- = Not detected above MDCs. 
Table F.2-16

Sample Results for Gamma-Emitting Radionuclides Detected above MDCs at Sample Plot BF

\begin{tabular}{|c|c|c|c|c|c|c|c|c|c|c|}
\hline \multirow{2}{*}{$\begin{array}{l}\text { Sample } \\
\text { Location }\end{array}$} & \multirow{2}{*}{$\begin{array}{l}\text { Sample } \\
\text { Number }\end{array}$} & \multirow{2}{*}{$\begin{array}{c}\text { Depth } \\
\text { (cm bgs) }\end{array}$} & \multicolumn{8}{|c|}{ COPCs (pCi/g) } \\
\hline & & & Ac-228 & Co-60 & Cs-137 & Eu-152 & Eu-154 & $\mathrm{Pb}-212$ & $\mathrm{~Pb}-214$ & TI-208 \\
\hline \multicolumn{3}{|c|}{ FALs } & 5 & 2.68 & 12.2 & 5.67 & 5.4 & 5 & 5 & 5 \\
\hline BF1 & 371BF01 & $0.0-5.0$ & 1.95 & 0.157 & 6.61 & $2.69(\mathrm{~J})$ & -- & $2.08(\mathrm{~J})$ & $1.25(\mathrm{~J})$ & 0.68 \\
\hline BF2 & 371BF02 & $0.0-5.0$ & 1.96 & 0.214 & 6.89 & $2.78(\mathrm{~J})$ & -- & $2.06(\mathrm{~J})$ & $1.23(\mathrm{~J})$ & 0.66 \\
\hline BF3 & 371BF03 & $0.0-5.0$ & 2.06 & 0.177 & 7.14 & $2.95(\mathrm{~J})$ & -- & $2.09(\mathrm{~J})$ & $1.18(\mathrm{~J})$ & 0.595 \\
\hline BF4 & 371BF04 & $0.0-5.0$ & 1.98 & 0.226 & 5.76 & $2.89(\mathrm{~J})$ & $0.62(\mathrm{~J})$ & $2.15(\mathrm{~J})$ & $1.2(\mathrm{~J})$ & 0.68 \\
\hline
\end{tabular}

$\mathrm{J}=$ Estimated value

-- = Not detected above MDCs.

Table F.2-17

Sample Results for Am-241 Detected above MDCs at Sample Plot BF

\begin{tabular}{|c|c|c|c|}
\hline \multirow{2}{*}{$\begin{array}{l}\text { Sample } \\
\text { Location }\end{array}$} & \multirow{2}{*}{$\begin{array}{l}\text { Sample } \\
\text { Number }\end{array}$} & \multirow{2}{*}{$\begin{array}{c}\text { Depth } \\
\text { (cm bgs) }\end{array}$} & COPCs (pCi/g) \\
\hline & & & Am-241 \\
\hline \multicolumn{3}{|c|}{ FALs } & 12.7 \\
\hline BF1 & 371BF01 & $0.0-5.0$ & 0.103 \\
\hline BF3 & 371BF03 & $0.0-5.0$ & 0.141 \\
\hline BF4 & 371BF04 & $0.0-5.0$ & 0.126 \\
\hline
\end{tabular}


Table F.2-18

Sample Results for Isotopes Detected above MDCs at Sample Plot BF

\begin{tabular}{|c|c|c|c|c|c|c|c|c|}
\hline \multirow{2}{*}{$\begin{array}{l}\text { Sample } \\
\text { Location }\end{array}$} & \multirow{2}{*}{$\begin{array}{l}\text { Sample } \\
\text { Number }\end{array}$} & \multirow{2}{*}{$\begin{array}{c}\text { Depth } \\
\text { (cm bgs) }\end{array}$} & \multicolumn{6}{|c|}{ COPCs (pCi/g) } \\
\hline & & & Pu-238 & Pu-239/240 & Sr-90 & U-234 & U-235 & U-238 \\
\hline \multicolumn{3}{|c|}{ FALs } & 13 & 12.7 & 838 & 143 & 17.6 & 105 \\
\hline BF1 & 371BF01 & $0.0-5.0$ & 0.084 & $0.78(\mathrm{~J})$ & 1.23 & $6.1(\mathrm{~J})$ & 0.215 & 1.08 \\
\hline BF2 & 371BF02 & $0.0-5.0$ & -- & $0.33(\mathrm{~J})$ & 1.43 & 1.52 & -- & 1.09 \\
\hline BF3 & 371BF03 & $0.0-5.0$ & -- & $0.94(\mathrm{~J})$ & 1.86 & 1.98 & -- & 1.09 \\
\hline BF4 & 371BF04 & $0.0-5.0$ & 0.113 & $0.71(\mathrm{~J})$ & 1.3 & 1.49 & -- & 0.95 \\
\hline
\end{tabular}

$\mathrm{J}=$ Estimated value

-- = Not detected above MDCs.

Table F.2-19

Sample Results for Gamma-Emitting Radionuclides Detected above MDCs at Sample Plot BG

\begin{tabular}{|c|c|c|c|c|c|c|c|c|c|c|}
\hline \multirow{2}{*}{$\begin{array}{l}\text { Sample } \\
\text { Location }\end{array}$} & \multirow{2}{*}{$\begin{array}{l}\text { Sample } \\
\text { Number }\end{array}$} & \multirow{2}{*}{$\begin{array}{c}\text { Depth } \\
\text { (cm bgs) }\end{array}$} & \multicolumn{8}{|c|}{ COPCs (pCi/g) } \\
\hline & & & Ac-228 & Co-60 & Cs-137 & Eu-152 & $\mathrm{Pb}-212$ & $\mathrm{~Pb}-214$ & TI-208 & Th-234 \\
\hline \multicolumn{3}{|c|}{ FALs } & 5 & 2.68 & 12.2 & 5.67 & 5 & 5 & 5 & 105 \\
\hline BG1 & 371BG01 & $0.0-5.0$ & 2.21 & -- & 4.68 & $1.96(\mathrm{~J})$ & $2.21(\mathrm{~J})$ & $1.16(\mathrm{~J})$ & 0.661 & -- \\
\hline BG2 & 371BG02 & $0.0-5.0$ & 2.27 & 0.106 & 6 & $2(\mathrm{~J})$ & $2.38(\mathrm{~J})$ & $1.35(\mathrm{~J})$ & 0.64 & -- \\
\hline BG3 & 371BG03 & $0.0-5.0$ & 2.15 & -- & 4.78 & $1.82(\mathrm{~J})$ & $2.21(\mathrm{~J})$ & $1.27(\mathrm{~J})$ & 0.69 & -- \\
\hline BG4 & 371BG04 & $0.0-5.0$ & 2.1 & -- & 5.31 & $2.02(\mathrm{~J})$ & $2.18(\mathrm{~J})$ & $1.17(\mathrm{~J})$ & 0.627 & $3.1(\mathrm{~J})$ \\
\hline
\end{tabular}

$\mathrm{J}=$ Estimated value

$--=$ Not detected above MDCs.

Table F.2-20

Sample Results for Am-241 Detected above MDCs at Sample Plot BG

\begin{tabular}{|c|c|c|c|}
\hline \multirow{2}{*}{$\begin{array}{c}\text { Sample } \\
\text { Location }\end{array}$} & $\begin{array}{c}\text { Sample } \\
\text { Number }\end{array}$ & $\begin{array}{c}\text { Depth (cm } \\
\text { bgs) }\end{array}$ & Am-241 \\
\cline { 4 - 4 } & & & 12.7 \\
\hline \hline \multicolumn{3}{|c|}{ FALs } & COPCs (pCi/g) \\
\hline BG1 & 371BG01 & $0.0-5.0$ & 0.106 \\
\hline
\end{tabular}


Table F.2-21

Sample Results for Isotopes Detected above MDCs at Sample Plot BG

\begin{tabular}{|c|c|c|c|c|c|c|c|c|}
\hline \multirow{2}{*}{$\begin{array}{l}\text { Sample } \\
\text { Location }\end{array}$} & \multirow{2}{*}{$\begin{array}{l}\text { Sample } \\
\text { Number }\end{array}$} & \multirow{2}{*}{$\begin{array}{c}\text { Depth } \\
\text { (cm bgs) }\end{array}$} & \multicolumn{6}{|c|}{ COPCs (pCi/g) } \\
\hline & & & Pu-238 & $\mathrm{Pu}-239 / 240$ & Sr-90 & U-234 & U-235 & U-238 \\
\hline \multicolumn{3}{|c|}{ FALs } & 13 & 12.7 & 838 & 143 & 17.6 & 105 \\
\hline BG1 & 371BG01 & $0.0-5.0$ & 0.241 & $0.94(\mathrm{~J})$ & 1.82 & 1.26 & -- & 0.91 \\
\hline BG2 & 371BG02 & $0.0-5.0$ & 0.147 & $0.58(\mathrm{~J})$ & -- & 1.75 & 0.073 & 1.01 \\
\hline BG3 & 371BG03 & $0.0-5.0$ & 0.094 & $0.58(\mathrm{~J})$ & 1.33 & 1.39 & -- & 0.94 \\
\hline BG4 & 371BG04 & $0.0-5.0$ & -- & $0.48(\mathrm{~J})$ & 1.69 & 3.88 & 0.133 & 0.98 \\
\hline
\end{tabular}

$\mathrm{J}=$ Estimated value

-- = Not detected above MDCs.

Table F.2-22

Sample Results for Gamma-Emitting Radionuclides Detected above MDCs at Sample Plot BH

\begin{tabular}{|c|c|c|c|c|c|c|c|c|c|}
\hline \multirow{2}{*}{$\begin{array}{l}\text { Sample } \\
\text { Location }\end{array}$} & \multirow{2}{*}{$\begin{array}{l}\text { Sample } \\
\text { Number }\end{array}$} & \multirow{2}{*}{$\begin{array}{c}\text { Depth } \\
\text { (cm bgs) }\end{array}$} & \multicolumn{7}{|c|}{ COPCs (pCi/g) } \\
\hline & & & Ac-228 & Cs-137 & Eu-152 & $\mathrm{Pb}-212$ & $\mathrm{~Pb}-214$ & TI-208 & Th-234 \\
\hline \multicolumn{3}{|c|}{ FALs } & 5 & 12.2 & 5.67 & 5 & 5 & 5 & 105 \\
\hline $\mathrm{BH} 1$ & 371BH01 & $0.0-5.0$ & 2 & 0.67 & -- & $2.27(\mathrm{~J})$ & $1.35(\mathrm{~J})$ & 0.68 & $3.5(\mathrm{~J})$ \\
\hline \multirow{2}{*}{$\mathrm{BH} 2$} & 371BH02 & $0.0-5.0$ & 2.11 & 0.89 & $0.276(\mathrm{~J})$ & $2.16(\mathrm{~J})$ & $1.13(\mathrm{~J})$ & 0.68 & $2.9(\mathrm{~J})$ \\
\hline & 371BH03 & $0.0-5.0$ & 2.03 & 0.75 & $0.296(\mathrm{~J})$ & $2.09(\mathrm{~J})$ & $1.11(\mathrm{~J})$ & 0.69 & $3.23(\mathrm{~J})$ \\
\hline $\mathrm{BH} 3$ & 371BH04 & $0.0-5.0$ & 2.07 & 0.607 & $0.242(\mathrm{~J})$ & $2.18(\mathrm{~J})$ & $1.15(\mathrm{~J})$ & 0.666 & $2.9(\mathrm{~J})$ \\
\hline $\mathrm{BH} 4$ & 371BH05 & $0.0-5.0$ & 2.08 & 0.605 & $0.31(\mathrm{~J})$ & $2.03(\mathrm{~J})$ & $1.09(\mathrm{~J})$ & 0.628 & $2.5(\mathrm{~J})$ \\
\hline
\end{tabular}

$\mathrm{J}=$ Estimated value

-- = Not detected above MDCs. 
Table F.2-23

Sample Results for Am-241 Detected above MDCs at Sample Plot BH

\begin{tabular}{|c|c|c|c|}
\hline \multirow{2}{*}{$\begin{array}{l}\text { Sample } \\
\text { Location }\end{array}$} & \multirow{2}{*}{$\begin{array}{l}\text { Sample } \\
\text { Number }\end{array}$} & \multirow{2}{*}{$\begin{array}{c}\text { Depth } \\
\text { (cm bgs) }\end{array}$} & COPCs (pCi/g) \\
\hline & & & Am-241 \\
\hline \multicolumn{3}{|c|}{ FALs } & 12.7 \\
\hline $\mathrm{BH} 3$ & 371BH04 & $0.0-5.0$ & 0.098 \\
\hline $\mathrm{BH} 4$ & 371BH05 & $0.0-5.0$ & 0.098 \\
\hline
\end{tabular}

Table F.2-24

Sample Results for Isotopes Detected above MDCs at Sample Plot BH

\begin{tabular}{|c|c|c|c|c|c|c|c|}
\hline \multirow{2}{*}{$\begin{array}{l}\text { Sample } \\
\text { Location }\end{array}$} & \multirow{2}{*}{$\begin{array}{l}\text { Sample } \\
\text { Number }\end{array}$} & \multirow{2}{*}{$\begin{array}{c}\text { Depth } \\
\text { (cm bgs) }\end{array}$} & \multicolumn{5}{|c|}{ COPCs (pCi/g) } \\
\hline & & & Pu-238 & Pu-239/240 & U-234 & U-235 & U-238 \\
\hline \multicolumn{3}{|c|}{ FALs } & 13 & 12.7 & 143 & 17.6 & 105 \\
\hline $\mathrm{BH} 1$ & 371BH01 & $0.0-5.0$ & -- & $0.32(\mathrm{~J})$ & 0.84 & 0.084 & 0.84 \\
\hline \multirow{2}{*}{$\mathrm{BH} 2$} & 371BH02 & $0.0-5.0$ & 0.066 & $0.51(\mathrm{~J})$ & 1.03 & -- & 0.89 \\
\hline & 371BН03 & $0.0-5.0$ & -- & $0.45(\mathrm{~J})$ & 0.97 & -- & 0.9 \\
\hline $\mathrm{BH} 3$ & 371BH04 & $0.0-5.0$ & 0.149 & $0.83(\mathrm{~J})$ & 0.9 & -- & 0.98 \\
\hline $\mathrm{BH} 4$ & 371BH05 & $0.0-5.0$ & 0.064 & $0.49(\mathrm{~J})$ & 0.91 & -- & 0.83 \\
\hline
\end{tabular}

$\mathrm{J}=$ Estimated value

-- = Not detected above MDCs. 
Table F.2-25

Sample Results for Gamma-Emitting Radionuclides Detected above MDCs at Sample Plot BJ

\begin{tabular}{|c|c|c|c|c|c|c|c|c|c|c|}
\hline \multirow{2}{*}{$\begin{array}{c}\text { Sample } \\
\text { Location }\end{array}$} & \multirow{2}{*}{$\begin{array}{l}\text { Sample } \\
\text { Number }\end{array}$} & \multirow{2}{*}{$\begin{array}{l}\text { Depth } \\
\text { (cm bgs) }\end{array}$} & \multicolumn{8}{|c|}{ COPCs (pCi/g) } \\
\hline & & & Ac-228 & Co-60 & Cs-137 & Eu-152 & Eu-154 & $\mathrm{Pb}-212$ & $\mathrm{~Pb}-214$ & TI-208 \\
\hline \multicolumn{3}{|c|}{ FALs } & 5 & 2.68 & 12.2 & 5.67 & 5.4 & 5 & 5 & 5 \\
\hline BJ1 & 371BJ01 & $0.0-5.0$ & 2.37 & 1.3 & 32.8 & 14.6 & 2.42 & 2.39 & $1.04(\mathrm{~J})$ & 0.79 \\
\hline BJ2 & 371BJ02 & $0.0-5.0$ & 2.21 & 1.37 & 35.5 & 15.4 & 2.53 & 2.08 & $1.22(\mathrm{~J})$ & 0.68 \\
\hline BJ3 & 371BJ03 & $0.0-5.0$ & 2.25 & 0.94 & 24.7 & 10.3 & 1.69 & 2.31 & $1.3(\mathrm{~J})$ & 0.77 \\
\hline BJ4 & 371BJ04 & $0.0-5.0$ & 2.32 & 1.26 & 34.3 & 15.1 & 2.5 & 2.14 & $1.25(\mathrm{~J})$ & 0.74 \\
\hline
\end{tabular}

$\mathrm{J}=$ Estimated value

Bold indicates the values exceeding the FALs.

Table F.2-26

Sample Results for Am-241 Detected above MDCs at Sample Plot BJ

\begin{tabular}{|c|c|c|c|}
\hline \multirow{2}{*}{$\begin{array}{c}\text { Sample } \\
\text { Location }\end{array}$} & \multirow{2}{*}{$\begin{array}{c}\text { Sample } \\
\text { Number }\end{array}$} & $\begin{array}{c}\text { Depth } \\
\text { (cm bgs) }\end{array}$ & COPCs (pCi/g) \\
\cline { 4 - 4 } & & & $\mathbf{A m - 2 4 1}$ \\
\hline \multicolumn{3}{|c|}{ FALs } & $\mathbf{1 2 . 7}$ \\
\hline \hline BJ1 & 371 BJ01 & $0.0-5.0$ & $0.061(\mathrm{~J})$ \\
\hline BJ2 & 371 BJ02 & $0.0-5.0$ & $0.18(\mathrm{~J})$ \\
\hline BJ4 & 371 BJ04 & $0.0-5.0$ & $0.145(\mathrm{~J})$ \\
\hline
\end{tabular}

$\mathrm{J}=$ Estimated value 
Table F.2-27

Sample Results for Isotopes Detected above MDCs at Sample Plot BJ

\begin{tabular}{|c|c|c|c|c|c|c|c|c|}
\hline \multirow{2}{*}{$\begin{array}{l}\text { Sample } \\
\text { Location }\end{array}$} & \multirow{2}{*}{$\begin{array}{l}\text { Sample } \\
\text { Number }\end{array}$} & \multirow{2}{*}{$\begin{array}{c}\text { Depth } \\
\text { (cm bgs) }\end{array}$} & \multicolumn{6}{|c|}{ COPCs (pCi/g) } \\
\hline & & & Pu -238 & $\mathrm{Pu}-239 / 240$ & Sr -90 & U-234 & U-235 & U-238 \\
\hline BJ1 & 371BJ01 & $0.0-5.0$ & -- & $0.89(\mathrm{~J})$ & 2.54 & $14.3(\mathrm{~J})$ & $0.64(\mathrm{~J})$ & 1.04 \\
\hline $\mathrm{BJ3}$ & 371BJ03 & $0.0-5.0$ & -- & $0.54(\mathrm{~J})$ & 3.22 & $8.3(\mathrm{~J})$ & $0.46(\mathrm{~J})$ & 1.13 \\
\hline BJ4 & 371BJ04 & $0.0-5.0$ & 0.115 & $1.22(\mathrm{~J})$ & 3.24 & $10.1(\mathrm{~J})$ & $0.42(\mathrm{~J})$ & 0.95 \\
\hline
\end{tabular}

$\mathrm{J}=$ Estimated value

$--=$ Not detected above MDCs.

Table F.2-28

Sample Results for Gamma-Emitting Radionuclides Detected above MDCs at Sample Plot BK

\begin{tabular}{|c|c|c|c|c|c|c|c|c|c|c|}
\hline \multirow{2}{*}{$\begin{array}{l}\text { Sample } \\
\text { Location }\end{array}$} & \multirow{2}{*}{$\begin{array}{l}\text { Sample } \\
\text { Number }\end{array}$} & \multirow{2}{*}{$\begin{array}{c}\text { Depth } \\
\text { (cm bgs) }\end{array}$} & \multicolumn{8}{|c|}{ COPCs (pCi/g) } \\
\hline & & & Ac-228 & Co-60 & Cs-137 & Eu-152 & Eu-154 & $\mathrm{Pb}-212$ & $\mathrm{~Pb}-214$ & TI-208 \\
\hline \multicolumn{3}{|c|}{ FALs } & 5 & 2.68 & 12.2 & 5.67 & 5.4 & 5 & 5 & 5 \\
\hline BK1 & 371BK01 & $0.0-5.0$ & 2.3 & 0.596 & 17.5 & 7.66 & 1.2 & 2.32 & $1.33(\mathrm{~J})$ & 0.66 \\
\hline BK2 & 371BK02 & $0.0-5.0$ & 2.12 & 0.88 & 21.5 & 10.4 & 1.81 & 2.38 & $1.13(\mathrm{~J})$ & 0.66 \\
\hline BK3 & 371BK03 & $0.0-5.0$ & 2.33 & 0.93 & 22.6 & 10.8 & 1.67 & 2.23 & $1.06(\mathrm{~J})$ & 0.67 \\
\hline BK3 & 371BK04 & $0.0-5.0$ & 2.23 & 1 & 22.1 & 10.3 & 1.91 & 2.25 & $1.16(\mathrm{~J})$ & 0.81 \\
\hline BK4 & 371BK05 & $0.0-5.0$ & 2.29 & 0.554 & 14.9 & 7.14 & 1 & 2.33 & $1.06(\mathrm{~J})$ & 0.77 \\
\hline
\end{tabular}

$\mathrm{J}=$ Estimated value

Bold indicates the values exceeding the FALs. 
Table F.2-29

Sample Results for Am-241 Detected above MDCs at Sample Plot BK

\begin{tabular}{|c|c|c|c|}
\hline \multirow{2}{*}{$\begin{array}{l}\text { Sample } \\
\text { Location }\end{array}$} & \multirow{2}{*}{$\begin{array}{l}\text { Sample } \\
\text { Number }\end{array}$} & \multirow{2}{*}{$\begin{array}{c}\text { Depth } \\
\text { (cm bgs) }\end{array}$} & COPCs (pCi/g) \\
\hline & & & Am-241 \\
\hline \multicolumn{3}{|c|}{ FALs } & 12.7 \\
\hline BK2 & 371BK02 & $0.0-5.0$ & $0.092(\mathrm{~J})$ \\
\hline BK3 & 371BК04 & $0.0-5.0$ & $0.116(\mathrm{~J})$ \\
\hline BK4 & 371BK05 & $0.0-5.0$ & $0.51(\mathrm{~J})$ \\
\hline
\end{tabular}

$\mathrm{J}=$ Estimated value

Table F.2-30

Sample Results for Isotopes Detected above MDCs at Sample Plot BK

\begin{tabular}{|c|c|c|c|c|c|c|c|c|}
\hline \multirow{2}{*}{$\begin{array}{l}\text { Sample } \\
\text { Location }\end{array}$} & \multirow{2}{*}{$\begin{array}{l}\text { Sample } \\
\text { Number }\end{array}$} & \multirow{2}{*}{$\begin{array}{l}\text { Depth } \\
\text { (cm bgs) }\end{array}$} & \multicolumn{6}{|c|}{ COPCs (pCi/g) } \\
\hline & & & Pu-238 & Pu-239/240 & Sr-90 & U-234 & U-235 & U-238 \\
\hline \multicolumn{3}{|c|}{ FALs } & 13 & 12.7 & 838 & 143 & 17.6 & 105 \\
\hline BK1 & 371BK01 & $0.0-5.0$ & -- & $0.52(\mathrm{~J})$ & 1.35 & $4.55(\mathrm{~J})$ & $0.2(\mathrm{~J})$ & 0.96 \\
\hline BK2 & 371BK02 & $0.0-5.0$ & 0.122 & $0.75(\mathrm{~J})$ & 1.58 & $8.2(\mathrm{~J})$ & $0.42(\mathrm{~J})$ & 0.97 \\
\hline \multirow{2}{*}{ BK3 } & 371BK03 & $0.0-5.0$ & -- & $0.306(\mathrm{~J})$ & 1.76 & $4.72(\mathrm{~J})$ & $0.26(\mathrm{~J})$ & 0.93 \\
\hline & 371BK04 & $0.0-5.0$ & 0.172 & $0.96(\mathrm{~J})$ & 1.43 & $9.8(\mathrm{~J})$ & $0.44(\mathrm{~J})$ & 0.9 \\
\hline BK4 & 371BK05 & $0.0-5.0$ & 0.111 & $4.05(\mathrm{~J})$ & 1.61 & $3.68(\mathrm{~J})$ & -- & 0.88 \\
\hline
\end{tabular}

$\mathrm{J}=$ Estimated value

$--=$ Not detected above MDCs. 
Table F.2-31

Sample Results for Gamma-Emitting Radionuclides Detected above MDCs at Sample Plot BL

\begin{tabular}{||c|c|c|c|c|c|c|c|c||}
\hline \multirow{2}{*}{$\begin{array}{c}\text { Sample } \\
\text { Location }\end{array}$} & \multirow{2}{*}{$\begin{array}{c}\text { Sample } \\
\text { Number }\end{array}$} & \multirow{2}{*}{$\begin{array}{c}\text { Depth } \\
\mathbf{( c m} \text { bgs) }\end{array}$} & \multicolumn{7}{|c|}{ COPCs (pCi/g) } \\
\cline { 4 - 10 } & & & Ac-228 & Cs-137 & Eu-152 & Pb-212 & Pb-214 & TI-208 \\
\hline \multicolumn{3}{|c|}{ FALs } & $\mathbf{5}$ & $\mathbf{1 2 . 2}$ & $\mathbf{5 . 6 7}$ & $\mathbf{5}$ & $\mathbf{5}$ & $\mathbf{5}$ \\
\hline \hline BL1 & $371 \mathrm{BL} 01$ & $0.0-5.0$ & 2.22 & 5.84 & 1.56 & 2.33 & $1.07(\mathrm{~J})$ & 0.75 \\
\hline BL2 & $371 \mathrm{BL} 02$ & $0.0-5.0$ & 2.18 & 7.04 & 1.76 & 2.13 & $1.12(\mathrm{~J})$ & 0.74 \\
\hline BL3 & $371 \mathrm{BL} 03$ & $0.0-5.0$ & 2.21 & 5.42 & 1.56 & 2.38 & $1.17(\mathrm{~J})$ & 0.74 \\
\hline BL4 & $371 \mathrm{BL} 04$ & $0.0-5.0$ & 2.12 & 5.93 & 1.85 & 2.47 & $1.17(\mathrm{~J})$ & 0.78 \\
\hline
\end{tabular}

$\mathrm{J}=$ Estimated value

Table F.2-32

Sample Results for Am-241 Detected above MDCs at Sample Plot BL

\begin{tabular}{||c|c|c|c|}
\hline \multirow{2}{*}{$\begin{array}{c}\text { Sample } \\
\text { Location }\end{array}$} & \multirow{2}{*}{$\begin{array}{c}\text { Sample } \\
\text { Number }\end{array}$} & $\begin{array}{c}\text { Depth } \\
\text { (cm bgs) }\end{array}$ & COPCs (pCi/g) \\
\cline { 4 - 5 } & & & 12.7 \\
\hline \hline \multicolumn{3}{|c|}{ FALs } & Am-241 \\
\hline BL1 & 371BL01 & $0.0-5.0$ & $0.105(\mathrm{~J})$ \\
\hline BL2 & 371BL02 & $0.0-5.0$ & $0.118(\mathrm{~J})$ \\
\hline BL4 & 371BL04 & $0.0-5.0$ & $0.4(\mathrm{~J})$ \\
\hline
\end{tabular}

$\mathrm{J}=$ Estimated value 
Table F.2-33

Sample Results for Isotopes Detected above MDCs at Sample Plot BL

\begin{tabular}{|c|c|c|c|c|c|c|c|c|}
\hline \multirow{2}{*}{$\begin{array}{c}\text { Sample } \\
\text { Location }\end{array}$} & \multirow{2}{*}{$\begin{array}{l}\text { Sample } \\
\text { Number }\end{array}$} & \multirow{2}{*}{$\begin{array}{c}\text { Depth } \\
\text { (cm bgs) }\end{array}$} & \multicolumn{6}{|c|}{ COPCs (pCi/g) } \\
\hline & & & Pu-238 & Pu-239/240 & Sr-90 & U-234 & U-235 & U-238 \\
\hline \multicolumn{3}{|c|}{ FALs } & 13 & 12.7 & 838 & 143 & 17.6 & 105 \\
\hline BL1 & 371BL01 & $0.0-5.0$ & 0.216 & $1.04(\mathrm{~J})$ & 2.86 & $1.65(\mathrm{~J})$ & $0.085(\mathrm{~J})$ & 0.9 \\
\hline BL2 & 371BL02 & $0.0-5.0$ & 0.217 & $1.26(\mathrm{~J})$ & 3 & $1.55(\mathrm{~J})$ & $0.131(\mathrm{~J})$ & 0.75 \\
\hline BL3 & 371BL03 & $0.0-5.0$ & -- & $0.3(\mathrm{~J})$ & 2.18 & $1.43(\mathrm{~J})$ & $0.095(\mathrm{~J})$ & 0.85 \\
\hline BL4 & 371BL04 & $0.0-5.0$ & 0.34 & $1.64(\mathrm{~J})$ & 2.62 & $2.06(\mathrm{~J})$ & $0.196(\mathrm{~J})$ & 0.87 \\
\hline
\end{tabular}

$\mathrm{J}=$ Estimated value

-- = Not detected above MDCs.

Table F.2-34

Sample Results for Gamma-Emitting Radionuclides Detected above MDCs at Sample Plot BM

\begin{tabular}{|c|c|c|c|c|c|c|c|c|c|}
\hline \multirow{2}{*}{$\begin{array}{l}\text { Sample } \\
\text { Location }\end{array}$} & \multirow{2}{*}{$\begin{array}{l}\text { Sample } \\
\text { Number }\end{array}$} & \multirow{2}{*}{$\begin{array}{l}\text { Depth } \\
\text { (cm bgs) }\end{array}$} & \multicolumn{7}{|c|}{ COPCs (pCi/g) } \\
\hline & & & Ac-228 & Cs-137 & Eu-152 & $\mathrm{Pb}-212$ & $\mathrm{~Pb}-214$ & TI-208 & Th-234 \\
\hline \multicolumn{3}{|c|}{ FALs } & 5 & 12.2 & 5.67 & 5 & 5 & 5 & 105 \\
\hline BM1 & 371BM01 & $0.0-5.0$ & 2.31 & 0.85 & -- & 2.26 & $1.18(\mathrm{~J})$ & 0.71 & 3.24 \\
\hline BM2 & 371BM02 & $0.0-5.0$ & 2.22 & 0.96 & 0.349 & 2.38 & $1.24(\mathrm{~J})$ & 0.74 & 2.48 \\
\hline BM3 & 371BM03 & $0.0-5.0$ & 2.33 & 0.84 & 0.272 & 2.21 & $1.23(\mathrm{~J})$ & 0.73 & 2.5 \\
\hline BM4 & 371BM04 & $0.0-5.0$ & 2.23 & 0.78 & 0.233 & 2.1 & $1.25(\mathrm{~J})$ & 0.7 & -- \\
\hline
\end{tabular}

$\mathrm{J}=$ Estimated value

$--=$ Not detected above MDCs. 
Table F.2-35

Sample Results for Am-241 Detected above MDCs at Sample Plot BM

\begin{tabular}{|c|c|c|c|}
\hline \multirow{2}{*}{$\begin{array}{l}\text { Sample } \\
\text { Location }\end{array}$} & \multirow{2}{*}{$\begin{array}{l}\text { Sample } \\
\text { Number }\end{array}$} & \multirow{2}{*}{$\begin{array}{c}\text { Depth (cm } \\
\text { bgs) }\end{array}$} & COPCs (pCi/g) \\
\hline & & & Am-241 \\
\hline \multicolumn{3}{|c|}{ FALs } & 12.7 \\
\hline BM1 & 371BM01 & $0.0-5.0$ & $0.142(\mathrm{~J})$ \\
\hline BM2 & 371BM02 & $0.0-5.0$ & $0.113(\mathrm{~J})$ \\
\hline BM3 & 371BM03 & $0.0-5.0$ & $0.199(\mathrm{~J})$ \\
\hline
\end{tabular}

$\mathrm{J}=$ Estimated value

Table F.2-36

Sample Results for Isotopes Detected above MDCs at Sample Plot BM

\begin{tabular}{|c|c|c|c|c|c|c|c|}
\hline \multirow{2}{*}{$\begin{array}{l}\text { Sample } \\
\text { Location }\end{array}$} & \multirow{2}{*}{$\begin{array}{l}\text { Sample } \\
\text { Number }\end{array}$} & \multirow{2}{*}{$\begin{array}{c}\text { Depth } \\
\text { (cm bgs) }\end{array}$} & \multicolumn{5}{|c|}{ COPCs (pCi/g) } \\
\hline & & & Pu-238 & Pu-239/240 & U-234 & U-235 & U-238 \\
\hline \multicolumn{3}{|c|}{ FALs } & 13 & 12.7 & 143 & 17.6 & 105 \\
\hline BM1 & 371BM01 & $0.0-5.0$ & 0.197 & $1.15(\mathrm{~J})$ & $0.84(\mathrm{~J})$ & -- & 0.8 \\
\hline BM2 & 371BM02 & $0.0-5.0$ & 0.136 & $0.77(\mathrm{~J})$ & $1.07(\mathrm{~J})$ & -- & 0.99 \\
\hline BM3 & 371BM03 & $0.0-5.0$ & 0.241 & $1.2(\mathrm{~J})$ & $0.81(\mathrm{~J})$ & $0.075(\mathrm{~J})$ & 0.83 \\
\hline BM4 & 371BM04 & $0.0-5.0$ & 0.106 & $0.61(\mathrm{~J})$ & $1.01(\mathrm{~J})$ & -- & 0.88 \\
\hline
\end{tabular}

$\mathrm{J}=$ Estimated value

-- = Not detected above MDCs. 
Table F.2-37

\section{Sample Results for Gamma-Emitting Radionuclides Detected above MDCs at Sample Plot BN}

\begin{tabular}{|c|c|c|c|c|c|c|c|c|c|c|}
\hline \multirow{2}{*}{$\begin{array}{l}\text { Sample } \\
\text { Location }\end{array}$} & \multirow{2}{*}{$\begin{array}{l}\text { Sample } \\
\text { Number }\end{array}$} & \multirow{2}{*}{$\begin{array}{c}\text { Depth } \\
\text { (cm bgs) }\end{array}$} & \multicolumn{8}{|c|}{ cOPCs (pCi/g) } \\
\hline & & & Ac-228 & Co-60 & Cs-137 & Eu-152 & Eu-154 & $\mathrm{Pb}-212$ & $\mathrm{~Pb}-214$ & TI-208 \\
\hline \multicolumn{3}{|c|}{ FALs } & 5 & 2.68 & 12.2 & 5.67 & 5.4 & 5 & 5 & 5 \\
\hline BN1 & 371BN01 & $0.0-5.0$ & 2.31 & 1.07 & 60.4 & 14.4 & 2.18 & 2.39 & $1.17(\mathrm{~J})$ & 0.71 \\
\hline \multirow{2}{*}{ BN2 } & 371BN02 & $0.0-5.0$ & 2.25 & 1.12 & 62.1 & $15.8(\mathrm{~J})$ & $2.41(\mathrm{~J})$ & $2.25(\mathrm{~J})$ & $1.29(\mathrm{~J})$ & 0.73 \\
\hline & 371BN03 & $0.0-5.0$ & 2.13 & 1.16 & 62 & 15.9 & 2.75 & 2.49 & $1.1(\mathrm{~J})$ & 0.74 \\
\hline BN3 & 371BN04 & $0.0-5.0$ & 2.28 & 0.97 & 59.5 & $13.9(\mathrm{~J})$ & $1.66(\mathrm{~J})$ & $2.39(\mathrm{~J})$ & $1.23(\mathrm{~J})$ & 0.77 \\
\hline BN4 & 371BN05 & $0.0-5.0$ & 2.35 & 1.22 & 61.3 & 16.5 & 2.43 & 2.19 & $1.16(\mathrm{~J})$ & 0.72 \\
\hline
\end{tabular}

$\mathrm{J}=$ Estimated value

Bold indicates the values exceeding the FALs.

Table F.2-38

Sample Results for Isotopes Detected above MDCs at Sample Plot BN

\begin{tabular}{|c|c|c|c|c|c|c|c|c|}
\hline \multirow{2}{*}{$\begin{array}{l}\text { Sample } \\
\text { Location }\end{array}$} & \multirow{2}{*}{$\begin{array}{l}\text { Sample } \\
\text { Number }\end{array}$} & \multirow{2}{*}{$\begin{array}{c}\text { Depth } \\
\text { (cm bgs) }\end{array}$} & \multicolumn{6}{|c|}{ COPCs (pCi/g) } \\
\hline & & & Pu-238 & Pu-239/240 & Sr-90 & U-234 & U-235 & U-238 \\
\hline \multicolumn{3}{|c|}{ FALs } & 13 & 12.7 & 838 & 143 & 17.6 & 105 \\
\hline BN1 & 371BN01 & $0.0-5.0$ & -- & 0.56 & $4.7(\mathrm{~J})$ & 9.9 & 0.4 & 1.01 \\
\hline \multirow{2}{*}{$\mathrm{BN} 2$} & 371BN02 & $0.0-5.0$ & 0.059 & 0.53 & $5.6(\mathrm{~J})$ & 11.5 & 0.44 & 1.03 \\
\hline & 371BN03 & $0.0-5.0$ & -- & 0.36 & $5.8(\mathrm{~J})$ & 9.8 & 0.36 & 0.97 \\
\hline BN3 & 371BN04 & $0.0-5.0$ & -- & 0.48 & $6.8(\mathrm{~J})$ & 15.4 & 0.59 & 1.13 \\
\hline BN4 & 371BN05 & $0.0-5.0$ & -- & 0.8 & $4.4(\mathrm{~J})$ & 22.8 & 0.63 & 1.09 \\
\hline
\end{tabular}

$\mathrm{J}=$ Estimated value

$--=$ Not detected above MDCs. 
Table F.2-39

Sample Results for Gamma-Emitting Radionuclides Detected above MDCs at Sample Plot BP

\begin{tabular}{|c|c|c|c|c|c|c|c|c|c|c|}
\hline \multirow{2}{*}{$\begin{array}{l}\text { Sample } \\
\text { Location }\end{array}$} & \multirow{2}{*}{$\begin{array}{l}\text { Sample } \\
\text { Number }\end{array}$} & \multirow{2}{*}{$\begin{array}{c}\text { Depth } \\
\text { (cm bgs) }\end{array}$} & \multicolumn{8}{|c|}{ COPCs (pCi/g) } \\
\hline & & & Ac-228 & Co-60 & Cs-137 & Eu-152 & Eu-154 & Pb-212 & $\mathrm{Pb}-214$ & TI-208 \\
\hline \multicolumn{3}{|c|}{ FALs } & 5 & 2.68 & 12 & 5.67 & 5.4 & 5 & 5 & 5 \\
\hline BP1 & 371BP01 & $0.0-5.0$ & 2.31 & 0.571 & 17.2 & $5.45(\mathrm{~J})$ & $1.19(\mathrm{~J})$ & $2.55(\mathrm{~J})$ & $1.33(\mathrm{~J})$ & 0.75 \\
\hline BP2 & 371BP02 & $0.0-5.0$ & 2.39 & 0.66 & 20.4 & $6.64(\mathrm{~J})$ & $1.12(\mathrm{~J})$ & $2.41(\mathrm{~J})$ & $1.38(\mathrm{~J})$ & 0.79 \\
\hline BP3 & 371BP03 & $0.0-5.0$ & 2.27 & 0.82 & 24.8 & $8.24(\mathrm{~J})$ & $1.61(\mathrm{~J})$ & $2.48(\mathrm{~J})$ & $1.43(\mathrm{~J})$ & 0.85 \\
\hline BP4 & 371BP04 & $0.0-5.0$ & 2.21 & 0.479 & 16.4 & $5.4(\mathrm{~J})$ & $1.12(\mathrm{~J})$ & $2.58(\mathrm{~J})$ & $1.35(\mathrm{~J})$ & 0.85 \\
\hline
\end{tabular}

$\mathrm{J}=$ Estimated value

$--=$ Not detected above MDCs.

Bold indicates the values exceeding the FALs.

Table F.2-40

Sample Results for Am-241 Detected above MDCs at Sample Plot BP

\begin{tabular}{|c|c|c|c||}
\hline \multirow{2}{*}{$\begin{array}{c}\text { Sample } \\
\text { Location }\end{array}$} & \multirow{2}{*}{$\begin{array}{c}\text { Sample } \\
\text { Number }\end{array}$} & \multirow{2}{*}{$\begin{array}{c}\text { Depth } \\
\text { (cm bgs) }\end{array}$} & COPCs (pCi/g) \\
\cline { 4 - 4 } & & & $\mathbf{A m - 2 4 1}$ \\
\hline \multicolumn{3}{|c|}{ FALs } & $\mathbf{1 2 . 7}$ \\
\hline \hline BP1 & $371 \mathrm{BP01}$ & $0.0-5.0$ & $0.137(\mathrm{~J})$ \\
\hline BP2 & $371 \mathrm{BP02}$ & $0.0-5.0$ & $0.165(\mathrm{~J})$ \\
\hline BP3 & $371 \mathrm{BP03}$ & $0.0-5.0$ & $0.056(\mathrm{~J})$ \\
\hline BP4 & $371 \mathrm{BP} 04$ & $0.0-5.0$ & $0.147(\mathrm{~J})$ \\
\hline
\end{tabular}

$\mathrm{J}=$ Estimated value 
Table F.2-41

Sample Results for Isotopes Detected above MDCs at Sample Plot BP

\begin{tabular}{|c|c|c|c|c|c|c|c|}
\hline \multirow{2}{*}{$\begin{array}{l}\text { Sample } \\
\text { Location }\end{array}$} & \multirow{2}{*}{$\begin{array}{l}\text { Sample } \\
\text { Number }\end{array}$} & \multirow{2}{*}{$\begin{array}{c}\text { Depth } \\
\text { (cm bgs) }\end{array}$} & \multicolumn{5}{|c|}{ COPCs (pCi/g) } \\
\hline & & & Pu-238 & $\mathrm{Pu}-239 / 240$ & U-234 & U-235 & U-238 \\
\hline \multicolumn{3}{|c|}{ FALs } & 13 & 12.7 & 143 & 17.6 & 105 \\
\hline BP1 & 371BP01 & $0.0-5.0$ & 0.274 & $1.25(\mathrm{~J})$ & 6.8 & 0.257 & 0.93 \\
\hline BP2 & 371BP02 & $0.0-5.0$ & 0.325 & $1.64(\mathrm{~J})$ & 17.2 & 0.63 & 1.13 \\
\hline BP3 & 371ВР03 & $0.0-5.0$ & 0.121 & $0.97(\mathrm{~J})$ & 13 & 0.44 & 0.89 \\
\hline BP4 & 371BP04 & $0.0-5.0$ & 0.209 & $0.74(\mathrm{~J})$ & 1.2 & 0.108 & 0.92 \\
\hline
\end{tabular}

$\mathrm{J}=$ Estimated value 


\section{Appendix G}

\section{Borehole and Sample Location Coordinates}




\section{G.1.0 Sample Location Coordinates}

The southwest corner of each sample plot and the locations of individual (judgmental) sample locations for the CAU 371 CASs were surveyed using a Trimble GeoXT GPS Unit with submeter-level accuracy. Survey coordinates for these locations are listed in Tables G.1-1 and G.1-2.

Table G.1-1

Sample Plot/Location Coordinates for Pin Stripe ${ }^{a}$

\begin{tabular}{|c|c|c|}
\hline Easting $^{\text {b }}$ & Northing $^{\text {b }}$ & Sample Plot/Location $^{-1}$ \\
\hline \hline 594362.7 & 4082666.2 & $\mathrm{AA}$ \\
\hline 594382.0 & 4082738.6 & $\mathrm{AB}$ \\
\hline 594348.3 & 4082619.0 & $\mathrm{AC}$ \\
\hline 594382.3 & 4082815.8 & $\mathrm{AE}$ \\
\hline 594346.1 & 4082606.4 & $\mathrm{AF}$ \\
\hline 594369.3 & 4082669.6 & A01 (Fissure Sample AX1) \\
\hline
\end{tabular}

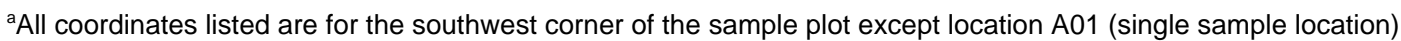

bUniversal Transverse Mercator (UTM) Zone 11, North American Datum (NAD) 1927 (U.S. Western) in meters.

Table G.1-2

Sample Plot/Location Coordinates for Johnnie Boy ${ }^{\mathrm{a}}$

(Page 1 of 2)

\begin{tabular}{||c|c|c||}
\hline Easting $^{\mathbf{b}}$ & Northing $^{\mathbf{b}}$ & Sample Plot/Location \\
\hline \hline 559286.5 & 4108534.2 & BA \\
\hline 559252.5 & 4108586.0 & BB \\
\hline 559264.8 & 4108645.8 & BC \\
\hline 559266.9 & 4108709.3 & BE \\
\hline 559299.5 & 4108487.8 & BF \\
\hline 559337.6 & 4108469.3 & BG \\
\hline 559354.3 & 4108443.4 & BH \\
\hline 559425.2 & 4108386.1 & BJ \\
\hline 559244.2 & 4108525.5 & BK \\
\hline 559210.6 & 4108529.4 & BL \\
\hline 559165.8 & 4108541.3 & BM \\
\hline 559101.0 & 4108554.0 & \\
\hline
\end{tabular}


Table G.1-2

Sample Plot/Location Coordinates for Johnnie Boy ${ }^{\mathrm{a}}$

(Page 2 of 2)

\begin{tabular}{|c|c|c|}
\hline Easting $^{b}$ & Northing $^{b}$ & Sample Plot/Location \\
\hline 559265.9 & 4108469.7 & $\mathrm{BN}$ \\
\hline 559285.2 & 4108974.7 & BP \\
\hline \multicolumn{3}{|c|}{ Sedimentation Areas and Ejecta } \\
\hline 559333.6 & 4108434.4 & B01 (Sed. Area) \\
\hline 559333.7 & 4108333.6 & B02 (Sed. Area) \\
\hline 559245.6 & 4108470.3 & B03 (Ejecta) \\
\hline 559273.0 & 4108465.0 & B04 (Ejecta \\
\hline
\end{tabular}

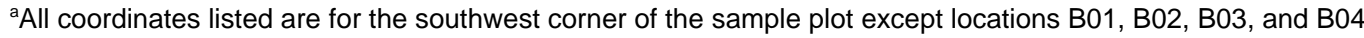
(single sample locations)

bUTM Zone 11, NAD 1927 (U.S. Western) in meters.

Nine aliquot sample locations were established at each plot for each composite sample (4 composite samples, 36 aloquoit sample locations). The VSP software (PNNL, 2007) was used to derive coordinates for a systematic triangular grid pattern based on a randomly generated origin or starting point. The sample aliquot locations for each composite sample are in a tabular format in terms of east and north distances from the southwest corner stake at each plot (Tables G.1-3 and G.1-4).

In some cases, aliquot locations were moved due to surface/subsurface obstructions or conditions (e.g., rocks, vegetation, and animal burrows). These offsets (distance and direction) of each aliquot location were recorded in the project files. It is important to note that if an offset was less than the nominal 4-in. width of core sampler the original coordinate was not modified. 
Table G.1-3

Sample Plot Location Distance (Pin Stripe) in Meters

(Page 1 of 2)

\begin{tabular}{|c|c|c|c|c|c|c|c|c|}
\hline \multicolumn{3}{|c|}{ Sample Plot AA } & \multicolumn{3}{|c|}{ Sample Plot AB } & \multicolumn{3}{|c|}{ Sample Plot AC } \\
\hline 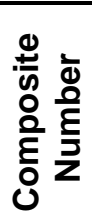 & 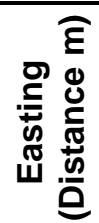 & 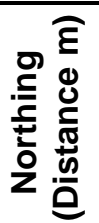 & 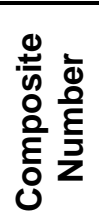 & 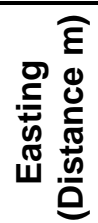 & 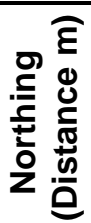 & 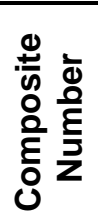 & 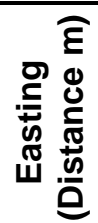 & 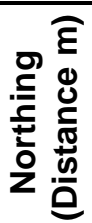 \\
\hline \multirow{9}{*}{ AA1 } & $\overline{1.0}$ & 2.4 & \multirow{9}{*}{ AB1 } & 0.2 & $\overline{1.4}$ & \multirow{9}{*}{$\mathrm{AC1}$} & 1.9 & 2.9 \\
\hline & 4.6 & 2.4 & & 3.8 & 1.4 & & 5.5 & 2.9 \\
\hline & 8.2 & 2.4 & & 7.4 & 1.4 & & 9.1 & 2.9 \\
\hline & 2.8 & 5.5 & & 2.0 & 4.5 & & 0.1 & 6.0 \\
\hline & 6.4 & 5.5 & & 5.6 & 4.5 & & 3.7 & 6.0 \\
\hline & 10.0 & 5.5 & & 9.2 & 4.5 & & 7.3 & 6.0 \\
\hline & 1.0 & 8.7 & & 0.2 & 7.6 & & 1.9 & 9.1 \\
\hline & 4.6 & 8.7 & & 3.8 & 7.6 & & 5.5 & 9.1 \\
\hline & 8.2 & 8.7 & & 7.4 & 7.6 & & 9.1 & 9.1 \\
\hline \multirow{9}{*}{ AA2 } & 2.1 & 0.8 & \multirow{9}{*}{ AB2 } & 1.0 & 2.2 & \multirow{9}{*}{$\mathrm{AC} 2$} & 2.5 & 0.9 \\
\hline & 5.6 & 0.8 & & 4.6 & 2.2 & & 6.1 & 0.9 \\
\hline & 9.2 & 0.8 & & 8.2 & 2.2 & & 9.6 & 0.9 \\
\hline & 0.3 & 3.9 & & 2.8 & 5.3 & & 0.7 & 4.0 \\
\hline & 3.8 & 3.9 & & 6.4 & 5.3 & & 4.3 & 4.0 \\
\hline & 7.4 & 3.9 & & 10.0 & 5.3 & & 7.8 & 4.0 \\
\hline & 2.1 & 7.0 & & 1.0 & 8.4 & & 2.5 & 7.1 \\
\hline & 5.6 & 7.0 & & 4.6 & 8.4 & & 6.1 & 7.1 \\
\hline & 9.2 & 7.0 & & 8.2 & 8.4 & & 9.6 & 7.1 \\
\hline \multirow{9}{*}{ AA3 } & 0.9 & 1.8 & \multirow{9}{*}{ AB3 } & 0.2 & 2.9 & \multirow{9}{*}{ AC3 } & 0.4 & 1.6 \\
\hline & 4.5 & 1.8 & & 3.8 & 2.9 & & 4.0 & 1.6 \\
\hline & 8.1 & 1.8 & & 7.3 & 2.9 & & 7.6 & 1.6 \\
\hline & 2.7 & 4.9 & & 2.0 & 6.0 & & 2.2 & 4.7 \\
\hline & 6.3 & 4.9 & & 5.6 & 6.0 & & 5.8 & 4.7 \\
\hline & 9.9 & 4.9 & & 9.1 & 6.0 & & 9.4 & 4.7 \\
\hline & 0.9 & 8.0 & & 0.2 & 9.1 & & 0.4 & 7.8 \\
\hline & 4.5 & 8.0 & & 3.8 & 9.1 & & 4.0 & 7.8 \\
\hline & 8.1 & 8.0 & & 7.3 & 9.1 & & 7.6 & 7.8 \\
\hline \multirow{9}{*}{ AA4 } & 2.7 & 2.3 & \multirow{9}{*}{ AB4 } & 2.2 & 3.1 & \multirow{9}{*}{ AC4 } & 0.5 & 3.0 \\
\hline & 6.3 & 2.3 & & 5.8 & 3.1 & & 4.0 & 3.0 \\
\hline & 9.8 & 2.3 & & 9.4 & 3.1 & & 7.6 & 3.0 \\
\hline & 0.9 & 5.4 & & 0.4 & 6.2 & & 2.3 & 6.1 \\
\hline & 4.5 & 5.4 & & 4.0 & 6.2 & & 5.8 & 6.1 \\
\hline & 8.0 & 5.4 & & 7.6 & 6.2 & & 9.4 & 6.1 \\
\hline & 2.7 & 8.5 & & 2.2 & 9.3 & & 0.5 & 9.2 \\
\hline & 6.3 & 8.5 & & 5.8 & 9.3 & & 4.0 & 9.2 \\
\hline & 9.8 & 8.5 & & 9.4 & 9.3 & & 7.6 & 9.2 \\
\hline
\end{tabular}


Table G.1-3

Sample Plot Location Distance (Pin Stripe) in Meters (Page 2 of 2)

\begin{tabular}{|c|c|c|c|c|c|}
\hline \multicolumn{3}{|c|}{ Sample Plot AE } & \multicolumn{3}{|c|}{ Sample Plot AF } \\
\hline 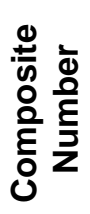 & 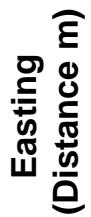 & 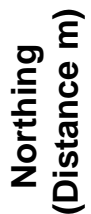 & 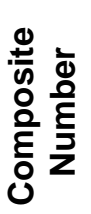 & 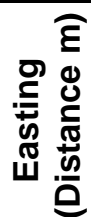 & 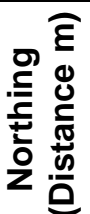 \\
\hline \multirow{9}{*}{ AE1 } & 0.9 & 0.9 & \multirow{9}{*}{ AF1 } & 1.0 & 0.7 \\
\hline & 4.5 & 0.9 & & 4.6 & 0.7 \\
\hline & 8.1 & 0.9 & & 8.2 & 0.7 \\
\hline & 2.7 & 4.0 & & 2.8 & 3.8 \\
\hline & 6.3 & 4.0 & & 6.4 & 3.8 \\
\hline & 9.9 & 4.0 & & 10 & 3.8 \\
\hline & 0.9 & 7.1 & & 1.0 & 6.9 \\
\hline & 4.5 & 7.1 & & 4.6 & 6.9 \\
\hline & 8.1 & 7.1 & & 8.2 & 6.9 \\
\hline \multirow{9}{*}{ AE2 } & 0.8 & 2.9 & \multirow{9}{*}{ AF2 } & 0.0 & 2.7 \\
\hline & 4.4 & 2.9 & & 3.6 & 2.7 \\
\hline & 8.0 & 2.9 & & 7.2 & 2.7 \\
\hline & 2.6 & 6.0 & & 1.8 & 5.8 \\
\hline & 6.2 & 6.0 & & 5.4 & 5.8 \\
\hline & 9.8 & 6.0 & & 9.0 & 5.8 \\
\hline & 0.8 & 9.1 & & 0.0 & 8.9 \\
\hline & 4.4 & 9.1 & & 3.6 & 8.9 \\
\hline & 8.0 & 9.1 & & 7.2 & 8.9 \\
\hline \multirow{9}{*}{ AE3 } & 2.5 & 1.9 & \multirow{9}{*}{ AF3 } & 2.0 & 1.9 \\
\hline & 6.1 & 1.9 & & 5.6 & 1.9 \\
\hline & 9.7 & 1.9 & & 9.2 & 1.9 \\
\hline & 0.7 & 5.0 & & 0.2 & 5.0 \\
\hline & 4.3 & 5.0 & & 3.8 & 5.0 \\
\hline & 7.9 & 5.0 & & 7.4 & 5.0 \\
\hline & 2.5 & 8.1 & & 2.0 & 8.1 \\
\hline & 6.1 & 8.1 & & 5.6 & 8.1 \\
\hline & 9.7 & 8.1 & & 9.2 & 8.1 \\
\hline \multirow{9}{*}{ AE4 } & 0.4 & 2.3 & \multirow{9}{*}{ AF4 } & 2.8 & 2.1 \\
\hline & 4.0 & 2.3 & & 6.4 & 2.1 \\
\hline & 7.5 & 2.3 & & 10 & 2.1 \\
\hline & 2.2 & 5.4 & & 1.0 & 5.2 \\
\hline & 5.8 & 5.4 & & 4.6 & 5.2 \\
\hline & 9.3 & 5.4 & & 8.2 & 5.2 \\
\hline & 0.4 & 8.5 & & 2.8 & 8.3 \\
\hline & 4.0 & 8.5 & & 6.4 & 8.3 \\
\hline & 7.5 & 8.5 & & 10 & 8.3 \\
\hline
\end{tabular}

Note: Coordinate distance is measured from the southwest corner of the sample plot to the east (Easting) and to the north (Northing)

(e.g., at Sample Plot AA1, measure $1.0 \mathrm{~m}$ to the east of the southwest corner and $2.4 \mathrm{~m}$ to the north for the first location). 
Table G.1-4

Sample Plot Location Distance (Johnnie Boy) in Meters

(Page 1 of 4)

\begin{tabular}{|c|c|c|c|c|c|c|c|c|c|c|c|}
\hline \multicolumn{3}{|c|}{ Sample Plot BA } & \multicolumn{3}{|c|}{ Sample Plot BB } & \multicolumn{3}{|c|}{ Sample Plot BC } & \multicolumn{3}{|c|}{ Sample Plot BD } \\
\hline 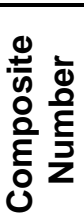 & 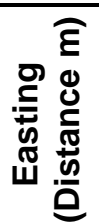 & 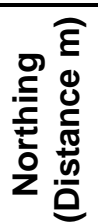 & 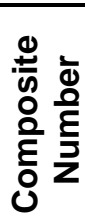 & 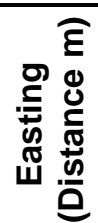 & 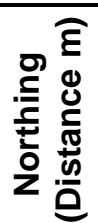 & 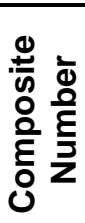 & 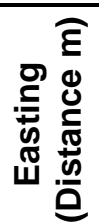 & 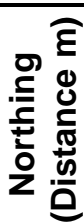 & 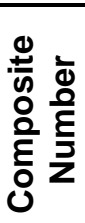 & 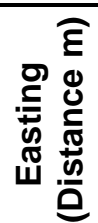 & 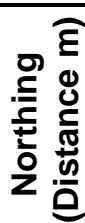 \\
\hline \multirow{9}{*}{ BA1 } & 0.9 & 0.9 & \multirow{9}{*}{ BB1 } & 2.5 & 1.1 & \multirow{9}{*}{ BC1 } & 0.5 & 0.8 & \multirow{9}{*}{ BD1 } & 2.6 & 1.3 \\
\hline & 4.5 & 0.9 & & 6.1 & 1.1 & & 4.1 & 0.8 & & 6.2 & 1.3 \\
\hline & 8.1 & 0.9 & & 9.7 & 1.1 & & 7.6 & 0.8 & & 9.7 & 1.3 \\
\hline & 2.7 & 4.0 & & 0.7 & 4.2 & & 2.3 & 3.9 & & 0.8 & 4.4 \\
\hline & 6.3 & 4.0 & & 4.3 & 4.2 & & 5.8 & 3.9 & & 4.4 & 4.4 \\
\hline & 9.9 & 4.0 & & 7.9 & 4.2 & & 9.4 & 3.9 & & 7.9 & 4.4 \\
\hline & 0.9 & 7.1 & & 2.5 & 7.3 & & 0.5 & 7.0 & & 2.6 & 7.5 \\
\hline & 4.5 & 7.1 & & 6.1 & 7.3 & & 4.1 & 7.0 & & 6.2 & 7.5 \\
\hline & 8.1 & 7.1 & & 9.7 & 7.3 & & 7.6 & 7.0 & & 9.7 & 7.5 \\
\hline \multirow{9}{*}{ BA2 } & 0.8 & 2.9 & \multirow{9}{*}{ BB2 } & 0.8 & 0.9 & \multirow{9}{*}{$\mathrm{BC} 2$} & 0.5 & 1.6 & \multirow{9}{*}{ BD2 } & 2.7 & 1.9 \\
\hline & 4.4 & 2.9 & & 4.4 & 0.9 & & 4.1 & 1.6 & & 6.3 & 1.9 \\
\hline & 8.0 & 2.9 & & 8.0 & 0.9 & & 7.7 & 1.6 & & 9.9 & 1.9 \\
\hline & 2.6 & 6.0 & & 2.6 & 4.0 & & 2.3 & 4.7 & & 1.0 & 5.0 \\
\hline & 6.2 & 6.0 & & 6.2 & 4.0 & & 5.9 & 4.7 & & 4.5 & 5.0 \\
\hline & 9.8 & 6.0 & & 9.8 & 4.0 & & 9.5 & 4.7 & & 8.1 & 5.0 \\
\hline & 0.8 & 9.1 & & $\begin{array}{l}0.8 \\
\end{array}$ & 7.1 & & 0.5 & $\begin{array}{l}7.8 \\
\end{array}$ & & 2.7 & 8.1 \\
\hline & 4.4 & 9.1 & & 4.4 & 7.1 & & 4.1 & $\begin{array}{l}7.8 \\
\end{array}$ & & 6.3 & 8.1 \\
\hline & 8.0 & 9.1 & & 8.0 & 7.1 & & 7.7 & 7.8 & & 9.9 & 8.1 \\
\hline \multirow{9}{*}{ BA3 } & 2.5 & 1.9 & \multirow{9}{*}{ BB3 } & 0.5 & 1.7 & \multirow{9}{*}{$\mathrm{BC} 3$} & 2.2 & 1.6 & \multirow{9}{*}{ BD3 } & 0.7 & 2.3 \\
\hline & 6.1 & 1.9 & & 4.0 & 1.7 & & 5.8 & 1.6 & & 4.3 & 2.3 \\
\hline & 9.7 & 1.9 & & 7.6 & 1.7 & & 9.4 & 1.6 & & 7.9 & 2.3 \\
\hline & 0.7 & 5.0 & & 2.3 & 4.8 & & 0.4 & 4.7 & & 2.5 & 5.4 \\
\hline & 4.3 & 5.0 & & 5.8 & 4.8 & & 4.0 & 4.7 & & 6.1 & 5.4 \\
\hline & 7.9 & 5.0 & & 9.4 & 4.8 & & 7.6 & 4.7 & & 9.7 & 5.4 \\
\hline & 2.5 & 8.1 & & 0.5 & 7.9 & & 2.2 & 7.8 & & 0.7 & 8.5 \\
\hline & 6.1 & 8.1 & & 4.0 & 7.9 & & 5.8 & 7.8 & & 4.3 & 8.5 \\
\hline & 9.7 & 8.1 & & 7.6 & 7.9 & & 9.4 & 7.8 & & 7.9 & 8.5 \\
\hline \multirow{9}{*}{ BA4 } & 0.4 & 2.3 & \multirow{9}{*}{ BB4 } & 2.8 & 2.7 & \multirow{9}{*}{ BC4 } & 0.9 & 2.8 & \multirow{9}{*}{ BD4 } & 2.4 & 2.7 \\
\hline & 4.0 & 2.3 & & 6.3 & 2.7 & & 4.5 & 2.8 & & 6.0 & 2.7 \\
\hline & 7.5 & 2.3 & & 9.9 & 2.7 & & 8.1 & 2.8 & & 9.6 & 2.7 \\
\hline & 2.2 & 5.4 & & 1.0 & 5.8 & & 2.7 & 5.9 & & 0.6 & 5.8 \\
\hline & 5.8 & 5.4 & & 4.5 & 5.8 & & 6.3 & 5.9 & & 4.2 & 5.8 \\
\hline & 9.3 & 5.4 & & 8.1 & 5.8 & & 9.9 & 5.9 & & 7.8 & 5.8 \\
\hline & 0.4 & 8.5 & & 2.8 & 8.9 & & 0.9 & 9.0 & & 2.4 & 8.9 \\
\hline & 4.0 & 8.5 & & 6.3 & 8.9 & & 4.5 & 9.0 & & 6.0 & 8.9 \\
\hline & 7.5 & 8.5 & & 9.9 & 8.9 & & 8.1 & 9.0 & & 9.6 & 8.9 \\
\hline
\end{tabular}


Table G.1-4

Sample Plot Location Distance (Johnnie Boy) in Meters

(Page 2 of 4 )

\begin{tabular}{|c|c|c|c|c|c|c|c|c|c|c|c|}
\hline \multicolumn{3}{|c|}{ Sample Plot BE } & \multicolumn{3}{|c|}{ Sample Plot BF } & \multicolumn{3}{|c|}{ Sample Plot BG } & \multicolumn{3}{|c|}{ Sample Plot BH } \\
\hline 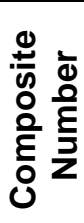 & 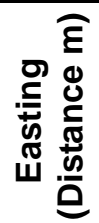 & 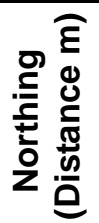 & 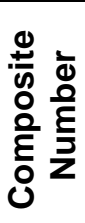 & 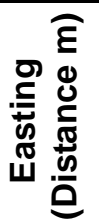 & 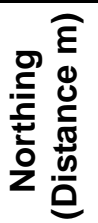 & 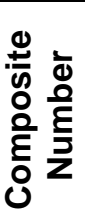 & 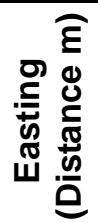 & 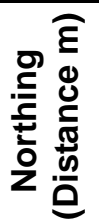 & 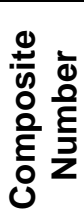 & 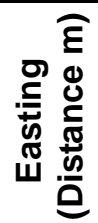 & 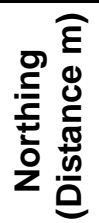 \\
\hline \multirow{9}{*}{ BE1 } & 1.0 & 0.7 & \multirow{9}{*}{ BF1 } & 0.7 & 2.2 & \multirow{9}{*}{ BG1 } & 0.9 & 2.4 & \multirow{9}{*}{$\mathrm{BH} 1$} & 0.7 & 1.0 \\
\hline & 4.6 & 0.7 & & 4.2 & 2.2 & & 4.5 & 2.4 & & 4.3 & 1.0 \\
\hline & 8.2 & 0.7 & & 7.8 & 2.2 & & 8.0 & 2.4 & & 7.9 & 1.0 \\
\hline & 2.8 & 3.8 & & 2.5 & 5.3 & & 2.7 & 5.5 & & 2.5 & 4.1 \\
\hline & $\begin{array}{l}6.4 \\
\end{array}$ & 3.8 & & 6.0 & 5.3 & & 6.3 & 5.5 & & 6.1 & 4.1 \\
\hline & 10 & 3.8 & & 9.6 & 5.3 & & 9.8 & 5.5 & & 9.7 & 4.1 \\
\hline & 1.0 & 6.9 & & 0.7 & 8.4 & & 0.9 & 8.6 & & 0.7 & 7.2 \\
\hline & 4.6 & 6.9 & & 4.2 & 8.4 & & 4.5 & 8.6 & & 4.3 & 7.2 \\
\hline & 8.2 & 6.9 & & 7.8 & 8.4 & & 8.0 & 8.6 & & $\begin{array}{l}7.9 \\
\end{array}$ & $\overline{7.2}$ \\
\hline \multirow{9}{*}{ BE2 } & 0.0 & 2.7 & \multirow{9}{*}{ BF2 } & 2.7 & 0.8 & \multirow{9}{*}{ BG2 } & 0.5 & 2.7 & \multirow{9}{*}{$\mathrm{BH} 2$} & 2.8 & 0.7 \\
\hline & 3.6 & 2.7 & & 6.3 & 0.8 & & 4.0 & 2.7 & & 6.3 & 0.7 \\
\hline & 7.2 & 2.7 & & 9.9 & 0.8 & & 7.6 & 2.7 & & 9.9 & 0.7 \\
\hline & 1.8 & 5.8 & & 1.0 & 3.9 & & 2.3 & 5.8 & & 1.0 & 3.8 \\
\hline & 5.4 & 5.8 & & 4.5 & 3.9 & & 5.8 & 5.8 & & 4.6 & 3.8 \\
\hline & 9.0 & 5.8 & & 8.1 & 3.9 & & 9.4 & 5.8 & & 8.1 & 3.8 \\
\hline & 0.0 & 8.9 & & 2.7 & 7.0 & & 0.5 & 8.9 & & 2.8 & 6.9 \\
\hline & 3.6 & 8.9 & & 6.3 & 7.0 & & 4.0 & 8.9 & & 6.3 & 6.9 \\
\hline & 7.2 & 8.9 & & 9.9 & 7.0 & & 7.6 & 8.9 & & 9.9 & 6.9 \\
\hline \multirow{9}{*}{ BE3 } & 2.0 & 1.9 & \multirow{9}{*}{ BF3 } & 0.4 & 3.0 & \multirow{9}{*}{ BG3 } & 0.4 & 1.2 & \multirow{9}{*}{$\mathrm{BH} 3$} & 2.8 & 2.6 \\
\hline & 5.6 & 1.9 & & 4.0 & 3.0 & & 4.0 & 1.2 & & 6.4 & 2.6 \\
\hline & 9.2 & 1.9 & & 7.6 & 3.0 & & 7.6 & 1.2 & & 10.0 & 2.6 \\
\hline & 0.2 & 5.0 & & 2.2 & 6.1 & & 2.2 & 4.3 & & 1.0 & 5.7 \\
\hline & 3.8 & 5.0 & & 5.8 & 6.1 & & 5.8 & 4.3 & & 4.6 & 5.7 \\
\hline & 7.4 & 5.0 & & 9.4 & 6.1 & & $\overline{9.4}$ & 4.3 & & 8.2 & 5.7 \\
\hline & 2.0 & 8.1 & & 0.4 & 9.2 & & 0.4 & 7.4 & & 2.8 & 8.8 \\
\hline & 5.6 & 8.1 & & 4.0 & 9.2 & & 4.0 & 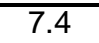 & & 6.4 & 8.8 \\
\hline & 9.2 & 8.1 & & 7.6 & 9.2 & & 7.6 & $\overline{7.4}$ & & 10.0 & 8.8 \\
\hline \multirow{9}{*}{ BE4 } & 2.8 & 2.1 & \multirow{9}{*}{ BF4 } & 2.0 & 2.9 & \multirow{9}{*}{ BG4 } & 2.3 & 1.9 & \multirow{9}{*}{$\mathrm{BH} 4$} & 2.1 & 2.3 \\
\hline & 6.4 & 2.1 & & 5.5 & 2.9 & & 5.8 & 1.9 & & 5.7 & 2.3 \\
\hline & 10 & 2.1 & & 9.1 & 2.9 & & 9.4 & 1.9 & & 9.3 & 2.3 \\
\hline & 1.0 & 5.2 & & 0.2 & 6.0 & & 0.5 & 5.0 & & 0.3 & 5.4 \\
\hline & 4.6 & 5.2 & & 3.8 & 6.0 & & 4.1 & 5.0 & & 3.9 & 5.4 \\
\hline & 8.2 & 5.2 & & 7.3 & 6.0 & & 7.6 & 5.0 & & 7.5 & 5.4 \\
\hline & 2.8 & 8.3 & & 2.0 & 9.1 & & 2.3 & 8.1 & & 2.1 & 8.5 \\
\hline & $\begin{array}{l}6.4 \\
\end{array}$ & 8.3 & & 5.5 & 9.1 & & 5.8 & 8.1 & & 5.7 & 8.5 \\
\hline & 10 & 8.3 & & 9.1 & 9.1 & & 9.4 & 8.1 & & 9.3 & 8.5 \\
\hline
\end{tabular}


Table G.1-4

Sample Plot Location Distance (Johnnie Boy) in Meters

(Page 3 of 4 )

\begin{tabular}{|c|c|c|c|c|c|c|c|c|c|c|c|}
\hline \multicolumn{3}{|c|}{ Sample Plot BJ } & \multicolumn{3}{|c|}{ Sample Plot BK } & \multicolumn{3}{|c|}{ Sample Plot BL } & \multicolumn{3}{|c|}{ Sample Plot BM } \\
\hline 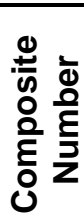 & 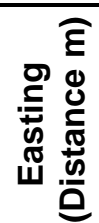 & 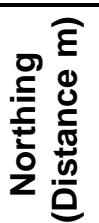 & 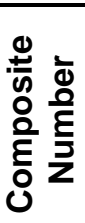 & 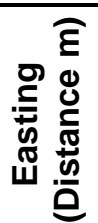 & 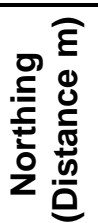 & 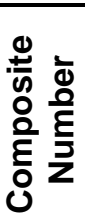 & 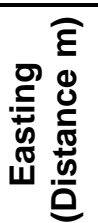 & 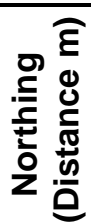 & 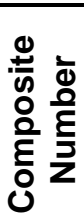 & 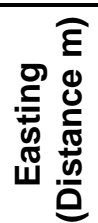 & 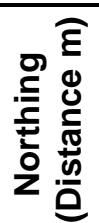 \\
\hline \multirow{9}{*}{ BJ1 } & $\overline{1.0}$ & 2.9 & \multirow{9}{*}{ BK1 } & $\overline{2.2}$ & 1.7 & \multirow{9}{*}{ BL1 } & 0.4 & 2.8 & \multirow{9}{*}{ BM1 } & 2.0 & 3.1 \\
\hline & 4.5 & 2.9 & & 5.8 & 1.7 & & 4.0 & 2.8 & & 5.6 & 3.1 \\
\hline & 8.1 & 2.9 & & 9.4 & 1.7 & & 7.5 & 2.8 & & 9.2 & 3.1 \\
\hline & 2.7 & 6.0 & & 0.4 & 4.8 & & 2.2 & 5.9 & & 0.3 & 6.2 \\
\hline & 6.3 & 6.0 & & 4.0 & 4.8 & & 5.8 & 5.9 & & 3.8 & 6.2 \\
\hline & 9.9 & 6.0 & & 7.6 & 4.8 & & 9.3 & 5.9 & & 7.4 & 6.2 \\
\hline & 1.0 & 9.1 & & 2.2 & 7.9 & & 0.4 & 9.0 & & 2.0 & 9.3 \\
\hline & 4.5 & 9.1 & & 5.8 & 7.9 & & 4.0 & 9.0 & & 5.6 & 9.3 \\
\hline & 8.1 & 9.1 & & 9.4 & 7.9 & & 7.5 & 9.0 & & 9.2 & 9.3 \\
\hline \multirow{9}{*}{ BJ2 } & 1.0 & 0.8 & \multirow{9}{*}{ BK2 } & 2.7 & 0.8 & \multirow{9}{*}{ BL2 } & 2.5 & 2.7 & \multirow{9}{*}{ BM2 } & 0.6 & 2.4 \\
\hline & 4.6 & 0.8 & & 6.3 & 0.8 & & 6.0 & 2.7 & & 4.2 & 2.4 \\
\hline & 8.1 & 0.8 & & 9.9 & 0.8 & & 9.6 & 2.7 & & 7.8 & 2.4 \\
\hline & 2.8 & 3.9 & & 0.9 & 3.9 & & 0.7 & 5.8 & & 2.4 & 5.5 \\
\hline & 6.4 & 3.9 & & 4.5 & 3.9 & & 4.2 & 5.8 & & 6.0 & 5.5 \\
\hline & 9.9 & 3.9 & & 8.1 & 3.9 & & $\begin{array}{l}7.8 \\
\end{array}$ & 5.8 & & 9.6 & 5.5 \\
\hline & 1.0 & 7.0 & & 2.7 & 7.0 & & 2.5 & 8.9 & & 0.6 & 8.6 \\
\hline & 4.6 & 7.0 & & 6.3 & 7.0 & & 6.0 & 8.9 & & 4.2 & 8.6 \\
\hline & 8.1 & 7.0 & & 9.9 & 7.0 & & 9.6 & 8.9 & & 7.8 & 8.6 \\
\hline \multirow{9}{*}{ BJ3 } & 0.5 & 1.8 & \multirow{9}{*}{ BK3 } & 2.7 & 3.1 & \multirow{9}{*}{ BL3 } & 0.0 & 1.8 & \multirow{9}{*}{ BM3 } & 2.4 & 2.0 \\
\hline & 4.1 & 1.8 & & 6.3 & 3.1 & & 3.6 & 1.8 & & 6.0 & 2.0 \\
\hline & 7.7 & 1.8 & & 9.9 & 3.1 & & 7.2 & 1.8 & & 9.6 & 2.0 \\
\hline & 2.3 & 4.9 & & 0.9 & 6.2 & & 1.8 & 4.9 & & 0.6 & 5.1 \\
\hline & 5.9 & 4.9 & & 4.5 & 6.2 & & 5.4 & 4.9 & & 4.2 & 5.1 \\
\hline & 9.5 & 4.9 & & 8.1 & 6.2 & & 9.0 & 4.9 & & 7.8 & 5.1 \\
\hline & 0.5 & 8.0 & & 2.7 & 9.3 & & 0.0 & 8.0 & & 2.4 & 8.2 \\
\hline & 4.1 & 8.0 & & 6.3 & 9.3 & & 3.6 & 8.0 & & 6.0 & 8.2 \\
\hline & 7.7 & 8.0 & & 9.9 & 9.3 & & 7.2 & 8.0 & & 9.6 & 8.2 \\
\hline \multirow{9}{*}{ BJ4 } & 2.6 & 1.3 & \multirow{9}{*}{ BK4 } & 0.8 & 1.1 & \multirow{9}{*}{ BL4 } & 2.7 & 1.3 & \multirow{9}{*}{ BM4 } & 1.0 & 1.8 \\
\hline & 6.2 & 1.3 & & 4.4 & 1.1 & & 6.3 & 1.3 & & 4.6 & 1.8 \\
\hline & 9.8 & 1.3 & & 8.0 & 1.1 & & 9.9 & 1.3 & & 8.2 & 1.8 \\
\hline & 0.8 & 4.4 & & 2.6 & 4.2 & & 0.9 & 4.4 & & 2.8 & 4.9 \\
\hline & 4.4 & 4.4 & & 6.2 & 4.2 & & 4.5 & 4.4 & & 6.4 & 4.9 \\
\hline & 8.0 & 4.4 & & 9.8 & 4.2 & & 8.1 & 4.4 & & 10.0 & 4.9 \\
\hline & 2.6 & 7.5 & & 0.8 & 7.3 & & 2.7 & 7.5 & & 1.0 & 8.0 \\
\hline & 6.2 & 7.5 & & 4.4 & 7.3 & & 6.3 & 7.5 & & 4.6 & 8.0 \\
\hline & 9.8 & 7.5 & & 8.0 & 7.3 & & 9.9 & 7.5 & & 8.2 & 8.0 \\
\hline
\end{tabular}


Table G.1-4

Sample Plot Location Distance (Johnnie Boy) in Meters (Page 4 of 4 )

\begin{tabular}{|c|c|c|c|c|c|}
\hline \multicolumn{3}{|c|}{ Sample Plot BN } & \multicolumn{3}{|c|}{ Sample Plot BP } \\
\hline 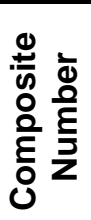 & 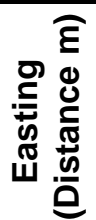 & 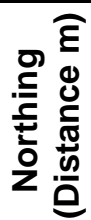 & 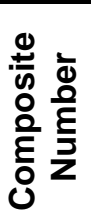 & 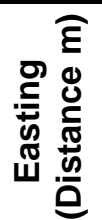 & 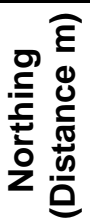 \\
\hline \multirow{9}{*}{ BN1 } & 1.0 & 2.4 & \multirow{9}{*}{ BP1 } & 0.2 & 1.4 \\
\hline & 4.6 & 2.4 & & 3.8 & 1.4 \\
\hline & 8.2 & 2.4 & & 7.4 & 1.4 \\
\hline & 2.8 & 5.5 & & 2.0 & 4.5 \\
\hline & 6.4 & 5.5 & & 5.6 & 4.5 \\
\hline & 10.0 & 5.5 & & 9.2 & 4.5 \\
\hline & 1.0 & 8.7 & & 0.2 & 7.6 \\
\hline & 4.6 & 8.7 & & 3.8 & 7.6 \\
\hline & 8.2 & 8.7 & & 7.4 & 7.6 \\
\hline \multirow{9}{*}{ BN2 } & 2.1 & 0.8 & \multirow{9}{*}{ BP2 } & 1.0 & 2.2 \\
\hline & 5.6 & 0.8 & & 4.6 & 2.2 \\
\hline & 9.2 & 0.8 & & 8.2 & 2.2 \\
\hline & 0.3 & 3.9 & & 2.8 & 5.3 \\
\hline & 3.8 & 3.9 & & 6.4 & 5.3 \\
\hline & 7.4 & 3.9 & & 10.0 & 5.3 \\
\hline & 2.1 & 7.0 & & 1.0 & 8.4 \\
\hline & 5.6 & 7.0 & & 4.6 & 8.4 \\
\hline & 9.2 & 7.0 & & 8.2 & 8.4 \\
\hline \multirow{9}{*}{ BN3 } & 0.9 & 1.8 & \multirow{9}{*}{ BP3 } & 0.2 & 2.9 \\
\hline & 4.5 & 1.8 & & 3.8 & 2.9 \\
\hline & 8.1 & 1.8 & & 7.3 & 2.9 \\
\hline & 2.7 & 4.9 & & 2.0 & 6.0 \\
\hline & 6.3 & 4.9 & & 5.6 & 6.0 \\
\hline & 9.9 & 4.9 & & 9.1 & 6.0 \\
\hline & 0.9 & 8.0 & & 0.2 & 9.1 \\
\hline & 4.5 & 8.0 & & 3.8 & 9.1 \\
\hline & 8.1 & 8.0 & & 7.3 & 9.1 \\
\hline \multirow{9}{*}{ BN4 } & 2.7 & 2.3 & \multirow{9}{*}{ BP4 } & 2.2 & 3.1 \\
\hline & 6.3 & 2.3 & & 5.8 & 3.1 \\
\hline & 9.8 & 2.3 & & 9.4 & 3.1 \\
\hline & 0.9 & 5.4 & & 0.4 & 6.2 \\
\hline & 4.5 & 5.4 & & 4.0 & 6.2 \\
\hline & 8.0 & 5.4 & & 7.6 & 6.2 \\
\hline & 2.7 & 8.5 & & 2.2 & 9.3 \\
\hline & 6.3 & 8.5 & & 5.8 & 9.3 \\
\hline & 9.8 & 8.5 & & 9.4 & 9.3 \\
\hline
\end{tabular}

Note: Coordinate distance is measured from the southwest corner of the sample plot to the east (Easting) and to the north (Northing) (e.g., at Sample Plot BA1, measure $0.9 \mathrm{~m}$ to the east of the southwest corner and $0.9 \mathrm{~m}$ to the north for the first location). 


\section{G.2.0 References}

PNNL, see Pacific Northwest National Laboratory.

Pacific Northwest National Laboratory. 2007. Visual Sample Plan, Version 5.0 User's Guide, PNNL-16939. Richland, WA. 


\section{Appendix $\mathrm{H}$}

\section{Nevada Division of Environmental Protection Comments}

(3 Pages) 
NEVADA ENVIRONMENTAL RESTORATION PROJECT

DOCUMENT REVIEW SHEET

\begin{tabular}{|c|c|c|c|c|c|c|}
\hline \multicolumn{2}{|c|}{ 1. Document Title/Number: } & \multicolumn{2}{|c|}{$\begin{array}{l}\text { Draft Corrective Action Decision Document/Closure Report for Corrective Action } \\
\text { Unit 371: Johnnie Boy Crater and Pin Stripe, Nevada Test Site, Nevada }\end{array}$} & \multirow{2}{*}{\begin{tabular}{|l|} 
2. Document Date: \\
4. Originator/Organization:
\end{tabular}} & \multicolumn{2}{|l|}{$6 / 1 / 2010$} \\
\hline \multicolumn{2}{|l|}{ 3. Revision Number: } & \multicolumn{2}{|l|}{0} & & \multicolumn{2}{|l|}{ Navarro-INTERA } \\
\hline \multicolumn{2}{|c|}{$\begin{array}{l}\text { 5. Responsible NNSA/NSO Federal } \\
\text { Sub-Project Director: }\end{array}$} & \multicolumn{2}{|l|}{ Kevin J. Cabble } & 6. Date Comments Due: & \multicolumn{2}{|l|}{$7 / 1 / 2010$} \\
\hline \multicolumn{2}{|l|}{ 7. Review Criteria: } & \multicolumn{2}{|l|}{ Full } & & & \\
\hline \multicolumn{2}{|c|}{ 8. Reviewer/Organization/Phone No: } & : Jeff MacDougall, NDEP, 486-2850, ext. 233 & & 9. Reviewer's Signature: & & \\
\hline $\begin{array}{l}\text { 10. Comment } \\
\text { Number/Location }\end{array}$ & \begin{tabular}{l|l}
11. Type $^{\star}$ & 1
\end{tabular} & 12. Comment & \multicolumn{3}{|c|}{ 13. Comment Response } & 14. Accept \\
\hline 1.) General & & $\begin{array}{l}\text { From the standpoint of content, explanation, and } \\
\text { recommended corrective actions for both Pin Stripe and } \\
\text { Johnnie Boy, we found the document to be adequate; all of } \\
\text { the essential CADD/CR document sections and relevant } \\
\text { discussions are included. We found the discussion on } \\
\text { TED, internal, and external dose assessment to be logical } \\
\text { and we do not have any specific comments. } \\
\text { However, as we reviewed the document, one issue stood } \\
\text { out which is significant in that it directly relates to the } \\
\text { selected corrective actions, or more specifically, the } \\
\text { defined areas that become subject to use restriction. The } \\
\text { document states that "..surface soils at Pin Stripe and } \\
\text { Johnnie Boy do not pose unacceptable risk..therefore, no } \\
\text { corrective action is necessary..." and consequently the use } \\
\text { restrictions established for the two sites are based on this } \\
\text { assertion. Upon reflection, we lack confidence in this } \\
\text { assertion, primarily due to the fact that all surface soil data } \\
\text { presented and reported in Appendix A is data which was } \\
\text { produced by samples collected from } 0-2 \text { inches below } \\
\text { ground surface. } \\
\text { Theoretically, wind and water erosion could result in the } \\
\text { displacement of the top } 2 \text { inches of soil over any given } \\
\text { span of time. If there exists higher radionuclide } \\
\text { concentrations (say at } 4 \text { inches below ground surface) this } \\
\text { then becomes the "new" surface soil which could possibly } \\
\text { pose a greater exposure risk than the one originally } \\
\text { considered. } \\
\text { This issue could be a general concern for future soils sites }\end{array}$ & \multicolumn{3}{|c|}{$\begin{array}{l}\text { From subsequent conversation with NDEP representatives, } \\
\text { it is understood that NDEP requests that future Soils } \\
\text { documents provide more discussion of the potential for } \\
\text { buried layers of contamination. In future CADD, CADD/CR, } \\
\text { or CR Soils documents, NNSA will provide the following: } \\
\text { 1. An assessment of the potential for areas not covered } \\
\text { by a corrective action boundary to contain buried } \\
\text { contamination that would exceed the final action level. This } \\
\text { would include areas where a contaminated surface may } \\
\text { have been removed and displaced or covered by less } \\
\text { contaminated soil. This discussion would include the } \\
\text { potential effect of contaminant concentration and resulting } \\
\text { dose to a receptor from the displacement of contaminated } \\
\text { soil (either mechanically or through erosion). } \\
\text { 2. A clarified discussion of the expected depth of } \\
\text { radionuclides that were deposited on the soil surface } \\
\text { through atmospheric deposition. This discussion would } \\
\text { need to justify the sampling depth for surface soil samples } \\
\text { by referencing (or adding as an Appendix) previous } \\
\text { contamination depth studies or a Soils Project specific } \\
\text { document that addresses this issue. } \\
\text { 3. Results of subsurface soil sample(s), as appropriate, to } \\
\text { confirm the conceptual site model element that } \\
\text { radionuclides deposited on the soil surface currently reside } \\
\text { primarily within the upper } 5 \text { cm of soil. } \\
\text { Although this comment was directed at future Soils } \\
\text { documents, Sections } 2.1 \text { and A.2.0 of the CAU } 371\end{array}$} & \\
\hline
\end{tabular}

Thursday, July 08, 2010

This issue could be a general concern for future soils sites 


\section{NEVADA ENVIRONMENTAL RESTORATION PROJECT DOCUMENT REVIEW SHEET}

\begin{tabular}{|c|c|c|c|c|c|c|}
\hline \multicolumn{2}{|c|}{ 1. Document Title/Number: } & \multicolumn{2}{|c|}{$\begin{array}{l}\text { Draft Corrective Action Decision Document/Closure Report for Corrective Action } \\
\text { Unit 371: Johnnie Boy Crater and Pin Stripe, Nevada Test Site, Nevada }\end{array}$} & \multirow{2}{*}{\begin{tabular}{|l|} 
2. Document Date: \\
4. Originator/Organization: \\
\end{tabular}} & \multicolumn{2}{|l|}{$6 / 1 / 2010$} \\
\hline \multicolumn{2}{|l|}{ 3. Revision Number: } & \multicolumn{2}{|l|}{0} & & \multicolumn{2}{|l|}{ Navarro-INTERA } \\
\hline \multicolumn{2}{|c|}{$\begin{array}{l}\text { 5. Responsible NNSA/NSO Federal } \\
\text { Sub-Project Director: }\end{array}$} & \multicolumn{2}{|l|}{ Kevin J. Cabble } & 6. Date Comments Due: & \multicolumn{2}{|l|}{$7 / 1 / 2010$} \\
\hline \multicolumn{2}{|c|}{ 7. Review Criteria: } & \multicolumn{2}{|l|}{ Full } & & & \\
\hline \multicolumn{2}{|c|}{ 8. Reviewer/Organization/Phone No: } & : Jeff MacDougall, NDEP, 486-2850, ext. 233 & & 9. Reviewer's Signature: & & \\
\hline \multirow[t]{2}{*}{$\begin{array}{l}\text { 10. Comment } \\
\text { Number/Location }\end{array}$} & 11. Type* & 12. Comment & \multicolumn{3}{|c|}{ 13. Comment Response } & 14. Accept \\
\hline & & $\begin{array}{l}\text { if we continue down this current path of closure in place } \\
\text { with use restrictions. Perhaps for future sites, DOE could } \\
\text { consider sampling surface soils at greater depths so as to } \\
\text { increase the confidence that these surface soils do not } \\
\text { pose unacceptable risks from an exposure standpoint. } \\
\text { NDEP would appreciate additional discussion and } \\
\text { explanation which addresses these points. }\end{array}$ & \multicolumn{3}{|c|}{$\begin{array}{l}\text { CADD/CR were revised to provide additional rationale for } \\
\text { limiting primary release surface soil samples to } 5 \mathrm{~cm} \text { in } \\
\text { depth. The bulleted paragraph (in both Sections } 2.1 \text { and } \\
\text { A.2.0) discussing primary releases was replaced with the } \\
\text { following text: } \\
\text { Primary releases are investigated via a combination of } \\
\text { external dose assessment using TLDs and internal dose } \\
\text { assessment through the collection and laboratory analysis } \\
\text { of surface soil samples. For the purposes of this } \\
\text { investigation, surface soils are defined as the top } 5 \\
\text { centimeters (cm) of undisturbed soil. Sampling surface } \\
\text { soils to a depth of } 5 \text { cm is appropriate for areas that have } \\
\text { not been disturbed since the release because: } \\
\text { 1. Numerous studies of soils contaminated by atmospheric } \\
\text { deposition following nuclear testing at the NTS have shown } \\
\text { that some } 90 \text { percent of the radioactivity in undisturbed soil } \\
\text { is contained within the top } 5 \text { cm of soil (DRI, } 1983 \text { and } \\
\text { 1985; Gilbert et al., } 1977 ; \text { Tamura, } 1977 \text { ). } \\
\text { 2. These studies show that as radiological contaminants } \\
\text { migrate downward in soils with water infiltration, the } \\
\text { contaminant concentration profile exhibits a lognormal } \\
\text { distribution with the maximum value remaining near the } \\
\text { surface. } \\
\text { 3. Sampling at a greater depth would collect non- } \\
\text { contaminated soil along with the contaminated soil. This } \\
\text { would serve to dilute the sample, reduce the analytical } \\
\text { result (in units of picocuries per gram of sample), and lower }\end{array}$} & \\
\hline
\end{tabular}




\section{NEVADA ENVIRONMENTAL RESTORATION PROJECT DOCUMENT REVIEW SHEET}

\begin{tabular}{|c|c|c|c|c|c|c|}
\hline \multicolumn{2}{|c|}{ 1. Document Title/Number: } & \multicolumn{2}{|c|}{$\begin{array}{l}\text { Draft Corrective Action Decision Document/Closure Report for Corrective Action } \\
\text { Unit 371: Johnnie Boy Crater and Pin Stripe, Nevada Test Site, Nevada }\end{array}$} & \multirow{2}{*}{\begin{tabular}{|l|} 
2. Document Date: \\
4. Originator/Organization: \\
\end{tabular}} & \multicolumn{2}{|l|}{$6 / 1 / 2010$} \\
\hline \multicolumn{2}{|l|}{ 3. Revision Number: } & \multicolumn{2}{|l|}{0} & & \multicolumn{2}{|l|}{ Navarro-INTERA } \\
\hline \multicolumn{2}{|c|}{$\begin{array}{l}\text { 5. Responsible NNSA/NSO Federal } \\
\text { Sub-Project Director: }\end{array}$} & \multicolumn{2}{|l|}{ Kevin J. Cabble } & 6. Date Comments Due: & \multicolumn{2}{|l|}{$7 / 1 / 2010$} \\
\hline \multicolumn{2}{|l|}{ 7. Review Criteria: } & \multicolumn{2}{|l|}{ Full } & & & \\
\hline \multicolumn{2}{|c|}{ 8. Reviewer/Organization/Phone No: } & \begin{tabular}{|l|l|}
$:$ & Jeff MacDougall, NDEP, 486-2850, ext. 233
\end{tabular} & & 9. Reviewer's Signature: & & \\
\hline \multirow{2}{*}{$\begin{array}{l}\text { 10. Comment } \\
\text { Number/Location }\end{array}$} & 11. Type* & 12. Comment & \multicolumn{3}{|c|}{ 13. Comment Response } & 14. Accept \\
\hline & & & \multicolumn{3}{|c|}{ the estimate of potential internal dose at the site. } & \\
\hline $\begin{array}{l}\text { 2.) 2nd } \\
\text { Paragraph, Page } \\
13\end{array}$ & & $\begin{array}{l}\text { On page } 13 \text {, second paragraph the table reference should } \\
\text { be Table A.3-5. }\end{array}$ & \multicolumn{3}{|c|}{$\begin{array}{l}\text { During the review of the Draft CAU } 371 \text { CADD/CR it was } \\
\text { noted that a table showing the internal dose estimations at } \\
\text { Pin Stripe sample plots was inadvertently omitted from } \\
\text { Section A.3.2.2. This table was re-inserted as Table A.3-5 } \\
\text { and the table numbering was updated. }\end{array}$} & \\
\hline
\end{tabular}




\section{Library Distribution List}

\section{$\underline{\text { Copies }}$}

U.S. Department of Energy

1 (Uncontrolled, electronic copy)

National Nuclear Security Administration

Nevada Site Office

Technical Library

P.O. Box 98518, M/S 505

Las Vegas, NV 89193-8518

U.S. Department of Energy

1 (Uncontrolled, electronic copy)

Office of Scientific and Technical Information

P.O. Box 62

Oak Ridge, TN 37831-0062

Southern Nevada Public Reading Facility

2 (Uncontrolled, electronic copies)

c/o Nuclear Testing Archive

P.O. Box 98521, M/S 400

Las Vegas, NV 89193-8521

Manager, Northern Nevada FFACO

1 (Uncontrolled, electronic copy)

Public Reading Facility

c/o Nevada State Library \& Archives

100 N Stewart Street

Carson City, NV 89701-4285 